\title{
Wybrane problemy nowoczesnej infrastruktury transportu drogowego
}

pod redakcja

Remigiusza Kozłowskiego 
Remigiusz Kozłowski - Katedra Logistyki, Wydział Zarządzania Uniwersytet Łódzki, 90-237 Łódź, ul. Matejki 22/26

remigiusz@uni.lodz.pl

\author{
RECENZENT \\ Michał Marczak \\ REDAKTOR WYDAWNICTWA UŁ \\ Katarzyna Gorzkowska \\ SKŁAD I ŁAMANIE \\ AGENT PR \\ OKŁADKĘ PROJEKTOWAŁA \\ Barbara Grzejszczak
}

Na okładce wykorzystano ilustrację ze strony www.microsoft.com

(C) Copyright by Uniwersytet Łódzki, 2012

Wydane przez Wydawnictwo Uniwersytetu Łódzkiego

Wydanie I. W.06109.13.0.K

ISBN 978-83-7525-888-2

\author{
Wydawnictwo Uniwersytetu Łódzkiego \\ 90-131 Łódź, ul. Lindleya 8 \\ www.wydawnictwo.uni.lodz.pl \\ e-mail: ksiegarnia@uni.lodz.pl \\ tel. (42) 66558 63, faks (42) 6655862 \\ Druk i oprawa: Quick Druk
}




\section{Spis treści}

Wstęp (Remigiusz Kozłowski) .

1. Transport $\mathbf{i}$ jego infrastruktura $\mathbf{w}$ powiecie tomaszowskim

i opoczyńskim w ocenie turystów (Remigiusz Kozłowski) ...........................

1.1. Rola i znaczenie infrastruktury transportu dla rozwoju regionu łódzkiego...........7

1.2. Atrakcje turystyczne powiatu tomaszowskiego i opoczyńskiego...................

1.3. Działania niezbędne do rozwoju turystyki w powiatach tomaszowskim

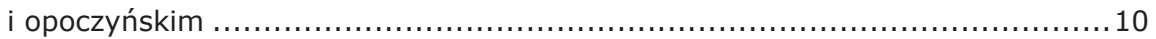

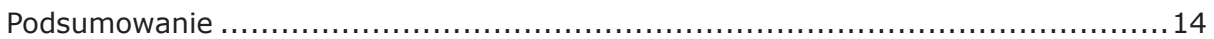

2. Charakterystyka systemu autostrad w Niemczech (Mariusz Wychowaniec) .....17

2.1. Historia, sposób numerowania i podstawowe cechy niemieckich autostrad.......17

2.2. Zasady poruszania się, ograniczenia prędkości i punkty obsługi podróżnych ....22

2.3. Oznakowanie i bezpieczeństwo na autostradach w Niemczech .....................25

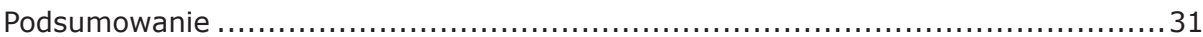

3. System autostrad jako rozwiązanie usprawniające transport

w miastach na podstawie aglomeracji berlińskiej (Michał Głowacki) .............. 33

3.1. Historia rozwoju sieci autostrad w Niemczech oraz w aglomeracji berlińskiej .... 33

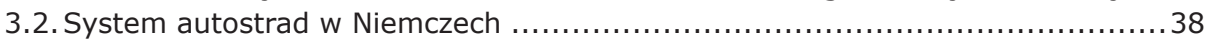

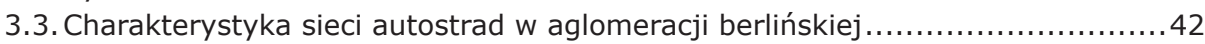

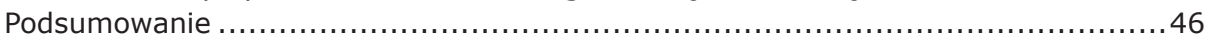

4. Realizacja ciężkiego tranzytu kołowego przez aglomerację łódzką

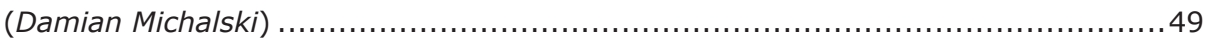

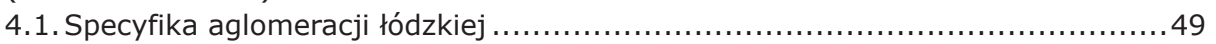

4.2. Aktualny stan tranzytu kołowego przez aglomerację łódzką .......................... 52

4.3. Utrudnienia w przejeździe przez aglomerację łódzką ..............................56

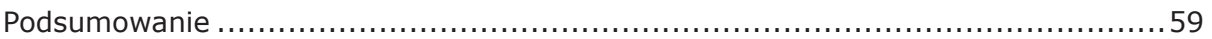

5. Pierścień dróg wokół aglomeracji łódzkiej (Damian Michalski) ...................61

5.1. Plany rozbudowy dróg ekspresowych i autostrad w Polsce .........................61

5.2. System obwodnic wokół aglomeracji łódzkiej ...................................... 64

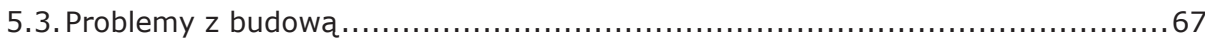

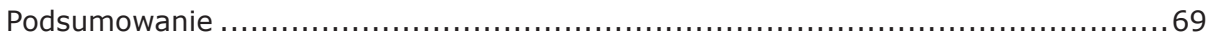

6. Wpływ infrastruktury transportowej na funkcjonowanie C.H. Port Łódź

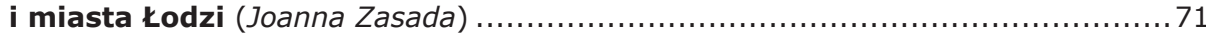

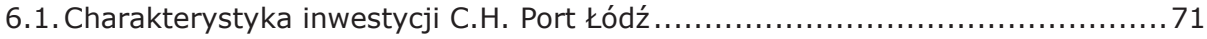

6.2. Zmiany $w$ infrastrukturze transportowej na obszarze otaczającym

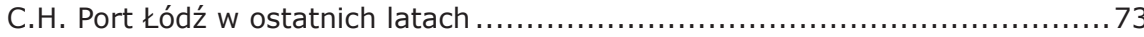

6.3. Efekty rozbudowy infrastruktury drogowej dla analizowanego centrum

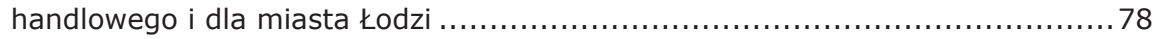

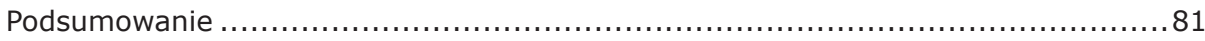


7. Charakterystyka transportu zbiorowego w Łodzi ze szczególnym uwzględnieniem okolic Teatru Wielkiego (Jarosław Wardęcki) ................... 83

7.1. Historia rozwoju transportu miejskiego $\mathrm{w}$ Łodzi ................................. 83

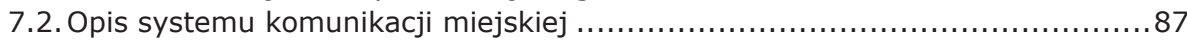

7.3. Charakterystyka systemu transportu miejskiego w okolicach placu

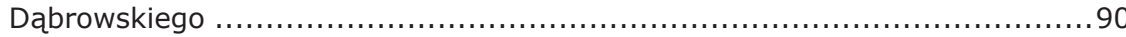

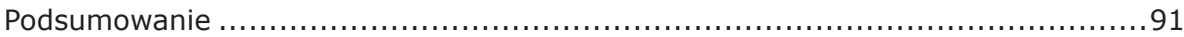

8. Współczesne kierunki ewolucji transportu miejskiego

(Magdalena Maciaszek) ........................................................... 93

8.1. Podział środków transportu miejskiego........................................ 93

8.2. Potrzeby komunikacyjne mieszkańców ośrodków zurbanizowanych ..............97

8.3. Koszty transportu miejskiego.................................................. 100

8.4. Infrastruktura transportu miejskiego ze szczególnym uwzględnieniem

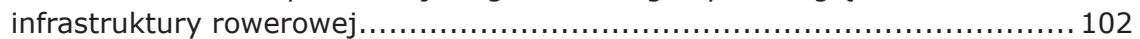

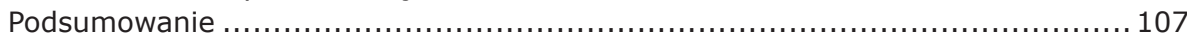

9. Prospołeczne i proekologiczne rozwiązania transportu w Unii

Europejskiej (Magdalena Maciaszek) ............................................ 109

9.1. Polityka Unii Europejskiej w zakresie zrównoważonego transportu .............. 109

9.2. Inicjatywy Unii Europejskiej w zakresie rozwoju zrównoważonego

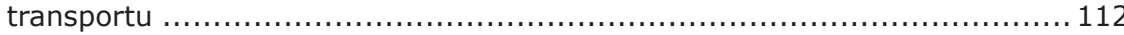

9.3. Prospołeczne i proekologiczne korzyści płynące z wykorzystania roweru ....... 116

9.4. Multimodalne rozwiązania $w$ transporcie miejskim .............................. 120

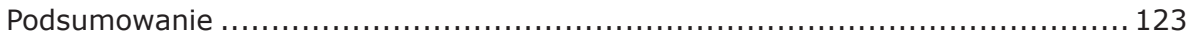

10. „Miasta rowerowe” miastami przyszłości (Magdalena Maciaszek).............. 125

10.1. Rower jako efektywny środek transportu na przykładzie Kopenhagi ............ 125

10.2. Odense - duńskie narodowe miasto rowerzystów............................. 132

10.3. Rozwiązania transportu rowerowego w Holandii ............................. 133

10.4. Innowacyjne rozwiązania w infrastrukturze rowerowej w Holandii .............. 139

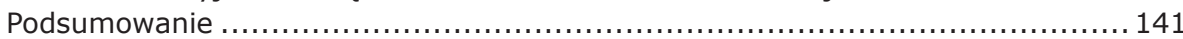

11. Uwarunkowania w zakresie lokalizacji infrastruktury dużych

obiektów sportowych na terenie Łodzi (Adam Majewski) ....................... 143

11.1. Wpływ infrastruktury transportowej na funkcjonowanie miasta i regionu.... 143

11.2. Infrastruktura transportu i inne determinanty lokalizacji ważnych

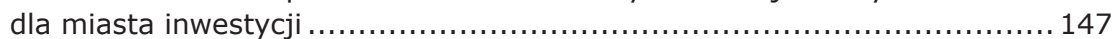

11.3. Charakterystyka infrastruktury transportowej regionu łódzkiego .............. 149

11.4. Lokalizacja obecnie istniejacych obiektów sportowych ........................ 152

11.5. Proponowana lokalizacja dużego przyszłego stadionu ........................ 154

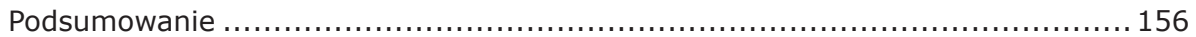

12. Wpływ infrastruktury technicznej na rozwój regionu łódzkiego

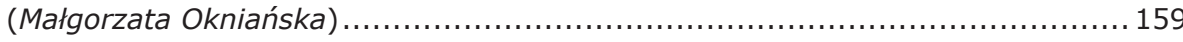

12.1. Wybrane zagadnienia dotyczące drogi S8 na analizowanym terenie ........... 159

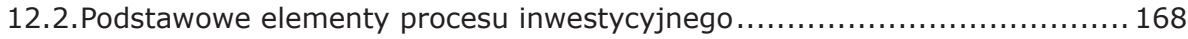

12.3. Bariery rozwoju regionalnego z szerszej perspektywy ....................... 176

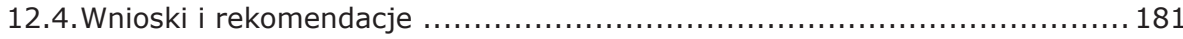

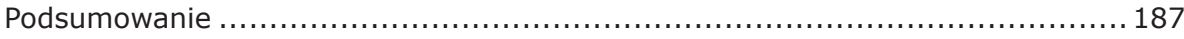

13. Działalność Koła Naukowego „Uni-Logistics” w zakresie rozwoju

infrastruktury logistyki (Łukasz Borowiecki) .................................. 195

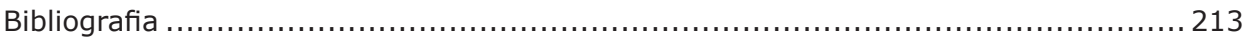

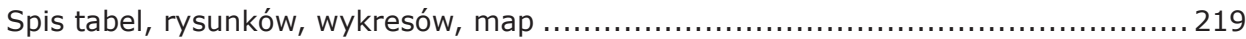




\section{Wstęp}

Niniejsze opracowanie podejmuje szereg problemów z zakresu infrastruktury transportu drogowego. Poruszane są zagadnienia bieżące, ale też są przedstawiane rozwiązania, które moga być wykorzystane w przyszłości.

Pierwszy rozdział podejmuje problem realizacji potrzeb turystyki w zakresie dostępności usług transportowych i jakości oraz kształtu infrastruktury transportu w wybranych dwóch powiatach posiadających rozbudowana bazę turystyczna.

W rozdziale drugim przedstawiony jest system autostrad w Niemczech, uważany za najlepszy w Europie. Kolejny rozdział kontynuuje tematykę infrastruktury drogowej naszych zachodnich sąsiadów. Scharakteryzowano $\mathrm{w}$ nim unikalny na skalę światową system autostrad w aglomeracji berlińskiej.

Kolejne dwa rozdziały podejmuja problematykę tranzytu przez aglomerację łódzką, która leży na przecięciu szlaków transportowych wschódzachód i północ-południe. Aglomeracja ta nie ma obwodnic - sa dopiero budowane lub można użytkować tylko pewne ich fragmenty. Powoduje to wiele problemów zarówno dla podróżujących, jak i mieszkańców.

W rozdziale szóstym przedstawiono bardzo wyraźny przykład zależności pomiędzy infrastrukturą transportu drogowego (w tym przypadku droga ekspresowa) a uruchomieniem dużej inwestycji handlowo-rozrywkowej.

Rozdział siódmy zawiera ciekawą analizę rozwiązań transportu zbiorowego skoncentrowana na wybranym i jednocześnie ważnym fragmencie miasta. Tekst podkreśla znaczenie dobrego zaplanowania infrastruktury transportu i komunikacji miejskiej dla prawidłowego funkcjonowania miasta.

Następne trzy rozdziały poświęcone są proekologicznym rozwiązaniom w transporcie miejskim. Przedstawiono tu m.in. uzasadnienie kosztowe takiego kierunku rozwoju w tym obszarze transportu. Zaprezentowano też politykę Unii Europejskiej, która wspiera proekologiczne rozwiązania $w$ transporcie. Jednym z nich jest wykorzystanie rowerów. W tej części opracowania można również zapoznać się z konkretnymi rozwiązaniami infrastrukturalnymi, które mają zastosowanie w wybranych zagranicznych miastach. 
Rozdział jedenasty podejmuje problematykę lokalizacji dużych obiektów sportowych na terenie Łodzi. Jako główny czynnik decydujący o lokalizacji przyjęto tu kwestię sprawnego dotarcia dużej liczby osób do takiego obiektu oraz możliwość ich szybkiego, bezpiecznego wydostania się i powrotu do domów. W takim przypadku najważniejszą rolę pełni infrastruktura transportu.

W kolejnym rozdziale w kompleksowy i interesujący sposób przedstawiono zagadnienie bardzo ważnej dla regionu łódzkiego trasy S8. Autorka profesjonalnie i jednocześnie przystępnie opisała skomplikowane elementy procesu inwestycyjnego, którego celem jest zbudowanie drogi ekspresowej. Tekst zawiera niezwykle istotny podrozdział identyfikujący bariery rozwoju regionu łódzkiego oraz wnioski i rekomendacje umożliwiające zniwelowanie zidentyfikowanych barier.

Ostatni rozdział został poświęcony działalności Koła Naukowego Logistyki "Uni-Logistics". Organizacja ta aktywnie działa i od kilku lat zajmuje się badaniami oraz propagowaniem wiedzy, m.in. z zakresu infrastruktury logistyki.

Przedstawiony stan zaawansowania budowy infrastruktury transportu drogowego jest aktualny na sierpień 2012 r. 


\section{Transport i jego infrastruktura w powiecie tomaszowskim i opoczyńskim w ocenie turystów}

Remigiusz Kozłowski*

\subsection{Rola i znaczenie infrastruktury transportu dla rozwoju regionu łódzkiego}

Od wieków wiadomo, że drogi zapewniaja dostępność do terenów, przez które przebiegają. Ma to bardzo duże znaczenie dla generowania rozwoju gospodarczego, w tym także dla rozwoju turystyki ${ }^{1}$. Ogromne znaczenie ma rozmieszczenie elementów infrastruktury transportu. Zapewnienie tego optymalnego rozmieszczenia powoduje szereg korzystnych zjawisk, do których zaliczamy m.in.: podniesienie atrakcyjności inwestycyjnej i turystycznej² danego obszaru, zapobieganie powstawaniu kongestii oraz zmniejszenie negatywnego wpływu na środowisko naturalne. Dzięki właściwemu zaprojektowaniu i wybudowaniu infrastruktury transportu następuje lepsze wykorzystanie czasu ludzi, którzy - zamiast siedzieć w samochodach stojących w korkach lub poruszajacych się niezwykle wolno - moga np. wypoczywać lub pracować.

Celem rozdziału jest analiza wyników badania zadowolenia i oceny infrastruktury transportu przez turystów, którzy odwiedzili powiat tomaszowski i opoczyński. Zamieszczono także wnioski i sugestie dotyczace kierunków działań samorządów i innych organizacji, zmierzających do wybudowania brakujacych elementów infrastruktury transportu.

* Prof. nadzw. dr hab. inż. Remigiusz Kozłowski - Katedra Logistyki, Wydział Zarządzania Uniwersytetu Łódzkiego, ul. Matejki 22/26, 90-237 Łódź.

${ }^{1} \mathrm{~K}$. Parzych, Ocena zróżnicowania atrakcyjności przestrzeni turystycznej województwa kujawsko-pomorskiego, [w:] R. Muszkieta, W. Żukow, M. Napierała i E. Saks (red.), Stan i rozwój regionalnego sportu i rekreacji, Ośrodek Rekreacji, Sportu i Edukacji w Poznaniu, Poznań 2010, s. 110.

${ }^{2}$ A. Wolaniuk, Koncepcja centrum wypoczynkowo-edukacyjnego Polski środkowowschodniej - powiaty tomaszowski, opoczyński wraz z regionem świętokrzyskim, [w:] R. Kozłowski (red.), Strategiczne znaczenie dróg ekspresowych dla rozwoju Polski środkowo-wschodniej, wyd. 2 popr. i rozszerz., Wyd. Uniwersytetu Łódzkiego, Łódź 2010, s. $13-14$. 


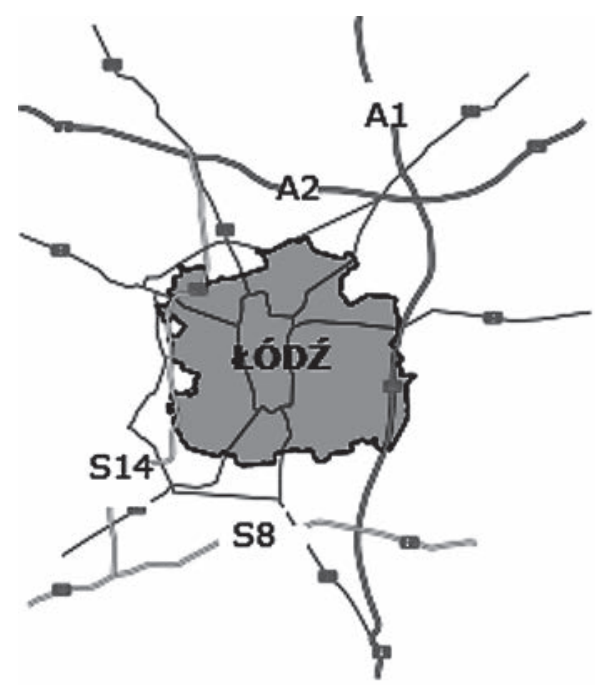

Mapa 1. Aktualny układ dróg Polsce środkowej

Źródło: opracowanie - Anna Zmysłowska

Województwo łódzkie ma niezwykle dogodne położenie pod względem komunikacyjnym - przebiegać tędy będą najważniejsze drogi krajowe (mapa 1) oraz linie kolejowe. Zatem dojazd do regionu łódzkiego z innych części Polski oraz Europy będzie ułatwiony. Uzupełniająca sieć dróg wojewódzkich, powiatowych i gminnych pełni także istotną funkcję zapewnienia dostępności do miejscowości mających znaczenie turystyczne.

\subsection{Atrakcje turystyczne powiatu tomaszowskiego i opoczyńskiego}

Podejmując temat infrastruktury transportu w kontekście turystyki, nie sposób pominąc jej elementów, które jednocześnie stanowią atrakcje turystyczne. Chodzi o ścieżki rowerowe i ciagi pieszo-rowerowe. $\mathrm{Na}$ terenie miast pełnią one najczęściej funkcje zmniejszania uciążliwości transportu kołowego dla środowiska naturalnego oraz polepszania kondycji fizycznej mieszkańców cierpiących na chroniczny brak ruchu. Natomiast poza terenami zurbanizowanymi moga stanowić atrakcje przyciągajace turystów. Z tych powodów należy zawsze, planując inwestycje drogowe, dokładnie przeanalizować, czy nie istnieje możliwość wybudowania przy tej okazji ciaggów rowerowych lub pieszo-rowerowych. 
Obecnie we wszystkich cywilizowanych krajach świata coraz częściej stosuje się właśnie takie rozwiązania, a do niekwestionowanych liderów należą kraje Unii Europejskiej.

Województwo łódzkie posiada dużą różnorodność atrakcji turystycznych, dzięki czemu okres przebywania turystów na tym terenie może być znacznie dłuższy niż w innych rejonach. W efekcie wykorzystanie dróg i innych elementów infrastruktury transportu może być tu znacznie większe. Ma to ogromne znaczenie dla ekonomiki budowy i eksploatacji dróg - po prostu poniesione tutaj nakłady będą się szybciej zwracały. Jest to bardzo ważny argument przemawiający z budową elementów infrastruktury transportu, służących m.in. celom turystycznym.

W tab. 1 zostały zamieszczone atrakcje turystyczne znajdujące się na terenie powiatu opoczyńskiego i tomaszowskiego. Każdej z nich została nadana ranga: lokalna, regionalna, krajowa lub światowa. Rangę lokalną przyznano pięciu obiektom, z czego cztery znajdują się na terenie powiatu opoczyńskiego, a jedna tomaszowskiego. Atrakcję regionalną stanowią: kościół romański w Żarnowie, bunkry Anlage Mitte w Jeleniu oraz Ośrodek Hodowli Żubrów w Smardzewicach-Książu. Z kolei atrakcji o randze krajowej jest aż sześć. Do nich zaliczono kościół romański św. Idziego w Inowłodzu, bunkier wraz z trasa turystyczną w Konewce, rezerwat Niebieskie Źródła w Tomaszowie Mazowieckim, Skansen Rzeki Pilicy w Tomaszowie Mazowieckim, miejscowość Spała oraz szlak wodny rzeki Pilicy.

Tabela 1. Wykaz atrakcji turystycznych analizowanych powiatów

\begin{tabular}{|c|l|l|l|c|c|c|c|}
\hline Lp. & \multicolumn{1}{|c|}{ Powiat } & Miejscowość & Atrakcje & $\begin{array}{c}\text { Ranga } \\
\text { światowa }\end{array}$ & $\begin{array}{c}\text { Ranga } \\
\text { krajowa }\end{array}$ & $\begin{array}{c}\text { Ranga } \\
\text { regionalna }\end{array}$ & $\begin{array}{c}\text { Ranga } \\
\text { lokalna }\end{array}$ \\
\hline 72. & opoczyński & Białczów & pałac i park & & & & 3 \\
\hline 73. & opoczyński & Drzewica & zamek & & & & 3 \\
\hline 74. & opoczyński & Klew & $\begin{array}{l}\text { rezerwat Diabla } \\
\text { Góra }\end{array}$ & & & & 3 \\
\hline 75. & opoczyński & Żarnów & $\begin{array}{l}\text { grodzisko } \\
\text { Szwedzka Góra }\end{array}$ & & & & 3 \\
\hline 76. & opoczyński & Żarnów & $\begin{array}{l}\text { kościół } \\
\text { romański }\end{array}$ & & & & \\
\hline 124. & rzecki & - & $\begin{array}{l}\text { szlak wodny } \\
\text { rzeki Pilicy }\end{array}$ & & 1 & & \\
\hline 142. & tomaszowski & Inowłódz & $\begin{array}{l}\text { kościół romań- } \\
\text { ski św. Idziego }\end{array}$ & & 1 & & \\
\hline
\end{tabular}


Tab. 1 (cd.)

\begin{tabular}{|c|l|l|l|c|c|c|c|}
\hline Lp. & \multicolumn{1}{|c|}{ Powiat } & Miejscowość & \multicolumn{1}{|c|}{ Atrakcje } & $\begin{array}{c}\text { Ranga } \\
\text { światowa }\end{array}$ & $\begin{array}{c}\text { Ranga } \\
\text { krajowa }\end{array}$ & $\begin{array}{c}\text { Ranga } \\
\text { regionalna }\end{array}$ & $\begin{array}{c}\text { Ranga } \\
\text { lokalna }\end{array}$ \\
\hline 143. & tomaszowski & Jeleń & $\begin{array}{l}\text { bunkry Anlage } \\
\text { Mitte }\end{array}$ & & 2 & \\
\hline 144. & tomaszowski & Konewka & $\begin{array}{l}\text { bunkier - trasa } \\
\text { turystyczna }\end{array}$ & & 1 & & \\
\hline 145. & tomaszowski & $\begin{array}{l}\text { Smardze- } \\
\text { wice-Ksiaż }\end{array}$ & $\begin{array}{l}\text { Ośrodek Ho- } \\
\text { dowli Żubrów }\end{array}$ & & & & \\
\hline 146. & tomaszowski & Spała & miejscowość & & 1 & & \\
\hline 147. & tomaszowski & $\begin{array}{l}\text { Tomaszów } \\
\text { Mazowiecki }\end{array}$ & $\begin{array}{l}\text { rezerwat Nie- } \\
\text { bieskie Źródła }\end{array}$ & & 1 & & \\
\hline 148. & tomaszowski & $\begin{array}{l}\text { Tomaszów } \\
\text { Mazowiecki }\end{array}$ & $\begin{array}{l}\text { Skansen Rzeki } \\
\text { Pilicy }\end{array}$ & & & & \\
\hline 149. & tomaszowski & Ujazd & miejscowość & & & & \\
\hline
\end{tabular}

Źródło: K. Borkowski, T. Grabiński, R. Seweryn, A. Wilkowska, L. Mazanek, Ruch turystyczny w województwie łódzkim w 2008 r. Raport końcowy, Kraków 2009, s. 13-18 (fragmenty tab. 1.4).

\subsection{Działania niezbędne do rozwoju turystyki w powiatach tomaszowskim i opoczyńskim}

Badania ruchu turystycznego w województwie łódzkim w 2008 r., przeprowadzone przez ekspertów z Uniwersytetu Ekonomicznego w Krakowie, Akademii Wychowania Fizycznego w Krakowie oraz Wyższej Szkoły Turystyki i Ekologii w Suchej Beskidzkiej, zawieraja szereg interesujacych danych. Ich autorzy przedstawili m.in., w jaki sposób turyści dotarli do szeregu atrakcji znajdujących się na terenie województwa łódzkiego (dane te zawiera tab. 2). W badaniach wyodrębniono środki transportu, takie jak: samochód, samolot, autobus, bus i pociąg. Autorzy tych analiz dokonali także podziału na środki transportu zbiorowego kursujace regularnie (samolot rejsowy, autobus linii regularnej) i organizowane dla indywidualnych potrzeb (np. autokar turystyczny). Wyniki uwzględniają też podział turystów na krajowych i zagranicznych. 
Tabela 2. Struktura wykorzystywanych przez turystów środków transportu, którymi przyjechali do atrakcji turystycznych w województwie łódzkim (w \%)

\begin{tabular}{|l|c|c|}
\hline \multicolumn{1}{|c|}{ Środek transportu } & Krajowi & Zagraniczni \\
\hline Samochód & 74 & 64 \\
\hline Samolot (ogółem) & 0 & 36 \\
\hline Samolot rejsowy & 0 & 28 \\
\hline Samolot tanich linii lotniczych & 0 & 8 \\
\hline Pociąg & 7 & 3 \\
\hline Autobus linii regularnej & 6 & 5 \\
\hline Bus & 4 & 9 \\
\hline Autokar turystyczny & 7 & 1 \\
\hline Inny & 4 & 1 \\
\hline
\end{tabular}

Źródło: jak do tab. 1, s. 48.

Zdecydowanie najwięcej turystów przyjechało do województwa łódzkiego samochodem osobowym. W przypadku osób przemieszczajacych się $z$ innych regionów Polski było to aż 74\%. Zaskakujący jest fakt, że aż 64\% turystów zagranicznych przyjechało do regionu łódzkiego samochodami.

Transport lotniczy ma duże znaczenie dla gości zagranicznych, którzy skorzystali z tej gałęzi transportu (36\% przybywających w celach turystycznych do województwa łódzkiego). Co ciekawe, stosunkowo niewielu z nich skorzystało z oferty tanich przewoźników (tylko $8 \%$ ) - zdecydowanie dominowały tu linie regularne oferowane przez operatorów lotniczych. Dla turystów krajowych transport lotniczy nie istniał.

Transport kolejowy także odpowiadał turystom, zarówno krajowym, jak i zagranicznym. Zdecydowanie częściej korzystali z tej gałęzi transportu turyści krajowi (7\%) niż zagraniczni (3\%).

Turyści wykorzystywali także autobusowa komunikację zbiorową. Osoby z innych regionów Polski przyjeżdżały przede wszystkim autokarami turystycznymi (7\%) i regularnie kursujacymi autobusami $(6 \%)$. Zdecydowanie rzadziej korzystano z busów (tylko 4\%). Z kolei turyści zagraniczni preferowali $w$ tej kategorii środków transportu busy - aż 9\%. Stosunkowo często używali także regularnych linii autobusowych (5\%). Goście z zagranicy bardzo rzadko jeździli indywidualnie zamawianymi autokarami turystycznymi - tylko $1 \%$.

Autorzy badań zapytali o inne, niewymienione wyżej środki transportu, wykorzystywane przez turystów w celu dojechania do atrakcji turystycznych w regionie łódzkim. W tej kategorii mieszczą się m.in. motory, 
motorowery, rowery i turystyka piesza. Turyści krajowi korzystali z tych środków transportu dość rzadko (4\%), a zagraniczni bardzo rzadko (1\%).

Przytoczone badania zawieraja także informacje nt. oceny dojazdu do miejsca, w którym znajdowały się atrakcje turystyczne oraz opinie o transporcie lokalnym (dane te przedstawia tab. 3).

Tabela 3. Opinia turystów na temat dojazdu do miejscowości oraz transportu lokalnego

\begin{tabular}{|l|c|c|c|c|c|c|}
\hline \multicolumn{1}{|c|}{ Ocena } & $\begin{array}{c}\text { Bardzo } \\
\text { dobra }\end{array}$ & Dobra & $\begin{array}{c}\text { Może } \\
\text { być }\end{array}$ & Źle & $\begin{array}{c}\text { Bardzo } \\
\text { źle }\end{array}$ & $\begin{array}{c}\text { Brak } \\
\text { oceny }\end{array}$ \\
\hline \multicolumn{7}{|c|}{ Opinia gości zagranicznych (w \%) } \\
\hline $\begin{array}{l}\text { Dojazd } \\
\text { do miejscowości }\end{array}$ & 11 & 23 & 17 & 19 & 12 & 8 \\
\hline Transport lokalny & 3 & 11 & 14 & 16 & 4 & 52 \\
\hline \multicolumn{7}{|c|}{ Opinia gości krajowych (w \%) } \\
\hline $\begin{array}{l}\text { Dojazd } \\
\text { do miejscowości }\end{array}$ & 13 & 38 & 24 & 10 & 4 & 11 \\
\hline Transport lokalny & 1 & 9 & 16 & 9 & 3 & 62 \\
\hline
\end{tabular}

Źródło: jak do tab. 1, s. 65 i 68 (fragmenty tabel).

Analizując tab. 3, widać, że turyści zagraniczni są bardziej krytyczni od krajowych. W każdym razie dojazd do atrakcji w regionie łódzkim powinien być oceniany przez zdecydowaną większość odwiedzających dobrze lub bardzo dobrze - a tak, niestety, nie jest.

W przypadku transportu lokalnego oceny były zdecydowanie bardziej krytyczne. Bardzo dobrze oceniło go zaledwie 1\% turystów krajowych i 3\% zagranicznych. Dobrą ocenę transportowi lokalnemu wystawiło tylko $9 \%$ odwiedzających z innych regionów Polski i $11 \%$ zagranicznych. Ciekawostką jest to, że transport lokalny został lepiej oceniony przez turystów zagranicznych niż krajowych, a w przypadku dojazdu do miejscowości było odwrotnie.

Autorzy powoływanych badań zebrali także opinie na temat wysokości cen za usługi transportu lokalnego, co przedstawia tab. 4.

Tabela 4. Opinie o cenach transportu lokalnego ( $w \%$ )

\begin{tabular}{|l|c|c|c|c|c|}
\hline \multicolumn{1}{|c|}{ Usługa } & Turyści & $\begin{array}{c}\text { Cena } \\
\text { wysoka }\end{array}$ & $\begin{array}{c}\text { Cena od- } \\
\text { powiednia }\end{array}$ & Cena niska & Brak oceny \\
\hline $\begin{array}{l}\text { Transport } \\
\text { lokalny }\end{array}$ & krajowi & 9 & 22 & 3 & 66 \\
\cline { 2 - 6 } & zagraniczni & 8 & 22 & 14 & 57 \\
\hline
\end{tabular}

Źródło: jak do tab. 1, s. 74. 
Większość respondentów wskazała, że ceny transportu lokalnego są odpowiednie. Najprawdopodobniej turyści, którzy nie korzystali z tego rodzaju transportu, nie zamieścili oceny. Jeśli przyją́ taką hipotezę, to turyści zagraniczni częściej korzystali z transportu lokalnego.

Na szczególną uwagę zasługują wyniki badań w zakresie negatywnych aspektów pobytu turystów w województwie łódzkim. Zostały one zamieszczone w tab. 5.

Tabela 5. Negatywne aspekty pobytu

\begin{tabular}{|l|c|c|c|}
\hline \multirow{2}{*}{ Aspekt } & \multicolumn{2}{c|}{ Odwiedzający - udział w \% } & \multirow{2}{*}{$\begin{array}{c}\text { Pozycja } \\
\text { w rankingu }\end{array}$} \\
\cline { 2 - 3 } & krajowi & zagraniczni & 1 \\
\hline Korki, remonty ulic, objazdy & 16,7 & 16,1 & 2 \\
\hline Nic & 6,4 & 4,9 & \\
\hline $\begin{array}{l}\text { Brak infrastruktury } \\
\text { (budki telefoniczne, Internet, toalety, } \\
\text { informacja turystyczna itp.) }\end{array}$ & 5,3 & 3,4 & 3 \\
\hline $\begin{array}{l}\text { Dostępność (oznakowanie, porozumie- } \\
\text { wanie się, dojazd) }\end{array}$ & 4,9 & 6,0 & 4 \\
\hline
\end{tabular}

Źródło: jak do tab. 1, s. 74 (fragment tabeli).

Okazało się, że na 15 czynników wyodrębnionych przez autorów badania, w czołówce znalazły się trzy powiązane z transportem i jego infrastruktura. Na pierwszym miejscu, z dużą przewaga nad kolejnym czynnikiem, turyści zarówno krajowi, jak i zagraniczni wskazali utrudnienia w poruszaniu się po regionie, tj. korki na drogach, remonty ulic i związane z nimi objazdy.

Na drugim miejscu według krajowych turystów znalazły się braki w infrastrukturze, do których - oprócz ściśle związanych z turystką, np. informacji turystycznej - zaliczyli media umożliwiające komunikację (sieci telekomunikacyjne do przesyłania połączeń głosowych i danych). Natomiast turyści zagraniczni na drugiej pozycji pod względem negatywnych aspektów pobytu umieścili dostępność (w tym m.in. dojazd).

Aby wykorzystać potencjał turystyczny tkwiący w województwie łódzkim, niezbędna jest budowa nowych dróg i modernizacja już istniejących. Samorządy naszego regionu należą do liderów w tym obszarze w Polsce. Buduje się lub modernizuje wiele dróg wojewódzkich, powiatowych i gminnych. Jednak to dopiero początek długiego procesu, którego celem jest zapewnienie infrastruktury wystarczającej dla potrzeb m.in. turystyki. Dla wielu miejsc ich słaba dostępność komunikacyjna 
stanowi jedną z głównych barier rozwoju "przemysłu turystycznego". Można do nich zaliczyć m.in. tereny powiatu tomaszowskiego i opoczyńskiego. Są one niewystarczająco skomunikowane z aglomeracja łódzką, w której mieszkaja konsumenci usług turystycznych. W efekcie mieszkańcy tej aglomeracji często wybierają inne miejsca wypoczynku, zlokalizowane np. w województwie kujawsko-pomorskim, gdzie łatwiej jest dojechać. Skutkiem tego są niższe obroty i mniejsze zatrudnienie $\mathrm{w}$ przedsiębiorstwach sektora turystycznego działających na terenie wymienionych powiatów. W przytoczonym przykładzie jedynym rozwiązaniem poprawiajacym skomunikowanie powiatu tomaszowskiego i opoczyńskiego z aglomeracją łódzką jest zbudowanie drogi ekspresowej S74 w przebiegu przez Tomaszów Mazowiecki i węzeł Łódź-Południe.

Wszystkie problemy rozwoju turystyki związane z brakującymi elementami infrastruktury transportu można rozwiązać. Będzie to wymagać zaangażowania samorządów oraz wytrwałości w niezwykle długotrwałych działaniach zwiazanych z planowaniem i budowa tej infrastruktury.

Dotychczasowe działania wielu przedstawicieli samorządów województwa łódzkiego napawaja optymizmem. Na terenie naszego regionu prężnie działa największe w Polsce "Stowarzyszenie jednostek samorządu terytorialnego na rzecz budowy dróg ekspresowych S-8 (przez Sieradz-Łódź) i S-14". W trakcie dyskusji o drodze S8 odbyło się wiele konferencji z udziałem dużej liczby środowisk. Godnym podkreślenia wydarzeniem mającym doprowadzić do rozwoju województwa łódzkiego stała się także konferencja pt. „Drogi ekspresowe S-74, S-12 i S-8 (Wrocław-Łódź) i ich strategiczne znaczenie dla rozwoju Polski środkowo-wschodniej", która odbyła się 4 czerwca 2008 r. z udziałem ministra infrastruktury Cezarego Grabarczyka. Skupiła ona wiele różnych środowisk mających wspólny cel.

\section{Podsumowanie}

W wyniku przeprowadzonych analiz można stwierdzić, że obecnie transport drogowy odgrywa największą rolę w umożliwianiu przyjazdu turystów do powiatów tomaszowskiego i opoczyńskiego. Zdecydowanie najwięcej odwiedzających przyjechało samochodami. Autobusowa komunikacja zbiorowa także była wykorzystywana przez turystów. 
Ocena dojazdu transportem drogowym do atrakcji turystycznych wyraźnie wskazuje na konieczność jej poprawy - może to nastapić tylko i wyłącznie poprzez rozbudowę infrastruktury. Zwiększenie liczby turystów, zwłaszcza z zagranicy, będzie również wymagać m.in. większej liczby połączeń lotniczych na Lotnisku im. S. Reymonta w Łodzi.

Z przedstawionych badań wynika, że turyści zarówno krajowi, jak i zagraniczni nie sa zadowoleni $z$ transportu - w tym obszarze trzeba podjać szereg działań, leżących również w gestii samorządów. Wśród negatywnych aspektów pobytu turystów w regionie łódzkim najwyższe noty otrzymały właśnie kwestie związane z transportem i jego infrastruktura.

W końcu 2011 r. pojawiła się duża szansa na dobre skomunikowanie drogowe analizowanych powiatów z aglomeracją łódzką w wyniku decyzji Komisji Europejskiej, która rozszerzyła listę korytarzy TEN-T. Możliwe jest teraz zbudowanie drogi w parametrach drogi ekspresowej łączącej węzeł drogowy Łódź-Południe (A1/S8) z drogą S8 w okolicach Tomaszowa Mazowieckiego (mapa 2).

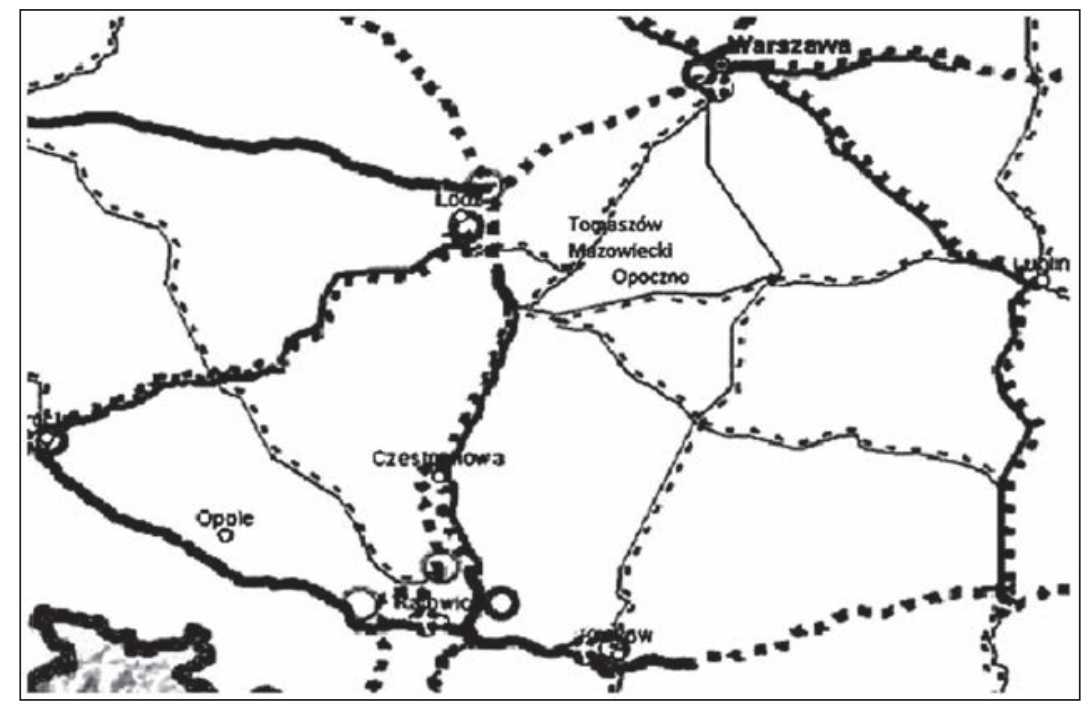

Mapa 2. Znowelizowana sieć TEN-T w Polsce środkowej

Źródło: opracowanie - Anna Palczewska na podstawie: http://ec.europa.eu/ transport/infrastructure/doc/com(2011)_650_final_2_annex_i_part15.pdf [z dn. 14.07.2012] 
W świetle przedstawionych badań transport kolejowy był także wykorzystywany. W tym przypadku bariera rozwoju jest oferta przewozowa spółek kolejowych. Ostatnie zmiany na kolei daja nadzieję, że dostrzeżony zostanie potencjał terenów powiatu opoczyńskiego i tomaszowskiego jako źródła klientów i z tego względu przejazdy pociągów będa dopasowane do potrzeb ruchu turystycznego.

${ }^{3}$ Nadzieję taką daje m.in. fakt, że 15 lutego 2011 r. na wspólnej konferencji prasowej przedstawicie wszystkich spółek kolejowych zaprezentowali nowy rozkład jazdy pociągów - kilka miesięcy wcześniej brak synchronizacji działań tych spółek doprowadził do wielu problemów w transporcie pasażerskim w całej Polsce. 


\title{
2. Charakterystyka systemu autostrad w Niemczech
}

\author{
Mariusz Wychowaniec*
}

\subsection{Historia, sposób numerowania i podstawowe cechy niemieckich autostrad}

Niemcy, kraj sąsiedzki, jest pod wieloma względami podobny do Polski, ale również jakże inny. Inna kultura, inne ukształtowanie geograficzne, inna mentalność, lepsi piłkarze (których zresztą część urodziła się w Polsce). Jednak aspekt, który dla autora jest najważniejszy i na którym się skupił, to przede wszystkim inna, lepsza i gęstsza sieć drogowa.

O niemieckich drogach nikt chyba nie jest w stanie wyrazić złej opinii. Cały system drogowy jest jednym z lepszych i efektywniejszych nie tylko w Europie, ale również na całym świecie. Praktycznie całe Niemcy pokryte są drogami ekspresowymi i autostradami - fakt, którego bardzo możemy pozazdrościć. Sieć ta jest wyraźnie twardsza, ale - jak twierdzą eksperci - łatwiejsza w utrzymaniu.

Podróż po niemieckich autostradach to na pewno niezapomniane doświadczenie. Większość kierowców świata słyszała o nich i chciałaby się z nimi zmierzyć. Jednak niektórzy sa rozczarowani po pierwszym zetknięciu z tamtejszymi autostradami. Przyjeżdżaja do Niemiec z wizja 12-pasmowej "superdrogi”, gdzie samochody widoczne są tylko przez chwilę podczas manewru mijania. W rzeczywistości te "superdrogi" podobne są do typowych autostrad i pomimo różnych plotek, nie wszyscy przemykaja po nich z szybkościa zbliżona do szybkości dźwięku. Historie o braku ograniczeń prędkości są tylko częściowo prawdziwe, wiele odcinków je posiada. Niezaprzeczalne sa jednak fakty, że drogi te sa świetnie zaprojektowane, zbudowane i użytkowane nawet na wschodzie, gdzie niemiecki rząd musiał poradzić sobie po 40-letnim okresie komunizmu. Liczne udogodnienia i dobrze

* Mgr Mariusz Wychowaniec - Katedra Logistyki, Wydział Zarządzania Uniwersytetu Łódzkiego, ul. Matejki 22/26, 90-237 Łódź. 
wyszkoleni, pomagający sobie nawzajem kierowcy, to rzeczywistość, do której każdy chciałby dążyć ${ }^{1}$.

Ogólne statystyki sieci drogowej przedstawiaja się bardzo ciekawie ${ }^{2}$. Całkowita jej długość wynosi 231359 km. Autostrady (niem. Autobahnen) to $12531 \mathrm{~km}$. Drogi związkowe (niem. Bundesstraßen) licza sobie $40711 \mathrm{~km}$. Długość dróg krajowych (niem. Landstraßen) wynosi 86597 km, a dróg okręgowych (niem. Kreisstraßen) 91520 km.

Krótka historię powstawania autostrad w Niemczech przedstawia się następująco. Pierwsza autostrada na świecie powstała w Berlinie pomiędzy rokiem 1913 a 1921, od razu zdobywając sobie ogromny szacunek użytkowników. 19-kilometrowa AVUS (niem. Automobil-Verkehrs- und Übungsstraße) w południowo-zachodnim Berlinie była autostrada eksperymentalna, służącą czasami nawet dzisiaj do wyścigów. Cechowały ja dwa ośmiometrowe pasy ruchu oddzielone dziewięciometrowym pasem zieleni.

Kiedy Włosi wybudowali kilka autostrad w 1920 r., Niemcy nie chcieli zostać w tyle i otworzyli swoje pierwsze "drogi tylko dla samochodów" (bo tak poczatkowo nazywano te drogi; nazwa Autobahn, czyli autostrada, powstała dopiero w 1929 r.) , w 1929 r. łączące Dusseldorf i Opladen, a w 1932 r. łączące Kolonię i Bonn. We wczesnych latach 30. XX wieku Hitler, dostrzegając potencjał propagandowy sieci szybkich dróg, zainicjował program mający na celu połączenie autostradami północ z południem oraz zachód ze wschodem. Pierwsza z nich, łącząca Frankfurt i Darmstadt, została otwarta 19 maja 1935 r. Pod koniec II wojny światowej system autostrad liczył już 2128 km. Budowa nowych odcinków była kontynuowana po wojnie, w 1953 r., dodając 144 km przed rokiem 1958, co łącznie stanowiło 2272 km. Począwszy od roku 1959, RFN podjęła się realizacji serii planów czteroletnich dotyczących rozbudowy sieci autostrad. Dzięki temu jej całkowita długość stale rosła, osiagając 3076 km w 1964 r., 4110 w 1970 r., 5258 w 1973 r., 6207 w 1976 r., 7029 w 1979 r. i 9080 km w 1984 r.

Nowe plany, tym razem pięcioletnie, zakładały dostęp do autostrad w odległości $10 \mathrm{~km}$ z dowolnego punktu Niemiec, co zaowocowało całkowitą ich długością 8800 km w 1990 r. Plany te zostały jednak wstrzymane w 1990 r., kiedy to nastapiło zjednoczenie Niemiec, a władze kraju skupiły się na udoskonaleniu dróg "odziedziczonych" po NRD. Przyłączenie dróg z Niemiec Wschodnich doprowadziło do wzrostu długości systemu autostrad do ok. 11000 km w 1992 r. Natomiast rozbudowa połączonej

\footnotetext{
${ }^{1}$ www.gettingaroundgermany.info/autobahn.htm [z dn. 28.10.2011].

2 http://deutschland.de/aufeinenblick/uebersicht.php?lang $=2$ [z dn. 28.10.2011].
} 
sieci przyczyniła się do osiągnięcia 11712 km w 2001 r. i 12044 w 2004 r. Wszystko to sprawia, że niemiecka sieć autostrad jest trzecia, po systemie autostrad Stanów Zjednoczonych i Chin, największą siecią na świecie³.

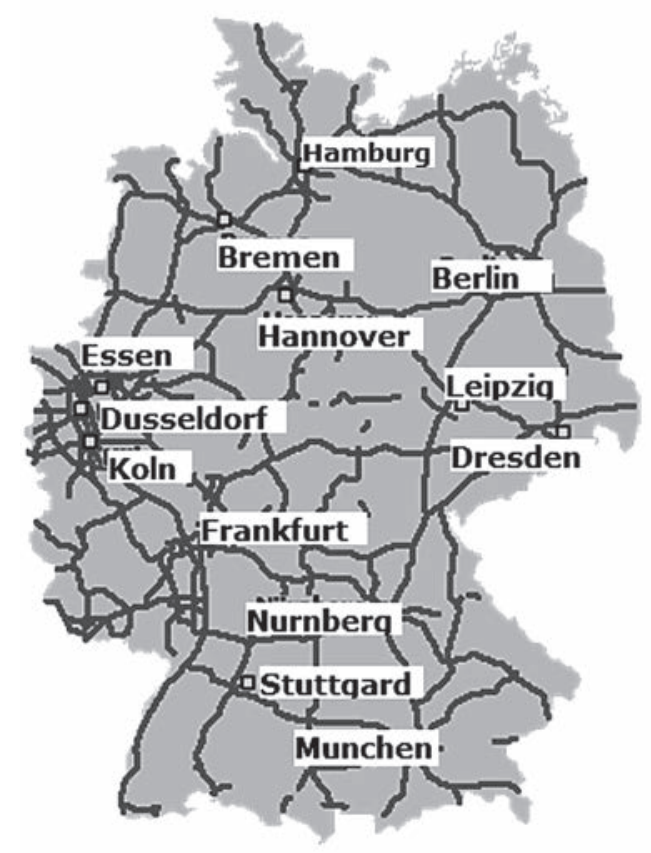

Rysunek 1. Aktualna sieć niemieckich autostrad

Źródło: opracowanie - Anna Zmysłowska

Aktualny system numerowania autostrad został wprowadzony w Niemczech w 1974 r. Nazwa każdej z autostrad, tak jak w Polsce, składa się z wielkiej litery "A" (będącej skrótem od niemieckiego wyrazu Autobahn), po której jest odstęp, i numeru, przykładowo A 6. Główne autostrady, przebiegajace przez całe Niemcy, maja jednocyfrowy numer. Krótsze autostrady, odgrywające przede wszystkim duże role regionalne (np. łączące dwa duże miasta lub regiony na terenie kraju), maja numer dwucyfrowy, przykładowo A 24 pomiędzy Berlinem i Hamburgiem. Numeracja wygląda następująco4:

- od A 10 do A 19 - Niemcy Wschodnie (Berlin, Saksonia-Anhalt, część Saksonii i Brandenburgii),

\footnotetext{
${ }^{3}$ www.gettingaroundgermany.info/autobahn.htm [z dn. 28.10.2011].

${ }^{4}$ http://en.wikipedia.org/wiki/German_Autobahnen [z dn. 28.10.2011].
} 
- od A 20 do A 29 - Niemcy Północne i Północno-wschodnie,

- od A 30 do A 39 - Niemcy Północno-zachodnie (Dolna Saksonia),

- od A 40 do A 49 - okolice Zagłębia Ruhry,

- od A 50 do A 59 - również okolice Zagłębia Ruhry,

- od A 60 do A 69 - Nadrenia-Palatynat, Saara i Hesja,

- od A 70 do A 79 - Turyngia, północna Bawaria i część Saksonii,

- od A 80 do A 89 - Badenia-Wirtembergia,

- od A 90 do A 99 - południowa Bawaria.

Występują też bardzo krótkie autostrady o znaczeniu lokalnym. Przykładem może być np. A 555 z Kolonii do Bonn. Są one zazwyczaj znakowane trzema numerami, z których pierwszy zależy (podobnie jak w przypadkach opisanych powyżej) od regionu. Autostrady z zachodu na wschód maja numery parzyste, a z północy na południe - numery nieparzyste. Północno-południowe odcinki są numerowane z zachodu na wschód, czyli im bardziej na wschód, tym większy numer; natomiast odcinki zachodnio-wschodnie numerowane są z północy (niższe numery) na południe (wyższe numery) ${ }^{5}$.

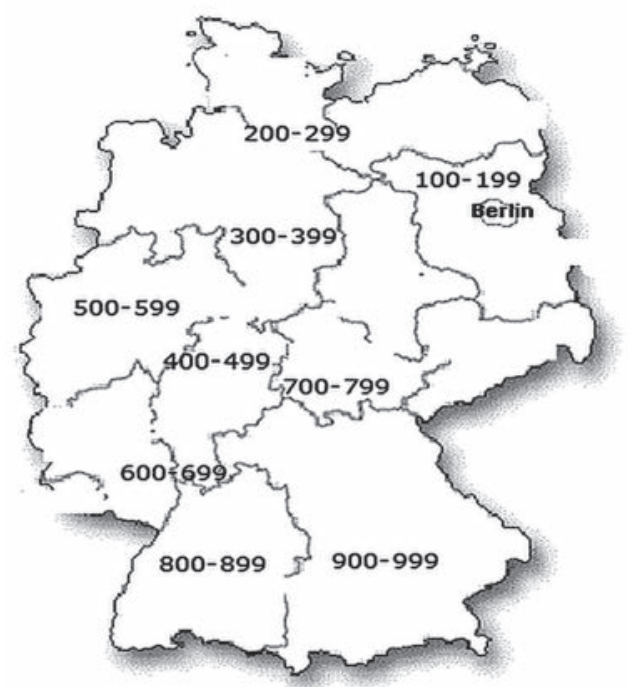

Rysunek 2. Aktualny system numeracji autostrad w Niemczech Źródło: opracowanie - Anna Zmysłowska 
Główną zasada, jaka przyświeca konstruktorom autostrad, jest zapewnienie łatwego i szybkiego przepływu ruchu samochodowego. Większość autostrad charakteryzuje się następującymi cechamí:

- dwa, trzy lub czasami cztery pasy w jedna stronę. Pasy na terenach rolniczych sa zazwyczaj szerokie na 3,75 m, wyjatkiem sa tutaj lewe pasy na nowszych odcinkach trzypasmowych, gdzie szerokość wynosi $3,5 \mathrm{~m}$. Na terenach miejskich wszystkie pasy maja 3,5 m szerokości,

- szerokie na 3,5 lub 4 m pasy zieleni (3 m na terenach miejskich) i przebiegające przez środek bariery zabezpieczajace. Na nowszych fragmentach można spotkać betonowe bariery zamiast pasów zieleni,

- zewnętrzne pasy awaryjne oraz długie pasy wjazdowe i zjazdowe,

- nachylenie poniżej 4\%,

- łagodne i dobrze wyprofilowane zakręty,

- betonowa lub bitumiczna nawierzchnia (o grubości ok. $68 \mathrm{~cm}$ ), odporna na temperaturę poniżej 0 st. Celsjusza,

- ogrodzenia chroniące przyrodę i tunele dla zwierząt.

Co więcej, można spotkać wiele ciekawych udogodnień, takich jak np. częste strefy parkingowe, zautomatyzowany system monitoringu natężenia ruchu i warunków pogodowych, ujednolicony system oznakowania i znaki elektroniczne, które poza standardowymi informacjami ostrzegaja przed korkami, wypadkami, robotami na drodze czy mgła.

Wszystko to nie miałoby racji bytu, gdyby nie odpowiednia konserwacja. Specjalne grupy pracowników okresowo sprawdzają każdy metr kwadratowy sieci przy pomocy specjalistycznych narzędzi do monitorowania stanu dróg. Jeżeli zostanie znaleziona najmniejsza wada, cały odcinek drogi jest wymieniany. To samo dotyczy też znaków, barier itd.

System niemieckich autostrad jest też gęsto zapełniony przez mosty i tunele. Mosty są często wysokie na $500 \mathrm{~m}$ i czasami długie na ponad kilometr. Jeśli chodzi o tunele, to $w$ tym momencie na trasach autostrad jest ich ponad 65. Biegna zarówno przez góry, jak i tereny miejskie. Duży nacisk kładzie się na bezpieczeństwo kierowców w tunelach. Maja je zapewnić: całodobowy monitoring wideo, specjalne informacje podawane $\mathrm{w}$ radiu, "pokoje” $\mathrm{z}$ telefonami awaryjnymi i gaśnicami, awaryjne oświetlenie i wyjazdy oraz specjalne systemy wentylacyjne?.

\footnotetext{
${ }^{6}$ www.gettingaroundgermany.info/autobahn.htm [z dn. 28.10.2011].

7 http://en.wikipedia.org/wiki/German_Autobahnen [z dn. 28.10.2011].
} 


\subsection{Zasady poruszania się, ograniczenia prędkości i punkty obsługi podróżnych}

Żeby poruszanie się w dużym i szybkim ruchu ulicznym na autostradach było jak najbardziej bezpieczne, obowiązują na nich specjalne reguły. Przede wszystkim rowery, motorowery, piesi oraz pojazdy o maksymalnej prędkości mniejszej niż $60 \mathrm{~km} / \mathrm{h}$ nie maja pozwolenia na poruszanie się po autostradzie. Wyprzedzanie z prawej strony jest zabronione. Wolniejsze pojazdy maja obowiązek zjechać na prawą stronę, co umożliwia szybszym pojazdom manewr wyprzedzania. Jest możliwość wyprzedzania z prawej strony jedynie w przypadku dużego ruchu, kiedy wiele pojazdów jedzie blisko siebie z mała prędkością. Takie manewry, jak zatrzymywanie (spowodowane np. brakiem paliwa, co jest możliwe do przewidzenia), parkowanie i zawracanie również są surowo zabronione. Wjazdy i wyjazdy $z$ autostrad sa dopuszczalne tylko w specjalnie przeznaczonych do tego miejscach. Pojazdy włączające się do ruchu na autostradzie muszą ustapić pierwszeństwa pojazdom na niej się znajdującym. Ponadto podczas korków kierowcy jadący z lewej strony są zobligowani do jazdy jak najdalej po lewej stronie. Natomiast Ci, którzy poruszaja się środkowymi i prawymi pasami, muszą trzymać się jak najbliżej prawej strony. Dzięki temu wytwarza się przerwa między pasami dla pojazdów uprzywilejowanych. Jeżeli zdarzy się wypadek, kierowca powinien w miarę możliwości zjechać na pobocze i umieścić trójkąt ostrzegawczy $200 \mathrm{~m}$ za miejscem zdarzenia. Obowiązkiem jest także powiadomienie władz, używając najbliższego telefonu bezpieczeństwa. Nie ma opłat dla kierowców samochodów osobowych chcących skorzystać z autostrad. Opłatami naliczanymi i pobieranymi co kilometr elektronicznie są obciążani kierowcy ciężarowi ${ }^{8}$. W celu znacznego zwiększenia przestrzegania tych przepisów, po autostradach poruszaja się nieoznakowane patrole niemieckiej policji, wyposażone w kamery wideo. Ułatwia to odpowiednie egzekwowanie prawa9.

Jako swego rodzaju dodatek do prawnych regulacji, większość kierowców stosuje następujacce zwyczaje ${ }^{10}$ :

- podczas jazdy na końcu korka włącza się światła awaryjne, żeby ostrzec zbliżające się pojazdy o spowolnieniu,

- zapalenie na chwilę świateł długich lub lewego kierunkowskazu sygnalizuje zamiar wyprzedzania.

\footnotetext{
${ }^{8}$ www.gettingaroundgermany.info/autobahn.htm [z dn. 30.10.2011].

${ }^{9}$ http://en.wikipedia.org/wiki/German_Autobahnen [z dn. 30.10.2011].

${ }^{10}$ www.gettingaroundgermany.info/autobahn.htm [z dn. 30.10.2011].
} 
Pomimo ogólnie znanego przeświadczenia o całkowitej swobodzie odnośnie ograniczeń prędkości na niemieckich autostradach, można znaleźć kilka reguł. Wiele odcinków posiada stałe ograniczenia od 80 do $130 \mathrm{~km} / \mathrm{h}$. Są to w szczególności odcinki z niebezpiecznymi zakrętami, na terenach miejskich, leżące w pobliżu głównych rozjazdów lub te z często spotykanym dużym ruchem samochodowym. Ponadto w strefach, na których wykonywane są prace remontowe czy budowlane, limit sięgną́ może nawet $60 \mathrm{~km} / \mathrm{h}$. Na niektórych segmentach można też dodatkowo spotkać ograniczenia dotyczące jazdy noca czy w niekorzystnych warunkach pogodowych. Mimo to na $2 / 3$ dróg z całej sieci autostrad wciąż nie ma stałych ograniczeń, zaleca się jednak nie przekraczać znacznie prędkości $130 \mathrm{~km} / \mathrm{h}$. W przypadku przekroczenia tego zalecanego progu i udziału w wypadku, kierowca może zostać pociągnięty do odpowiedzialności, nawet jeśli to nie on był sprawca. Oprócz tego ponad $3200 \mathrm{~km}$ autostrad posiada uzależnione od ruchu, pogody i warunków na drodze zmienne ograniczenia prędkości. Ich zastosowanie jest możliwe dzięki umieszczaniu funkcjonalnych znaków elektronicznych ${ }^{11}$. Występują też ograniczenia narzucane niektórym pojazdom, które pokazano w tab. 6 .

Szybkie nowoczesne samochody potrafią z łatwością osiągać prędkości powyżej $230 \mathrm{~km} / \mathrm{h}$. Większość producentów takich pojazdów postępuje zgodnie z niepisaną regułą i elektronicznie ogranicza prędkość maksymalna wytwarzanych przez siebie samochodów do $250 \mathrm{~km} / \mathrm{h}$. Mimo to prędkości przewyższające $300 \mathrm{~km} / \mathrm{h}$ nie są rzadkościa, np. na niezamieszkanych terenach. Przykładami takich odcinków mogą być A 8 między Stuttgartem i Monachium czy A 81 między Stuttgartem i Singen. Około $150 \mathrm{~km}$ tego ostatniego odcinka nie ma ograniczenia prędkości ${ }^{12}$.

Tabela 6. Ograniczenia prędkości narzucane niektórym pojazdom

\begin{tabular}{|c|l|}
\hline $60 \mathrm{~km} / \mathrm{h}$ & $\begin{array}{l}\text { Autobusy przewożace stojących pasażerów, } \\
\text { motocykle z przyczepami. }\end{array}$ \\
\hline $80 \mathrm{~km} / \mathrm{h}$ & $\begin{array}{l}\text { Pojazdy z maksymalna dopuszczalną waga przekraczajacą 3,5 t } \\
\text { (oprócz samochodów osobowych), } \\
\text { samochody osobowe i ciężarowe z przyczepami, autobusy. }\end{array}$ \\
\hline $100 \mathrm{~km} / \mathrm{h}$ & $\begin{array}{l}\text { Samochody osobowe z przyczepami certyfikowanymi na } 100 \mathrm{~km} / \mathrm{h}, \\
\text { autobusy certyfikowane na } 100 \mathrm{~km} / \mathrm{h} .\end{array}$ \\
\hline
\end{tabular}

Źródło: opracowanie własne na podstawie http://en.wikipedia.org/wiki/German_ Autobahnen [z dn. 30.10.2011].

\footnotetext{
11 Tamże.

12 http://en.wikipedia.org/wiki/German_Autobahnen [z dn. 30.10.2011].
} 
Co zaskakujące, przy większości autostrad bez ograniczeń prędkości wskaźniki wypadków i śmierci na drogach są bardzo niewielkie. Po autostradach porusza się około $1 / 3$ całego niemieckiego ruchu samochodowego, jednak wypadki na nich to jedynie 6\% takich zdarzeń w skali całego kraju i mniej niż $12 \%$ wszystkich wypadków śmiertelnych (dane na 2004 r.). Co więcej, roczny wskaźnik zgonów na skutek wypadków (3,2 na bilion przejechanych kilometrów w 2004 r.) jest niższy od innych krajów z dobrze rozwiniętymi systemami autostrad, jak np. USA (5,0 w 2003 r. $)^{13}$.

Położenie Niemiec w Europie Centralnej powoduje spory ruch na tamtejszych autostradach. W 2004 r. kierowcy przejechali 218,9 bln km autostradami, co dało średnią prawie 50000 pojazdów dziennie na dowolnie wybranym odcinku. Korki uliczne są zatem częstym zjawiskiem, występującym zwłaszcza w piątki, niedziele, dni wolne od pracy oraz po wypadkach, podczas złych warunków pogodowych czy przebudowy. Żeby w jak największym stopniu temu zapobiegać, Niemcy zostały podzielone na kilka stref, a przy drogach ustawiono znaki informujące o częstotliwościach nadawania radia, które na bieżąco informuje o stanie zatłoczenia na drodze $w$ danym regionie. $W$ niemieckich samochodach działa to $w$ ten sposób, że nawet jeśli kierowca słucha kasety lub płyty $C D$, radio nadaje specjalny sygnał oznaczający początek raportu o stanie ruchu ulicznego i wyłącza inne odtwarzacze dźwięku. Wiele odcinków autostrad wyposażonych jest w specjalne systemy monitorujące ruch i w znaki elektroniczne. Maja one na celu ostrzegać kierowców przed zbliżającym się korkiem i wymusić zmniejszenie prędkości. Na odcinkach, gdzie elektronicznych znaków nie ma, policja stara się ostrzegać przed niespodziewanymi korkami za pomocą przenośnych znaków lub znaków umieszczanych na samochodach zaparkowanych wzdłuż pobocza. Informacje o aktualnym stanie ruchu ulicznego są również dostępne na stronach internetowych stacji radiowych, kanałów telewizyjnych, auto-klubów, agencji rządowych czy - w coraz większym stopniu - poprzez systemy telematyczne. Tymczasowym środkiem pomocy podczas zatłoczenia na niektórych odcinkach jest też możliwość korzystania z pasu bezpieczeństwa (takie odcinki są oznaczone specjalnymi znakami ${ }^{14}$.

Niemieckie autostrady posiadaja rozległy system punktów obsługi podróżnych (niem. Rasthof lub Raststätte), rozmieszczonych zazwyczaj co 40-60 km. Znaleźć na nich można stacje benzynowe, restauracje,

\footnotetext{
${ }^{13}$ www.gettingaroundgermany.info/autobahn.htm [z dn. 30.10.2011].

14 Tamże.
} 
bary szybkiej obsługi, sklepy z podstawowymi artykułami, telefony i toalety. Ponadto większość posiada hotele, ośrodki rozrywkowe (boiska, place zabaw), sale konferencyjne i kaplice. Takich działających i pracujących punktów jest ponad 700. Są one otwarte przez $24 \mathrm{~h}$ na dobę. W każdym (oraz w Internecie) można otrzymać ulotkę z mapa pokazująca cała sieć punktów i zaplecze dostępne na każdym z nich ${ }^{15}$.

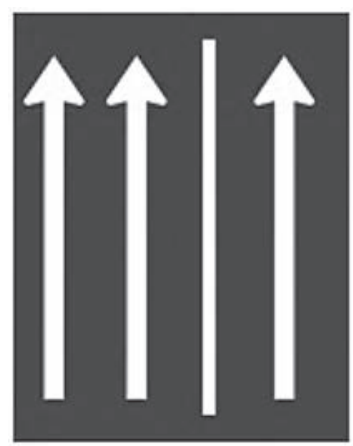

Rysunek 3. Znak pozwalający na jazdę po pasie bezpieczeństwa podczas dużego ruchu ulicznego

Źródło: opracowanie - Anna Palczewska

Znaki informujące o zbliżającym się punkcie obsługi zawierają jego nazwę, odległość od niego i jeden obrazek (lub więcej) ilustrujący oferowane usługi.

W ciagu ostatnich kilkunastu lat wzrosła liczba stref usługowych w niewielkiej odległości od zjazdów z autostrad (głównie stacje benzynowe i bary szybkiej obsługi). Szczególną popularność zdobywaja zajazdy dla pojazdów ciężarowych (niem. Autohof), oferujące podobne do punktów obsługi zaplecze, lecz o znacznie niższych cenach ${ }^{16}$.

\subsection{Oznakowanie i bezpieczeństwo na autostradach w Niemczech}

Rozległa sieć autostrad wymaga odpowiedniego i czytelnego oznakowania. Bez watpienia takie właśnie znaki można spotkać w Niemczech. Wszystkie wskaźniki kierunkowe na autostradach, a także znaki wskazujące kierunek dojazdu na nie, są koloru białego na niebieskim tle.

\footnotetext{
15 Tamże.

16 Tamże.
} 
Znaki przed rozjazdami są jednolite, jeśli chodzi o formę i umiejscowienie. Coraz większą popularnością cieszą się znaki wiszące. Numery dróg umieszczone są zazwyczaj na dole znaku, a poszczególne miasta na trasie wypisywane są od najdalszego (na górze) do najbliższego (na dole znaku). Jak wspomniano wcześniej, autostrady numerowane są jedna, dwiema lub trzema cyframi i przedrostkiem "A". Przedrostek ten nie jest jednak na znakach pokazany ${ }^{17}$. Główne znaki spotykane na tamtejszych autostradach przedstawiono $\mathrm{w}$ tab. 7.

Tabela 7. Najważniejsze znaki z niemieckich autostrad

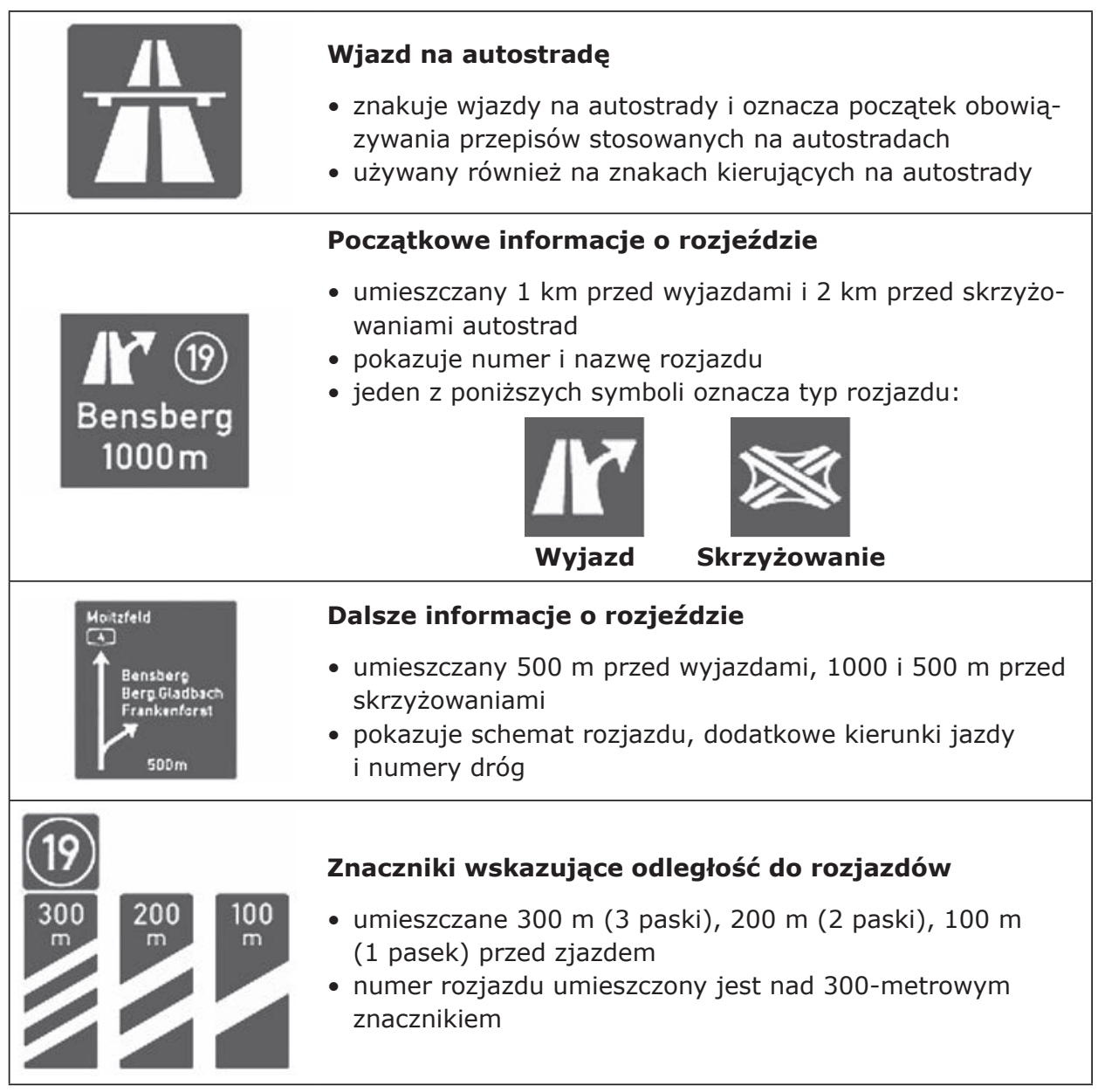

17 Tamże. 
Tab. 7 (cd.)

\begin{tabular}{|c|c|}
\hline $\begin{array}{l}\text { Bensberg } \\
\text { Berg.Gladbach } \\
\text { Frankenforst }\end{array}$ & $\begin{array}{l}\text { Znak zjazdowy } \\
\text { - umieszczany w punkcie zjazdu } \\
\text { - jako znak wiszacy może być powtórzony kilka razy nad } \\
\text { pasem zjazdowym }\end{array}$ \\
\hline & $\begin{array}{l}\text { Znak zjazdowy } \\
\text { • wskazuje zjazd z autostrady }\end{array}$ \\
\hline & $\begin{array}{l}\text { Objazd tymczasowy } \\
\text { - znakuje drogi zastępcze w przypadkach, kiedy autostrada } \\
\text { musi zostać zamknięta } \\
\text { - numery parzyste biegna w jedna stronę takiej drogi, } \\
\text { a numery nieparzyste - w przeciwną }\end{array}$ \\
\hline & $\begin{array}{l}\text { Schemat objazdu } \\
\text { - używany do kierowania ruchu na następny objazd w przy- } \\
\text { padku, gdy nie można wrócić na autostradę na najbliższym } \\
\text { wjeździe }\end{array}$ \\
\hline & $\begin{array}{l}\text { Droga alternatywna } \\
\text { - wskazuje rekomendowaną drogę alternatywna dla spe- } \\
\text { cyficznych pojazdów lub kierunków, w celu zapobiegania } \\
\text { kongestii } \\
\text { - typ pojazdu lub kierunku jest pokazany na znaku połączo- } \\
\text { nym z pokazanym tutaj }\end{array}$ \\
\hline $\begin{array}{lr}\text { Köln } & 106 \mathrm{~km} \\
\text { Dortmund } & 24 \mathrm{~km} \\
44 \text { Kassel } & 161 \mathrm{~km}\end{array}$ & $\begin{array}{l}\text { Znak z odległościami } \\
\text { - umieszczany po każdym wjeździe na autostradę } \\
\text { - pokazuje odległości do głównych miast wzdłuż drogi } \\
\text { - odległości do innych, pobliskich dużych miast, dostępnych } \\
\text { dzięki przecinajacym autostradom, pokazane są na dole } \\
\text { z odpowiednim numerem }\end{array}$ \\
\hline & $\begin{array}{l}\text { Koniec autostrady } \\
\text { - umieszczany na drogach zjazdowych; oznacza koniec obo- } \\
\text { wiązywania przepisów dotyczących ruchu po autostradzie }\end{array}$ \\
\hline
\end{tabular}

Źródło: niemiecki kodeks drogowy, za: http://www.kodeksdrogowy.com.pl/pobierz/ zagraniczne/kod_niemcy\%28Strassenverkehrs-Ordnung\%29.pdf [z dn. 15.10.2012]. 
Znaki poziome sa dosyć oczywiste i bardzo podobne do tych spotykanych chociażby u nas w kraju:

- linia ciągła - wyznacza lewą krawędź drogi, a z prawej strony pobocze lub prawą krawędź drogi; czasami malowana również pomiędzy pasami ruchu w celu zakazu zmiany pasa,

- długie cienkie linie przerywane - rozdzielaja pasy ruchu,

- krótkie grube linie przerywane - rozdzielaja pasy zwalniające (zjazdy) lub pasy rozbiegowe (wjazdy) od głównych pasów ruchu,

- oznaczenia ukośne - wskazuja powierzchnię, na która wjazd i zatrzymywanie się są zabronione,

- żółte oznaczenia - używane np. w miejscach budowy, zastępują wszystkie standardowe białe oznaczenia ${ }^{18}$.

Oprócz znanych nam znaków poziomych i pionowych, przez ostatnie lata niemieccy inżynierowie rozwinęli zaawansowane systemy kontroli ruchu do zarządzania nim na licznych autostradach i nowoczesnych drogach. Te zautomatyzowane systemy składaja się z licznych kamer nadzorujących, przyrządów kontrolujących prędkość i znaków elektronicznych (wyposażonych w specjalne urządzenia do wykrywania i automatycznego ostrzegania przed mgła, deszczem czy lodem). Cel, jaki przyświecał wprowadzeniu tego typu systemów, to stopniowe zmniejszanie prędkości pojazdów zbliżających się do miejsc zakorkowanych, w przebudowie lub z trudnymi warunkami pogodowymi. Jak pokazały badania, dzięki nim liczba wypadków spadła o 30\% w ciągu 3 lat po ich wprowadzeniu. Niemiecki rząd, widząc $\mathrm{w}$ tym rozwiązaniu duży potencjał, cały czas chce kontynuować jego rozwój. Przykładowo, w 2007 r. przeznaczono na ten cel ok. 200 mln euro ${ }^{19}$.

Tylko kilka znaków elektronicznych pokazywanych jest za pomoca krótkich, zrozumiałych wiadomości tekstowych. Większość to podobizna normalnych znaków stawianych przy drodze. Pozwala to stosować standardowe, znane obrazki, ostrzegające przed warunkami występujacymi dalej na trasie lub wprowadzające zmienne regulacje. Zwyczajowo używa się ich do tymczasowego ograniczenia prędkości, w odpowiedzi na warunki drogowe i pogodowe. Czasami takie ograniczenia są ustalane oddzielnie dla poszczególnych pasów ruchu. Większość kierowców jednogłośnie chwali fakt, że limity te sa w przeważajacej części adekwatne do warunków jazdy. Warto podkreślić, że informacje i regulacje pokazywane na znakach elektronicznych sa łatwe do wyegzekwowania,

\footnotetext{
18 Tamże.

19 Tamże.
} 
ponieważ w większości stref zamontowane są fotoradary (zintegrowane z całym systemem), "świadome" aktualnego ograniczenia ${ }^{20}$. Znaczenie niektórych znaków przedstawiono w tab. 8.

Tabela 8. Znaczenie niektórych znaków elektronicznych

Zakaz ruchu pojazdów o masie wyższej niż 3,5 t

20 Tamże. 
Tab. 8 (cd.)

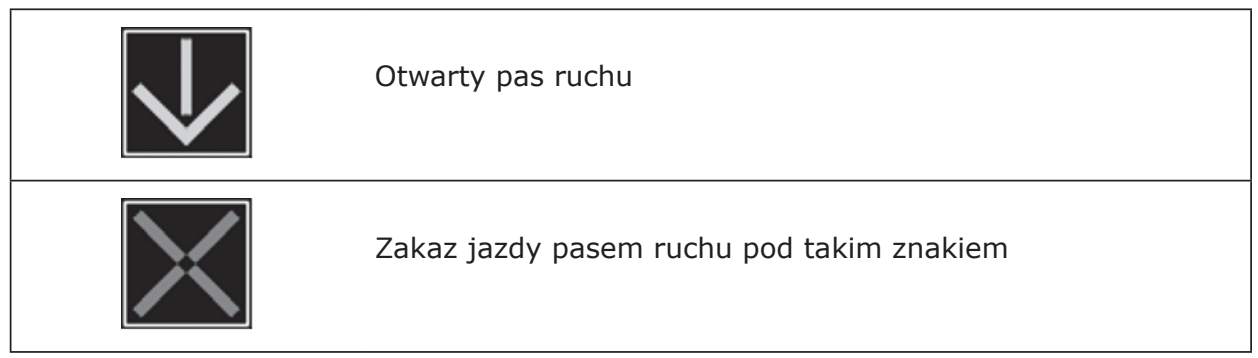

Źródło: jak do tab. 7.

W przypadku kolizji, awarii czy innej nagłej, nieprzewidzianej sytuacji na autostradzie, kierowca i pasażerowie znajduja się zawsze nie więcej niż kilometr od pomocy. Telefony bezpieczeństwa (niem. Notrufsäule) umieszczone sa wzdłuż dróg z dwukilometrowa przerwą. Kierunek do najbliższego takiego telefonu jest pokazany małymi strzałkami, znajdującymi się na górze ustawionych na poboczu słupków. W dłuższych tunelach telefony znajduja się w pokojach bezpieczeństwa co 100-200 m. System telefonów bezpieczeństwa został sprywatyzowany kilka lat temu. Wszystkie połączenia kierowane są do centrum w Hamburgu. Dyspozytorzy natychmiast staraja się łączyć potrzebujących np. z najbliższym posterunkiem policji czy pomoca drogowa. W przypadku awarii, telefoniści proszą o podanie najważniejszych informacji w celu wysłania odpowiedniej pomocy. Zależnie od pory dnia i warunków na drodze, odpowiedź na wezwanie może trwać od kilku minut do ponad godziny. Służby, które odpowiadaja na wezwania dotyczące wypadków, to policja, straż pożarna, pogotowie ratunkowe lub nawet pogotowie medyczne $w$ helikopterze. Obecnie spotyka się dwa rodzaje telefonów bezpieczeństwa. W wersji starszej, z zasłona i uchwytem, który trzeba podnieść i poczekać na zgłoszenie się dyspozytora, oraz w wersji nowszej, gdzie zamiast zasłony mamy do czynienia z powierzchnią głośnikowo-mikrofonową i dwoma przyciskami służącymi do łączenia z odpowiednimi operatorami (żółtym do zgłoszenia awarii i czerwonym do zgłoszenia wypadku). W większości przypadków lokalizacja telefonu przesyłana jest automatycznie po nawiązaniu połączenia, a jeśli nie - trzeba ja podać dyspozytorowi, odwołując się do naklejki umieszczonej na telefonie ${ }^{21}$.

Mimo wielu zalet i dobrych rozwiązań, autostrady w Niemczech, tak jak w każdym innym kraju, zużywają się, co skutkuje często spotykany-

${ }^{21}$ Tamże. 
mi rozległymi strefami w przebudowie. W przypadku dużych projektów standardowy sposób postępowania to zwężanie i umieszczanie pasów w obu kierunkach po jednej stronie autostrady. Dzięki temu zabiegowi na całości drugiej strony można prowadzić prace budowlane i usprawniajace. O takich sytuacjach ostrzegaja specjalne znaki, a ograniczenia prędkości sa znacznie zmniejszone. Natomiast dla okoliczności, kiedy wymagane jest zamknięcie całego odcinka autostrady, przygotowane sa specjalne objazdy, oznaczone zaprezentowanymi wcześniej znakami22.

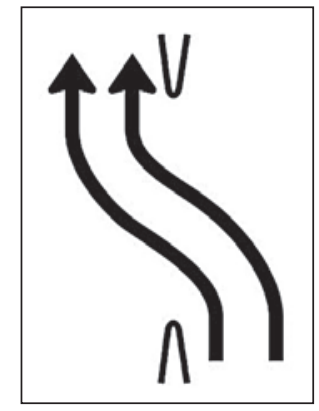

Rysunek 4. Znak informujący o nakazie zmiany pasa ruchu np. w sytuacji przebudowy

Źródło: opracowanie - Anna Palczewska

\section{Podsumowanie}

W wyniku analiz przeprowadzonych w niniejszym rozdziale można sformułować następujace wnioski:

- Niemieckie autostrady sa podobne do nowszych odcinków powstających w Polsce.

- Główne zadanie autostrad w Niemczech to zapewnienie łatwego do nich dostępu i szybkiego ruchu samochodowego.

- Sieć autostrad w Niemczech posiada wiele udogodnień optymalizujących ruch i minimalizujących ryzyko wypadku, takich jak: często występujace miejsca obsługi podróżnych, zautomatyzowany system monitoringu natężenia ruchu, znaki elektroniczne, gęsta sieć mostów i tuneli, telefony bezpieczeństwa.

- System infrastruktury drogowej w Niemczech jest jednym z lepszych i efektywniejszych na świecie. 



\section{System autostrad jako rozwiązanie usprawniające transport w miastach na podstawie aglomeracji berlińskiej}

Michał Głowacki*

\subsection{Historia rozwoju sieci autostrad w Niemczech oraz w aglomeracji berlińskiej}

W Niemczech plany budowy sieci autostrad obejmujacej cały kraj pojawiły się już w czasach Republiki Weimarskiej. Sieć ta, znana do roku 1945 i upadku III Rzeszy pod nazwą Reichsautobahn, miała połączyć najważniejsze niemieckie miasta. Szczególnie istotne miejsce w tych planach zajmował Berlin - stolica Niemiec, najważniejsze strategicznie, a zarazem najbardziej zaludnione miasto w całym kraju. Zaplanowano wokół niego zewnętrzną autostradową obwodnicę, oznaczoną jako Reichsautobahn (RAB) 7.

Pierwszym odcinkiem autostrady, który powstał w aglomeracji berlińskiej było Automobil-Verkehrs- und Übungs-Straße (niem. ulica ruchu automobilowego i ćwiczebna), tzw. AVUS. Jest to jeden z najstarszych odcinków autostrady w Niemczech i całej Europie. Został zaproponowany i zaprojektowany przez Automobilclub von Deutschland (niemiecki klub samochodowy) w 1907 r. jako tor wyścigowy oraz jako miejsce do przeprowadzania testów dla przemysłu samochodowego. Z powodów finansowych prace budowlane rozpoczęły się dopiero po 6 latach, w roku 1913. Podczas I wojny światowej do pracy przy budowie toru zaciągnięto jeńców wojennych z całej Europy. Został on oddany do użytku w roku 1921, do czego bardzo przyczynił się przedsiębiorca H. Stinnes, pomagajac $w$ finansowaniu projektu. Konstrukcja toru to dwie długie proste $\mathrm{w}$ formie dwupasmowej jezdni, z dwiema pętlami do nawrotu na obydwóch końcach. Długość toru wynosiła 19,5km, a każda prosta liczyła ok. połowy tej długości. W 1926 r. na AVUS odbyło się pierwsze

* Mgr Michał Głowacki - Katedra Logistyki, Wydział Zarządzania Uniwersytetu Łódzkiego, ul. Matejki 22/26, 90-237 Łódź. 
w historii Grand Prix Niemiec, a w roku 1959 zagościła na tym torze jedyny raz Formuła 1, kiedy zorganizowano tam Grand Prix Niemiec, tym razem $w$ ramach mistrzostw świata Formuły 1 . Wyścigi samochodowe urządzano do maja 1998 r. $^{1}$ Obecnie AVUS to niezwykle istotna część systemu drogowego w Berlinie i północny odcinek autostrady A 115 - stanowi prawie $10 \mathrm{~km}$ tej drogi².

Pomimo sukcesu, jakim niewątpliwie było wybudowanie AVUS, autostrady w Niemczech powstawały bardzo powoli. Ze względu na problemy ekonomiczne i brak wsparcia politycznego proces budowy większości odcinków nie wychodził poza fazę planowania. Sytuacja zmieniła się po przejęciu władzy przez NSDAP. W tamtym czasie w Niemczech panowało ogromne bezrobocie - bez pracy pozostawało nawet $6 \mathrm{mln}$ ludzi. Naziści poszukiwali projektu robót publicznych, które umożliwiłyby zmniejszenie bezrobocia, a dodatkowo posłużyły do celów propagandowych i wzmocnienia jedności narodowej. Adolf Hitler zaadaptował projekt sieci szybkich publicznych dróg, pojawiający się już w Republice Weimarskiej, jako własny pod nazwą Reichsautobahn, który rzekomo obmyślił podczas swojego pobytu w więzieniu. W ten sposób powstał mit "dróg führera" - jego osobistego daru dla narodu niemieckiego. Z perspektywy czasu można stwierdzić, że projekt ten posłużył również do zapewnienia mobilności siłom wojskowym III Rzeszy. Zemściło się to jednak na nazistach, kiedy ich autostrady zostały wykorzystane przez siły aliantów po ich wkroczeniu na terytorium Niemiec ${ }^{3}$.

W czerwcu 1933 r. Hitler zatwierdził 7-letni plan budowy 7000 km autostrad, $1000 \mathrm{~km}$ rocznie. Do pracy miano zatrudnić nawet 600 tys. osób, jednak z powodu bardzo ciężkich warunków pracy oraz niskich pensji przy budowie autostrad pracowało maksymalnie 120 tys. osób. Jeszcze we wrześniu tego samego roku Hitler uroczyście zainaugurował budowę 28-kilometrowego odcinka Frankfurt-Darmstadt ${ }^{4}$. Był to pierwszy odcinek oddany do użytku przez nazistowskie władze, co miało miejsce w 1935 r. Pod koniec tego roku w Niemczech istniało $108 \mathrm{~km}$ autostrad. Rok później suma ich długości wynosiła już 1087 km. Pierwsze $1000 \mathrm{~km}$ autostrad powstało, co prawda, w 3 lata, ale i tak tempo prac było - jak na tamte czasy - niesamowite. Do wybuchu II wojny

\footnotetext{
${ }^{1}$ www.etracksonline.co.uk/europe/Germany/avus21-36.html [z dn. 29.10.2011].

2 www.autobahnatlas-online.de/A115.htm [z dn. 29.10.2011].

${ }^{3} \mathrm{http}$ ://archiwum. polityka.pl/art/droga-do-autostrad,355706.html [zdn. 29.10.2011].

${ }^{4}$ Tamże.
} 
światowej położono ich prawie $3300 \mathrm{~km}$. Wysiłek wojenny ponoszony przez III Rzeszę zatrzymał budowy dopiero w 1943 r. Do tego czasu wybudowano łącznie $3893 \mathrm{~km}$ autostrad ${ }^{5}$. Wojna pozostawiła niemiecką sieć autostrad $\mathrm{w}$ fatalnym stanie - wiele odcinków dotknęły zniszczenia wojenne, m.in. w wyniku bombardowań. Tysiące kilometrów planowanej sieci Reichsautobahn pozostały nieukończone.

W czasie nazistowskiej propagandy sukcesu i mitu "dróg führera" częściowo powstał najważniejszy element sieci drogowej aglomeracji berlińskiej - Berliner Ring. Pierwsze odcinki zostały oddane do użytku już w 1936 r. Były to: 6,7 km autostrady pomiędzy węzłami "Werder" i "Groß Kreutz" na południowy wschód od Berlina oraz 1,6-kilometrowy odcinek "Weißensee"-,Schwanebeck" w północno-wschodniej części Ringu. Rok później była już całkowicie gotowa wschodnia część obwodnicy, po tym jak wybudowano $40,3 \mathrm{~km}$ autostrady pomiędzy węzłami "Schwanebeck" i "Spreeau". W południowej części oddano w tym samym roku 16,7-kilometrowy odcinek "Potsdam-Süd"-,Werder". W 1938 ukończono budowę 50,5 km obwodnicy w części "Spreeau"-",Potsdam-Süd". 13,2-kilometrowy etap "Groß Kreutz"-,"Potsdam-Nord" oddany w 1939 r., w południowo-zachodniej części obwodnicy, był ostatnim odcinkiem Berliner Ringu oddanym do użytku w czasach III Rzeszy. Łącznie wybudowano $129 \mathrm{~km}$ autostrady ${ }^{6}$. Zaplanowana była również północno-wschodnia część Berliner Ring, jednak plany te nie zostały zrealizowane z powodu trwającej wtedy II wojny światowej.

W aglomeracji berlińskiej jeszcze przed zakończeniem II wojny światowej wybudowana została także autostrada A 115. Pierwszy jej odcinek ukończono w 1921 r., a był to wspomniany wcześniej AVUS. Później został on połączony z Berliner Ringiem za pomoca dwóch odcinków oddanych do użytku w 1940 i 1941 r. i liczących odpowiednio 16,8 oraz 2,7 km?.

Mapę autostrad zaplanowanych, ale nie zrealizowanych oraz tych wybudowanych w III Rzeszy do roku 1941 w okolicach aglomeracji berlińskiej przedstawia rys. 5. Linia ciągła zostały zaznaczone autostrady, które zostały oddane do użytku. Linią przerywaną zaznaczono planowane autostrady, których budowę jednak wstrzymano.

${ }^{5}$ D. Kaszubowski, Infrastruktura transportu $w$ procesie zjednoczenia Niemiec po 1990 r., cz. 1, "Infrastruktura Transportu” 2009, nr 2, s. 32, za: http://www. infrastruktura.elamed.pl/strona-numer-2-2009-25269.html [z dn. 29.10.2011].

${ }^{6}$ www.autobahnonline.de/ddrautobahnen.html [z dn. 29.10.2011].

7 www.autobahnonline.de/geschichte.html [z dn. 29.10.2011]. 


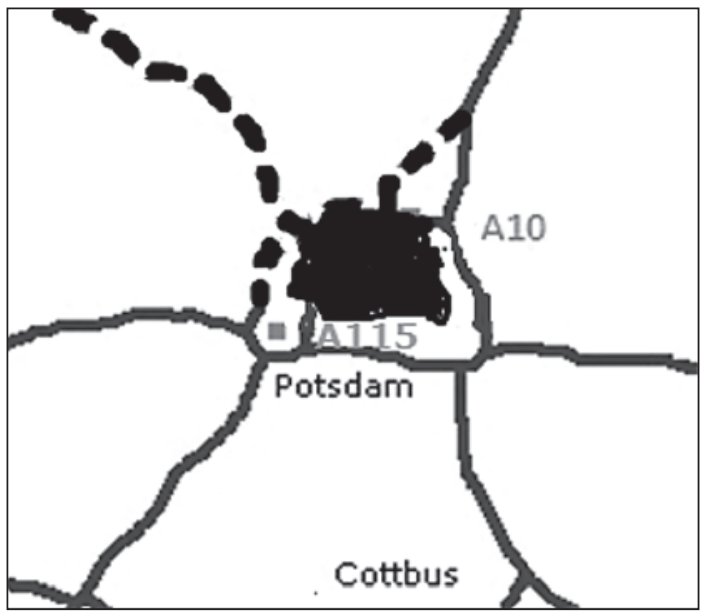

Rysunek 5. Mapa autostrad oraz planowanych autostrad na obszarze aglomeracji berlińskiej w $1941 \mathrm{r}$.

Źródło: opracowanie - Anna Zmysłowska

Po II wojnie światowej Niemcy zostały podzielone na 2 państwa: Niemiecką Republikę Demokratyczną (NRD) i Republikę Federalną Niemiec (RFN). Region Brandenburgii i Berlina prawie w całości znalazł się w komunistycznej NRD. Wyjatek stanowił Berlin Zachodni, który był enklawą na terytorium Niemiec Wschodnich zarządzana przez aliantów.

Po podziale Niemiec $2106 \mathrm{~km}$ autostrad znalazło się na terytorium RFN, co stanowiło większość $(54,1 \%)$ liczącej przed zakończeniem II wojny światowej $3893 \mathrm{~km}$ sieci Reichsautobahn. W granicach NRD pozostało $1366 \mathrm{~km}$ słynnych "dróg führera” (35,1\%), 365 km (9,4\%) znalazło się na Ziemiach Odzyskanych powojennej Polski, a pozostała część $(1,4 \%)$ w Związku Socjalistycznych Republik Radzieckich w rejonie Królewca oraz w Austrii w rejonie Salzburga. Na terytorium NRD autostrady były zaniedbywane, w czasach zimnej wojny dokonywano tylko minimalnych konserwacji. Zupełnie inna sytuacja miała miejsce w RFN, gdzie już w latach 50. XX wieku wznowiono program budowy systemu autostrad. Te dwa podejścia poskutkowały poważnymi różnicami infrastruktury drogowej w dniu zjednoczenia Niemiec. W latach 1950-1990 w NRD powstało ok. $500 \mathrm{~km}$ nowych autostrad oraz przebudowano ok. $400 \mathrm{~km}$ już istniejacych. W tym samym czasie na terytorium RFN wybudowano ok. $6700 \mathrm{~km}$ nowych autostrad oraz dokonano unowocześnień starszych odcinków ${ }^{8}$.

\footnotetext{
${ }^{8}$ D. Kaszubowski, Infrastruktura transportu..., s. 32.
} 
Pierwszy odcinek autostrad w powojennym Berlinie został wybudowany w 1958 r. i liczył 1,3 km. Miało to miejsce w Berlinie Zachodnim, który rozpoczał projekt budowy śródmiejskiej autostrady - obecnie jest to A 100 (wraz z wybudowanymi w latach 70. i 80. XX wieku krótkimi odnogami A 102, A 103, A 104). Projekt ten możliwy był do realizacji głównie dzięki hojnym subwencjom płynącym z RFN. Autostrada A 100 jest cały czas rozbudowywana. Ostatni odcinek został oddany do użytku w 2004 r., jednak planowane sa kolejne. Na terytorium Berlina Zachodniego znajdowała się również wybudowana w III Rzeszy autostrada A 115, która stanowiła jedną z dróg tranzytowych łączących enklawę z RFN. Ciekawostka jest, że na 3-kilometrowym odcinku droga ta trzykrotnie przekraczała „żelazną kurtynę”, co było niezwykle kłopotliwe dla władz NRD. Włodarze Niemiec wschodnich postanowili wybudować objazd po swojej stronie, co zrealizowano w 1969 r. Rolę tranzytu z Berlina Zachodniego pełniła również ukończona całkowicie w 1987 r. autostrada A 111. W enklawie wybudowano również jej śródmiejską odnogę - A 105 (zakończenie prac w 1981 r.).

W NRD pierwsze nowe autostrady w powojennej aglomeracji berlińskiej otworzono dopiero w latach 60 . XX wieku. W Niemczech wschodnich udało się wybudować odcinki autostrad: A 111 (odcinek gotowy w 1982 r.), A 113 (1963 r.) oraz A 114 (1973-1982). Jednakże największym projektem było dokończenie budowy Berliner Ringu. W roku 1972 oddano do użytku nowy, 18-kilometrowy odcinek w północnej części obwodnicy. Prace budowlane nad kolejnymi częściami autostrady były kończone w latach 1973-1974, a Berliner Ring został domknięty w 1979 r., kiedy wybudowano ostatni, 27,6-kilometrowy odcinek ${ }^{10}$.

Po zjednoczeniu Niemiec w 1990 r. priorytetem w sferze infrastruktury transportu drogowego stał się proces wyrównania różnic pomiędzy systemami drogowymi NRD i RFN. Problem ten ujęto w Programie Transportowego Zjednoczenia Niemiec, zaprezentowanym w 1991 r. i obejmującym 17 projektów infrastrukturalnych, w tym 7 drogowych. Na koniec 2009 r. program został już prawie ukończony, a w jego ramach wybudowano i wyremontowano ok. $2100 \mathrm{~km}$ autostrad ${ }^{11}$.

Po 1990 r. rozpoczęto proces powtórnego planowania autostrad w Berlinie. W wyniku tych działań z części dotychczasowej A 113 wydzielono autostradę A 117 oraz wybudowano nowe odcinki A 113, tak aby była zgodna z nowym planem. W 2006 r. śródmiejskie autostrady

\footnotetext{
${ }^{9}$ www.autobahnonline.de/geschichte.htm [z dn. 29.10.2011].

${ }^{10}$ www.autobahnonline.de/ddrautobahnen.html [z dn. 29.10.2011].

${ }^{11}$ www.gettingaroundgermany.info/autobahn.shtml [z dn. 29.10.2011].
} 
A 102 i A 104 zostały dołączone do autostrady A 100; podobny los spotkał A 105, która stała się częścią A 111. Ostatni odcinek sieci autostrad w aglomeracji berlińskiej został oddany do użytku w 2008 r. (odcinek A 113), jednakże sieć ta jest nadal rozwijana ${ }^{12}$.

\subsection{System autostrad w Niemczech}

Niemiecki system autostrad liczy obecnie ok. 12550 km³, co oznacza, że jest najbardziej rozwinięta siecią pod względem wielkości w Europie, a trzecią na świecie. Większą łączną długość mają tylko autostrady w Stanach Zjednoczonych i Chińskiej Republice Ludowej ${ }^{14}$. Sieć autostrad obejmuje całe terytorium Niemiec i zapewnia połączenia pomiędzy wszystkimi ważniejszymi miastami.

Obecna numeracja autostrad jest używana od 1974 r. Oznaczenie wszystkich autostrad rozpoczyna się od wielkiej litery " $A$ ", co oznacza Autobahn (niem. autostrada), dalej jest odstęp, a po nim numer. System numeracji jest następujący ${ }^{15}$ :

- główne autostrady, przechodzące przez większą część kraju, są oznaczone jednocyfrowa liczba, tj. od A 1 do A 9; np. autostrada A 7, która zaczyna się na granicy z Danią na północy Niemiec, przebiega przez cały kraj i kończy się w południowej części na granicy z Austria, - krótsze autostrady, posiadające znaczenie regionalne, przykładowo - łączące dwa duże miasta lub regiony na terenie Niemiec, oznaczone sa liczbami dwucyfrowymi, tj. od A 10 do A 99. Pierwsza cyfra oznacza dany region, np. autostrady od A 10 do A 19 są położone we wschodniej części Niemiec (Berlin, Saksonia-Anhalt, część Saksonii i Brandenburgii),

- krótkie odcinki autostrad o znaczeniu lokalnym oznaczone sa trzycyfrowa liczba, tj. od A 100 do A 999. Pierwsza cyfra oznacza dany region, taki sam jak przy oznaczeniu autostrad o znaczeniu regionalnym - np. autostrada A 100 jest obwodnica śródmieścia Berlina.

Wielu kierowców, którzy po raz pierwszy korzystaja z niemieckich autostrad jest zawiedzionych, że nie spełniaja one ich oczekiwań. Spodziewaja się dwudziestopasmowych dróg, zaś autostrady w Niemczech

${ }^{12}$ www.autobahnonline.de/geschichte.htm [z dn. 29.10.2011].

${ }^{13}$ www.bmvbs.de/en/Transport/Roads-,1900.963681/Roads.htm [zdn. 16.02.2010].

${ }^{14}$ www.trails.com/facts_11038_information-german-autobahn-highway.html [z dn. 29.10.2011].

${ }^{15}$ www.autobahn-online.de/auswahl.html [z dn. 29.10.2011]. 
posiadaja przeważnie dwa lub trzy, okazjonalnie cztery pasy ruchu w danym kierunku jazdy. Pasy na autostradach mają wyznaczoną szerokość - 3,75 m, oprócz lewych pasów nowszych trójpasmowych odcinków oraz wszystkich pasów na autostradach przebiegających przez tereny zurbanizowane, gdzie ten wymiar wynosi 3,5 m. Oddzielające kierunki jazdy pasy zieleni na odcinkach pozamiejskich są szerokie na 3,5 lub $4 \mathrm{~m}$, zaś na autostradach znajdujących się w miastach - na $3 \mathrm{~m}$. Na niektórych nowszych odcinkach zostały umieszczone bariery zamiast pasów zieleni. Dodatkowo na niemieckich autostradach znajduja się pasy awaryjne, zjazdowe oraz rozbiegowe, służące do włączania się do ruchu przy wjeździe ${ }^{16}$.

Przy projektowaniu autostrad istotne jest również nachylenie drogi, które w Niemczech nie może przekroczyć 4\%. Kolejnym ważnym elementem są łuki - muszą być one łagodne i posiadać odpowiedni promień. Przy budowie używane są mrozoodporne betonowe lub bitumiczne nawierzchnie, a ich grubość musi wynosić ok. $75 \mathrm{~cm}$. Projektanci nie moga zapomnieć także o obszarze ochrony środowiska, gdzie zastosowane znajduja takie rozwiązania, jak m.in.: tunele i mosty dla zwierząt oraz ogrodzenia dróg. Dla zapewnienia użytkownikom autostrad bezpieczeństwa i wygody wykorzystuje się również ${ }^{17}$ :

- parkingi, często wyposażone w toalety,

- miejsca obsługi podróżnych, na terenie których w wielu przypadkach znajduja się stacje benzynowe, restauracje i hotele,

- telefony alarmowe, rozmieszczone co $2 \mathrm{~km}$,

- automatyczne systemy monitorowania natężenia ruchu i warunków pogodowych oraz związane z nimi elektroniczne znaki, umożliwiajacce dynamiczne zmiany ograniczeń prędkości, a także ostrzeganie podróżnych przed utrudnieniami w ruchu,

- wcześniej przygotowane plany dróg objazdowych, w sytuacjach awaryjnych zamknięć odcinków autostrady.

Standardy budowy i projektu nieco różnią się na autostradach miejskich, nazywanych Stadtautobahn. Sa to drogi przeważnie zapewniające dostęp do miasta i komunikację w mieście, jednak w większości przypadków omijają one śródmieścia, np. autostrada A 100 w Berlinie stanowi śródmiejską obwodnicę i nie przechodzi przez to centrum. Autostrady na terenach zurbanizowanych posiadaja trzy lub cztery pasy ruchu w danym kierunku o wspomnianej już szerokości 3,5 m. Czasami nie sa przy nich umieszczane telefony alarmowe, a standardowe znaki sa zawieszane nad pasami, a nie ustawiane obok nich. W nocy

\footnotetext{
${ }^{16}$ www.gettingaroundgermany.info/autobahn.shtml [z dn. 31.10.2011].

17 Tamże.
} 
na większości miejskich autostrad używane jest sztuczne oświetlenie. Węzły na nich są rozmieszczone w dużo większej częstotliwości. Z powodu specyfiki terenu, na którym położone sa te drogi, częściej niż na autostradach pozamiejskich budowane sa wiadukty i tunele ${ }^{18}$.

W systemie autostradowym Niemiec używa się obecnie ponad 65 tuneli. Duży nacisk kładzie się na bezpieczeństwo, dlatego są one wyposażone w 24-godzinny monitoring wideo, radio z informacjami dla podróżnych, znaki elektroniczne, systemy oddymiania, wyjścia ewakuacyjne, oświetlenie awaryjne i tzw. pokoje schronienia, które sa wyekwipowane m.in. w telefony alarmowe i gaśnice ${ }^{19}$.

Przepisy obowiązujace na niemieckich autostradach maja na celu zapewnienie wysokiego stopnia bezpieczeństwa ich użytkowania. Nie maja na nie wstępu rowerzyści, motorowerzyści, piesi oraz pojazdy, które nie są w stanie rozwinąć prędkości co najmniej $60 \mathrm{~km} / \mathrm{h}$. Zatrzymywanie się, parkowanie i zawracanie są ściśle zabronione. Należy także pamiętać o odpowiednim zapasie paliwa, ponieważ zaparkowanie na pasie awaryjnym z powodu jego braku jest również złamaniem przepisu o niepotrzebnym zatrzymywaniu pojazdu. Wjazd na autostradę oraz zjazd z niej jest możliwy tylko i wyłącznie na wyznaczonych do tego celu węzłach autostradowych, a użytkownicy drogi włączający się do ruchu z pasów rozbiegowych musza ustapić pierwszeństwa pojazdom już znajdujacym się na autostradzie. Kierowcy poruszający się z niższymi prędkościami powinni korzystać z prawych pasów. Na autostradach co najmniej trójpasmowych pojazdy o masie powyżej 3,5 t lub z przyczepą nie moga korzystać z najdalszego lewego pasa. Manewr wyprzedzania powinien odbywać się z wykorzystaniem pasa po lewej stronie; użycie prawego pasa jest zabronione, poza sytuacjami, w których zaczyna się formować korek na drodze, kiedy można wyprzedzać z prawej strony, ale przy małej prędkości, jak też w przypadku korzystania z pasa rozbiegowego. W sytuacji kongestii użytkownicy na lewym pasie powinni przesunąć się możliwie najdalej $w$ lewą stronę, a na pasach środkowym i prawym - w swoja prawa stronę. Dzięki temu powstanie możliwość przejazdu dla pojazdów uprzywilejowanych. Jeżeli pojazd ulegnie awarii lub zdarzy się wypadek, kierowca jest zobligowany do zatrzymania się na pasie awaryjnym, ustawienia trójkąta ostrzegawczego w odległości $200 \mathrm{~m}$ od miejsca zdarzenia i wezwania pomocy przez telefon awaryjny ${ }^{20}$.

\footnotetext{
${ }^{18}$ www.german-autobahn.eu/index.asp?page =design [z dn. 31.10.2011].

${ }^{19}$ www.carazoo.com/article/0405200901/Autobahn---The-Mystique-Route [z dn. 31.10.2011].

${ }^{20}$ www.gettingaroundgermany.info/autobahn.shtml [z dn. 31.10.2011].
} 
Brak ograniczeń prędkości na niemieckich autostradach stał się już legendarny wśród kierowców na całym świecie. Jednakże to wyobrażenie, podobnie jak w przypadku oczekiwanych dwudziestu pasów ruchu, często okazuje się mylne, ponieważ dozwolona prędkość na wielu odcinkach jest ograniczona przez prawo ruchu drogowego. Najczęściej stosuje się limity z przedziału $80-130 \mathrm{~km} / \mathrm{h}$. Sporadycznie na odcinkach miejskich przepisy moga być bardziej restrykcyjne, a na terenach remontowych dozwolona jest prędkość nie wyższa niż $60 \mathrm{~km} / \mathrm{h}$. Niektóre odcinki posiadają ograniczenia nocne lub zależne od pogody, często powiązane z systemem znaków elektronicznych. Jednakże na ok. 2/3 niemieckich autostrad kierowcy moga poruszać się z dowolną prędkościa, oprócz pojazdów ciężarowych, które zawsze obowiązuje ograniczenie $80 \mathrm{~km} / \mathrm{h}$ lub niższe, wynikające z przepisów na danym odcinku. Niektóre moga być jednak zwolnione $z$ tego limitu. Informuje o tym oznaczenie przypominające znak ograniczenia z tyłu pojazdu z wpisaną liczba, która jest właśnie obowiązującym go limitem. W Niemczech istnieje specyficzne pojęcie "prędkości zalecanej" - na odcinkach bez restrykcji szybkości poruszania zaleca się (ale nie jest to żadne prawne ograniczenie) jazdę z nie więcej niż $130 \mathrm{~km} / \mathrm{h}$ na prędkościomierzu. Za przekroczenie tego limitu kierowca nie dostanie mandatu, ale może ponieść odpowiedzialność za szkody spowodowane wypadkiem, nawet jeżeli nie był on strona winna.

Utrzymanie tak rozbudowanej sieci autostrad jest bardzo skomplikowane. Okresowo sprawdza się każdy metr kwadratowy przy pomocy specjalnych pojazdów wyposażonych w system badający stan nawierzchni. Jeżeli zostaną wykryte pęknięcia lub inna wada, cały odcinek zostaje zamknięty i poddany naprawie. Stan oznakowania, barier i innych elementów również jest monitorowany, dzięki czemu są one dobrze utrzymane ${ }^{21}$. Pomimo wysokich kosztów konserwacji, autostrady pozostaja niepłatne dla pojazdów osobowych. Kierowcy ciężarówek ponoszą opłaty, które są naliczane od każdego przejechanego kilometra w wysokości zależnej od liczby osi i klasy silnika pod względem emisji spalin 22 . System opłat za autostrady został wprowadzony w Niemczech w 2005 r. i jest oparty na łączności satelitarnej. Był to pierwszy system tego typu wprowadzony Europie ${ }^{23}$.

21 Tamże.

22 www.uta.pl/autostrady_niemcy_2009.htm [z dn. 5.11.2011].

23 J. Neider, D. Marciniak-Neider, Transport multimodalny w Europie, Wyd. Uniwersytetu Gdańskiego, Gdańsk 2005, s. 105-106. 


\subsection{Charakterystyka sieci autostrad w aglomeracji berlińskiej}

System autostrad w aglomeracji berlińskiej liczy łącznie $307,5 \mathrm{~km}^{24}$ i jest skonstruowany $w$ interesujący sposób. Autostrada A 10, nazywana często Berliner Ring, przebiega wokół aglomeracji i stanowi jej zewnętrzną obwodnicę. Autostrada A 100, zwana potocznie Berliner Stadtring albo Stadtautobahn, znajduje się w całości na terenie Berlina i jest autostradową obwodnicą śródmieścia tego miasta. Pomimo członu "ring" (niem. pierścień) w nazwie, droga ta nie stanowi zamkniętego okręgu i jest obwodnica tylko południowej oraz zachodniej części centrum Berlina. Początkowo A 100 była zaprojektowana jako autostrada otaczająca całe śródmieście, ale obecnie ukończenie pierścienia nie jest planowane. Berliner Ring i Berliner Stadtring sa powiązane innymi autostradami: A 111 w północnej części, A 113 w południowej oraz A 115 na południowym zachodzie miasta. Także droga A 114 łączy Berliner Ring z centrum miasta, ale nie dochodzi ona do śródmiejskiej obwodnicy. W skład sieci autostrad aglomeracji berlińskiej wchodzą również autostrady oznaczone jako A 103 (znajdująca się w centrum miasta) oraz A 117 (będąca odnoga drogi A 113)

Najważniejszym elementem analizowanej sieci autostrad jest Berliner Ring - zewnętrzna obwodnica aglomeracji berlińskiej oznaczona symbolem A 10. Jej długość wynosi $196 \mathrm{~km}$ i otacza ona Berlin zamkniętym pierścieniem. W tab. 9 przedstawiono węzły autostradowe, w których Berliner Ring krzyżuje się z innymi autostradami. Koniec tej drogi jest zarazem jej kilometrem zerowym (początkowym), co ma miejsce w północnej części pierścienia, w węźle "Schwanebeck". W węzłach "Schönefelder Kreuz", "Nuthetal”, "Oranienburg" oraz „Pankow" od A 10 odchodza odpowiednio autostrady A 113, A 115, A 111 oraz A 114, które stanowia połączenie z centrum Berlina. Z obwodnica niemieckiej stolicy krzyżują się również autostrady umożliwiające dojazd do innych obszarów Niemiec, jak przykładowo autostrada A 24 prowadząca do Hamburga, krzyżująca się z A 10 w węźle "Havelland". Na trasie Berliner Ringu znajduje się łącznie 36 węzłów autostradowych ${ }^{26}$.

Berliner Ring przebiega przez 15 mostów, których łączna długość wynosi ok. $3111 \mathrm{~m}$. Najdłuższy z nich, znajdujący się pomiędzy węzłami autostradowymi nr 5 i 6, most nad Mühlenfließ mierzy 742 m,

\footnotetext{
${ }^{24}$ www.autobahnatlas-online.de/Strecken.htm [z dn. 5.11.2011].

${ }^{25}$ www.berlin-life.com/travel/travel.php [z dn. 5.11.2011].

${ }^{26}$ www.autobahnatlas-online.de/A10.htm [z dn. 5.11.2011].
} 
a most nad Hawela, położony na odcinku pomiędzy 23. i 24. węzłem, ma długość $704 \mathrm{~m}$. Aby zapewnić podróżnym korzystającym z autostrady A 10 komfort jej użytkowania na odpowiednio wysokim poziomie, przy trasie rozmieszczono trzy miejsca obsługi podróżnych, w których istnieje również możliwość zatankowania, znajdujące się na 13., 58. oraz 92. kilometrze drogi. Podróżni moga uzupełnić swój zapas paliwa również na stacji benzynowej na 150. i 152. kilometrze autostrady. Do ich użytku dostępnych jest również 12 parkingów (trzy są dostępne tylko z jednego kierunku jazdy), z których dwa, umiejscowione na 134. i 177. kilometrze, sa obecnie rozbudowywane do standardu miejsc obsługi podróżnych. Na wielu odcinkach Berliner Ringu nie znajdują się żadne ograniczenia prędkości, co oznacza, że użytkownicy drogi mogą podróżować z dowolną szybkością. Zachodni odcinek A 10 między węzłami nr 21 "Werder" oraz 29 "Havelland" jest najdłuższym, na którym dopuszczalna prędkość jest stale obniżona przez przepisy, przeważnie pozwalające na jazdę z maksymalnie $120 \mathrm{~km} / \mathrm{h}$ na liczniku. Dopuszczalna szybkość ruchu rzadko jest ograniczana poniżej $100 \mathrm{~km} / \mathrm{h}$, jednak incydentalne ma to miejsce, przykładowo w węźle nr 29 "Havelland”, gdzie jest ona ograniczona do $60 \mathrm{~km} / \mathrm{h}^{27}$.

Tabela 9. Węzły autostradowe A 10, w których ma miejsce krzyżowanie się autostrad

\begin{tabular}{|r|l|c|c|l|}
\hline $\begin{array}{c}\text { Nr } \\
\text { węzła }\end{array}$ & \multicolumn{1}{|c|}{ Nazwa węzła } & Kilometr A 10 & $\begin{array}{c}\text { Nr autostrady } \\
\text { krzyżującej się z A 10 }\end{array}$ & \multicolumn{1}{|c|}{ Kierunek } \\
\hline 1. & Schwanebeck & 0,0 & A 11 & Szczecin \\
\hline 8. & Spreeau & 40,5 & A 12 & Frankfurt \\
\hline 11. & Schönefelder Kreuz & 54,0 & $\begin{array}{c}\text { A 13 } \\
\text { A 113 }\end{array}$ & $\begin{array}{l}\text { Drezno } \\
\text { Berlin }\end{array}$ \\
\hline 16. & Nuthetal & 86,8 & A 115 & Berlin \\
\hline 19. & Potsdam & 98,9 & A 9 & Lipsk, Monachium \\
\hline 21. & Werder & 107,8 & A 2 & $\begin{array}{l}\text { Magdeburg, } \\
\text { Zagłębie Ruhry }\end{array}$ \\
\hline 29. & Havelland & 155,0 & A 24 & Hamburg \\
\hline 31. & Oranienburg & 167,5 & A 111 & Berlin \\
\hline 35. & Pankow & 185,9 & A 114 & Berlin \\
\hline
\end{tabular}

Źródło: opracowanie własne.

Kolejnym istotnym elementem sieci autostrad aglomeracji berlińskiej jest autostrada A 100, nazywana Berliner Stadtring albo Stadtautobahn, która pełni rolę obwodnicy południowej i zachodniej części

27 Tamże. 
centrum Berlina. Mierzy ona $21 \mathrm{~km}$ długości. Na jej trasie wyznaczonych zostało 26 węzłów autostradowych, poczynając od znajdującego się w półocno-zachodnim krańcu Stadtringu "Seestraße" do węzła nr 26 "Grenzallee", który jest oznaczony jako "prowizoryczny". A 100 jest połączona z Berliner Ringiem trzema autostradami: A 111 odchodząca od Stadtringu na północ, A 115 znajdująca się w południowo-zachodniej części Berlina oraz A 113, przebiegająca przez południowo-wschodnie rejony aglomeracji. A 111 dołącza do A 100 na jego 3. kilometrze, w węźle nr 4 "Charlottenburg”. W węźle nr 10 „Funkturm”, położnym 4 km dalej, ma miejsce połączenie Stadtringu z A 115. Natomiast autostrada A 113 włącza się do niego w węźle nr 25 "Neukölln", znajdującym się na 21. kilometrze trasy. W węzłach $\mathrm{nr} 14$ "Schmargendorf" znajdujacym się na 10. kilometrze drogi oraz oddalonym o 8 km "Gradestraße" (nr 22) od Stadtringu odchodza jego odnogi, o długości odpowiednio 2,6 i 1,1 km. Dawniej były to samodzielne autostrady, oznaczone jako A 104 i A 102, jednak zostały one scalone z A 100 w 2006 r. Na 13. kilometrze opisywanej drogi znajduje się węzeł "Schöneberg" (nr 18), w którym ma miejsce skrzyżowanie autostrad A 100 i A $103^{28}$.

Autostrada A 100 znajduje się w centrum Berlina, co znacznie utrudniło pracę jej projektantom i konstruktorom. Na jej trasie jest 11 mostów o łącznej długości 3286 m. Najdłuższy z nich, Rudolf-Wissell-Brücke, mierzy aż $926 \mathrm{~m}$. Konieczne było także wybudowanie trzech tuneli, łącznie mierzących 2057 m długości, z czego większość stanowi tunel "Ortskern Britz" o długości 1713 m. Przy Berliner Stadtringu znajduje się też jedno miejsce obsługi podróżnych nazwane "Avus", na terenie którego mieści się stacja benzynowa. Jest ono dostępne również z autostrady A 115. Na autostradzie A 100 najwyższą dozwoloną szybkością poruszania się pojazdów jest $80 \mathrm{~km} / \mathrm{h}$, jednakże na wielu odcinkach znajduje się ograniczenie do niższych prędkości ${ }^{29}$.

Z A 100 ściśle powiązana jest inna śródmiejska autostrada, mająca oznaczenie A 103, często nazywana Westtangente Steglitz. Mierzy ona 3,7 km długości i łączy Berliner Stadtring z Rondem Steglickim. Na jej trasie znajduja się trzy mosty o zsumowanej długości $580 \mathrm{~m}$ oraz jeden tunel o długości 260/227 m (różne długości po przeciwnych pasach ruchu). Najwyższa dozwolona prędkość to $80 \mathrm{~km} / \mathrm{h}$, jednakże w paru miejscach użytkownicy drogi podlegaja ograniczeniu prędkości nawet do $40 \mathrm{~km} / \mathrm{h}^{30}$.

\footnotetext{
28 http://www.autobahnatlas-online.de/A100.htm [z dn. 5.11.2011].

29 Tamże.

${ }^{30}$ www.autobahnatlas-online.de/A103.htm [z dn. 5.11.2011].
} 
Autostrada A 111 mierzy 22,6 km i znajduje się w północno-zachodniej części aglomeracji berlińskiej. Stanowi ona połączenie Berliner Ringu z Berliner Stadtringiem. Na jej trasie znajduje się 13 węzłów autostradowych. W pierwszym z nich, nazwanym "Oranienburg”, następuje włączenie A 111 do A 10. W węźle nr 7 "Kurt-Schumacher-Platz" na 19. kilometrze autostrady A 111 ma miejsce jej rozgałęzienie. Jedna odnoga zmierza w kierunku centrum miasta, druga zaś to dawna autostrada A 105, o długości 1,4 km, scalona z opisywaną drogą w 2006 r. W ostatnim, trzynastym węźle "Charlottenburg" (22,6 km) A 111 łączy się z Berliner Stadtringiem ${ }^{31}$.

Na trasie autostrady A 111 znajduja się 4 mosty o łącznej długości 335 m oraz 6 tuneli mierzących razem 2551/2604 m (zależnie od kierunku pasa ruchu). Dostępne dla użytkowników jest jedno miejsce obsługi podróżnych, posiadające stację benzynową. Na około 9-kilometrowym północnym odcinku A 111 maksymalna dozwolona prędkość nie jest poddana żadnym ograniczeniom. Jednak od 10. kilometra kierowcy muszą zwolnić do $60 \mathrm{~km} / \mathrm{h}$ i aż do końca tej drogi najwyższa dopuszczalna przepisami szybkość poruszania się jej użytkowników wynosi maksymalnie $80 \mathrm{~km} / \mathrm{h}^{32}$.

Autostrada A 113, znajdująca się w południowo-wschodniej części aglomeracji berlińskiej, liczy 19,1 km długości. Opisywana droga stanowi łącznik pomiędzy A 100 oraz A 10, z którymi krzyżuje się odpowiednio w węzłach nr 1 "Neukölln" oraz ostatnim 10. "Schönefelder Kreuz", po którym przechodzi w autostradę A 13. W 9. węźle "Waltersdorf" od A 113 odchodzi autostrada A $117^{33}$.

Trasa autostrady A 113 przebiega po 6 mostach o łącznej długości $565 \mathrm{~m}$. Wykorzystane są również dwa tunele, mierzące razem $1208 \mathrm{~m}$ długości. Przy opisywanej drodze nie zostały wyznaczone żadne miejsca obsługi podróżnych, nie ma także ani jednej stacji benzynowej. W południowym odcinku autostrady A 113 można rozwinąć prędkość nie więcej niż $120 \mathrm{~km} / \mathrm{h}$. W dalszej części, bliżej centrum miasta, przepisy pozwalają na podróż z maksymalną szybkościa $80 \mathrm{~km} / \mathrm{h}^{34}$.

Autostrada A 117 jest odnoga autostrady A 113 i liczy 4,8 km długości. Posiada ona trzy węzły autostradowe. W pierwszym z nich, nazwanym "Waltersdorf", ma miejsce rozwidlenie A 117 oraz A 113. Przy opisywanej autostradzie znajduje się jedna stacja benzynowa. Na większości tej trasy dozwolona prędkość maksymalna wynosi $100 \mathrm{~km} / \mathrm{h}$,

\footnotetext{
${ }^{31}$ www.autobahnatlas-online.de/A111.htm [z dn. 5.11.2011].

32 Tamże.

${ }^{33}$ www.autobahnatlas-online.de/A113.htm [z dn. 5.11.2011].

34 Tamże.
} 
jednakże w paru miejscach jest ona jeszcze bardziej ograniczona, najwięcej do $40 \mathrm{~km} / \mathrm{h}^{35}$.

Autostrada A 114, znajdująca się na północy Berlina, łączy zewnętrzną obwodnicę A 10 8,5-kilometrowym odcinkiem z centrum miasta. Nie dochodzi ona jednak do śródmiejskiej obwodnicy A 100. Na jej trasie wyznaczone jest pięć węzłów. W pierwszym z nich, nazwanym „Pankow”, ma miejsce skrzyżowanie A 114 oraz Berliner Ringu. Opisywana autostrada kończy się w węźle nr 5 "Prenzlauer Promenade", od którego dalej odchodzi w stronę centrum droga B 109. Na trasie A 114 znajdują się dwa mosty o łącznej długości 390 m (380 m jadąc od centrum miasta) ${ }^{36}$.

$\mathrm{Na}$ autostradzie A 114 dozwolona maksymalna prędkość wynosi $80 \mathrm{~km} / \mathrm{h}$; takie ograniczenie obowiązuje przez 7,6 km trasy od strony Berliner Ringu. W południowej części, na ostatnim kilometrze przepisy ograniczają szybkość prowadzenia pojazdów do $70 \mathrm{~km} / \mathrm{h}^{37}$.

Autostrada A 115 znajduje się w południowo-zachodnim regionie aglomeracji berlińskiej. Łączy ona Berliner Stadtring i Berliner Ring 28,1-kilometrowym odcinkiem, mając skrzyżowania z tymi autostradami w węzłach odpowiednio nr 1 "Funkturm" oraz nr 9 "Nuthetal", który jest jej ostatnim węzłem ${ }^{38}$.

Dla podróżnych dostępny jest parking oraz dwa miejsca obsługi podróżnych, z czego jedno z nich, o nazwie "Avus", jest osiagalne również $z$ autostrady A 100. Trasa A 115 przebiega po dwóch mostach, mających razem 130 m długości. Na południowym, 15-kilometrowym odcinku tej autostrady przepisy ograniczają szybkość ruchu do $120 \mathrm{~km} / \mathrm{h}$. Jednakże im bliżej centrum miasta, tym dozwolona prędkość maksymalna ulega obniżeniu, nawet do $60 \mathrm{~km} / \mathrm{h}$ w północnej części ${ }^{39}$.

\section{Podsumowanie}

W wyniku analiz przeprowadzonych w niniejszym rozdziale sformułowano następujące wnioski:

- Sieć autostrad w aglomeracji berlińskiej znacząco wspomaga system transportowy stolicy Niemiec i całego obszaru Brandenburgii.

\footnotetext{
${ }^{35}$ www.autobahnatlas-online.de/A117.htm [z dn. 6.11.2011].

${ }^{36}$ www.autobahnatlas-online.de/A114.htm [z dn. 6.11.2011].

37 Tamże.

${ }^{38}$ www.autobahnatlas-online.de/A115.htm [z dn. 6.11.2011].

39 Tamże.
} 
Autostrada A 10, czyli Berliner Ring, będący zewnętrzną autostradową obwodnica zespołu miejskiego, umożliwia pojazdom ominięcie obszaru aglomeracji i przejmuje ciężar międzymiastowego ruchu tranzytowego. Autostrady, które stanowią połączenie obwodnicy z centrum miasta, polepszaja komunikację w aglomeracji, a Berliner Stadtring (autostrada A 100) usprawnia funkcjonowanie transportu w samym śródmieściu.

- Podobne rozwiązania do wprowadzonych w aglomeracji berlińskiej zostały zastosowane również $w$ innych miastach. Można zauważyć znaczące podobieństwa pomiędzy niemiecką autostradą A 10 a m.in.: Boulevard Périphérique w Paryżu ${ }^{40}$, moskiewską MKAD ${ }^{41}$ oraz autostrada M25 stanowiąca obwodnicę Londynu ${ }^{42}$. W Polsce szanse na rozwiązanie infrastrukturalne zbliżone do Berliner Ringu ma obszar aglomeracji łódzkiej, gdzie planowana jest obwodnica stanowiąca zamknięty pierścień, składająca się z autostrad A1 i A2, znajdujących się odpowiednio we wschodnim i północnym obszarze aglomeracji, oraz dróg ekspresowych S8 i S14, będących obwodnicami południowej i zachodniej części zespołu miejskiego ${ }^{43}$. Przykład Berliner Ringu pokazuje, że jest to dla Łodzi i całego jej regionu projekt niezwykle istotny.

${ }^{40}$ http://en.wikipedia.org/wiki/Boulevard_P\%C3\%A9riph\%C3\%A9rique [z dn. 6.11.2011].

${ }^{41}$ http://en.wikipedia.org/wiki/MKAD [z dn. 6.11.2011].

42 http://en.wikipedia.org/wiki/M25_motorway [z dn. 6.11.2011].

${ }^{43}$ Rozporządzenie Rady Ministrów z dnia 20 października 2009 r. zmieniające rozporzadzenie w sprawie sieci autostrad i dróg ekspresowych, Dz.U. z 2009 r., nr 187, poz. 1446. 



\section{Realizacja ciężkiego tranzytu kołowego przez aglomerację tódzką}

Damian Michalski*

\subsection{Specyfika aglomeracji łódzkiej}

"Aglomeracja jest to skupisko ludności i zabudowy na małym obszarze, powodujące jego silne zurbanizowanie" ${ }^{11}$. To złożony organizm, w którego skład wchodza miasta i osiedla powiązane ze sobą licznymi funkcjami oraz przejawiajace tendencje do integracji. Tworza zespół miejski², który "jest zarówno specyficznym układem przestrzenno-strukturalnym, jaki i wielowarstwowa struktura przestrzenna o określonym położeniu, organizacji przestrzennej i funkcjonowaniu"3.

Aglomeracja łódzka jest z jednym najliczniejszych systemów miejskich naszego kraju. Z liczbą przeszło miliona mieszkańców ustępuje tylko aglomeracji górnośląskiej ( 3 mln mieszkańców) i warszawskiej (2,6 mln mieszkańców). Co więcej, aglomeracja łódzka zalicza się do typu aglomeracji monocentrycznej, w której centrum znajduje się ośrodek miejski (rdzeń), zaś wokoło są przyrośnięte miasta satelitarne oraz zurbanizowane wsie. Z czasem strefa podmiejska może być wchłonięta przez rozrastające się miasto i staje się jego integralną częścią. Taki typ aglomeracji powstaje, gdy jedno z miast posiada wyższą rangę i większą powierzchnię od innych, które je otaczaja4.

*Mgr Damian Michalski - Katedra Logistyki, Wydział Zarządzania Uniwersytetu Łódzkiego, ul. Matejki 22/26, 90-237 Łódź.

${ }^{1}$ Encyklopedia Popularna PWN, Warszawa 1996, s. 17.

2 M. Szymczak, Logistyka miejska, Wyd. Akademii Ekonomicznej w Poznaniu, Poznań 2008, s. 17.

3 J. Parysek, Aglomeracje miejskie w Polsce oraz problemy ich funkcjonowania i rozwoju, [w:] J. Parysek, A. Tolle (red.), Wybrane problemy rozwoju i rewitalizacji miast: aspekty poznawcze i praktyczne, Biuletyn Instytutu Geografii Społeczno-Ekonomicznej i Gospodarki Przestrzennej Uniwersytetu im. Adama Mickiewicza w Poznaniu, Poznań 2008, za: http://www.rr.amu.edu.pl/files/RR_05_04.pdf.

${ }^{4}$ http://pl.wikipedia.org/wiki/Aglomeracja_monocentryczna [z dn. 30.10.2011]. 


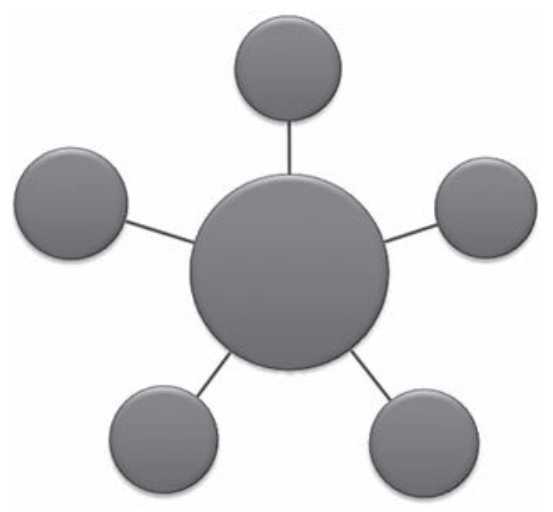

Rysunek 6. Schemat aglomeracji monocentrycznej

Źródło: opracowanie własne

Łódź jest właśnie takim głównym miastem - rdzeniem, naokoło którego funkcjonują i rozwijaja się mniejsze ośrodki miejskie. W odniesieniu do definicji aglomeracji monocentrycznej, na rys. 7 przedstawiona została aglomeracja łódzka według wspomnianego schematu.

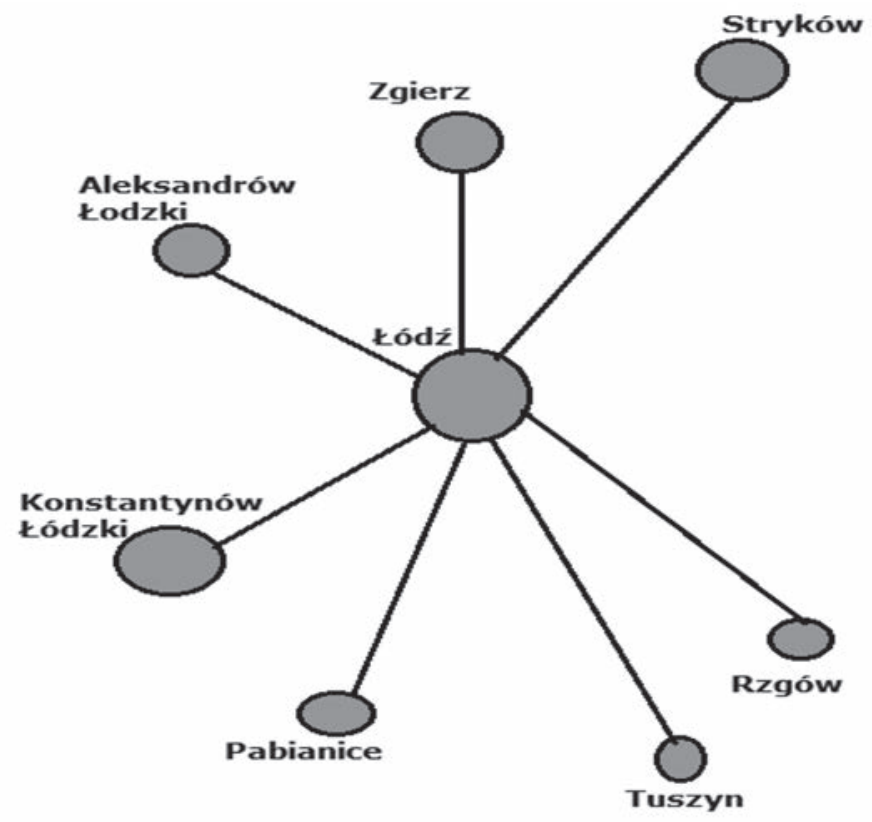

Rysunek 7. Aglomeracja łódzka - aglomeracją monocentryczną Źródło: opracowanie - Anna Zmysłowska 
W skład aglomeracji łódzkiej wchodzi miasto Łódź, Pabianice, Zgierz, Aleksandrów Łódzki, Konstantynów Łódzki, Rzgów, Stryków, Brzeziny, Tuszyn, Koluszki i Głowno. Do tego zespołu miejskiego należałoby także włączyć miasto, które jest znacznie oddalone od Łodzi. Między nim a "rdzeniem" istnieje połączenie linią tramwajowa, co tym bardziej skłania do uznania go za miasto satelitarne Łodzi. Chodzi tu o Ozorków. Co ciekawe, linia tramwajowa z łódzkich Chocianowic do Ozorkowa jest najdłuższą linią tramwajowa w Polsce - długość trasy to $34 \mathrm{~km}$.

Tabela 10. Ludność aglomeracji łódzkiej

\begin{tabular}{|l|c|}
\hline \multicolumn{1}{|c|}{ Miasto } & Ludność \\
\hline Łódź & 747200 \\
\hline Pabianice & 69500 \\
\hline Zgierz & 58100 \\
\hline Aleksandrów Łódzki & 20700 \\
\hline Ozorków & 20400 \\
\hline Konstantynów Łódzki & 17600 \\
\hline Głowno & 14900 \\
\hline Koluszki & 13300 \\
\hline Brzeziny & 12300 \\
\hline Tuszyn & 7200 \\
\hline Stryków & 3600 \\
\hline Rzgów & 3400 \\
\hline
\end{tabular}

Źródło: opracowanie własne na podstawie: Rocznik Statystyczny Rzeczypospolitej Polskiej 2009, Zakład Wydawnictw Statystycznych, Warszawa 2009, s. 205.

Główną przyczyną powstania, formowania i rozwoju aglomeracji łódzkiej był przemysł włókienniczy oraz jego intensywny rozwój w XIX i początku XX wieku. Ta część gospodarki była kołem zamachowym dla miasta, najważniejszym i największym źródłem dochodu. Nie zawsze za dynamicznym tempem rozwoju urbanizacji regionu łódzkiego były w stanie nadążyć zmiany społeczne oraz rozbudowa bazy materialnej miast. Łódź i jej aglomeracja zalicza się do tej części kraju, która bardzo dotkliwe odczuła kryzys gospodarczy lat 80. i 90. Restrukturyzacja gospodarki przebiegała bardzo powoli, z dużymi utrudnieniami. 
Ostatnimi laty Łódź cieszy się coraz to większym zainteresowaniem przedsiębiorców i z każdym rokiem przybywa inwestycji w tym regionie. W końcu wystartował proces rewitalizacji i ponownego zagospodarowania poprzemysłowych terenów i budynków fabrycznych (C.H. Manufaktura, Hotel Andel's w dawnej „Przędzalni” zakładów Poznańskiego, lofty w dawnej fabryce Scheiblera). Tej pozytywnej tendencji towarzyszy uruchomienie lotniska oraz kolejne inwestycje z nim związane, a także wiele innych, jak np. oddanie do użytku największej hali widowiskowo-sportowej Arena czy największego centrum handlowego - Portu Łódź. Wszystko to sprzyja dynamicznemu rozwojowi miasta i regionu oraz przemianom strukturalnym aglomeracji ${ }^{5}$.

Oczywiście, z każdą nową inwestycją związane są wprost proporcjonalne wzrosty natężenia ruchu samochodowego, zwiększenie tranzytu przez aglomerację. To przekłada się na zatłoczenie tras przelotowych. Wszystkie te czynniki maja znaczący wpływ na jakość życia w mieście i jakość podróżowania przez aglomerację.

\subsection{Aktualny stan tranzytu kołowego przez aglomerację tódzką}

Transport samochodowy odbywa się przez aglomerację łódzką bez przerwy. Komunikacja miejska przy użyciu autobusów i tramwajów każdego dnia przewozi setki tysięcy pasażerów. Ludzie dojeżdżaja do pracy i domów także samochodami, a ładunki sa przewożone przez miasto ciężarówkami. Wszystko to daje tysiące osób i setki tysięcy ton ładunków transportowanych przez arterie miejskie, które są zarazem trasami tranzytowymi przez aglomerację.

Pojęcie tranzytu samochodowego jest pojęciem zdecydowanie bardziej uściślającym, ale mieszczącym się w granicach pojęcia transportu samochodowego. "Tranzyt jest to przewóz osób lub ładunków przez określony obszar danego kraju lub z jednego państwa do drugiego przez terytorium trzeciego państwa, dokonywany na określonych warunkach" ${ }^{\prime 6}$. Tranzyt można podzielić na7:

- bezpośredni - gdy towar transportowany jest przez obszar kraju bez prawa składowania (rys. 8)

${ }^{5}$ J. Parysek, Aglomeracje miejskie w Polsce...

${ }^{6}$ Słownik wyrazów obcych, PWN, Warszawa 1980, s. 772.

7 M. Hajdul, Przewozy tranzytowe, [w:] M. Stajniak, M. Hajdul, M. Foltyński, A. Krupa, Transport i spedycja, Instytut Logistyki i Magazynowania, Poznań 2007, s. 83. 


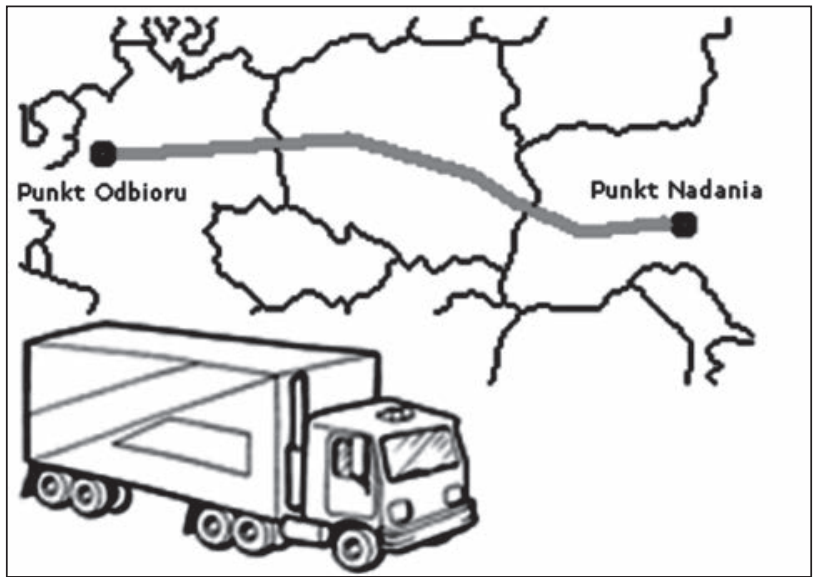

Rysunek 8. Tranzyt bezpośredni

Źródło: M. Hajdul, Przewozy tranzytowe, [w:] M. Stajniak, M. Hajdul, M. Foltyński, A. Krupa, Transport i spedycja, Instytut Logistyki i Magazynowania, Poznań 2007, s. 83

- pośredni - gdy towary są składowane przez określony czas na terytorium kraju tranzytowego, przepakowywane lub przeładowywane (rys. 9)

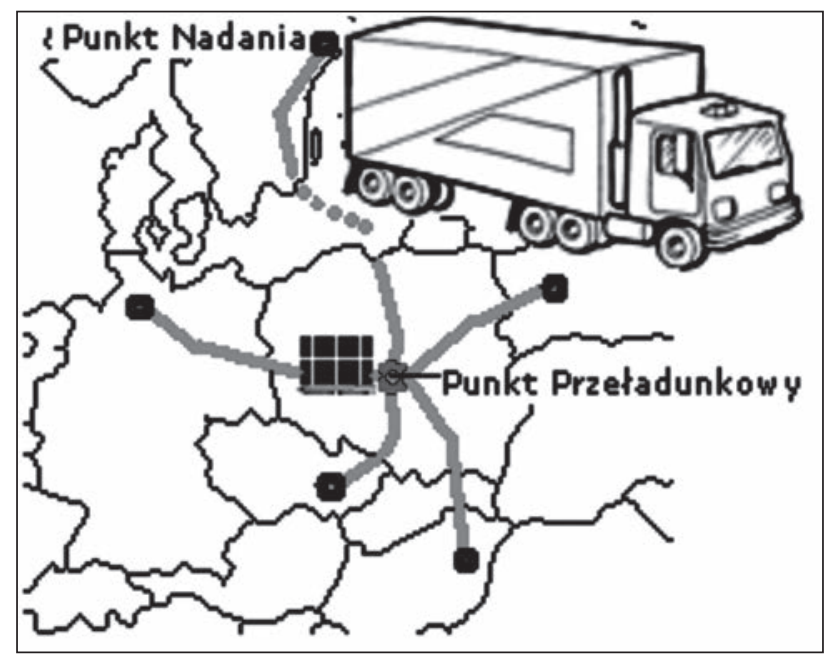

Rysunek 9. Tranzyt pośredni

Źródło: jak do rys. 8.

Zgodnie z definicja, z tranzytem mamy do czynienia także wówczas, gdy transport ładunków odbywa się tylko w obszarze jednego państwa. W przypadku aglomeracji łódzkiej wszystkie wymienione rodzaje 
tranzytu maja miejsce. Biegna przez nia dwa europejskie korytarze transportowe: II korytarz z zachodu na wschód - poziomy i VI korytarz z północy na południe - pionowy.

Szczególny wpływ na zatłoczenie motoryzacyjne aglomeracji łódzkiej ma korytarz pionowy, pokrywający się z trasą krajową nr 1, który ma być zastapiony planowaną autostradą $A 1$. Ma ona omijać Łódź od strony wschodniej. Dzięki przedłużeniu autostrady A2 aż do Strykowa, cały tranzyt poziomego korytarza omija serce aglomeracji i jest kierowany na Poznań (kierunek zachód), Brzeziny lub Łowicz w kierunku Warszawy (kierunek wschód).

Niestety, ciężki transport samochodowy prowadzony korytarzem pionowym nie ma już możliwości ominięcia aglomeracji łódzkiej, a - co gorsza - uniknięcia wjazdu do miasta Łodzi. Na chwilę obecna nie istnieje żadna obwodnica, pozwalająca samochodom ciężarowym i osobowym na szybki przejazd przez aglomerację bez planowanego postoju w Łodzi. Problemy zaczynają się na drodze krajowej nr $1 \mathrm{w}$ miejscowości Emilia, czyli na skrzyżowaniu "jedynki" z autostradą A2. Wjazd do Zgierza poprzecinany jest skrzyżowaniami z sygnalizacja, przejściami dla pieszych, wjazdami i wyjazdami gospodarczymi oraz fotoradarami. W związku z tym, że prawie cała trasa tranzytu odbywa się przez obszar zabudowany, dopuszczalna prędkość oscyluje w granicach $50-70 \mathrm{~km} / \mathrm{h}$, a to dyskwalifikuje tę trasę jako szybką drogę przelotową.

Tabela 11. Znaki drogowe uzupełniające, kierujące tranzyt samochodowy

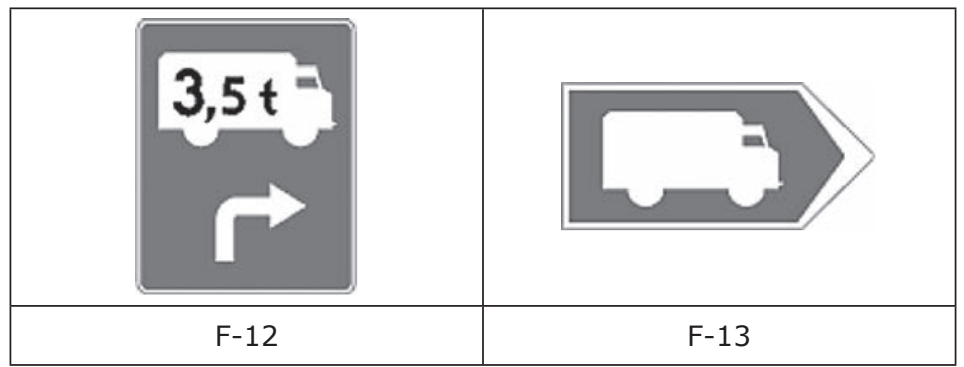

Źródło: niemiecki kodeks drogowy, za: http://www.kodeksdrogowy.com.pl/pobierz/ zagraniczne/kod_niemcy\%28Strassenverkehrs-Ordnung\%29.pdf [z dn. 15.10.2012].

Kierowców wjeżdżających do Łodzi znaki uzupełniające F-12 i F-13 kierują na Katowice największą łódzką arterią, czyli trasą zachodnią. Prowadzi ona aleja Włókniarzy i Jana Pawła II aż do ulic Pabianickiej, Paderewskiego i Rzgowskiej. Wraz opuszczeniem granic miasta zamienia się w trasę katowicka, a dalej w jedyny istniejący w tej części kraju 
21-kilometrowy odcinek autostrady A1. Możliwość przejazdu przez Łódź daję też trasa wschodnia, czyli zjazd z autostrady w Strykowie. Z tej trasy moga także korzystać kierowcy wjeżdżajacy od Zgierza. W tym celu, po wjeździe do Łodzi, kierują się ulicami Łagiewnicką i Inflancką, aż do wjazdu ze Strykowa. Dojazd do Łodzi z węzła autostradowego w Strykowie wygląda podobnie, jak w przypadku dojazdu do Zgierza. Jest to jednojezdniowa droga w obszarze zabudowanym wraz z przejściami dla pieszych, wjazdami gospodarczymi, z częstymi ograniczeniami prędkości i zakazami wyprzedzania. Tranzyt kierowany jest na Katowice arteriami: Strykowską, Palki i Rydza Śmigłego, aż do ulic Paderewskiego i Rzgowskiej, gdzie pokrywa się z trasą zachodnią.

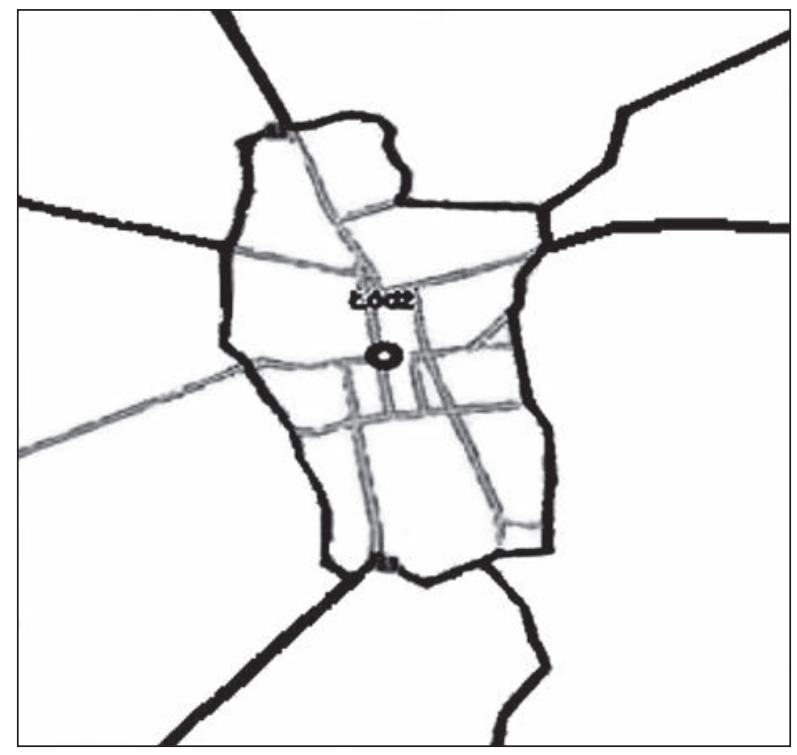

Rysunek 10. Tranzyt przez miasto Łódź

Źródło: opracowanie - Anna Palczewska

W celu dokonania charakterystyki tranzytu przez aglomerację, należy określić punkty startu i zakończenia tras tranzytowych. Biorąc pod uwagę planowane inwestycje drogowe, można uznać, że punktem, w którym cały ciężki tranzyt kołowy zostaje skierowany na Łódź, będą węzły autostradowe w Strykowie i Emilii oraz planowany węzeł drogi ekspresowej S8 z autostrada A1 w Rzgowie. Te trzy miejscowości sa traktowane jako punkt startu bądź zakończenia trasy tranzytowej przez aglomerację łódzka. 
Tabela 12. Charakterystyka tras tranzytowych

\begin{tabular}{|l|c|c|}
\hline \multicolumn{1}{|c|}{ Trasa z/na } & $\begin{array}{c}\text { Długość } \\
(\mathrm{km})\end{array}$ & $\begin{array}{c}\text { Czas* } \\
(\mathrm{min})\end{array}$ \\
\hline Zachodnia (Stryków/Rzgów) & 33,2 & 46 \\
\hline Wschodnia (Emilia/Rzgów) & 35,9 & 44 \\
\hline
\end{tabular}

${ }^{*}$ Czas uwzględnia tylko odległość i prędkość dopuszczalną na trasie. Nie uwzględnia postojów na światłach, kolejek do nich i korków ulicznych.

Źródło: opracowanie własne.

\subsection{Utrudnienia w przejeździe przez aglomerację łódzką}

Wszystkie systemy tranzytowe borykają się z szeregiem problemów. Dotyczą one przede wszystkim przeciążenia dróg oraz braku obwodnic, co powoduje konieczność obsługi tranzytu przez centra miast. Pogarsza to warunki życia w mieście, powiększa hałas i zanieczyszczenie powietrza ${ }^{8}$. Przy omawianiu tematu związanego z utrudnieniami towarzyszacymi przejazdom przez miasto, nie sposób pominąć pojęcia kongestii. Termin kongestia odnosi się do skupienia, nagromadzenia, zatłoczenia lub przeciążenia. Kongestia w transporcie zachodzi wówczas, gdy użytkowników drogi jest więcej niż maksymalna przepustowość danej drogi. Zjawisko to występuje powszechnie $w$ transporcie, a przejawia się w tworzeniu korków oraz zatorów ulicznych ${ }^{9}$.

Takim samym problemom musi stawić czoła aglomeracja łódzka. Brak obwodnic, wiaduktów, niska jakość techniczna dróg, korki i ciągle remonty dotycza systemu tranzytowego miasta Łodzi i miast satelitarnych.

W odniesieniu do obecnego systemu tranzytowego przez aglomerację łódzką obserwuje się utrudnienia, które znacznie wydłużają czas przejazdu przez ten system miejski. Lokalne ograniczenia przepustowości, nazywane "wąskimi gardłami”, występuja w sytuacji, gdy natężenie ruchu napływającego do danego punktu (drogi, skrzyżowania, mostu, przejazdu kolejowego itp.) jest większe, niż natężenie ruchu od tego punktu odpływającego ${ }^{10}$. Pierwszym takim „wąskim gardłem” trasy tran-

${ }^{8}$ B. Tundys, Logistyka miejska - koncepcje, systemy, rozwiązania, Difin, Warszawa 2008, s. 124.

${ }^{9}$ M. Szymczak, Logistyka miejska, s. 133.

${ }^{10}$ T. Dybicz, Wykrywanie lokalnych ograniczeń przepustowości w sieci drogowej, [w:] M. Kaczmarek, A. Krycha (red.), Skuteczne zmniejszanie zatłoczenia miast, Wyd. i Drukarnia UNI-DRUK, Poznań 2009, s. 375. 
zytowej jest przejazd Zgierz w kierunku Łodzi. Z dwóch jezdni, po dwa pasy ruchu w każdym kierunku, na ulicy Amii Krajowej, zostaje jedna jezdnia ulicy Łódzkiej, po jednym pasie w każdym kierunku. Podobna sytuacja ma miejsce przy wyjeździe z Łodzi w kierunku Zgierza. Ulica Zgierska na wysokości zajezdni tramwajowej "Helenówek" zwęża się do jednego pasa z dwupasmowej dwujezdniowej drogi. Co więcej, znajduje się tam sygnalizacja świetlna, która jest jednym z poważniejszych czynników hamujących płynność ruchu drogowego. W godzinach szczytu, w każdy roboczy dzień tygodnia, w punktach tych tworzą się niebotycznych rozmiarów korki z samochodów osobowych i ciężarówek przemieszczających się po trasie tranzytowej. Niekiedy pokonanie odcinka od ronda "Biłka" do Zgierza zajmuje 40 minut, a jest to trasa o długości niespełna 3,5 km.

W Zgierzu problemów doświadczaja kierowcy próbujący dotrzeć do węzła Emilia. Tu korek zaczyna się już na trasie Łęczyckiej, aż do samego ronda przy węźle, na odcinku 6,3 km. Przyczyna takiego stanu rzeczy są światła na skrzyżowaniach i przejściach dla pieszych oraz powstanie centrum logistycznego DPD, do którego ustawiają się kolejki samochodów ciężarowych, blokując trasę przejazdu.

Podobnym wąskim gardłem jest skrzyżowanie ulic Paderewskiego, Broniewskiego i Rzgowskiej w Łodzi, gdzie łączą się dwie trasy tranzytowe - wschodnia i zachodnia. W tym miejscu dwa pasy samochodów ciężarowych z trasy wschodniej i dwa pasy samochodów ciężarowych z trasy zachodniej wjeżdżaja w ulicę Rzgowską w celu wyjazdu z Łodzi na trasę katowicką. Towarzyszy temu sygnalizacja oraz ruch tramwajowy.

Newralgiczne punkty $w$ Łodzi stanowia dwa największe skrzyżowania, które nie sa przygotowane na przepływ tak dużej liczby pojazdów. Sa to skrzyżowania alei Włókniarzy z ulica Legionów oraz alei Piłsudskiego i Rydza-Śmigłego. Przejazd przez to skrzyżowanie potrafi zajać 10 zmian cyklów sygnalizacji świetınej dla jednego kierunku jazdy, co w przełożeniu na czas powoduje opóźnienie ok. 20-30 min.

Obecnie przejeżdżając przez aglomerację łódzką trasą zachodnią, o długości 33,2 km z Emilii do Rzgowa, kierowcy napotkają 7 fotoradarów i aż 64 potencjalne punkty zatrzymania i postoju, takie jak skrzyżowania z sygnalizacja świetlną i przejścia dla pieszych, czyli według przepisów ruchu drogowego miejsca bezwzględnego ustapienia pierwszeństwa. Zakładając, że kierowca samochodu ciężarowego przemieszczający się tą trasą będzie zmuszony zatrzymać się na każdym z tych punktów (natrafi na czerwone światło bądź pieszych na pasach), to przy średnim 
trwaniu cyklu zmiany świateł z czerwonego na zielone (ok. 1 min) przejazd zajmie 64 min, nie wliczając czasu spędzonego w kolejkach do tych świateł i samej jeździe. Natomiast w przypadku 36-kilometrowej trasy wschodniej takich punktów jest 46 i jedynie 2 fotoradary.

Podsumowujac obecny stan przebiegu tras tranzytowych przez aglomerację łódzką, można stwierdzić, że nie ma innego sposobu na rozwiązanie problemu kongestii, jak tylko poprowadzenie ciężkiego transportu samochodowego poza granicami miasta. Korzyści będą mogli czerpać wszyscy użytkownicy samochodów osobowych i ciężarowych. Miasta zostaną odciążone $z$ nadmiernego ruchu drogowego, spalin oraz hałasu. Mieszkańcy zyskają więcej przestrzeni drogowej, a podróżni - szybki i sprawny przejazd wokół aglomeracji, bez potrzeby włączania się w uciążliwy i bardzo nieekonomiczny ruch miejski.

Jednym z rozwiązań problemu zatłoczenia ww. skrzyżowań jest budowa estakad i poprowadzenie ruchu na wprost przez skrzyżowanie "góra". Przykładem takiego rozwiązania jest skrzyżowanie alei Włókniarzy z aleja Mickiewicza. Estakady mogłyby wpłynać na polepszenie warunków podróżowania przez aglomerację łódzką, gdyby pojawiły się w wyżej opisanych punktach newralgicznych oraz kilku innych, równie zatłoczonych, jak np. Rondo Solidarności. Niestety, nie ma pewności, czy zwiększenie przepustowości w tych - obecnie kryzysowych - punktach nie przeniosłoby kongestii w podobnym wymiarze na inne, obecnie mniej zatłoczone skrzyżowania.

Aby zilustrować rozmiar tranzytu i uogólnić skalę przejazdów przez aglomerację łódzką, liczbę przejeżdżających samochodów osobowych i pojazdów ciężarowych zestawiono w tab. 13.

Tabela 13. Natężenie ruchu w 2005 r.

\begin{tabular}{|l|c|}
\hline \multicolumn{1}{|c|}{ Trasa } & Liczba pojazdów na dobę (tys.) \\
\hline Trasa zachodnia, droga krajowa $\mathrm{nr} 1$ & 27,0 \\
\hline Trasa wschodnia, droga krajowa nr 14 & 17,5 \\
\hline Droga krajowa nr 71 (Zgierz-Pabianice) & 11,3 \\
\hline
\end{tabular}

Źródło: opracowanie własne na podstawie: Raport z konsultacji społecznych dla przedsięwzięcia p.n. budowa drogi ekspresowej S-14 - Zachodniej Obwodnicy Łodzi, Warszawa, grudzień 2008, za: http://s14.anim.pl/files/Raport_konsultacje_S14.pdf [z dn. 16.10.2012].

Szacuje się, iż w przeciągu 20 lat liczby te wzrosną odpowiednio nawet do 60 tys., 40 tys., 25 tys. pojazdów na dobę. 


\section{Podsumowanie}

W wyniku analiz przeprowadzonych w niniejszym rozdziale można sformułować następujące wnioski:

- Aglomeracja łódzka jest trzecim pod względem liczby mieszkańców systemem miejskim w Polsce. Znajduje się w centrum państwa na skrzyżowaniu dwóch głównych dróg krajowych, a zarazem dwóch bardzo ważnych transeuropejskich korytarzy transportowych.

- Drogi S8, S14, A1 i A2 wraz z węzłami nie tylko spełnią rolę obwodnic, przesuną ciężki tranzyt kołowy poza granice miasta, ale także dadzą możliwość przemieszczania się z jednego końca miasta na drugi z prędkościami autostradowymi, bez korków, postojów na światłach i przejściach dla pieszych. 



\title{
5. Pierścień dróg wokół aglomeracji łódzkiej
}

\author{
Damian Michalski*
}

\subsection{Plany rozbudowy dróg ekspresowych i autostrad w Polsce}

Każdy zmotoryzowany obywatel naszego kraju, a zapewne i wszyscy nasi sąsiedzi zmuszeni do podróżowania przez nasze państwo, z każdą zmiana rządu RP liczą na spełnienie odwiecznych obietnic wybudowania nowoczesnej oraz trwałej sieci dróg autostradowych i ekspresowych na terenie Polski. Nadzieje na urzeczywistnienie się tego wielkiego „polskiego snu" wzbudziło przyznanie Polsce organizacji Mistrzostw Europy w piłce nożnej w partnerstwie z Ukrainą w 2012 r.

Pierwsze drogi o autostradowych parametrach zbliżonych do dzisiejszych autostrad były budowane w okresie międzywojennym we Włoszech, następnie w Niemczech i Holandii ${ }^{1}$. Do dzisiejszego dnia kraje te przoduja w Europie. Niemcy posiadaja najdłuższe autostrady - 11427 km, zaś Holendrzy, z wynikiem 57,5 km/1000 km², nie maja sobie równych $w$ gęstości sieci autostrad². Dla porównania, gęstość polskiej sieci autostradowej wynosi 2,59 km/1000 km².

"Plany budowy autostrad w Polsce istnieja już od kilkudziesięciu lat. Po wojnie Polska odziedziczyła prawie $140 \mathrm{~km}$ poniemieckich autostrad"3. Pierwszy plan krajowej sieci dróg autostradowych zaprezentował prof. Nesterowicz w 1938 r. podczas IV Kongresu Drogowców w Warszawie. Projekt był przewidziany na 4695 km autostrad i miał być zrealizowany w ciaggu 50 lat. Niestety, rozpoczęciu inwestycji przeszkodził wybuch II wojny światowej, a po jej zakończeniu nie istniały już

* Mgr Damian Michalski - Katedra Logistyki, Wydział Zarządzania Uniwersytetu Łódzkiego, ul. Matejki 22/26, 90-237 Łódź.

${ }^{1}$ S. Koziarski, Transport w Europie, Wyd. Instytut Śląski, Opole 2005, s. 28.

2 Z. Roman, Międzynarodowe przewozy transportowe, Wyższa Szkoła Cła i Logistyki, Warszawa 2006, s. 54.

${ }^{3}$ T. Chrzan, Autostrady i materiały do ich budowy, Oficyna Wyd. Politechniki Wrocławskiej, Wrocław 2000, s. 18. 
dane, na podstawie których stworzono projekt. Zmienił się także kształt terytorium Polski ${ }^{4}$.

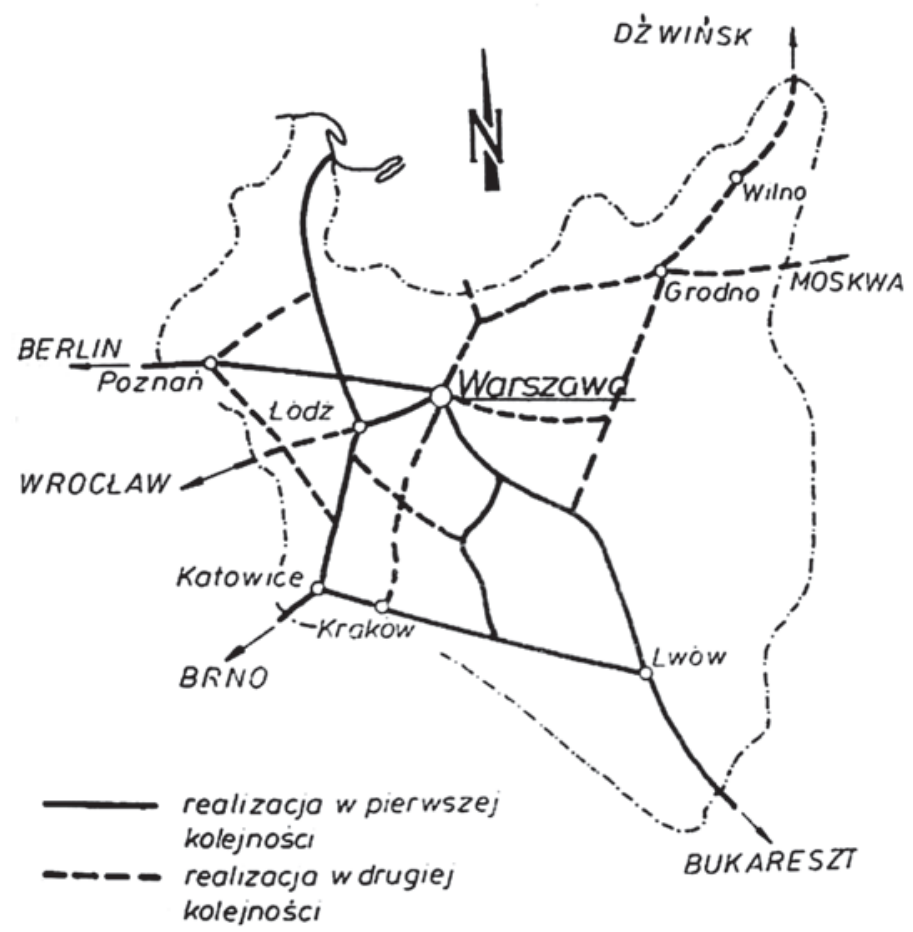

Rysunek 11. Sieć projektowanych autostrad w Polsce w 1938 r.

Źródło: R. Krystek, Węzły drogowe i autostradowe, Wyd. Komunikacji i Łączności, Warszawa 2008, s. 19

Od 1946 r. koncepcji budowy sieci szybkich dróg dla naszego kraju było wiele. Niestety, pozostały one w sferze planów. Dopiero w roku 1985 przyjęto koncepcję budowy 1900 km autostrad i 5100 km dróg ekspresowych. Realizację tego projektu przerwały zachodzące zmiany polityczne, gospodarcze i społeczne.

Obecnie w Polsce konsekwentnie jest realizowany plan z końca lat 90. XX wieku. Na przełomie tego dwudziestolecia był wielokrotnie modyfikowany. Zmiany dotyczą głównie terminów ukończenia odcinków oraz zastapienia planu budowy autostrady A3 planami budowy drogi ekspresowej S3 i A8 - droga S85.

${ }^{4}$ R. Krystek, Węzły drogowe i autostradowe, Wyd. Komunikacji i Łączności, Warszawa 2008 , s. 19.

${ }^{5}$ http://pl.wikipedia.org/wiki/Autostrady_w_Polsce [z dn. 2.11.2011]. 


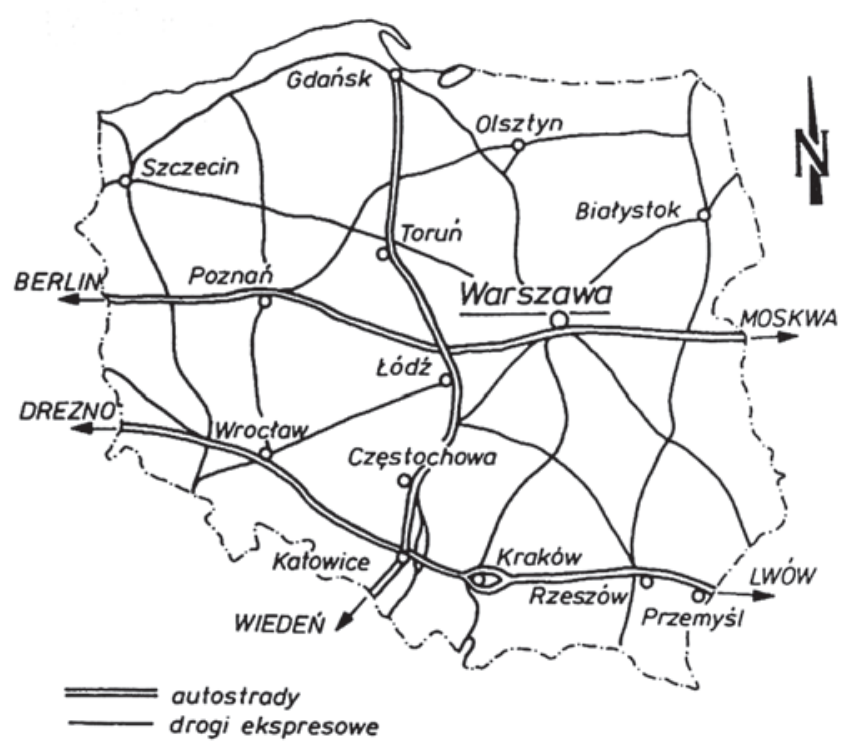

Rysunek 12. Plany na rok 1985

Źródło: jak do rys. 11, s. 30

Na chwilę obecną naszym kraju jest 1319 km dróg szybkiego ruchu, w tym 837 km autostrad oraz 482 km dróg ekspresowych. W budowie i przebudowie jest 777 km dróg krajowych. Trwaja prace przy budowie 317 km autostrad, 265 km dróg ekspresowych i 109 km obwodnic. W ramach Programu Budowy Dróg Krajowych na lata 2008-2012 obecnie realizowana jest także przebudowa $86 \mathrm{~km}$ istniejącej sieci'.

Priorytetami, które Polska jako organizator zobowiązała się zrealizować, są następujące drogi:

- autostrada A1 z Gdańska przez Grudziądz, Toruń, Łódź, Katowice, aż do przejścia granicznego w Gorzyczkach - ma mieć długość $582 \mathrm{~km}$. Trasa A1 jest fragmentem międzynarodowego ciągu komunikacyjnego E75, tworzącego VI transeuropejski korytarz transportowy. Do 2012 r. miała być gotowa cała autostrada, poza odcinkiem między Częstochową a Pyrzowicami, który będzie oddany do 2014 r., - autostrada A2 od granicy niemieckiej w Świecku przez Poznań, Łódź, Warszawę, aż do przejścia granicznego z Białorusią w Kukurykach - ma mieć długość $610 \mathrm{~km}$. Trasa A2 jest fragmentem międzynarodowego ciągu komunikacyjnego E30, tworzącego II transeuropejski

${ }^{6}$ Generalna Dyrekcja Dróg Krajowych i Autostrad podsumowuje 2009 rok, za: www.gddkia.gov.pl/article/informacje/archiwum_2009 [z dn. 30.03.2010]. 
korytarz transportowy. Do 2012 r. miała być gotowa autostrada na odcinku Świecko-Warszawa,

- autostrada A4, obecnie najdłuższy odcinek autostradowy w Polsce, rozpoczynający swój bieg na przejściach granicznych z Niemcami w Jędrzychowicach i Zgorzelcu, biegnący przez Wrocław, Katowice, Kraków, Rzeszów, aż do granicy z Ukrainą w Korczowie. Długość tej autostrady to $670 \mathrm{~km}$. Trasa A4 jest fragmentem międzynarodowego ciągu komunikacyjnego E40, tworzącego III transeuropejski korytarz transportowy. Do 2012 r. miała być gotowa cała autostrada od granicy z Niemcami aż do granicy ukraińskiej.

Tabela 14. Drogi ekspresowe o statusie "Priorytet na Euro 2012"

\begin{tabular}{|c|l|c|}
\hline $\begin{array}{c}\text { Nr drogi } \\
\text { ekspresowej }\end{array}$ & \multicolumn{1}{|c|}{ Przebieg } & $\begin{array}{c}\text { Długość } \\
(\mathrm{km})\end{array}$ \\
\hline 3 & $\begin{array}{l}\text { Międzyzdroje-Szczecin-Gorzów Wlkp.-Zielona } \\
\text { Góra-Legnica-Lubawka }\end{array}$ & 470 \\
\hline 5 & $\begin{array}{l}\text { Grudziądz-Świecie-Bydgoszcz-Gniezno-Poznań-Leszno- } \\
\text { Wrocław }\end{array}$ & 400 \\
\hline 7 & Elbląg-Olsztyn-Warszawa-Kielce-Kraków-Rabka & 720 \\
\hline 8 & $\begin{array}{l}\text { Wrocław-Łódź-Piotrków Tryb.-Rawa Mazowiecka-Warszawa- } \\
\text { Białystok-Budzisko }\end{array}$ & 680 \\
\hline 12 & Piotrków Trybunalski-Radom-Lublin-Dorohust & 315 \\
\hline 19 & Barwinek-Rzeszów-Lublin-Białystok-Białostocka & 570 \\
\hline
\end{tabular}

Źródło: opracowanie własne.

\subsection{System obwodnic wokół aglomeracji łódzkiej}

Zgodnie z zapowiedziami i planami Generalnej Dyrekcji Dróg Krajowych i Autostrad, wokół aglomeracji łódzkiej do 2014 r. ma powstać największy system dróg autostradowych i ekspresowych w kraju. Każda z dróg będzie jednocześnie spełniała rolę obwodnicy miasta, co może prowadzić do całkowitego wyeliminowania tranzytu przepływowego z obszaru miast aglomeracji. Cały system pozwoli na przejazd poziomy i pionowy oraz przemieszczanie się z jednego skrajnego punktu aglomeracji do drugiego poprzez jej objeżdżanie opisywanym systemem. Umożliwi to również dużo sprawniejsze poruszanie się po arteriach miejskich, z których w znacznym stopniu zniknie ciężki transport kołowy.

\footnotetext{
${ }^{7}$ www.droginaeuro.pl/strona/priorytety-euro-2012 [z dn. 30.03.2010].
} 
Na system składać się będą dwie autostrady: A1 i A2 oraz dwie drogi ekspresowe: S8 i S14. Wszystkie drogi stworzą na obszarze aglomeracji kwadrat dróg szybkiego ruchu, otaczając główne miasta aglomeracji - Łódź, Zgierz i Pabianice, zapewniając dostępność do owych dróg innym miastom. Cała idea ma już swoją potoczną nazwę „ringu łódzkiego". Ta nieformalna nazwa wskazuje, że system ten będzie spełniał rolę pierścieni autostradowych znanych z takich miast europejskich, jak Berlin czy Madryt. Każdy mieszkaniec aglomeracji, a także wszyscy podróżujacy przez ten obszar kraju z nadziejami patrza na obietnice urzędników związane z realizacją całego projektu.

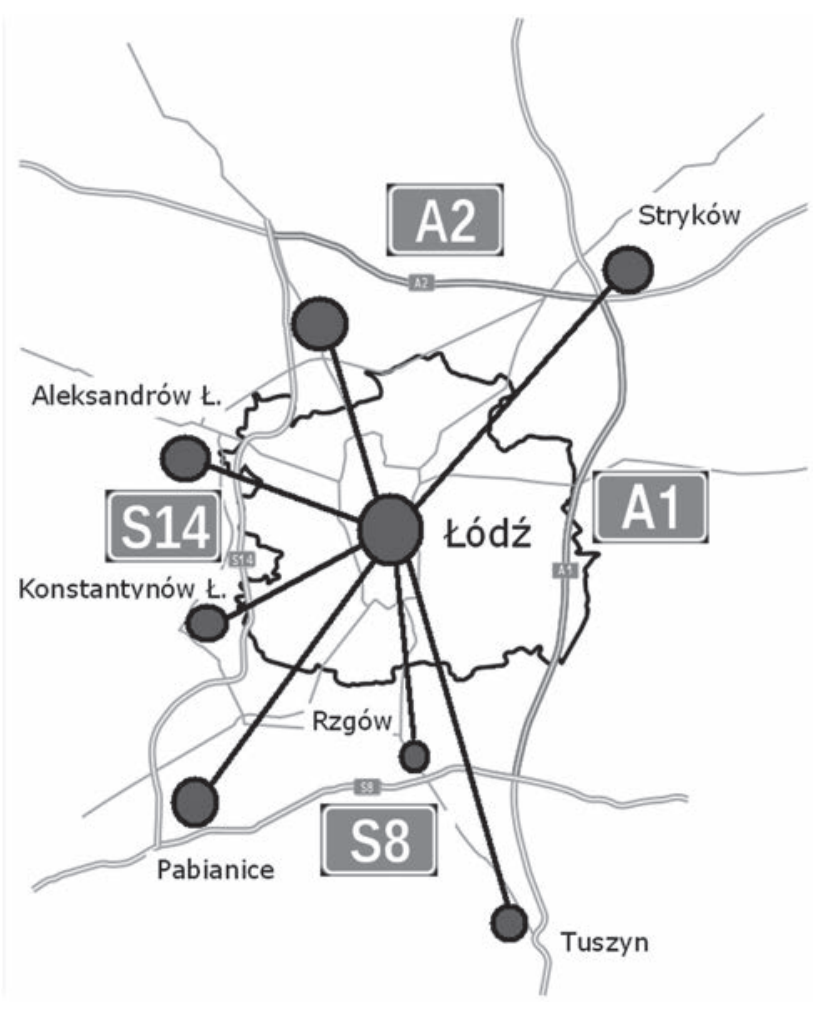

Rysunek 13. Autostradowy "pierścień łódzki"

Źródło: opracowanie - Anna Palczewska

Droga S8, według wariantu północnego, ma biec z Wrocławia przez Sieradz, Zduńską Wolę, Łask, Łódź, następnie zostaje przerwana, a ruch będzie kierowany autostrada $A 1$ na północ, aż do Piotrkowa, gdzie trasa S8 kontynuuje swój bieg na Warszawę. W celu pełnego 
osiągnięcia ciągłości trasy S8, planowana droga S74 musi przejąć rolę łącznika między obydwoma odcinkami $\mathrm{S}^{8}$. Odcinek trasy pomiędzy węzłem Róża a węzłem Wrocław, o długości ok. 20 km, stanowić będzie południową obwodnicę miasta Łodzi.

Droga ekspresowa S14 ma być zachodnią obwodnica Łodzi, zaś autostrada A1 na odcinku o długości ok. 30 km pomiędzy węzłem Stryków a węzłem Łódź-Południe będzie wschodnią obwodnicą Łodzi. Obecnie istnieje jeden element tego systemu - jest to północna obwodnica Łodzi, którą stanowi 19-kilometrowy odcinek autostrady A2 pomiędzy węzłem Emilia a węzłem Stryków.

Tabela 15. Elementy systemu obwodnic wokół aglomeracji łódzkiej

\begin{tabular}{|c|c|l|}
\hline Obwodnica & Długość & \multicolumn{1}{|c|}{ Skąd/dokąd } \\
\hline S1 & $30,2 \mathrm{~km}$ & węzeł Stryków/węzeł Łódź-Południe \\
\hline $\mathbf{S 1 4}$ & $18,8 \mathrm{~km}$ & węzeł Emilia/węzeł Łódź-Północ \\
\hline $\mathbf{S 1 4}$ & $21,7 \mathrm{~km}$ & węzeł Róża/węzeł Łódź-Południe \\
\hline
\end{tabular}

Źródło: opracowanie własne na podstawie materiałów otrzymanych z GDDKiA Oddział Łódź z dn. 2.11.2011.

Trasa S8 jako południowa obwodnica Łodzi swój bieg zacznie na węźle Róża ok. 10 km na południowy zachód od Pabianic. Jako element systemu obwodnic, zapewni dostępność komunikacyjną lokalnym społecznościom poprzez węzły w Pabianicach i Rzgowie, aby ostatecznie zakończyć swój bieg na autostradzie A1 w węźle Łódź-Południe. Długość całego odcinka wynosi $21,7 \mathrm{~km}$ i - jak cała trasa S8 - ma posiadać dwie jezdnie po dwa pasy ruchu w każdym kierunku, oddzielone aż 10-metrowym pasem zieleni, w razie konieczności poszerzenia w przyszłości każdej z jezdni o jeden pas .

${ }^{8}$ R. Kozłowski, I. Tomczyk, Problematyka budowy dróg w Polsce na przykładzie drogi ekspresowej S-8 w województwie łódzkim, 2K s.C., Łódź-Sieradz 2009, s. 91.

${ }^{9}$ A. Wojtala, Koniec walki o S-8, "Tydzień Trybunalski”, 22.02.2007, za: http://fakty. interia.pl/newsroom/news/koniec-walki-o-s-8,919295 [z dn. 31.05.2007]. 
Zachodnia obwodnica miasta Łodzi, czyli trasa S14, zacznie się na węźle autostrady A2 w Emilii i zostanie skierowana w kierunku węzła Róża w celu połączenia $z$ trasą S8. Trasa będzie zapewniała wjazdy i zjazdy dla lokalnej społeczności oraz utrzymywała komunikację wokół aglomeracji w ramach systemu za pomocą następujących węzłów:

- Lućmierz,

- Aleksandrów Łódzki,

- Łódź-Teofilów,

- Konstantynów Łódzki,

- Łódź-Rekinia,

- Łódź-Północ,

- Pabianice-Północ,

- Dobroń.

Cała długość trasy ma wynosić 40,7 km z dopuszczalną prędkością $100 \mathrm{~km} / \mathrm{h}$.

Wschodnia obwodnica Łodzi, czyli fragment betonowej autostrady A1, swój bieg zacznie w węźle Łódź-Północ, w którym krzyżować się będzie $z$ autostradą $A 2$. Obwodnica będzie się kończyć na węźle Łódź-Południe, w miejscu połączenia z droga ekspresową S8, i będzie zapewniała wjazdy i zjazdy dla społeczności lokalnej oraz utrzymywała komunikację wokół aglomeracji w ramach systemu za pomocą następujacych węzłów:

- Brzeziny,

- Łódź-Wschód,

- Romanów.

Długość tego odcinka trasy to około $30,2 \mathrm{~km}$.

\subsection{Problemy z budową}

Za każdymi obietnicami muszą iść odpowiednie działania. Podobnie jest z budowa dróg szybkiego ruchu w Polsce. Schemat czynności w uproszczeniu wygląda zawsze tak samo. Najpierw sporządzany jest projekt inwestycji, zostaje ogłoszony przetarg na wykonawcę oraz wskazywane sa źródła finansowania budowy. Polskie realia administracyjne i liczne problemy związane z wyznaczaniem tras bez szkody dla aktualnego zagospodarowania przestrzennego oraz dla społeczności lokalnych, a przede wszystkim uzyskanie środków na sfinansowanie wartych miliardy złotych inwestycji - sprawiaja, że jest to proces bardzo trudny. Co więcej, jak pokazuja dotychczasowe wyniki w budowie autostrad, 
jest to również proces długotrwały. Dużą szansą było odbywające się w Polsce w 2012 r. Euro, co Łodzi, która przecież nie jest miastem gospodarzem, zapewniło znaczące infrastrukturalne korzyści, jakimi jest budowa tras A1, A2 i S8. Niestety, już dziś wiadomo, że ze wszystkimi zaplanowanymi projektami na czas mistrzostw Polska nie zdąży, ale do 2014 r. istnieją realne szanse, że zostaną wykonane.

Do czasu mistrzostw w 2012 r. miała być gotowa cała autostrada A2 ze Świecka aż do Warszawy, podobnie ma się sprawa z trasą $A 1$, choć na chwilę obecną na odcinek dalszej części trasy, aż do Katowic, wciąż nie ogłoszono przetargu. Opóźnienia są spowodowane wycofaniem się wraz z projektem hiszpańskiego wykonawcy inwestycji, która przewidywała ten odcinek jako autostradę koncesyjną. Istniała możliwość odkupienia projektu, by nie rozpoczynać pracy od punktu wyjścia, ale niestety projekt autostrady koncesyjnej po przejęciu inwestycji przez skarb państwa jest nie do przyjęcia, głównie za sprawą aktualnego programu budowy dróg "Projektuj i buduj".

Niełatwym zadaniem było usytuowanie trasy S14, której pierwszy etap budowy, czyli obwodnica Pabianic, już ruszył. Z początku zaproponowano trzy warianty przebiegu trasy, które spotkały się z dezaprobatą mieszkańców terenów sąsiadujących z planowaną trasa. Sprzeciwiano się wyburzeniu nowo pobudowanych domów jednorodzinnych, np. na osiedlu Smulsko, i przecięciu go na dwie odseparowane części czy poprowadzeniu trasy w obrębie jednego z większych łódzkich osiedli - Retkinia. Ostatecznie do dalszego projektowania wybrano wersję określana w planach jako wariant czerwony. Niestety, nie jest on wolny od wad, tj. przebiega blisko zgierskiego osiedla mieszkaniowego, przecina ulice Zimna Woda i Mikołajew, gdzie powstały nowe domy jednorodzinne ${ }^{10}$.

Łódź mogła w ogóle nie mieć dostępu do trasy S8. Z początku trasa została zaprezentowana w wariancie południowym, czyli krótszym, wiodącym przez Wieluń, Bełchatów i Piotrków Trybunalski. Natomiast akcje protestacyjne mieszkańców Łodzi, Pabianic, Sieradza, Łasku, Zduńskiej Woli i działania samorządowców sprawiły, iż ostatecznie wybrano wariant północny, znacznie bardziej korzystny dla Łodzi, choć zaburzający ciągłość trasy.

Podobne utrudnienia spotykaja trasę S8 ze strony niezadowolonych mieszkańców, chociażby okolic Rzgowa. Niestety, nie przekonuje ich fakt, że w przypadku przeprowadzenia trasy inaczej, niż zaprojektowano,

${ }_{10}$ M. Bereszczyński, Przebieg drogi S14 jest już praktycznie przesądzony, za: http://lodz.naszemiasto.pl/wydarzenia/910324.html [z dn. 16.10.2008]. 
Rzgów straci szansę na węzeł drogowy, czyli wjazdy i zjazdy do tej trasy. Mieszkańcy Rzgowa, aby skorzystać z drogi S8, musieliby udać się do węzła w pobliskim Tuszynie i następnie autostradą A1 wrócić do węzła Łódź-Południe, gdzie znajdowałby się wjazd na S8.

Nie sa to odosobnione przypadki. Niemalże niemożliwe jest poprowadzenie trasy w taki sposób, aby uniknąć konieczności wysiedleń mieszkańców. Można jedynie starać się zminimalizować to zjawisko, co wiąże się z ponoszeniem wysokich kosztów (nowe projekty, plany zagospodarowania przestrzennego) oraz przedłużaniem czasu trwania inwestycji, choć urzędnicy GDDKiA Oddział Łódź zapewniaja, że taki obrót sytuacji - opóźnienia i przestoje w pracy - na pewno nie są skutkiem braku środków finansowych na dane inwestycje.

\section{Podsumowanie}

W wyniku analiz przeprowadzonych w niniejszym rozdziale sformułowano następujące wnioski:

- Istnieja plany rozbudowy sieci autostrad i dróg ekspresowych naszego kraju, które są realizowane. Fragmenty tej sieci stworzą tak bardzo potrzebny aglomeracji łódzkiej system obwodnic. Dzięki niemu miasto "odetchnie" od ciężaru spalin i hałasu TIR-ów. „Pierścień łódzki" zgodnie z obietnicami samorządowców, ma powstać do 2015 r., a Łódź stanie się jedynym polskim miastem otoczonym z każdej strony drogą szybkiego ruchu.

- Wszelkim inwestycjom, takim jak budowa tras szybkiego ruchu o ściśle określonych parametrach, towarzyszą utrudnienia związane $z$ aktualnym stanem zagospodarowania przestrzennego, dofinansowaniem czy protestami mieszkańców wysiedlanych z terenów przeznaczonych pod budowę autostrad. 



\section{Wpływ infrastruktury transportowej na funkcjonowanie C.H. Port kódź i miasta kodzi}

Joanna Zasada*

\subsection{Charakterystyka inwestycji C.H. Port Łódź}

Niniejszy rozdział przedstawia stan zaawansowania budowy analizowanej inwestycji na grudzień $2009 \mathrm{r}$.

Kilka ostatnich lat było dla Łodzi bardzo korzystnym okresem, jeśli weźmiemy pod uwagę inwestycje zagraniczne, takie jak Indesit, Gillette czy Bosch \& Siemens. Największym udziałem zainwestowanego kapitału cieszą się przemysł oraz handel i usługi ${ }^{1}$, ale korzystne położenie geograficzne przyciaga także branżę logistyczną - w Łodzi zaczyna bowiem powstawać coraz więcej nowoczesnych magazynów. Inwestorzy decyduja się lokować pieniądze na tym obszarze z dwóch powodów: po pierwsze, Łódź oferuje jedne z najniższych cen za metr powierzchni użytkowej terenów inwestycyjnych (dane za 2008 r.) ${ }^{2}$, ponadto miasto dysponuje dużą liczbą zdolnych, wysoko wykwalifikowanych, a przy tym tanich pracowników. Za jedną z najbardziej spektakularnych inwestycji $\mathrm{w}$ regionie $\mathrm{w}$ czasie ostatnich kilkunastu miesięcy, uważa się projekt Port Łódź wraz z największym w Polsce sklepem IKEA.

5 listopada 2008 r. rozpoczęto budowę Portu Łódź - centrum handlowego, które swoja powierzchnia 127 tys. $\mathrm{m}^{2}$ przewyższa wszystkie dotychczasowe inwestycje, jak C.H. M1, C.H. Tulipan, C.H. Pasaż Łódzki, Galerię Łódzką czy nawet Manufakturę. Nowoczesny kompleks powstaje na skrzyżowaniu ulic Pabianickiej i Chocianowickiej. Na jego terenie będzie działało ponad 200 sklepów i punktów usługowych o zróżnicowanej ofercie $^{3}$, z których największym, zajmującym powierzchnię 33 tys. $\mathrm{m}^{2}$,

* Mgr Joanna Zasada - Katedra Logistyki, Wydział Zarządzania Uniwersytetu Łódzkiego, ul. Matejki 22/26, 90-237 Łódź.

${ }^{1}$ www.invest.lodz.pl/index.php?str=2551 [z dn. 11.01.2010].

2 www.serwisinwestora.pl/nieruchomosci/ceny_gruntow_inwestycyjnych_poznaj_wyniki_raportu_o_rynku_nieruchomosci_colliers_international-179.html [z dn. 11.01.2010].

${ }^{3}$ www.portlodz.pl/media/informacjeprasowe.html [z dn. 30.11.2009]. 
jest sklep IKEA. Zatrudnienie znajdzie tu łącznie 2 tys. osób. Według informacji prasowej podanej na oficjalnej stronie Portu, całkowity koszt inwestycji szacowany jest na około 200 mln euro.

Zgodnie z założeniami architektów, powstające na planie trójkąta centrum handlowe zaaranżowane zostanie w konwencji odwołujacej się do trzech stref przyrody: górskiej, wodnej i leśnej. Do każdej z nich starannie wyselekcjonowano materiały oraz elementy wykończenia ${ }^{4}$. Aż 7 tys. $m^{2}$ zajmie Patio - nowatorskie przedsięwzięcie o charakterze sportowo-rekreacyjno-relaksacyjnym.

Tym, co niewątpliwie wyróżnia Port Łódź wśród innych centrów handlowych, jest bardzo dobre rozwiązanie komunikacyjne - inwestor musiał postarać się, aby do zlokalizowanego na obrzeżach miasta kompleksu przyciągnąć jak największą liczbę potencjalnych klientów. $W$ tym celu na terenie centrum powstały dwa zupełnie nowe przystanki szybkiej linii tramwajowej, zmodernizowano drogi biegnące wzdłuż Portu oraz zadbano o połaczenie z planowana obwodnica miasta - droga ekspresową S14. Dla klientów dojeżdżających własnym samochodem przygotowano 4500 miejsc parkingowych.

Przewidywany dla Portu Łódź zasięg sprzedaży to 1,8 mln osób. Został on podzielony na trzy strefy, według czasu potrzebnego na dojazd samochodem. Sa to odpowiednio:

- strefa I: < 20 min - należą do niej głównie miasta Łódź i Pabianice,

- strefa II: 20-40 min - obejmuje miasta, takie jak Zgierz, Aleksandrów Łódzki, Konstantynów Łódzki, Łask, Bełchatów, Piotrków Trybunalski, - strefa III: 40-60 min - do niej zaliczyć można Łęczycę, Ozorków, Poddębice, Sieradz, Zduńską Wolę, Tomaszów Mazowiecki, Głowno.

Inwestorem projektu jest Inter IKEA Centre Group A/S (IICG), będąca własnością IKEA Group oraz Inter IKEA Group. Ze swojej siedziby głównej w Kopenhadze, IICG zarządza parkami handlowymi w kilku krajach europejskich oraz Chinach, o łącznej powierzchni ponad 800 tys. $\mathrm{m}^{2}$. W ciaggu kilku najbliższych lat planowane jest jej podwojenie poprzez ekspansję na pozostałe kraje Europy ${ }^{5}$. Celem IICG jest tworzenie miejsc atrakcyjnie zlokalizowanych i dobrze zorganizowanych - przyciagających wielu klientów wraz z całymi rodzinami oraz satysfakcjonujących partnerów biznesowych grupy ${ }^{6}$. Najważniejszym z nich jest zawsze IKEA.

\footnotetext{
${ }^{4}$ www.portlodz.pl/portx141dx17a/koncept.html [z dn. 30.11.2009].

${ }^{5}$ www.iicg.pl/About\%20Us/History.aspx [z dn. 01.11.2011].

${ }^{6}$ www.iicg.pl/About\%20Us/Mission.aspx [z dn. 01.11.2011].
} 


\subsection{Zmiany $w$ infrastrukturze transportowej na obszarze otaczającym C.H. Port Łódź w ostatnich latach}

Modernizacja infrastruktury drogowej na terenie bezpośrednio sasiadującym z planowaną inwestycją dotyczyła około 1,5-kilometrowego odcinka ulicy Pabianickiej - od rzeki Ner do granic miasta Łodzi z Ksawerowem. Dotychczas była to droga dwupasmowa, posiadająca po jednym pasie ruchu w każda stronę, a stan techniczny jezdni określono jako zły․ Na podstawie dokumentu zawierającego specyfikację istotnych warunków zamówienia dotyczącego rozbudowy wspomnianego wcześniej odcinka drogi wiadomo, iż zakres rzeczowy zamówienia obejmował:

- roboty drogowe,

- roboty torowe,

- kanalizację deszczowa,

- odwodnienie,

- oświetlenie,

- budowę drenażu torowiska tramwajowego,

- przebudowę mostu drogowego,

- budowę muru oporowego,

- budowę ekranów akustycznych,

- budowę ekspedycji przy pętli tramwajowej,

- wymianę okien,

- wycinkę drzew,

- urządzenie zieleni.

Do materiałów wejściowych, na których opierały się wszystkie projekty i pomysły nowego rozwiązania drogi biegnącej przy centrum handlowym, należały m.in. ${ }^{9}$ :

- koncepcja programowo-przestrzenna obwodnicy miasta Pabianice w rezerwowanym korytarzu drogi krajowej nr 14 bis i S14 na odcinku Ksawerów-Dobroń (ok. 16 km), opracowanie Mosty Katowice Sp. z o.o. na zlecenie GDDKiA Oddział w Łodzi,

7 Projekt budowlano-wykonawczy zagospodarowania terenu (dokumentacja przetargowa), luty 2008, za: www.zdit.uml.lodz.pl/index.php?str=65 [z dn. 01.08.2009].

8 Zarząd Dróg i Transportu w Łodzi, Specyfikacja istotnych warunków zamówienia, nr sprawy NrZDiT.NZ.3320-90/08 [z dn. 12.08.2009].

9 Projekt architektoniczno-budowlany $i$ wykonawczy dróg wraz z torami tramwajowymi, za: www.zdit.uml.lodz.pl/index.php?str=65 [z dn. 01.08.2009]. 
- miejscowy plan zagospodarowania przestrzennego dla części obszaru miasta Łodzi położonej w rejonie ulic Chocianowickiej i Pabianickiej,

- koncepcja przebudowy ulicy Pabianickiej na odcinku od rzeki Ner do granic miasta - opracowanie mgr inż. J. Jasiński na zlecenie Pracowni Projektowej Lipski-Wujek dla IKEA,

- protokół z dnia 20 września 2006 r. z Rady Technicznej w sprawie zatwierdzenia rozwiązań geometrycznych z torami włącznie dla ulicy Pabianickiej na odcinku od rejonu mostu na rzece Ner do północnej granicy miasta,

- pomiary sytuacyjno-wysokościowe,

- porozumienie zawarte między Inter IKEA Centre Polska S.A. a Urzędem Miasta Łodzi.

Z Projektu architektoniczno-budowlanego i wykonawczego dróg wraz z torami tramwajowymi, opracowanego przez Juliusza Jasińskiego dla Inter IKEA Centre Polska S.A. oraz Zarządu Dróg i Transportu w Łodzi, uzyskujemy informację o szczegółowych parametrach projektowych przebudowy drogi. I tak, na odcinku od rzeki Ner do węzła (gdzie w przyszłości będzie przebiegać trasa S14), biegnie droga klasy $\mathrm{G} 2 / 3+\mathrm{T}^{10}$, o prędkości projektowej ${ }^{11} 60 \mathrm{~km} / \mathrm{h}$ (w rejonie ronda $40 \mathrm{~km} / \mathrm{h}$ ), dopuszczonej ${ }^{12}-50 / 60 \mathrm{~km} / \mathrm{h}$. Jej szerokość jest nieregularna, wynosi od 47 m w części Ner-Chocianowicka, do 60-70 m w części Chocianowicka-węzeł (przy czym szerokość każdego pasa jezdni to 3,5 m). Po stronie zachodniej aż do pętli położono chodnik o szerokości $3 \mathrm{~m}$ z dwukierunkową ścieżką rowerową o szerokości 2,5 m, kończącą się na wysokości zjazdu do IKEI. Strona wschodnia posiada chodnik o szerokości 2,25 m, bez ścieżki rowerowej. Istniejące na tym odcinku dwa skrzyżowania: z ulicami Chocianowicką-Ciechocińską oraz z wjazdem na teren Centrum IKEA (skrzyżowanie typu T), skanalizowano i wyposażono w sygnalizację świetlna, która planowo przystosowana zostanie jako akomodacyjna.

${ }^{10}$ Litera G w oznaczeniu technicznym dróg oznacza, że jest to droga główna; oznaczenie 2/3 - dwa pasy trzypasmowe; oznaczenie $+\mathrm{T}$ - plus torowisko tramwajowe.

${ }^{11}$ Prędkość projektowa - rozumie się przez to parametr techniczno-ekonomiczny, któremu są przyporządkowane graniczne wartości elementów drogi, proporcje między nimi oraz zakres wyposażenia drogi; prędkość projektowa nie jest związana z prędkością dopuszczalna, o której mowa w przepisach o ruchu drogowym, za: Rozporządzenie Ministra Transportu i Gospodarki Morskiej z dnia 2 marca 1999 r. w sprawie warunków technicznych, jakim powinny odpowiadać drogi publiczne i ich usytuowanie, Dz.U. z 1999 r., nr 43, poz. 430 (dział I, § 3, pkt 5).

12 Prędkość dopuszczona przez przepisy drogowe. 
Od węzła do granic miasta parametry drogi wyglądaja nieco inaczej: jej klasa to $\mathrm{Z1} / 2+\mathrm{T}^{13}$, prędkość projektowa $40 \mathrm{~km} / \mathrm{h}$, dopuszczona - 50/60 km/h, szerokość ok. $50 \mathrm{~m}$, zwężająca się do ok. $30 \mathrm{~m}$ na granicy z Ksawerowem. Po stronie wschodniej biegnie również przyległy do jezdni, dwumetrowy chodnik z połączeniem do rejonu pętli tramwajowej.

Z punktu widzenia podróżujących tą trasą kierowców, efekt robót drogowych przedstawia się następująco: mają oni do dyspozycji od dwóch do pięciu pasów ruchu - skrajne do skrętów w prawo i w lewo oraz trzy do jazdy na wprost. W ramach prac drogowych wybudowano dwie nowe jezdnie: zachodnią, prowadząca od centrum Łodzi w stronę granicy miasta, o długości $1360 \mathrm{~m}$ i szerokości od dwóch pasów ruchu (przy zjeździe z estakady) do pięciu w rejonie wjazdu do Portu Łódź, oraz wschodnia, licząca 1452 m długości i szerokość od dwóch do czterech pasów ruchu (na odcinku od ulicy Chocianowickiej do ulicy Mierzejowej) ${ }^{14}$.

Przy jednym ze zjazdów do budowanego centrum handlowego powstało rondo o wymiarach:

- średnica wewnętrzna - $80 \mathrm{~m}$,

- średnica zewnętrzna - $95 \mathrm{~m}$,

- szerokość - 7,5 m,

- długość jezdni na rondzie - $251 \mathrm{~m}$.

Ten fragment nowej infrastruktury jest bardzo istotny, gdyż w przyszłości ma zostać połączony estakadą z drogą S14 - planowaną zachodnią obwodnica miasta.

Planowana trasa S14 ma połączyć (biegnąc południkowo wzdłuż zachodnich granic miast: Zgierz, Łódź, Pabianice) autostradę A2 z droga ekspresową S8. Jej łączna długość wyniesie ok. 42 km, z czego obwodnica miasta Łodzi ok. $30 \mathrm{~km}$.

Historia S14 sięga roku 2005, w którym zawarte zostało, pod patronatem premiera rządu RP, Porozumienie $w$ sprawie określenia wspótpracy służącej przygotowaniu do realizacji Zachodniej Obwodnicy Łodzi w ciągu drogi ekspresowej S-14 wraz z obwodnicą Pabianic pomiędzy GDDKiA, Łódzkim Urzędem Wojewódzkim oraz Gmina Łódź - określające także realizację związanej $z$ tą obwodnicą drogi $S 8^{15}$. Porozumienie

${ }^{13}$ Litera Z w oznaczeniu technicznym dróg oznacza, że jest to tzw. droga zbiorcza; oznaczenie $1 / 2$ - jeden pas dwupasmowy; oznaczenie $+T$ - plus torowisko tramwajowe.

${ }^{14}$ Otwarcie zmodernizowanego odcinka ulicy Pabianickiej, za: www.portlodz.pl/media/informacjeprasowe.html [z dn. 06.01.2010].

${ }^{15}$ www.uni-logistics.pl/historia_s8.html [z dn. 8.11.2011]. 
to charakteryzuje układ drogowy, podział zadań dla stron biorących w nim udział oraz wstępny harmonogram planowanych prac. Zachodnia Obwodnica Łodzi obejmuje, zgodnie z porozumieniem, następujące odcinki realizacyjne ${ }^{16}$ :

- południowy odcinek I (obwodnica Pabianic),

- północny odcinek II: od drogi krajowej nr 1 do węzła Łódź-Teofilów w ciągu drogi ekspresowej S14, wraz z łącznikami drogi nr 72: do ulicy Szczecińskiej i do drogi krajowej nr 71,

- środkowy odcinek III: od węzła z obwodnica Pabianic do ulicy Maratońskiej w Łodzi w ciągu drogi ekspresowej S14,

- środkowy odcinek IV: od węzła Łódź-Teofilów na S14 do węzła w Łodzi z ulica Maratońską w ciągu drogi ekspresowej S14.

Po tzw. konsultacjach społecznych, jakie odbywały się kilkakrotnie parę miesięcy później, okazało się jednak, że do każdego z wariantów zgłoszono liczne uwagi, a jeden z nich (tzw. wariant niebieski) został wręcz oprotestowany przez mieszkańców wybudowanego niedawno osiedla, w miejscu którego wytyczono przebieg fragmentu drogi. Radni miejscy w trakcie licznych debat i dyskusji najczęściej opowiadali się jednak za tzw. wariantem czerwonym, jako najmniej szkodliwym dla terenów, przez które przebiega. Pozwoliłby on odsunąc ruch transportowy z centrum miasta, natomiast przyjałby ruch regionalny, dzielnicowy. Z Kalendarza budowy drogi ekspresowej S-14, zamieszczonego na stronie http://lodz.naszemiasto.pl/wydarzenia/910324.html wynika, iż prace nad tą inwestycją maja się rozpocząć w roku 2011, a zakończyć w przeciągu 2-3 lat. O płynących z niej korzyściach dla miasta zostanie wspomniane poniżej.

Modernizacja na opisywanym wcześniej odcinku ulicy Pabianickiej objęto także sieć trakcyjną. Uwzględniała ona rozbudowę zajezdni Chocianowice, wymagająca poszerzenia rozstawu torów czy zwiększenia promieni łuków torów dla ułatwienia wjazdów i wyjazdów tramwaju z zajezdni. Z projektu budowlanego trakcji tramwajowej MPK (autor L. Adamczyk) ze stycznia 2007 r. wynika, że w sieci trakcyjnej zastosowano zwrotnice podgrzewane, sterowane elektrycznie, spełniające określone warunki bezpieczeństwa: „Układ musi pozwalać na bezpieczne prowadzenie ruchu tramwajowego przez projektowane rozjazdy torowe, wykluczając możliwość przypadkowego przestawienia zwrotnicy w chwili, gdy w strefie zwrotnicy znajduje się wagon tramwajowy. [...]

${ }^{16}$ Raport z konsultacji społecznych dla przedsięwzięcia p.n. budowa drogi ekspresowej S-14 - Zachodniej Obwodnicy Łodzi, Warszawa, grudzień 2008, za: www.gddkia.gov.pl/ article/oddzialy/gddkia_lodz/informacje [z dn. 06.02.2010]. 
Do sterowania podgrzewania zwrotnic należy zastosować sterownik mikroprocesorowy. Sterownik musi pozwalać na inteligentne sterowanie ogrzewaniem rozjazdu lub grupy rozjazdów w oparciu o dokonywany pomiar temperatury szyny".

Przystanki zlokalizowano w rejonach bardzo dogodnych dla osób podróżujących do centrum handlowego miejskimi środkami transportu. Przystanki autobusowe znajduja się przy skrzyżowaniu ulic Pabianickiej i Chocianowickiej. W rejonie pętli uwzględniono także przesiadkowe przystanki autobusowe na wypadek awarii komunikacji tramwajowej, z wybudowaną specjalnie jezdnią dla autobusów, połączoną z jezdnią zachodnia ulicy Pabianickiej ${ }^{17}$.

Remont ulicy Pabianickiej uwzględniał ponadto jej odwodnienie na całym opisywanym odcinku. Zaprojektowane odwodnienie obejmowało: w obrębie jezdni nowe oraz istniejące wpusty deszczowe, przy czym te istniejace musiano dostosować wysokościowo do nowo budowanej nawierzchni, w obrębie torowiska natomiast - wpusty deszczowe, skrzynki odwadniające, zbiorcze studzienki drenażowe. Jako odbiorniki wód powierzchniowych przewidziano projektowane oraz istniejące kanały deszczowe o średnicach $1,4-0,4 \mathrm{~m}$ i 0,5 $\mathrm{m}^{18}$.

Aby zminimalizować tzw. negatywne oddziaływanie akustyczne drogi, w wybranych miejscach wzdłuż ulicy Pabianickiej zlokalizowano ekrany akustyczne, chroniące przed nadmiernym hałasem. „Łączna ich długość wynosi około $860 \mathrm{~m}$, a wysokość od 3 do $4 \mathrm{~m}$. W ekranach przezroczystych odbijających zastosowano płyty poliwęglanowe grubości $12 \mathrm{~mm}$ w systemowych ramach aluminiowych, montowanych na czterech krawędziach płyt. Dla ekranu przezroczystego odbijającego z właściwościami pochłaniającymi przyjęto rozwiązanie z płyt poliwęglanowych $12 \mathrm{~mm}$, połączonych z pionowymi elementami pochłaniajacymi wykonanymi z blachy aluminiowej perforowanej z wypełnieniem wełną mineralna"19.

Wśród usprawnianych elementów infrastruktury na obszarze sąsiadującym z centrum handlowym znalazł się również most na rzece Ner. Z charakterystyki technicznej obiektu, zawartej w Opisie technicznym do projektu remontu mostu drogowego wiadomo, iż dotychczasowa szerokość

17 Projekt architektoniczno-budowlany i wykonawczy dróg wraz z torami tramwajowymi, za: www.zdit.uml.lodz.pl/index.php?str=65 [z dn. 01.08.2009].

${ }_{18}$ Opracowanie własne na podstawie dokumentacji przetargowej dotyczącej odwodnienia ul. Pabianickiej na odcinku od rzeki Ner do granicy miasta, styczeń 2008, za: www.zdit.uml.lodz.pl/index.php?str=65 [z dn. 01.08.2009].

19 Projekt budowlano-wykonawczy "Ekrany akustyczne", luty 2008, www.zdit.uml. lodz.pl/index.php?str $=65$ [z dn. 01.08.2009]. 
całkowita obiektu wynosiła 12,61 m, światło poziome pod mostem 1,0 m, długość ustroju niosącego 11,30 m, a długość ze skrzydełkami 17,32 m. Ostatnia modernizacja obiektu miała miejsce w 1998 r. Stan techniczny obiektu uznano za dość zadawalający, aby po remoncie jego nośność zachowywała klasę B (do 40 ton) według PN-85/S-10030.

Aby dostosować obiekt do zmienionej wysokości jezdni ulicy Pabianickiej, dokonano całkowitej rozbiórki nawierzchni na moście oraz na bezpośrednio sąsiadującym z nią fragmencie ulicy. Przebudowa obejmowała zatem wykonanie ${ }^{20}$ :

- płyty żelbetowej zdylatowanej (tj. rozszerzonej) podłużnie i poprzecznie na dotychczasowej (w planie) jezdni na moście o grubości 24-31 cm, z połączeniem z istniejąca płytą wzmacniająca oraz z konstrukcją istniejącego mostu,

- obustronnych kap - pasm przykrawężnikowych, połączonych z istniejącymi kapami wraz z krawężnikami oraz barierami,

- izolacji na nowej nadbudowanej płycie żelbetowej pomostu oraz na skutych częściach istniejących kap, po uprzednim wykonaniu warstwy wyrównującej kapy,

- zabezpieczenia antykorozyjnego całej spodniej strony ustroju niosącego.

\subsection{Efekty rozbudowy infrastruktury drogowej dla analizowanego centrum handlowego i dla miasta Łodzi}

Rezultaty, jakie dawać może tworzenie nowych czy rozbudowa istniejących odcinków infrastruktury transportu drogowego, wynikaja bezpośrednio z pełnionych przez nią funkcji:

- przede wszystkim infrastruktura ta umożliwia transfer w przestrzeni osób, ładunków, informacji,

- tym samym przyczynia się do powstania niezbędnych powiązań przestrzennych, więzi społeczno-ekonomicznych oraz informacyjnych - stanowi o spójności, zintegrowaniu danego regionu,

- poprzez funkcję lokalizacyjną infrastruktura świadczy o atrakcyjności (bądź jej braku) danego regionu (np. dla inwestorów).

${ }^{20}$ Opracowanie własne na podstawie opisu technicznego do projektu remontu mostu drogowego przez rzekę Ner w ciagu przebudowywanej ulicy Pabianickiej na odcinku od rzeki Ner do granic miasta Łodzi, styczeń 2008, za: www.zdit.uml.lodz.pl/index. php?str=65 [z dn. 01.08.2009]. 
Zachodzi zatem następująca zależność: infrastruktura zharmonizowana z zapotrzebowaniem na nia będzie stymulowała wzrost gospodarczy i rozwój społeczny, natomiast hamował go będzie brak dostosowania infrastruktury do istniejacych potrzeb. Korzyści, jakie osiagga dany region dzięki infrastrukturze podzielić można na mierzalne - pod względem wartości - i odczuwalne (np. krótszy czas przejazdu, zwiększenie liczby połączeń z danym punktem) oraz na trudne do zmierzenia, jednak o dużo większym znaczeniu gospodarczym (np. zwiększenie poziomu integracji z sasiednim miastem/regionem w wyniku usprawnienia komunikacyjnego połączenia z nim). Pozytywnym skutkiem inwestycji w nowe drogi jest często redukcja tzw. społecznych kosztów transportu, do których należa zanieczyszczenie środowiska i hałas. Bardzo istotna - być może nie doceniana przez użytkowników dróg - korzyścią wymierna jest także redukcja kosztów transportu, wynikająca z obniżenia kosztów eksploatacji pojazdu na zmodernizowanych drogach. Nie sposób nie wspomnieć także o rezultacie poprawy warunków podróżowania, jakim jest wzrost jego bezpieczeństwa.

Wszystkie z wymienionych powyżej efektów modernizacji infrastruktury odnoszą się również do omawianego przykładu miasta Łodzi.

Najważniejsze korzyści, jakie odczuli użytkownicy zmodernizowanego odcinka ulicy Pabianickiej to np. upłynnienie ruchu zarówno samochodowego, jak i tramwajowego, których trasy nie koliduja ze soba. Tramwaj jadący wytyczonym odrębnie torowiskiem (nie w obrębie pasa jezdni, jak ma to miejsce na kilku łódzkich ulicach) w żaden sposób nie utrudnia ruchu aut i odwrotnie. Nowa trakcja tramwajowa ma także duży wpływ na poprawę bezpieczeństwa ruchu pasażerów, bowiem położenie nowych torów zmniejsza bądź całkowicie eliminuje ryzyko wystapienia wypadku spowodowanego wykolejeniem się tramwaju na zużytych, powykrzywianych szynach. Prawidłowo zlokalizowano także przejścia dla pieszych - wyłącznie w obrębie skrzyżowań sterowanych sygnalizacja świetlną. Nie ma zatem możliwości, aby wysiadający ze środka komunikacji miejskiej tłum nagle zaczałł przechodzić na druga stronę jezdni, co w przypadku dużego nasilenia ruchu samochodowego mogłoby stwarzać niebezpieczeństwo.

Upłynnienie ruchu ma duże znaczenie również dla operatorów logistycznych, którzy dotąd, widząc w swoich programach zbyt duże nasilenie ruchu z centrum Łodzi w stronę Pabianic, starali się kierować swoich przewoźników bocznymi trasami - teraz ponownie moga oni powrócić na bardziej znana, główną trasę. 
Jeszcze większe możliwości w zakresie usprawnienia poruszania się pojazdów dałaby tzw. sygnalizacja akomodacyjna, czyli taka, w której światła nie zmieniają się w określonym przedziale czasowym, a w wyniku reakcji na zmianę natężenia ruchu. Skrzyżowania na opisywanym odcinku ulicy Pabianickiej sa jednak dopiero przystosowywane do tego typu sygnalizacji.

Na uwagę zasługuje też nowo wybudowane rondo, które zdaniem wielu kierowców jest rozwiązaniem lepszym, niż nawet skrzyżowanie z sygnalizacja świetlna, ponieważ lepiej rozładowuje ruch (nie występuje na nim sytuacja wstrzymania ruchu przez czerwone światło w czasie, kiedy na prostopadłej jezdni nie ma żadnych aut). Wybudowanie ronda wymusi także dalsze inwestycje - w przyszłości ma ono zostać połaczone za pomoca estakady z planowana trasa szybkiego ruchu S14. Warto przy okazji wspomnieć, że wybudowanie tej trasy oraz łączącej z nia łódzkie Chocianowice S14 było warunkiem, dla którego grupa Inter IKEA Centre Group zgodziła się zainwestować ok. 1/3 środków w modernizację ulicy Pabianickiej. Poprowadzenie w tamtych rejonach trasy szybkiego ruchu pozwoli przenieść część ruchu tranzytowego $z$ ulic miast (Łodzi i Pabianic) na jego obrzeża. Pabianice omijaliby także prawdopodobnie podróżujący w stronę Sieradza, a dalej - Wrocławia. Na S14-ce skorzystałoby także powstałe centrum handlowe, gdyż dostawcy sprawniej dowoziliby towar do sklepów na jego terenie.

Lepsza dostępność infrastrukturalna danego terenu najczęściej implikuje jego aktywizację - wzrost inwestycji. Być może polepszenie się sytuacji infrastrukturalnej w rejonie łódzkich Chocianowic także przyczyni się do zagospodarowania tamtejszych terenów rolniczych i powstania na nich np. nowego centrum logistycznego.

Ważnym przedsięwzięciem była także przebudowa mostu na rzece Ner. Modernizacja obiektu pozwoliła zwiększyć jego nośność do 50 t oraz - co za tym idzie - zaliczyć go do nowoczesnych mostów klasy A.

Elementem o dużym znaczeniu dla środowiska oraz ludzi mieszkających w rejonie Chocianowic jest nowa ścieżka rowerowa (co do której pojawiły się wprawdzie zarzuty, że mogłaby biec na dłuższym odcinku i nie kończyć się nagle - ale w chwili obecnej zawsze łatwiej będzie ją przedłużyć, niż budować od zera wzdłuż drogi, której plany w ogóle nie uwzględniałyby takiej ścieżki) oraz 876 m ekranów akustycznych, które maja minimalizować hałas, jaki wytwarza wzmożony ruch pojazdów.

Jeśli chodzi o dalsze efekty rozwojowe, to dla gospodarki regionu ogromne znaczenie miało już samo wybudowanie C.H. Port Łódź - obiektu stymulującego rozwój handlu, który z kolei oddziałuje na inne 
gałęzie przemysłu. Kierownik Portu Łódź wierzy, że oferta nowego centrum handlowego stanie się na tyle konkurencyjna dla rynku zdominowanego dotychczas przez Manufakturę i Galerię Łódzką, że zjedna sobie ono klientów zarówno z południowej części miasta, jak i z centrum. Położenie Portu jest ważne także z punktu widzenia zatrudnienia. Pracę znajdzie w nim około 2 tys. osób, które w dogodny sposób moga dotrzeć tam nie tylko z Łodzi, lecz także z Pabianic czy okolic.

\section{Podsumowanie}

W wyniku analiz przeprowadzonych w niniejszym rozdziale sformułowano następujące wnioski:

- W Polsce wciąż najpopularniejszym źródłem finansowania inwestycji infrastrukturalnych sa środki unijne. Coraz większe znaczenie zyskuje jednak tzw. partnerstwo publiczno-prywatne - forma współpracy sektora publicznego i przedsiębiorczości prywatnej, która w wielu krajach sprawdziła się i funkcjonuje od dłuższego czasu.

- Ostatnie lata były dla Łodzi korzystnym okresem pod względem liczby inwestycji zagranicznych, jakie miały miejsce na jej terenie. Za jedna z najbardziej spektakularnych uchodzi Centrum Handlowe Port Łódź z największym w Polsce sklepem IKEA.

- Na potrzeby budowy centrum handlowego dokonano istotnych zmian w przyległym odcinku infrastruktury drogowej. Modernizacja 1,5-kilometrowego odcinka drogi, której łączny koszt przekroczył $40 \mathrm{mln}$ zł, obejmowała wiele robót: drogowe, torowe, kanalizacyjne i inne.

- Rozbudowa infrastruktury przyniosła wiele wymiernych i odczuwalnych korzyści jej użytkownikom, m.in.: upłynnienie ruchu samochodowego i tramwajowego, poprawa jego bezpieczeństwa, zwiększenie nośności mostu na rzece Ner, zminimalizowanie hałasu przez ekrany akustyczne. Dla gospodarki regionu ogromne znaczenie miała też budowa samego centrum handlowego, które przyczyniło się do powstania nowych miejsc pracy, stworzenia dodatkowej konkurencji dla istniejących już dużych galerii handlowych.

- Z poprawą dostępności komunikacyjnej tej części miasta wiaże się też wizja aktywizacji i lepszego zagospodarowania leżących tam terenów rolniczych. 



\section{Charakterystyka transportu zbiorowego w Łodzi ze szczególnym uwzględnieniem okolic Teatru Wielkiego}

Jarosław Wardęcki*

\subsection{Historia rozwoju transportu miejskiego $w$ kodzi}

Początki historii komunikacji miejskiej zapoczątkowało podpisanie umowy w roku 1897 między magistratem łódzkim a grupa przemysłowców o rozpoczęciu i warunkach eksploatacji sieci tramwajowej na terenie miasta Łodzi. Dzięki podpisaniu tejże umowy powstało przedsiębiorstwo Towarzystwo Dróg Żelaznych Miejskich ${ }^{1}$.

Magistrat odstapił od pierwotnego projektu tramwaju konnego, dochodząc do wniosku, że konie będą zanieczyszczały bruki, zaś urządzenie w centrum miasta wielkich stajni będzie niehigieniczne. Uznano też, że tramwaje konne są zbyt hałaśliwe. Zatem przedstawiono władzom projekt, zgodnie $z$ którym planowano zainstalowanie $w$ Łodzi tramwajów elektrycznych. W dzień służyłyby one pasażerom, zaś w nocy wywoziły z fabryk gotowe produkty i przywoziły ciężkie ładunki, węgiel, surowce, maszyny itp. ${ }^{2}$

W związku z tym 23 grudnia 1898 r. na ulice Łodzi wyruszyły pierwsze tramwaje - na dwie linie o łącznej długości $5,8 \mathrm{~km}$. O godz. 13:00 wyruszono z zajezdni przy ulicy Nowowiejskiej (ulica ta dopiero w 1901 r. otrzymała nazwę ulicy Tramwajowej) i ulicami Dzielna, Piotrkowską przez Nowy Rynek, Średnią zajechano pod park Helenów. W tym samym dniu uruchomiono kilkanaście wagonów, którymi mogli już jeździć pasażerowie za opłata.

Na mocy umowy koncesyjnej tory tramwajowe ułożono na czterech trasach:

- od placu Kościelnego, przez Nowy Rynek, Piotrkowską do Górnego Rynku,

*Mgr Jarosław Wardęcki - Katedra Logistyki, Wydział Zarządzania Uniwersytetu Łódzkiego, ul. Matejki 22/26, 90-237 Łódź.

${ }^{1}$ M. Wojalski, 100 lat łódzkich tramwajów, Towarzystwo Opieki nad Zabytkami Oddział w Łodzi, Łódź 2002, s. 4.

2 Tamże, s. 7. 
- od cmentarzy przy ulicach Cmentarnej i Ogrodowej, Konstantynowską do Nowego Rynku,

- od parku Helenów ulica Średnia do Nowego Rynku,

- od Piotrkowskiej ulicą Dzielną do Dworca Fabrycznego i zajezdni przy Nowowysokiej (dziś Tramwajowej) ${ }^{3}$.

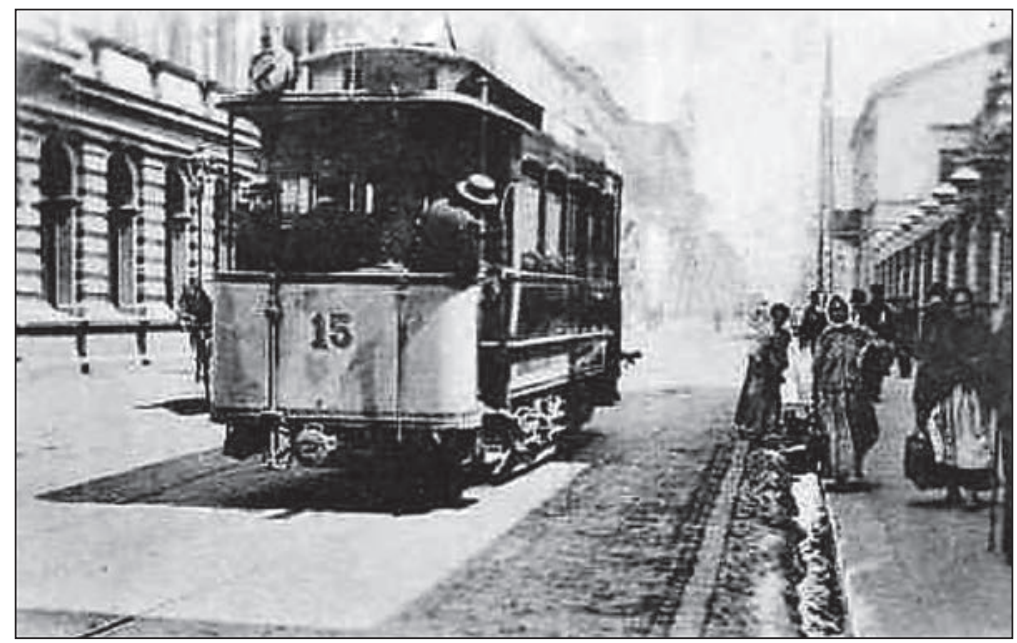

Rysunek 14. Wagon Herbrand VNB125-15 na ul. Dzielnej (obecnie ul. Narutowicza), $1900 \mathrm{r}$.

Źródło: M. Wojalski, 100 lat łódzkich tramwajów, Towarzystwo Opieki nad Zabytkami Oddział w Łodzi, Łódź 2002, s. 10

W 1899 r., pierwszym pełnym roku eksploatacji tramwajów, przewoziły one pasażerów na czterech trasach (zgodnie z koncesja) o łącznej długości 10 km; wszystkie trasy przechodziły przez ulicę Piotrkowską. Pasażerowie mieli do swojej dyspozycji 50 wagonów silnikowych i 54 wagony doczepne. Już w 1901 r. na dziesięciu liniach o długości $14,65 \mathrm{~km}$ jeździło 60 wagonów silnikowych i 42 doczepne, przewoziły one dziennie 27 tys. pasażerów, a w całym 1901 r. niemal $10 \mathrm{mln}$ pasażerów. Każda z linii przechodziła ulicą Piotrkowską, a krzyżowały się bądź rozwidlały przy skrzyżowaniach z Dzielna, Andrzeja, Główną i Radwańską. Tam też pasażerowie mieli się przesiadać.

W 1900 r. otwarto linię w kierunku Widzewa, wzdłuż ulicy Głównej. Do dnia dzisiejszego, a więc od 100 lat, z tą trasa - na Widzew - zwiazany jest tramwaj linii 10 .

${ }^{3}$ Tamże, s. 28. 
Także w 1900 r. ruszyły tramwaje na ulicy Andrzeja, Długiej i Milsza (do rogu Łąkowej). Nieco później na Widzewskiej (obecna ulica J. Kilińskiego) od ulicy Głównej, Zarzewską do Rynku Geyera oraz na Pańskiej i Radwańskiej.

Ponadto w 1901 r. Towarzystwo Dróg Żelaznych Miejskich zmieniło nazwę na Towarzystwo Kolei Elektrycznej Łódzkiej.

W końcu 1903 r. tramwaje przewoziły pasażerów już na dziewięciu liniach, z których cztery miały krańcówkę na placu Kościelnym (1, 2, 6 i 10), również cztery na Górnym Rynku (1, 3, 4 oraz 7), po dwie na: Widzewie $(9,10)$, Milsza $(5,6)$, Helenowie $(2,7)$, Tramwajowej $(2,7)$, krańcówka dla linii 9 była na skrzyżowaniu Głównej i Piotrkowskiej, zaś 3 przy cmentarzach. W końcu 1914 r. było także dziewięć linii, ale znacznie rozbudowany był ich układ. W okolice Dworca Kaliskiego, a dokładnie w rejon obecnego skrzyżowania ulicy Kopernika i alei Włókniarzy tramwaje dotarły dopiero w październiku $1913 \mathrm{r}$.

W czerwcu 1923 r. została podpisana umowa koncesyjna między władzami miasta Łodzi a zarządem Kolei Elektrycznej Łódzkiej, w której zawarto nowy program rozwoju sieci tramwajowej. Program przewidywał $\mathrm{m}$.in. budowę trasy na ulicy Zielonej - od ulicy Piotrkowskiej do ulicy Leszno (obecnie Żeligowskiego). Budowa tej trasy została zatwierdzona do realizacji w czerwcu 1927 r. Okazało się jednak, że skrzyżowanie ulic Piotrkowskiej, Zielonej i Narutowicza jest zbyt małe na budowę skomplikowanego węzła torowego ze skrzyżowaniem torów pod kątem prostym i rozjazdami we wszystkich kierunkach. Na budowę nowego węzła wybrano więc najbliżej położone na południe skrzyżowanie ulicy Piotrkowskiej z ulicą 6 Sierpnia. Tory miały przebiegać właśnie ulica 6 Sierpnia, następnie skręcać w aleję Kościuszki do ulicy Zielonej.

27 stycznia 1928 r. na trzydziestym szóstym posiedzeniu zarządu Spółki KEŁ podjęto decyzję o budowie nowej trasy tramwajowej na ulicach: Czerwonej, Wólczańskiej i Kątnej (obecnie Wróblewskiego) do Proletariackiej. Wkrótce przystąpiono do budowy. Na skrzyżowaniu ulic Piotrkowskiej i Czerwonej ułożono łuki w relacji północno-zachodniej. Tory na ulicy Czerwonej przebiegały środkiem brukowej jezdni, następnie skręcały na południe w ulicę Wólczańską. Pierwotny układ torów przetrwał aż do II połowy lat 60. XX w. Tramwaje na nowej trasie ruszyły 16 listopada 1928 r. Pierwszą linia, która kursowała ulica Czerwona była linia 14. Około $1941 \mathrm{r}$. jej miejsce zajęła na długie lata linia 6. W okresie okupacji ulica nosiła nazwę Rotgarnstrasse.

Lata przed wybuchem II wojny światowej nie wykazują już znaczniejszej rozbudowy sieci. W 1934 r. powstaja niewielkie odcinki nowych 
torów: przedłużenie ulicy Narutowicza od ulicy Tramwajowej do ulicy Zagajnikowej i na ulicy Łagiewnickiej od Bałuckiego Rynku do ulicy Biegańskiego. Dopiero w latach 1945-1946 linie tramwajowe miejskie wydłużono do przedmieścia: Zdrowie, Ruda Pabianicka, Żabieniec i Julianów. Po II wojnie światowej nastapił dalszy rozwój łódzkiej komunikacji miejskiej. Powstały nowe trasy: Stoki, Nowe Złotno, Karolew, na ulicy Łagiewnickiej, Warszawskiej i Wojska Polskiego. W 1951 r. tramwaje pojawiły się na całej długości alei Kościuszki i ulicy Zachodniej, odciążając bardzo zatłoczoną Piotrkowska, co pozwoliło nawet na likwidację tramwajów na odcinku od placu Wolności do ulicy Franciszka Żwirki.

Historia łódzkiej komunikacji autobusowej sięga 1948 r. (jest krótsza od tramwajowej o równe 50 lat). 11 października 1948 r. została uruchomiona pierwsza w mieście linia autobusowa "A" na odcinku: plac Niepodległości-Józefów, a następnie od toru kolejowego do Józefowa wzdłuż ulicy Rzgowskiej.

W 1951 r. ruszyła następna linia autobusowa po ulicy Piotrkowskiej między placami Wolności i Niepodległości. Dzięki rozbudowie torów wydłużono trasę tramwajową do Zagrzewa.

W roku 1959 zapoczątkowano budowę zajezdni autobusowej zlokalizowanej pomiędzy ulicami: Kraszewskiego (strona wschodnia), Przyborowskiego (strona południowa) i Kilińskiego (strona zachodnia), która ukończono w roku 1961. Od strony północnej zajezdnia graniczyła z Zakładem Torów i Sieci. Ważnym wydarzeniem dla komunikacji autobusowej było wybudowanie w 1986 r. trzech nowych zajezdni.

Dawniej po ulicach Łodzi poruszały się następujące autobusy:

- Fiat 666RN Urbano - w liczbie 7 sztuk od roku 1948-1950,

- Büssing NAG - jedna sztuka od roku 1950 do 1953,

- Malag TR5 - 11 sztuk w latach 1950-1960,

- Star 52 - 16 sztuk w latach 1956-1961,

- San H01B - 87 sztuk w latach 1958-1967,

- Ikarus 620 - 258 sztuk w latach 1959-1978,

- San H25B - 19 sztuk w latach 1962-1967,

- Jelcz 043 - 49 sztuk w latach 1963-1982,

- Jelcz 272Mex - w liczbie 640 sztuk w latach 1963-1984,

- Jelcz 021 - w liczbie 33 sztuk w latach 1968-1979; były to pierwsze w historii łódzkiej komunikacji pojazdy przegubowe,

- Ikarus 556 - w liczbie 29 sztuk w latach 1969-1979,

- Jelcz PR-110U - w liczbie 315 sztuk w latach 1976-19924.

${ }^{4}$ http://mkmlodz.webd.pl/stronataborautobusy.htm [z dn. 29.10.2011]. 


\subsection{Opis systemu komunikacji miejskiej}

Na terenie Łodzi dominująca firmą przewozowa jest Miejskie Przedsiębiorstwo Komunikacyjne Sp. z o.o. Jest to jednoosobowa spółka gminy Miasta Łódź. Spółka ta prowadzi działalność od 1 stycznia 1993 r. Jej podstawowymi zadaniami sa w szczególności:

- świadczenie usług przewozowych w zakresie komunikacji miejskiej, zamówionych przez Zarząd Miasta Łodzi, wraz z obsługa pasażera,

- świadczenie usług transportowych dla osób niepełnosprawnych pojazdami specjalistycznymi,

- wykonywanie planowanych zadań w zakresie sprzedaży biletów,

- wykonywanie planowanych zadań w zakresie konserwacji, przegladów technicznych,

- prowadzenie prac zleconych przez gminę, w tym jako inwestora zastępczego $w$ realizacji inwestycji.

Łódzkie MPK dysponuje 378 autobusami. Po trasach miasta Łodzi jeżdża następujące autobusy: 62 sztuki Solaris Urbino 18, 14 sztuk Volvo 7700A, 5 sztuk Volvo 7700, 12 sztuk Mercedes-Benz 0530 Citaro, 7 sztuk Mercedes-Benz 0530 G Citaro, 30 sztuk Mercedes-Benz 0345 G Conecto, 17 sztuk Jelcz M081 „Vero”, 30 sztuk Jelcz M121MB3, 15 sztuk Volvo 7700A, 40 sztuk Volvo 7000, 24 sztuki Mercedes-Benz 0530 Citaro, 34 sztuki Volvo B10L, 28 sztuk Mercedes-Benz 405N2, 30 sztuk Mercedes-Benz 0405 GN, 26 sztuk Ikarus $280^{5}$.

Najnowocześniejszym autobusem, jaki porusza się po łódzkich drogach, jest Solaris Urbino 18. Jest to autobus napędzany silnikiem spalinowym o mocy $231 \mathrm{~kW}$, spełnia on normy spalin Euro 5. Autobus ten został wyprodukowany w $2008 \mathrm{r}$.

Omawiane przedsiębiorstwo dysponuje również 456 wagonami tramwajowymi. W skład tego taboru wchodzą następujące tramwaje: 10 sztuk Pesa 122, 4 tramwaje 805Na ze zmodernizowanym napędem i designem, 106 tramwajów 805Na ze zmodernizowanym designem, 15 Cityrunnerów, 25 tramwajów 805NA ze zmodernizowanym napędem, 296 tramwajów 805 $\mathrm{Na}^{6}$.

Funkcjonujący w Łodzi system transportu zbiorowego składa się z systemu komunikacji tramwajowej i autobusowej. Komunikacja tramwajowa operuje na 21 liniach dziennych o sumarycznej długości około $516 \mathrm{~km}$ (liczonych oddzielnie dla każdego kierunku jazdy), przy czym długość torowisk tramwajowych to około $155 \mathrm{~km}$ toru pojedynczego

\footnotetext{
${ }^{5}$ www.mpk.lodz.pl/showarticleslist.action?category=1134\&Autobusy [zdn. 29.10.2011].

${ }^{6}$ www.mpk.lodz.pl/showarticleslist.action?category $=1133$ [z dn. 29.10.2011].
} 
plus 19 pętli końcowych. W godzinach szczytu w ruchu jest 161 tramwajów. MPK Łódź dysponuje 456 wagonami tramwajowymi.

Komunikacja autobusowa natomiast obejmuje 72 linie dzienne o sumarycznej długości około $872 \mathrm{~km}$ oraz 8 linii nocnych o sumarycznej długości $217 \mathrm{~km}$. W godzinach szczytu w ruchu jest 228 autobusów?.

W Łodzi oprócz MPK swoje usługi oferują również inni przewoźnicy. Sa to małe przedsiębiorstwa, takie jak:

- MKT Sp. z o.o. - Międzygminna Komunikacja Tramwajowa jako samodzielny podmiot istnieje już od 1993 r. Kontynuuje tradycje ponad stuletniej łódzkiej podmiejskiej komunikacji tramwajowej. Firma jest zlokalizowana w Łodzi przy ulicy Zgierskiej 256. Spółka MKT prowadzi regularna działalność przewozową na najdłuższej linii tramwajowej w Polsce, łączącej trzy miasta: Łódź, Zgierz, Ozorków. Firma dysponuje trzema liniami, w tym dwiema tramwajowymi oraz jedna autobusową. Linia tramwajowa 46 kursuje z Chocianowic przez Łódź do Zgierza i Ozorkowa; linia autobusowa 46 bus kursuje z Łodzi (plac Wolności) przez Zgierz do Ozorkowa, zaś linia tramwajowa 46A kursuje z Chocianowic i dojeżdża do zajezdni Helenówek. Firma również oferuje wynajem autobusów oraz powierzchni reklamowych na tramwajach. Od 1 kwietnia 2012 r. spółka znajduje się w likwidacji,

- PKS Łódź Sp. z o.o. - firma zlokalizowana jest w Łodzi przy ulicy Smutnej 28. Przedsiębiorstwo Komunikacji Samochodowej poza przewozem osób świadczy również usługi: diagnozowania pojazdów, naprawy pojazdów, turystyki krajowej i zagranicznej, detalicznej sprzedaży paliw oraz sprzedaży winiet. PKS dysponuje dużą liczbą autobusów oraz własna stacja naprawy i diagnozowania,

- Tramwaje Podmiejskie Sp. z o.o. - firma jest zlokalizowana przy ulicy Konstantynowskiej 115 w Łodzi. Prowadzi swoja działalność na terenie powiatu pabianickiego, a także na obszarze miasta Łodzi. Po łódzkich drogach poruszaja się dwie linie dzienne: 43 i 43bis. Obydwie swoja krańcówkę mają zlokalizowaną na Stokach, natomiast linia 43 kursuje do Lutomierska, zaś 43bis kursuje tylko do Konstantynowa Łódzkiego. W chwili obecnej do obsługi pasażerów na liniach 43 i $43 \mathrm{bis}$ wykorzystywane sa tramwaje typu GT-6 oraz tramwaje typu 803N, przyjęte do eksploatacji w Łodzi od 1990 r. Ponadto firma oferuje: przewozy autokarowe, wynajem autokarów, reklamę na tramwajach oraz na panelach reklamowych wiat przystankowych. Poza tym posiada na wyposażeniu: busy Ford Transit oraz Kapena Thesi Intercity.

\footnotetext{
${ }^{7}$ Ze zbiorów Muzeum Komunikacji Miejskiej MPK-Łódź [z dn. 10.05.2010].
} 
Kursują one na trasie z Konstantynowa Łódzkiego do Pabianic. Od 1 kwietnia 2012 r. spółka znajduje się w likwidacji,

- MZK Pabianice Sp. z o.o. - siedziba firmy mieści się przy ulicy Lutomierskiej w Pabianicach. W obecnej chwili firma dysponuje 34 autobusami. Na potrzeby pasażerów uruchomiła linię autobusową N, która kursuje na trasie od Dworca PKP w Pabianicach do dworca Łódź Fabryczna przy ulicy Węglowej,

- MUK Zgierz - Miejskie Usługi Komunikacyjne w Zgierzu są zakładem budżetowym Gminy Miasta Zgierz. Zakład uruchomił linię autobusową 6, która kursuje z Łodzi Kaliskiej do Zgierza na ulicę Staffa. Ponadto do głównych zadań MUK należą: organizacja miejskiej komunikacji autobusowej i tramwajowej, dystrybucja i kontrola biletów, okresowe przeprowadzanie zmian $\mathrm{w}$ rozkładach jazdy stosownie do potrzeb pasażerów, administrowanie przystankami oraz współpraca z innymi gminami,

- Express-Bus - oferuje linie regularne oraz wycieczki, ponadto firma w swojej ofercie posiada zorganizowany przewóz pracowników do miejsc pracy,

- Kris-Tour ABC Sp. z o.o. - firma zlokalizowana jest w Tuszynie przy ulicy Młynkowej. Spółka oferuje wynajem autokarów o wysokim standardzie. Posiada w swojej ofercie również przewozy na liniach podmiejskich, obsługuje centra handlowe i hipermarkety, wśród nich największe centrum handlowe w Polsce - Manufaktura,

- Polmix - współpracuje z firma MS Kris; wspólnie organizuja przewozy osobowe z Łodzi do Pabianic. Firma MS Kris jest zlokalizowana w Rzgowie, w swojej ofercie posiada wynajem komfortowych busów oraz świadczenie usług przewozowych na regularnych liniach. Działa od 1995 r.,

- Iwa-Trans - oferuje przewozy autokarowe krajowe i zagraniczne oraz wynajem autokarów,

- Trans-Bus - wynajem mikrobusów oraz przewozy osobowe busami i autokarami,

- Mila-Tour - firma oferuje następujące usługi: wynajem autobusów, transport wycieczek, ponadto świadczy usługi na podmiejskiej linii Łódź-Borowa,

- P.H.U. Jar-Pol - firma zlokalizowana jest w Łodzi. Zajmuje się licencjonowanym krajowym transportem w zakresie przewozu osób. Jar-Pol posiada zezwolenie na przewóz osób na liniach regularnych w województwie łódzkim. Ponadto $w$ ofercie ma również: dowóz 
pracowników, wyjazdy firmowe, wycieczki szkolne i wynajem busów.

Firma realizuje przewozy na terenie Polski oraz międzynarodowe.

\subsection{Charakterystyka systemu transportu miejskiego w okolicach placu Dąbrowskiego}

Plac im. gen. Henryka Dąbrowskiego zlokalizowany jest w centrum Łodzi, ograniczony ulicami Sterlinga, Jaracza i Narutowicza. Plac ten pełnił w XIX wieku rolę centrum sprzedaży pobliskiej cegielni, stąd jego nazwa - Rynek Cegielniany Wielkomiejski.

Wizerunek placu zaczął się zmieniać w XX wieku. W latach 1927-1930 stanał Sąd Okręgowy - obecnie Sąd Apelacyjny, zajmując część wschodnią budynków ustawionych w szeregu po jednej stronie placu. Na środku placu w latach 60. wybudowano Teatr Wielki.

Obecnie główną atrakcja placu Dąbrowskiego jest efektowna fontanna w kształcie morskiej fali, która została oficjalnie otwarta 24 sierpnia 2009 r. Plac przy ulicy Narutowicza ma już nową nawierzchnię, a po bokach nowe latarnie i ławki.

Plac Dąbrowskiego to także duży węzeł komunikacyjny, zatrzymuje się tu kilkanaście linii tramwajowych i autobusowych. Wraz z przebudowa ulic wokół placu powstał wspólny przystanek dla obu środków lokomocji. W wyniku tej inwestycji likwidacji uległa krańcówka, która została przeniesiona pod budynek Dworca Fabrycznego.

W najbliższym sąsiedztwie opisanego placu znajdują się następujace przystanki linii tramwajowych: 7, 9, 12, 13 oraz autobusowych: 51, $51 \mathrm{~A}, 53,57,86$.

Na ulicy Jaracza przebiega linia autobusowa 70, 70A oraz 96. Przy dworcu Łódź Fabryczna zlokalizowane są przystanki następujących linii: $53,58,60,60 \mathrm{~A}, 60 \mathrm{~B}, 46$ bus, 51 oraz linia N. Linia 46 bus należy do firmy MKT Sp. z o.o., linia N do MZK Pabianice, natomiast linia 51 - do Miejskich Usług Komunikacyjnych w Zgierzu. Ponadto po ulicy Kopcińskiego poruszaja się następujące linie autobusowe MPK: 56, 67, 85A oraz 85.

Linie tramwajowe $\mathrm{w}$ Łodzi sa dość gęsto rozlokowane, w związku z tym w okolicach placu Dąbrowskiego przebiega kilka linii. Najbliżej sąsiadującym z placem jest dworzec Łódź Fabryczna, przy którym zatrzymuja się następujace linie: 1, 4 oraz 5. Na ulicy Pomorskiej poruszają się tramwaje linii 15 oraz linii 43, która kursuje z Lutomierska i linia 43bis, która kursuje z Konstantynowa Łódzkiego - obydwie dojeżdżaja do Stoków, gdzie zlokalizowana jest ich krańcówka. 


\section{Podsumowanie}

W wyniku analiz przeprowadzonych w niniejszym rozdziale sformułowano następujące wnioski:

- Sprawnie działająca i nowoczesna sieć transportu miejskiego może w dużym stopniu rozwiązać problem komunikacyjny dużych aglomeracji miejskich.

- Transport szynowy, jako główne ekologiczne źródło komunikacji w mieście, jest podstawa neutralizacji negatywnego oddziaływania transportu na środowisko naturalne.

- Kooperacja w ramach logistyki miejskiej w dłuższej perspektywie umożliwia rozwój miasta i przyczynia się do jego sukcesu społeczno-gospodarczego.

- Transport szynowy i autobusowy przyczynia się do odciążenia transportu samochodowego w mieście.

- Dażenie do unowocześnienia infrastruktury transportu publicznego polepsza funkcjonowanie transportu w mieście oraz zwiększa atrakcyjność danego miasta.

- Sprawna organizacja przewozów osobowych na terenie miasta jest podstawa mobilności jego mieszkańców oraz przyjezdnych i przesadza o sile związków miasta z regionem w sferze społecznej.

- Transport multimodalny pozwala na optymalizację procesów związanych z przemieszczaniem się i zmniejsza problemy związane z kongestia oraz ograniczenia istniejacej infrastruktury.

- Zapobieganie nadmiernemu użytkowaniu samochodów oraz zatłoczeniu ulic i parkingów powinno być wspomagane poprzez ograniczenia swobody ruchu indywidualnego za pomoca środków prawnych i opłat.

- Planowanie i realizowanie potrzeb transportowych z jednej strony poprawia dostępność infrastruktury oraz środków transportu, co sprzyja społecznemu zadowoleniu i uatrakcyjnia miejski styl życia, a z drugiej - przyczynia się do sprawniejszej realizacji priorytetowych zadań przy wykorzystaniu ekologicznych środków transportu w mieście.

W związku z powyższym, w wyniku przeprowadzonych przez autora obserwacji można śmiało stwierdzić, iż szczegółowa analiza logistyki miejskiej, a co za tym idzie, także komunikacji miejskiej, będzie stanowić w przyszłości o sukcesach rozwojowych danych miast i regionów. 



\title{
8. Współczesne kierunki ewolucji transportu miejskiego
}

\author{
Magdalena Maciaszek*
}

\subsection{Podział środków transportu miejskiego}

"Transport jest działalnością mająca na celu pokonywanie przestrzeni" $^{\prime \prime}$. W aspekcie ekonomicznym transport polega na świadczeniu odpłatnych usług, w wyniku których przemieszczane są osoby i ładunki, przy jednoczesnym tworzeniu usług pomocniczych².

W zależności od przyjętego kryterium możemy dokonać podziału środków transportu. Ze względu na przedmiot przewozu ${ }^{3}$ wyróżniamy:

- transport osób,

- transport ładunków.

Warto zauważyć, iż wszystkie gałęzie transportu, za wyjątkiem transportu rurociaggowego, pozwalaja na przewóz zarówno osób, jak i ładunków.

Kolejnym kryterium podziału są względy organizacyjno-funkcjonalne ${ }^{4}$. Mamy więc:

- transport regularny,

- transport nieregularny.

Transport regularny charakteryzuje się ustalonym, podanym do publicznej wiadomości rozkładem jazdy. Przewóz odbywa się systematycznie, o określonym czasie. Natomiast w przypadku transportu nieregularnego, jest on realizowany wówczas, gdy wystapi zapotrzebowanie. Zarówno transport regularny, jak i nieregularny występuje we wszystkich gałęziach transportu. Na przykład $w$ transporcie lotniczym mamy przewozy liniowe oraz czarterowe, w transporcie samochodowym - przewozy według ustalonego rozkładu jazdy oraz przewozy okazjonalne (np. wycieczkowe).

* Mgr Magdalena Maciaszek - Katedra Logistyki, Wydział Zarządzania Uniwersytetu Łódzkiego, ul. Matejki 22/26, 90-237 Łódź.

${ }^{1}$ W. Rydzykowski, K. Wojewódzka-Król, Transport, PWN, Warszawa 2005, s. 1.

2 Tamże.

${ }^{3}$ A. Koźlak, Ekonomika transportu. Teoria i praktyka gospodarcza, Wyd. Uniwersytetu Gdańskiego, Gdańsk 2007, s. 14-17.

${ }^{4}$ Tamże, s. 14. 
Następnym kryterium jest ciągłość procesu transportowego5. Tu wyróżniamy:

- transport bezpośredni,

- transport pośredni

W przypadku transportu bezpośredniego przewóz odbywa się za pomoca tylko jednego środka transportu i jest realizowany bez przeładunków w trakcie przewozu. W transporcie pośrednim zaś wykorzystywany jest więcej niż jeden środek transportu.

Dalszym wyznacznikiem jest zasięg geograficzny. W ramach tego kryterium wyróżniamy ${ }^{6}$ :

- transport międzynarodowy,

- transport krajowy.

W pierwszym przypadku wyodrębnia się transport kontynentalny i międzykontynentalny, a w transporcie krajowym - m.in. miejski, wojewódzki, wewnatrzzakładowy.

Transport miejski pod względem technicznym nie jest wyodrębniany jako osobna gałaź transportu. Definiowany jest na podstawie poziomej klasyfikacji transportu, według której dotyczy on operacji transportowych dokonywanych na danym obrębie terytorialnym oraz jego specyficznej problematyki eksploatacyjno-ekonomicznej. Systemy transportu miejskiego stanowią podstawę zapewnienia przepustowości oraz płynności przepływu ludzi i towarów?

Szczególną uwagę zwraca określenie „miejski”. Termin ten nie jest do końca adekwatny, ponieważ obejmuje on nie tylko miasto w jego granicach administracyjnych, lecz także bezpośrednio graniczące tereny podmiejskie. W dużej części są to obszary posiadające ośrodki lub placówki, z usług których korzystaja mieszkańcy danego miasta. W przypadku tworzenia się i rozwoju zespołów miast zasięg działania transportu miejskiego jest znacznie większy

Systematyzując zatem - transport miejski to zespół czynności pozwalających na przemieszczanie się osób i dóbr materialnych za pomoca odpowiednich środków w obrębie miasta9 .

5 Tamże.

${ }^{6}$ Tamże, s. 15.

7 M. Szymczak, Transport miejski, [w:] E. Gołembska (red.), Kompendium wiedzy o logistyce, Wyd. Naukowe PWN, Warszawa 2004, s. 306.

8 O. Wyszomirski, Transport miejski, [w:] W. Rydzkowski, K. Wojewódzka-Król (red.), Transport, PWN, Warszawa 2005, s. 220.

${ }_{9}$ M. Matulewski, S. Konecka, P. Fajfer, A. Wojciechowski, Systemy logistyczne, Instytut Logistyki i Magazynowania, Poznań 2008, s. 246. 
W transporcie miejskim wykorzystywane są środki transportu należące do różnych jego gałęzi ${ }^{10}$. Wyróżnić można:

- środki transportu szynowego, np. metro, tramwaje, koleje,

- środki transportu drogowego, np. autobus, samochód osobowy.

Środki służące do przewozu wykorzystywane w transporcie miejskim moga być sklasyfikowane pod względem funkcjonalnym oraz technicznym ${ }^{11}$.

W podziale funkcjonalnym kryterium podziału jest sposób wykorzystania środka. Według tego aspektu wydziela się środki ${ }^{12}$ :

- indywidualne (rower, motor, motorower, samochód osobowy),

- grupowe (używane wspólnie przez kilku pasażerów, np. taksówka, mikrobus),

- zbiorowe (autobus, tramwaj, metro, kolej miejska, kolej regionalna).

Innym kryterium podziału środków transportu miejskiego sa zasady prowadzenia tras oraz rodzaj energii napędowej ${ }^{13}$. Wyróżnia się środki transportu:

- naziemne napędzane silnikami spalinowymi, np. autobus, motocykl,

- naziemne napędzane energia elektryczna pochodząca z trakcji elektrycznych umieszczonych nad trasą linii, np. trolejbus,

- naziemne kursujace po torowiskach bezpośrednio wbudowanych w jezdnie lub znajdujących się pomiędzy pasami ruchu, napędzane energia elektryczna, np. tramwaj,

- podziemne korzystajace z tuneli znajdujących się pod ulica.

$Z$ powyższych podziałów można wywnioskować, że niektóre środki transportu należą do więcej niż jednej kategorii.

Biorąc pod uwagę funkcjonalność środków transportowych służących do obsługi komunikacji miejskiej, najczęściej używa się takich kryteriów, jak ${ }^{14}$ :

- prędkość ruchu,

- zapotrzebowanie terenowe,

- zdolność przewozowa,

- zużycie energii,

- wpływ na środowisko.

10 Tamże, s. 247.

${ }^{11}$ O. Wyszomirski, Transport miejski, s. 221.

12 Tamże, za: W. Suchorzewski (red.), Planowanie systemów transportu miejskiego, Instytut Gospodarki Przestrzennej i Komunalnej, Warszawa 1991, s. 11.

13 O. Wyszomirski, Transport miejski, s. 221.

14 Tamże, s. 222. 
Każdy z środków transportu miejskiego charakteryzuje się innymi wymogami dotyczącymi wyżej wymienionych kryteriów. W tab. 16 zostały sklasyfikowane podstawowe wady i zalety środków komunikacji miejskiej.

Tabela 16. Wady i zalety poszczególnych środków komunikacji miejskiej

\begin{tabular}{|c|c|c|}
\hline $\begin{array}{c}\text { Środek } \\
\text { komunikacji }\end{array}$ & Zalety & Wady \\
\hline Tramwaj & $\begin{array}{l}\text { - niski koszt eksploatacji } \\
\text { - duża pojemność } \\
\text { - bezkolizyjność } \\
\text { - szybkość } \\
\text { - punktualność } \\
\text { - ekologia }\end{array}$ & $\begin{array}{l}\text { - kosztowna infrastruktura } \\
\text { - konieczność tworzenia odrębnej } \\
\text { infrastruktury } \\
\text { - efektywny przy dużym natężeniu } \\
\text { ruchu } \\
\text { - hałaśliwość } \\
\text { - awaryjność } \\
\text { - niska dostępność przestrzenna }\end{array}$ \\
\hline Autobus & $\begin{array}{l}\text { - duża pojemność } \\
\text { - brak konieczności tworzenia } \\
\text { dodatkowej infrastruktury } \\
\text { - łatwość uruchamiania nowych } \\
\text { tras } \\
\text { - możliwość dostosowania do natę- } \\
\quad \text { żenia ruchu }\end{array}$ & $\begin{array}{l}\text { - wysoki koszt eksploatacji } \\
\text { - kolizyjność } \\
\text { - niska szybkość } \\
\text { - niska punktualność } \\
\text { - negatywny wpływ na środowisko } \\
\text { - niski komfort jazdy }\end{array}$ \\
\hline $\begin{array}{l}\text { Kolej } \\
\text { miejska/ } \\
\text { metro }\end{array}$ & $\begin{array}{l}\text { - bardzo duża pojemność } \\
\text { - bezkolizyjność } \\
\text { - wysoka szybkość } \\
\text { - duża punktualność } \\
\text { - ekologia }\end{array}$ & $\begin{array}{l}\text { - efektywny przy dużym natężeniu } \\
\text { ruchu } \\
\text { - długi okres powstawania } \\
\text { - zagrożenie zamachami } \\
\text { terrorystycznymi }\end{array}$ \\
\hline $\begin{array}{l}\text { Transport } \\
\text { indywidualny }\end{array}$ & $\begin{array}{l}\text { - ogromna swoboda ruchu } \\
\text { - brak konieczności wydzielania } \\
\text { odrębnej infrastruktury } \\
\text { - wygoda }\end{array}$ & $\begin{array}{l}\text { - niska pojemność } \\
\text { - duża terenochłonność } \\
\text { - wysoki koszt przemieszczania } \\
\text { - kolizyjność } \\
\text { - negatywny wpływ na środowisko } \\
\text { - zagrożenie wypadkami }\end{array}$ \\
\hline
\end{tabular}

Źródło: opracowanie własne na podstawie: M. Szymczak, Logistyka miejska, Wyd. Akademii Ekonomiczna w Poznaniu, Poznań 2008, s. 119-120.

Przewaga poszczególnych środków transportu miejskiego jest zróżnicowana pod względem funkcjonalności. Każdy z wymienionych środków transportu ma szereg zalet, ale również posiada mankamenty. W dzisiejszych czasach duży nacisk kładzie się na możliwość odbywania intermodalnych podróży miejskich. Zagadnienie kombinowanych podróży miejskich jest szerzej omówione w podrozdziale 9.4. 


\subsection{Potrzeby komunikacyjne mieszkańców ośrodków zurbanizowanych}

Pojęcie "potrzeby komunikacyjnej” rozumiane jest jako "chęć, potrzeba czy też żądanie jednostki lub określonej zbiorowości dotyczące realizacji procesu przemieszczania się z jednego miejsca na drugie"15.

Funkcjonowanie ośrodków zurbanizowanych jest połączone z koniecznością umożliwienia mieszkańcom przemieszczania się, bez względu na potrzebę komunikacyjna ${ }^{16}$. Problematyka zaspokajania potrzeb przewozowych za pomoca transportu jest bardzo złożonym zagadnieniem. W przeciwieństwie do podstawowych potrzeb (np. biologicznych, kulturalnych czy socjologicznych), potrzeby transportowe sa powiązane z produkcyjną i społeczną aktywnością człowieka. W przypadku transportu pasażerskiego na popyt silnie oddziałuje zmieniający się charakter aktywności człowieka, która wymaga transportu ${ }^{17}$.

Potrzeby komunikacyjne moga być podzielone według różnych kryteriów. Do najistotniejszych zaliczyć można ${ }^{18}$ :

- charakter potrzeby pierwotnej, np. potrzeba związana z praca, życiem kulturalnym lub towarzyskim,

- konieczność zaspokojenia potrzeby obligatoryjnej (np. związanej z dojazdem do pracy, szkoły) lub fakultatywnej (np. związanej z rekreacja),

- czas przeznaczony na zaspokojenie potrzeby,

- relację przestrzenna.

Na kształtowanie się potrzeb przewozowych ma wpływ zbiór czynników wzajemnie ze soba powiazzanych ${ }^{19}$, takich jak:

- wielkość aglomeracji miejskiej,

- struktura przestrzenno-funkcjonalna,

- stopień aktywności ludności,

- struktura demograficzna ludności,

- poziom dochodów ludności,

${ }^{15}$ S. Dziadek, Systemy transportowe ośrodków zurbanizowanych, PWN, Warszawa 1991, s. 106 za: Z. Pawlicka, Przewozy pasażerów, Wyd. Komunikacji i Łączności, Warszawa 1979.

${ }^{16}$ J. Szołtysek, Logistyczne aspekty zarządzania przepływami osób i ładunków w miastach, Wyd. Akademii Ekonomicznej w Katowicach, Katowice 2005, s. 120.

${ }_{17}$ A. Koźlak, Kierunki zmian w planowaniu rozwoju transportu w miastach jako efekt dążenia do zrównoważonego rozwoju, "Transport Miejski i Regionalny" 2009, nr 7-8, s. 39.

${ }_{18}$ M. Szymczak, Logistyka miejska, Wyd. Akademii Ekonomicznej w Poznaniu, Poznań 2008, s. 108.

${ }^{19}$ M. Matulewski, S. Konecka, P. Fajfer, A. Wojciechowski, Systemy logistyczne, s. 248. 
- ilość wolnego czasu ludności.

Wśród globalnie zgłaszanych potrzeb można wyodrębnić zindywidualizowaną potrzebę ${ }^{20}$ związaną $z$ :

- konkretna potrzeba pierwotna, powodująca daną potrzebę transportowa,

- konkretną odległością przestrzenna, ekonomiczna, czasową między punktem początkowym a końcowym,

- poszczególnym pasażerem lub grupa pasażerów.

Popyt na przewozy transportem miejskim odzwierciedla potrzeby przewozowe. Efektem zaspokojenia tego popytu sa podróże komunikacyjne i przejazdy. Pojęcie przejazdu zawiera się w pojęciu podróży komunikacyjnej. Różnica polega na tym, że podróż jest przemieszczaniem się w relacji "od drzwi do drzwi” - obejmuje dojście do przystanku oraz celu podróży, czas oczekiwania na środek transportu, jazdę, przesiadanie się $e^{21}$.

Cechami charakterystycznymi popytu zgłaszanego wobec transportu miejskiego są2:

- ograniczenie przestrzenne warunkujące niedużą średnią odległość podróży,

- powszechność,

- masowość,

- nierównomierność czasoprzestrzenna.

$\mathrm{Na}$ odległość wykonywanych podróży ma wpływ zagospodarowanie przestrzenne terenu. Chodzi tutaj o odległości, jakie muszą pokonać mieszkańcy, aby dotrzeć do pracy, szkoły czy też miejsca rozrywki. Odległość ta przeciętnie wynosi od kilku do kilkunastu kilometrów.

Powszechność potrzeb przewozowych odzwierciedla wskaźnik ruchliwości komunikacyjnej mieszkańców. Wskaźnik ten oznacza średnią liczbę podróży przypadającą na jednego mieszkańca w ciągu doby. Nierównomierność czasoprzestrzenna wynika z wahań godzinowych w ciągu doby czy też dziennych w ciągu tygodnia. Wahania te doskonale widoczne są w czasie, kiedy mieszkańcy dojeżdżają lub powracaja do/z miejsca pracy. Natomiast nierównomierność przestrzenna jest widoczna w postaci wahań kierunkowych, które są wywołane rozmieszczeniem przestrzennym ${ }^{23}$.

${ }^{20}$ T. Kusiakiewicz, Region jako ośrodek generujący popyt na przewozy, "Transport Miejski i Regionalny" 2009, nr 2, s. 20.

${ }^{21}$ O. Wyszomirski, Transport miejski, s. 231.

22 Tamże, s. 232.

23 Tamże. 
Relację pomiędzy potrzebami komunikacyjnymi, popytem a realizowanymi przewozami można przedstawić za pomocą nierówności24:

$$
\text { potrzeby } \geq \text { popyt } \geq \text { przewozy }
$$

Aby popyt na przewozy transportem miejskim był zaspokojony, potrzebne jest spełnienie określonych wymagań dotyczacych warunków podroży. Warunki te nazwane są postulatami przewozowymi. Rodzaj i liczba zgłaszanych postulatów ulega ciagłej zmianie. Zależy od aktualnych warunków przewozowych, statusu podróżnego i poziomu życia w mieście ${ }^{25}$. Najczęściej wymieniane w literaturze postulaty ${ }^{26}$ to:

- częstotliwość,

- prędkość,

- koszt,

- komfort podróży,

- bezpieczeństwo,

- wygoda,

- niezawodność.

Dodatkowo wśród wyżej wymienionych podstawowych postulatów przewozowych możemy wyróżnić dodatkowe wymagania, takie jak: bezpośredniość, dostępność, pewność, punktualność. Postulaty te maja charakter uniwersalny, zarówno względem komunikacji zbiorowej, jak i indywidualnej27.

Transport w mieście jest uzależniony od wielu czynników. Udowodniono, iż poprawa jednego z czynników wpływa korzystnie na kolejny, a co za tym idzie, na cały system transportowy ${ }^{28}$. Szybko zmieniajacce i rozwijające się miasta wymagaja ciągłego przystosowywania transportu miejskiego, aby sprostać rosnącym oczekiwaniom mieszkańców.

${ }^{24}$ M. Szymczak, Logistyka miejska, s. 108.

${ }^{25}$ K. Hebel, M. Horoń, Popyt na usługi komunikacji miejskiej, [w:] O. Wyszomirski (red.), Gospodarowanie w komunikacji miejskiej, Wyd. Uniwersytetu Gdańskiego, Gdańsk 2002, s. 68.

${ }^{26}$ S. Dziadek, Systemy transportowe..., s. 110, za: B. Kontowicz, W. Suchorzewski, Komunikacja miejska. 39 Kongres Międzynarodowej Unii Transportu Publicznego, UITP, "Przegląd Informacyjny IGK" 1971, nr 3.

27 K. Hebel, M. Horoń, Popyt na usługi..., s. 68.

${ }^{28}$ B. Tundys, Logistyka miejska. Koncepcje, systemy, rozwiązania, Difin, Warszawa 2008, s. 125. 


\subsection{Koszty transportu miejskiego}

Transport jest jednym z zasadniczych czynników warunkujących rozwój gospodarczy. Wraz z rozwojem transportu miejskiego rośnie liczba problemów, z jakimi borykają się urbaniści. Trudności ekonomiki transportu miejskiego wiąża się z zagadnieniem kosztów i cen. Koszty to, według J. Twaróg, „rozchodowanie zasobów w określonym celu i określonej jednostce czasu, niezależnie od tego, czy znajduje ono odzwierciedlenie w danej chwili w faktycznych płatnościach, czy też nie"29.

W analizie należy uwzględnić nie tylko koszty przewoźników, ale również te generowane przez transport. Tworzą one razem koszty społeczne transportu. Wśród nich można wyróżnić30:

- koszty budowy oraz utrzymania infrastruktury,

- koszty czasu podróży,

- koszty eksploatacji środków przewozowych,

- koszty hałasu i zanieczyszczenia powietrza,

- koszty wypadków drogowych,

- inne.

Wśród kosztów budowy i utrzymania infrastruktury wyróżnia się koszty konstrukcji, terenu oraz degradacji środowiska spowodowane rozbudowa infrastruktury. Przy różnych rodzajach inwestycji koszty te mają inną wartość. Zakłada się, że przy rozbudowie infrastruktury naziemnej najwyższe są koszty degradacji środowiska. W przypadku kosztów terenu i degradacji środowiska szczególną uwagę poświęca się szerokiemu zakresowi, który wykracza poza koszty własne w przypadku wszystkich środków przewozowych. Problematyczne jest obliczenie tych kosztów. Przyjęto zatem, iż podstawowym założeniem powinny być korzyści, jakie infrastruktura może przynieść przy najbardziej ekonomicznym wykorzystaniu. Problematyka kosztów degradacji środowiska na skutek rozbudowy infrastruktury $z$ uwagi na trudności w obliczaniu jej kosztów jest bardzo często pomijana w analizach kosztów transportu miejskiego. Pewna część kosztów rozbudowy infrastruktury oraz jej utrzymania zalicza się do kosztów eksploatacji środków przewozowych.

Koszty eksploatacji środków przewozowych możemy podzielić na dwie kategorie: koszty posiadania samochodu oraz koszty jazdy. W ramach kosztów posiadania samochodu można wyodrębnić koszty:

29 J. Twaróg, Koszty logistyki przedsiębiorstw, Instytut Logistyki i Magazynowania, Poznań 2003, s. 16.

30 O. Wyszomirski, Transport miejski, s. 236-237. 
zakupu, ubezpieczenia, garażowania oraz utrzymania pojazdu. Dodatkowo, ze względu na ekonomiczne starzenie się samochodu, istnieje koszt pomniejszania się jego wartości. Natomiast same koszty jazdy zawierają w sobie koszy zużycia paliwa, olejów, naprawy i, podobnie jak w przypadku kosztów posiadania pojazdu, występuja tutaj także koszty związane z technicznym starzeniem się pojazdu oraz zmniejszeniem jego wartości.

Wycena kosztów czasu podróży jest dość złożona i nie została do tej pory jednoznacznie opisana w literaturze. Przedstawiono metody określania wartości czasu w transporcie, wyróżniając $m$. in. metodę produkcyjna, kosztowa, dochodowa oraz dochodowo-kosztową ${ }^{31}$.

Spośród wymienionych metod najczęściej stosowana jest metoda dochodowa. Zakłada ona, że czas przeznaczony na transport mógłby być wykorzystany na dodatkowa pracę i dlatego należy proporcjonalnie odnieść go do zarobków. Przyjmuje się, że poziom ten wynosi od $1 / 3$ do $2 / 3$ stawki zarobkowej ${ }^{32}$.

Kolejna grupa kosztów sa wartości hałasu oraz zanieczyszczenia powietrza. Rosnące zanieczyszczenie powietrza, wody i gleby jest w dużym stopniu spowodowane przez transport. Szczególnie wysoka emisja spalin oraz hałas występuje przy głównych arteriach miasta i odcinkach dróg stanowiących połączenie $z$ autostradami ${ }^{33}$. Koszty te wyliczane są na podstawie wydatków na stosowanie środków ochronnych przed danymi zagrożeniami. Zalicza się tutaj koszty: budowy ścian dźwiękochłonnych, wałów ochronnych, dźwiękoszczelnych konstrukcji okien z odpowiednim systemem wentylacji i koszty sadzenia drzew. Wydatki związane z zanieczyszczeniem powietrza są bardzo trudne do wycenienia. Jednym ze sposobów ich ustalenia moga być koszty poniesione na odnawianie elewacji budynków ${ }^{34}$.

Ostatnia kategorią kosztów transportu miejskiego są koszty wypadków drogowych. To straty związane z obrażeniami lub śmiercią osób. Dodatkowo moga to być również koszty zniszczeń środków transportu oraz spowodowanych wypadkami zakłóceń w ruchu. Wśród nich można wyróżnić koszty ${ }^{35}$ :

- bezpośrednie (uszkodzenie pojazdów, leczenie poszkodowanych),

${ }^{31}$ Tamże, s. 238, za: I. Tarski, Czynnik czasu w procesie transportowym, Wyd. Komunikacji i Łączności, Warszawa 1976.

32 O. Wyszomirski, Transport miejski, s. 283.

${ }_{33}$ B. Tundys, Logistyka miejska..., s. 132.

34 O. Wyszomirski, Transport miejski, s. 238.

35 Tamże, s. 239. 
- pośrednie (zmniejszenie dochodu narodowego wskutek śmierci obywateli),

- straty moralne.

Oprócz wyżej wymienionych kosztów transportu, definiowanych jako koszty społeczne, można wyróżnić jeszcze inne koszty odzwierciedlające wielopłaszczyznowy wpływ transportu na standard życia społeczeństwa miejskiego. Do tej kategorii można zaklasyfikować koszty związane z jakością transportu, mające wpływ na komfort jazdy, a co za tym idzie, na wydajność pracy. Niemniej jednak precyzyjne ustalenie poziomu takich kosztów jest bardzo trudne.

Przedstawiona analiza kosztów potwierdza tezę, iż koszty społeczne transportu miejskiego są złożone z wielu elementów o niejednorodnym stopniu wymierności. Muszą one podlegać systematycznym badaniom, aby mogły ilustrować stan realny. Przeprowadzone badania stanowia fundament dla późniejszej realizacji polityki transportowej.

\subsection{Infrastruktura transportu miejskiego ze szczególnym uwzględnieniem infrastruktury rowerowej}

W języku polskim pod pojęciem infrastruktury w ogólnym ujęciu określa się "ogół podstawowych urządzeń i instytucji koniecznych do prawidłowego funkcjonowania gospodarki"36. Urządzenia te obejmuja stworzone przez człowieka, trwale zlokalizowane, liniowe i punktowe obiekty użytku publicznego, stanowiące podbudowę życia społeczno-gospodarczego, z uwagi na ich funkcje przemieszczania osób i ładunków (transport), wiadomości (łączność), energii elektrycznej (energetyka) i wody (gospodarka wodna). Obiekty infrastrukturalne posiadaja cechy ${ }^{37}$, takie jak:

- niepodzielność techniczna i ekonomiczna,

- wysoka kapitałochłonność,

- długi okres żywotności oraz ewentualnie,

- długi okres powstawania,

- występowanie znacznych efektów zewnętrznych, z których wiele ma charakter odroczony.

Infrastruktura transportu miejskiego wchodzi w skład infrastruktury wielu gałęzi transportu. O infrastrukturze transportu mówimy zatem

${ }^{36}$ W. Kopaliński, Słownik wyrazów obcych i zwrotów obcojęzycznych, Wiedza Powszechna, Warszawa 1990, s. 229.

37 http://mfiles.pl/pl/index.php/Infrastruktura_transportowa [z dn. 1.11.2011]. 
wtedy, kiedy znajduje się ona na terenie obszaru zurbanizowanego. Jej elementami ${ }^{38}$ sa:

- drogi i ulice, z uwzględnieniem ich całego wyposażenia technicznego,

- torowiska,

- sieć energetyczna zasilająca metro, koleje, tramwaje,

- parkingi,

- dworce, przystanki oraz węzły przesiadkowe,

- zajezdnie autobusowe.

Podstawowymi, a zarazem najstarszymi elementami infrastruktury transportu miejskiego sa sieci ulic. Powstawały one wraz z rozwojem miast. W przypadku miast starszych maja one często charakter nieuporządkowany. Pojęcie drogi i ulicy nie jest tożsame i wymaga sprecyzowania.

Droga to „wydzielony pas terenu przeznaczony dla ruchu oraz postoju pojazdów i dla pieszych, wraz z placami, zatokami postojowymi, chodnikami, ścieżkami rowerowymi, zadrzewieniem i urządzeniami technicznymi związanymi z prowadzeniem i zabezpieczeniem ruchu, takimi jak: znaki drogowe, sygnalizacje świetlne i inne" ${ }^{\prime 39}$. Natomiast pod pojęciem ulicy rozumie się "drogę na terenie zabudowy miejskiej, łącznie z ewentualnie występującymi torami tramwajowymi. Stanowi ja cały teren pomiędzy liniami rozgraniczającymi, którymi są najczęściej na terenach zabudowanych granice nieruchomości przylegających do ulic" ${ }^{\prime 40}$. Z powyższych definicji wynika zatem, iż fundamentalnym elementem infrastruktury transportu kołowego miast sa ulice.

Podstawowym kryterium klasyfikacji dróg i ulic jest ich podział funkcjonalno-techniczny. Oznacza to, że rozróżnia się je w zależności od funkcji, a poszczególnym klasom odpowiadają rozwiązania technicz$n e^{41}$. Ulice $w$ miastach podzielone są na 5 kategorii ${ }^{42}$ :

- droga miejska ekspresowa (E),

- główna ulica ruchu przyspieszonego (GP),

38 O. Wyszomirski, Transport miejski, s. 214.

${ }^{39}$ Tamże, za: J. Podolski, Transport w miastach, Wyd. Komunikacji i Łączności, Warszawa 1985 , s. 74.

40 Tamże, s. 214.

${ }^{41} \mathrm{H}$. Karbowiak, Podstawy infrastruktury transportu, Wyd. Wyższej Szkoły Humanistyczno-Ekonomicznej, Łódź 2009, s. 106.

42 O. Wyszomirski, Transport miejski, s. 214, za: K. Zdanowicz, S. Monkiewicz, S. Sarna, Nowa klasyfikacja ulic w "Wytycznych projektowania ulic", "Transport Miejski" 1993, nr 1, s. 4. 
- ulica główna (G),

- ulica zbiorcza (Z),

- ulica lokalna (L),

- ulica dojazdowa (D).

Zasadniczy układ sieci ulic stanowią ulice klas S, GP, G, Z, podczas gdy ulice klas L i D są układem uzupełniającym ${ }^{43}$.

Miejskie drogi ekspresowe obsługuja jedynie ruch pojazdów samochodowych. Wyposażone sa $\mathrm{w}$ bezkolizyjne skrzyżowania. Stanowią element ogólnomiejskiego systemu drogowego oraz moga być przedłużeniem zamiejskiej drogi ekspresowej lub połaczeniem z autostrada ${ }^{44}$. Dostępne są tylko w węzłach i nie obsługuja bezpośredniego otoczenia. Ekspresowe drogi miejskie sa korzystne ekonomicznie jedynie przy dużym natężeniu ruchu. Moga być wykorzystywane przez komunikację autobusową o pospiesznym charakterze, przy uwzględnieniu ewentualnych przystanków poza trasą drogi ekspresowej.

Ulica główna ruchu przyspieszonego jest dedykowana dla wszystkich użytkowników. Ze względu na dużą uciążliwość ulica ta nie powinna przecinać terenów zamieszkanych oraz centrów miast. Chodnik należy odizolować od jezdni45.

Ulica główna jest zasadniczym elementem układu komunikacyjnego miasta, bez względu na jego wielkość. Może być połączeniem z droga lub jej kontynuacja. Stanowi filar układu komunikacyjnego miasta, ponieważ obsługuje centrum miasta i tereny mieszkalne ${ }^{46}$.

Ulica zbiorcza obsługuje zespoły dzielnic przemysłowych oraz terenów mieszkalnych ${ }^{47}$. Podobnie jak ulica główna, może być kontynuacja drogi.

Ulica lokalna obsługuje obszar, na którym jest zlokalizowana. Służy również dla wjazdów/wyjazdów oraz parkingów. Moga przez nie przebiegać linie autobusowe.

Ulica dojazdowa odpowiada wyłącznie za obsługę obiektów znajdujących się bezpośrednio przy niej ${ }^{48}$. W tab. 17 zostały zamieszczone wybrane charakterystyki omówionych typów ulic.

${ }^{43}$ H. Karbowiak, Podstawy infrastruktury..., s. 106.

${ }^{44}$ M. Matulewski, S. Konecka, P. Fajfer, A. Wojciechowski, Systemy logistyczne, s. 248.

${ }^{45}$ O. Wyszomirski, Transport miejski, s. 215.

46 Tamże, s. 216.

47 H. Karbowiak, Podstawy infrastruktury..., s. 107.

${ }^{48}$ M. Matulewski, S. Konecka, P. Fajfer, A. Wojciechowski, Systemy logistyczne, S. 248 . 
Tabela 17. Charakterystyka dróg

\begin{tabular}{|c|c|c|c|}
\hline $\begin{array}{l}\frac{7}{T} \\
\frac{\pi}{5} \\
\frac{5}{J}\end{array}$ & Klasa & Typowe funkcje & $\begin{array}{c}\text { Połączenie z innymi ulicami (a) } \\
\text { Obsługa bezpośredniego } \\
\text { otoczenia (b) }\end{array}$ \\
\hline \multirow{4}{*}{ 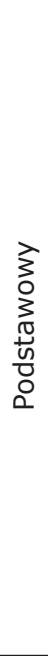 } & $\begin{array}{l}\text { S - droga } \\
\text { ekspresowa }\end{array}$ & $\begin{array}{l}\text { - powiązanie odległych rejonów } \\
\text { zespołów miast } \\
\text { - połaczenie układu dróg miej- } \\
\text { skich z drogami klasy A i S }\end{array}$ & $\begin{array}{l}\text { a) tylko w węzłach } \\
\text { b) nie obsługuje }\end{array}$ \\
\hline & $\begin{array}{l}\text { GP - ulica } \\
\text { główna ruchu } \\
\text { przyspieszo- } \\
\text { nego }\end{array}$ & $\begin{array}{l}\text { - połączenie odległych rejonów } \\
\text { dużego miasta (300 tys.) } \\
\text { - przedłużenie dróg GP, } \\
\text { połączenie dróg miejskich } \\
\text { z drogami klasy S i GP }\end{array}$ & $\begin{array}{l}\text { a) na skrzyżowaniach i węzłach } \\
\text { b) nie obsługuje }\end{array}$ \\
\hline & $\begin{array}{l}\text { G - ulica } \\
\text { główna }\end{array}$ & $\begin{array}{l}\text { - powiazanie rejonów miasta } \\
\text { dużego, średniego, małego } \\
\text { - połączenie układu dróg } \\
\text { miejskich z drogami klasy S } \\
\text { i GP }\end{array}$ & $\begin{array}{l}\text { a) na skrzyżowaniach } \\
\text { b) pasy postojowe, zjazdy(czę- } \\
\text { ściowo ograniczone) }\end{array}$ \\
\hline & $\begin{array}{l}\text { Z - ulica } \\
\text { zbiorcza }\end{array}$ & $\begin{array}{l}\text { - obsługa osiedli, zespołów } \\
\text { przemysłowych }\end{array}$ & $\begin{array}{l}\text { a) na skrzyżowaniach } \\
\text { b) nieograniczona }\end{array}$ \\
\hline \multirow{2}{*}{ 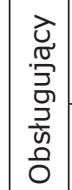 } & $\begin{array}{l}\text { L - ulica } \\
\text { lokalna }\end{array}$ & - obsługa osiedli & $\begin{array}{l}\text { a) na skrzyżowaniach } \\
\text { b) nieograniczona }\end{array}$ \\
\hline & $\begin{array}{l}\text { D - ulica } \\
\text { dojazdowa }\end{array}$ & $\begin{array}{l}\text { - obsługa zespołu budynków, } \\
\text { obiektów }\end{array}$ & $\begin{array}{l}\text { a) na skrzyżowaniach } \\
\text { b) nieograniczona }\end{array}$ \\
\hline
\end{tabular}

Źródło: opracowanie własne na podstawie: H. Karbowiak, Podstawy infrastruktury transportu, Wyd. Wyższej Szkoły Humanistyczno-Ekonomicznej, Łódź 2009, s. 107.

Elementy infrastruktury rowerowej posiadaja swoje specyfikacje prawne zawarte w ustawie o ruchu drogowym z 20 czerwca 1997 r. Prawo to jest dostosowane do wymogów Konwencji o Ruchu Drogowym, podpisanej w Wiedniu 8 listopada 1968 r. W 2009 r. znowelizowano ustawę o ruchu drogowym w celu poprawienia bezpieczeństwa ruchu drogowego, w tym również rowerzystów. Wprowadzone zmiany ujednolicaja zgodnie z Konwencja wiedeńską definicję drogi rowerowej oraz pasa rowerowego. Wpisano również nowe pojęcia, takie jak śluza rowerowa oraz zdefiniowano zasady korzystania z niej. Niektóre zmiany upraszczaja poruszanie się rowerem. Należy do nich dopuszczenie wyprzedzania przez rowerzystów prawą stroną pojazdów poruszających się wolno. Taką możliwość zakładaja przepisy ruchu w wielu państwach europejskich (m.in. w Holandii czy Danii). W większości krajów Wspólnoty 
Europejskiej w przepisach prawnych rower jest traktowany na równi $z$ innymi pojazdami ${ }^{49}$. Rozwiązania takie promuja rower jako przyjazny dla środowiska środek transportu, dając mu rzeczywistą i umocnioną prawnie przewagę nad samochodem w dużych miastach. Wdrożone zmiany pozwola na efektywniejsza organizację ruchu oraz poprawia bezpieczeństwo wszystkich uczestników ruchu.

Według art. 2 pkt 47 rower to „pojazd jednośladowy lub wielośladowy poruszany siła mięśni osoby jadącej tym pojazdem"50. Zazwyczaj maksymalna moc, jaką rowerzysta może osiagnną́ wynosi ok. $250 \mathrm{~W}$. Większość rowerzystów porusza się ze średnią prędkością 15-20 km/godz. ${ }^{51} \mathrm{~W}$ art. 2 pkt 5 pojęcia ścieżka, pas czy śluza rowerowa zostały zdefiniowane jako:

- "droga dla rowerów - droga lub jej część przeznaczona do ruchu rowerów, oznaczona odpowiednimi znakami drogowymi; droga dla rowerów jest oddzielona od innych dróg lub jezdni tej samej drogi konstrukcyjnie lub za pomoca urządzeń bezpieczeństwa ruchu drogowego,

- pas ruchu dla rowerów - część jezdni przeznaczona do ruchu rowerów w jednym kierunku, oznaczona odpowiednimi znakami drogowymi,

- śluza rowerowa - część jezdni na wlocie skrzyżowania na całej szerokości jezdni lub wybranego pasa ruchu przeznaczona do zatrzymania rowerów w celu zmiany kierunku jazdy lub ustapienia pierwszeństwa"52.

W Polsce w myśl uznawanego powszechnie holenderskiego podręcznika projektowania infrastruktury i organizowania ruchu rowerowego wyróżniono klasyfikację podziału tras rowerowych ${ }^{53}$ na:

- trasy główne - obsługuja ruch między dzielnicami,

- trasy zbiorcze i łącznikowe - łączą osiedla oraz inne ważne punkty z trasami głównymi,

- trasy lokalne (dojazdowe) - pozostałe.

W wielu krajach europejskich, gdzie ruch rowerowy stanowi znacząca część podróży, wyróżnia się następujące formy organizacji ruchu rowerowego ${ }^{54}$ :

- ruch mieszany - ruch rowerowy odbywa się po drodze/ulicy wraz z innymi użytkownikami jezdni,

${ }^{49}$ S. Gaca, W. Suchorzewski, M. Tracz, Inżynieria ruchu drogowego. Teoria i praktyka, Wyd. Komunikacji i Łączności, Warszawa 2008, s. 426.

${ }^{50}$ Ustawa z dn. 20 czerwca 1997 r. Prawo o ruchu drogowym, Dz.U. z 1997 r., nr 98, poz. 602.

${ }^{51}$ www.miastadlarowerow.pl/index_know_how.php [z dn. 1.11.2011].

52 Ustawa z dn. 20 czerwca 1997 r. Prawo o ruchu drogowym...

${ }^{53}$ S. Gaca, W. Suchorzewski, M. Tracz, Inżynieria ruchu drogowego..., s. 430.

${ }^{54}$ www.miastadlarowerow.pl/index_know_how.php [z dn. 1.11.2011]. 
- pas ruchu rowerowego - pas znajdujący się przy krawędzi jezdni wydzielony przy użyciu co najmniej znaków poziomych,

- pas ruchu rowerowego przyległy do jezdni - pas ruchu przylegający do jezdni, jednak podlegający wyróżnieniu, np. za pomocą zróżnicowania wysokości,

- ścieżka rowerowa - równoległa do jezdni, oddzielona od niej za pomoca np. pasa zieleni,

- wydzielona droga rowerowa - przeprowadzona niezależnie od dróg dla samochodów oraz ciągów pieszych.

Istotnym elementem $w$ upowszechnianiu jazdy rowerem jest przyznawanie rowerzystom przywilejów, polegających np. na wyłączeniu od przestrzegania nakazów bądź zakazów. Praktykuje się na ulicach jednokierunkowych możliwość poruszania się w obu kierunkach przez rowerzystów. W myśl art. 27 pkt 1 i 3:

"1. Kierujący pojazdem, zbliżając się do przejazdu dla rowerzystów, jest obowiązany zachować szczególna ostrożność i ustapić pierwszeństwa rowerowi znajdujacemu się na przejeździe. [...]

3. Kierujący pojazdem, przejeżdżając przez drogę dla rowerów poza jezdnia, jest obowiązany ustapić pierwszeństwa rowerowi"55.

Kodeks drogowy reguluje również oznakowanie elementów infrastruktury rowerowej.

Jednym z najważniejszych kryteriów wyboru optymalnych dla gospodarki kierunków i tempa rozwoju infrastruktury jest poznanie współzależności w procesach jej tworzenia oraz konsekwencji wynikających z przedsięwzięć inwestycyjnych ${ }^{56}$. Wprowadzone nowelizacje dotyczące prawa o ruchu drogowym będą oddziaływać na wszystkich uczestników ruchu drogowego oraz pomoga w organizacji i zarządzaniu ruchem. Służą one ujednoliceniu prawa polskiego z prawem obowiązującym w Unii Europejskiej.

\section{Podsumowanie}

W wyniku analiz przeprowadzonych w niniejszym rozdziale sformułowano następujące wnioski:

- Transport miejski pod względem technicznym nie jest wyodrębniany jako osobna gałą́ transportu.

55 Ustawa z dn. 20 czerwca 1997 r. Prawo o ruchu drogowym...

${ }^{56} \mathrm{~K}$. Wojewódzka-Król, Istota infrastruktury transportu, [w:] K. Wojewódzka-Król, R. Rolbiecki, Infrastruktura transportu, Wyd. Uniwersytetu Gdańskiego, Gdańsk 2008, S. 11 . 
- Określenie "transport miejski” nie jest do końca adekwatne, ponieważ obejmuje nie tylko miasto w jego granicach administracyjnych, lecz także bezpośrednio graniczące tereny podmiejskie.

- W transporcie miejskim wykorzystywane są środki transportu należące do różnych jego gałęzi. Środki przewozu w transporcie miejskim moga być sklasyfikowane pod względem technicznym (naziemne napędzane silnikami spalinowymi, naziemne napędzane energia elektryczna, naziemne kursujące po torowiskach i podziemne) oraz funkcjonalnym (indywidualne, zbiorowe, grupowe). Niektóre środki transportu należą do więcej niż jednej kategorii.

- Funkcjonowanie ośrodków zurbanizowanych wiąże się z koniecznościa umożliwienia mieszkańcom przemieszczania się bez względu na potrzebę przewozowa.

- Potrzeby przewozowe są związane ze społeczną aktywnością człowieka.

- Popyt na przewozy transportem miejskim odzwierciedla potrzeby przewozowe. Efektem zaspokojenia tego popytu są podróże komunikacyjne i przejazdy.

- Koszty społeczne transportu miejskiego są złożone z wielu elementów o niejednorodnym stopniu wymierności.

- Infrastruktura transportu miejskiego wchodzi w skład infrastruktury wielu gałęzi transportu. O infrastrukturze transportu mówimy zatem wtedy, gdy znajduje się ona na terenie obszaru zurbanizowanego.

- Kodeks drogowy reguluje oznakowanie elementów infrastruktury rowerowej. 


\section{Prospołeczne i proekologiczne rozwiązania transportu w Unii Europejskiej}

Magdalena Maciaszek*

\subsection{Polityka Unii Europejskiej w zakresie zrównoważonego transportu}

Transport jest jedna z kluczowych przyczyn rozwoju integracji krajów Starego Kontynentu. Pierwsze założenia znalazły odzwierciedlenie już w postanowieniach Traktatu Rzymskiego, na mocy którego została powołana w 1957 r. Europejska Wspólnota Gospodarcza. W późniejszym czasie Traktat z Maastricht ugruntował instytucjonalne, polityczne oraz budżetowe fundamenty polityki transportowej. W akcie została przyjęta wspólna polityka w zakresie transportu. Główne założenia polityki transportowej skupione są wokół obszarów, takich jak inwestycje infrastrukturalne, deregulacja rynku oraz jakość usług ${ }^{1}$. Dalszy rozwój transportu musi uwzględniać zagospodarowanie terenu, wpływ na środowisko oraz aktywności społeczne i gospodarcze². „Polityka transportowa jest jedna z form regulacji systemów transportowych. Stanowiąc o istocie i ramach formalno-prawnych nieautonomicznego, publicznego subsystemu regulacji, a jednocześnie będąc podstawową metodą i formą działania, jak też instrumentem wykonawczym tegoż subsytemu, polityka transportowa współokreśla zarazem charakter i strukturę typowego dla niego mechanizmu regulacyjnego"3. Dlatego też planowanie rozwoju polityki transportowej musi korespondować z innymi politykami sektorowymi. Takie działania nazywa się „planowaniem zintegrowanym”.

* Mgr Magdalena Maciaszek - Katedra Logistyki, Wydział Zarządzania Uniwersytetu Łódzkiego, ul. Matejki 22/26, 90-237 Łódź.

${ }^{1}$ Komisja Wspólnot Europejskich, Biała Księga. Europejska polityka transportowa 2010: Czas na podjęcie decyzji, Szczecin 2002, s. 140-141.

2 A. Koźlak, Kierunki zmian w planowaniu rozwoju transportu w miastach jako efekt dążenia do zrównoważonego rozwoju, "Transport Miejski i Regionalny” 2009, nr 7-8, s. 39.

${ }^{3}$ A. Grzelakowski, M. Matczak, A. Przybyłowski, Polityka transportowa Unii Europejskiej i jej implikacje dla systemów transportowych krajów członkowskich, Wyd. Akademii Morskiej w Gdyni, Gdynia 2008, s. 34. 
Problematykę i realizację wyżej wymienionych założeń regulują Białe Księgi, które skupiaja się na rozwoju zrównoważonego transportu w Europie. Definiowane są również narzędzia, przy pomocy których założenia będą realizowane.

Pojęcie zrównoważonego rozwoju zostało użyte po raz pierwszy 5 czerwca 1972 r. podczas konferencji w Sztokholmie dotyczącej środowiska człowieka. Przedstawiciele 113 krajów zaczęli kłaść większy nacisk na umiejętne dobieranie elementów rozwoju ekonomicznego, społecznego i ekologicznego4. Deklaracje, które zostały podpisane podczas tej konferencji, maja wpływ na kształtowanie celów polityki zrównoważonego transportu na całym świecie, w tym także wewnątrz Unii Europejskiej. W 1998 r. w Cardiff odbyła się konferencja Rady Europy, na której Rada ds. Transportu ogłosiła listę słabych punktów, wymagających podjęcia natychmiastowych działań. Wśród nich znalazły się: wzrost emisji $\mathrm{CO}_{2}$, emisja polutantów, wzrost kongestii w sektorze transportowym, podział międzygałęziowy oraz hałas w transporcie.

„W obszarze polityki transportowej UE dąży do zmiany struktury popytu poprzez przesunięcie popytu potencjalnego z sektora przewozów drogowych w kierunku transportu kolejowego, wodnego śródlądowego i morskiego oraz promowania transportu kombinowanego, a także zbiorowego transportu publicznego" ${ }^{\prime \prime}$. Wśród proponowanych przez Komisję Europejską rozwiązań znalazły się :

- liberalizacja, innowacje technologiczne, inwestycje infrastrukturalne, stworzenie bardziej konkurencyjnej sieci europejskiego transportu kolejowego,

- rozwój autostrad morskich i żeglugi oraz koordynacja inwestycji w portach,

- rozwój transportu intermodalnego,

- promocja inteligentnych systemów transportu,

- ustalenie poborów opłat za korzystanie z infrastruktury,

- plan rozwoju pojazdów ekologicznych,

- zainicjowanie działań udoskonalajacych transport miejski.

We wprowadzonych celach w ramach programu "Zrównoważony transport" podkreślane jest zaspokojenie przez systemy transportowe

${ }^{4}$ K. Kafel, W gąszczu definicji zrównoważonego transportu, Ministerstwo Edukacji Narodowej, za: www.ekoedu.uw.edu.pl/download/wyklady/2007/KKafel.doc [z dn. 4.11.2011].

${ }^{5}$ A. Przybyłowski, Polityka spójności i polityka transportowa Unii Europejskiej w kontekście zrównoważonego rozwoju, "Transport i Komunikacja” 2009, nr 5, s. 35.

${ }^{6}$ Tamże. 
potrzeb ekonomicznych, społecznych oraz środowiskowych, przy jednoczesnym zminimalizowaniu negatywnego wpływu na środowisko.

Komisja Transportu i Turystyki Parlamentu Europejskiego opublikowała w roku 2009 raport dotyczący planu działania w zakresie mobilności miejskiej. Parlament Europejski będzie dażył do zwiększenia tempa badań i innowacji w zakresie mobilności ${ }^{7}$. W tym celu dane dotyczące mobilności zostaną zweryfikowane oraz będa uwzględniać bardziej szczegółowe informacje, dotyczące: ruchu ulicznego, zanieczyszczenia powietrza i hałasu, wskaźników jakościowych usług transportowych. Sugerowane jest również uruchomienie europejskiego forum, gdzie będzie możliwa wymiana informacji dotyczących dobrych praktyk i innowacyjnych osiagnięć. Proponowanym kolejnym krokiem jest wzmocnienie programu badań nad rozwojem inteligentnych systemów transportowych. Kluczowym wyzwaniem jest zachęcenie do optymalizowania alternatywnych sposobów przemieszczania się. Zachęca się do zainicjowania planów zintegrowanego, zrównoważonego transportu w aglomeracjach miejskich.

Problematycznym aspektem jest finansowanie podejmowanych inicjatyw. Parlament Europejski wyraża możliwość stworzenia europejskiego instrumentu finansowania w latach 2014-2020, który umożliwiłby współfinansowanie części inwestycji w środki transportu przyjazne środowisku i społeczeństwu. Unia Europejska dąży również do wyeliminowania różnic pomiędzy wielkością opłat za wjazd do centrum miasta. Dąży się do tego, aby opłaty były odgórnymi wytycznymi obowiązującymi na terenie Unii Europejskiej. Kolejnym zaleceniem jest stworzenie "karty użytkownika" transportu miejskiego. Obejmowałaby ona pieszych oraz rowerzystów i definiowałaby podział jezdni. Dzięki takim rozwiązaniom wyeliminowałoby to obecne nierówności między użytkownikami jezdni. Komisja zachęca także do podtrzymywania i rozszerzania inicjatyw w ramach Europejskiego Dnia bez Samochodu. Tutaj podkreśla się rolę władz lokalnych w prowadzeniu polityki przyjaznej środowisku.

Od czasu wejścia w życie Traktatu Rzymskiego polityka transportowa jest jedna z głównych dziedzin z zakresu kompetencji wspólnotowych. Transport miejski jest bardzo ważnym elementem transportu towarów i osób na terenie Unii, ponieważ aż 80\% Europejczyków będzie w roku 2020 zamieszkiwać tereny miejskie. W 2007 r. w wyniku ro-

${ }^{7}$ Rezolucja parlamentu europejskiego na rzecz mobilności w miastach, "Transport Miejski i Regionalny" 2009, nr 4, s. 37. 
snących oczekiwań inicjatywy w zakresie polityki transportu miejskiego stały się priorytetowe ${ }^{8}$.

Unia Europejska jest odpowiedzialna za opracowanie zintegrowanego podejścia, gromadzenie i rozpowszechnianie rzetelnych informacji.

\subsection{Inicjatywy Unii Europejskiej w zakresie rozwoju zrównoważonego transportu}

Zdecydowana większość ludności Unii Europejskiej zamieszkuje w środowisku miejskim: ponad 60\% mieszka w miastach powyżej 10 tys. mieszkańców ${ }^{9}$. "Rozszerzanie się struktur miejskich, zmiany w stylu życia i elastyczność prywatnego samochodu połączone z nie zawsze odpowiednim funkcjonowaniem transportu publicznego spowodowały w ciagu ostatnich 40 lat ogromny zalew ruchu w miastach"10. Wzmożony ruch i zatłoczenie miast wywołuja zanieczyszczenie powietrza i hałas. Wyzwaniem dla Unii Europejskiej od wielu już lat jest zwiększenie mobilności przy jednoczesnym zmniejszeniu kongestii, liczby wypadków oraz zanieczyszczenia powietrza. Komisja Europejska pracuje nad polepszaniem standardu życia mieszkańców poprzez promowanie zrównoważonego transportu. Skuteczny i dobrze zorganizowany transport miejski może istotnie przyczynić się do osiągnięcia założonych przez Unię celów.

Komisja Europejska po raz pierwszy w 1995 r. podjęła działania na rzecz mobilności, wprowadzając projekt "Citizens Network". Zainicjował on szereg inicjatyw opartych na "najlepszych praktykach". W roku 2007 w następstwie utworzonej w 2001 r. Białej Księgi Transportu, Komisja Europejska wprowadziła Zieloną Księgę „W kierunku nowej kultury mobilności w mieście"11. Dokument ten zapoczątkował debatę na temat kluczowych zagadnień mobilności w miastach. Skupiono się na 5 aspektach ${ }^{12}$ :

- zielone miasta,

8 Tamże, s. 36.

${ }^{9}$ http://ec.europa.eu/transport/urban/urban_mobility/urban_mobility_en.htm [z dn. 4.11.2011].

${ }^{10}$ Komisja Wspólnot Europejskich, Biała Księga..., s. 7.

${ }^{11}$ http://ec.europa.eu/transport/urban/urban_mobility/urban_mobility_en.htm [z dn. 4.11.2011].

${ }^{12}$ Dyrektoriat Generalny Departamentu Energii i Transportu, Green Paper. Towards a new culture for urban mobility, 2007, s. 2-3. 
- usprawnienie ruchu,

- inteligentny transport miejski,

- dostępność transportu miejskiego dla wszystkich mieszkańców,

- bezpieczeństwo transportu miejskiego.

Na tej podstawie 30 września 2009 r. Komisja Europejska wyznaczyła plan działania. Zaproponowano 20 sposobów pomocy władzom lokalnym, regionalnym oraz krajowym w zakresie realizacji celów na rzecz zrównoważonej mobilności. Wskazane narzędzia ułatwią tworzenie polityk miast, regionów czy też krajów w zakresie mobilności. Na rok 2012 Komisja Europejska zaplanowała przegląd realizacji planów i weryfikację dalszych działań.

Unia Europejska podejmuje szereg przedsięwzięć mających na celu promowanie zrównoważonego rozwoju. Wśród takich projektów są: inicjatywa CIVITAS, Europejski Tydzień Zrównoważonego Transportu (European Mobility Week), czy też Europejski Dzień bez Samochodu.

Europejski Tydzień Zrównoważonego Transportu (European Mobility Week) to największa inicjatywa ogólnoeuropejska, mająca na celu wzrost świadomości mieszkańców oraz promowanie przyjaznych miastu środków transportu. Celem jest również zachęcenie władz europejskich miast do inwestowania w niezbędną infrastrukturę. Corocznie od $2002 \mathrm{r}$. kampania przypada na dni 16-22 września. Z roku na rok przystępuje do niej coraz to więcej miast. W roku 2009 udział w kampanii wzięło udział 1500 miast Europy ${ }^{13}$.

Przedsięwzięcie to zachęca do alternatywnych rozwiązań w zakresie transportu. Założeniem kampanii jest ponadto promowanie świadomości społecznej w zakresie potrzeby działania przeciw zanieczyszczeniom środowiska spowodowanym wzrostem ruchu samochodowego w aglomeracjach miejskich. W rzeczywistości to nie tylko walka z zanieczyszczeniem powietrza i hałasem, ale także chęć poprawy jakości i stylu życia w mieście. Kampania składa się z trzech elementów ${ }^{14}$ :

- zachęcenia do korzystania z innych środków transportu niż samochody osobowe,

- podniesienia świadomości mieszkańców na temat negatywnych skutków dla stylu życia,

- pokazania miasta bardziej przyjaznego mieszkańcom.

Podczas tego tygodnia miasta mają szansę zaprezentowania całej Europie, jak bardzo troszczą się o aspekty środowiskowe. Działania

${ }^{13}$ www.euractiv.pl/gospodarka/artykul/europejski-tydzie-zrownowaonego-transpor tu-001260 [z dn. 6.11.2011].

${ }^{14}$ www.mi.gov.pl/2-48203f1e24e2f-1791272-p_1.htm [z dn. 6.11.2011]. 
te daja również szansę obywatelom na zamanifestowanie wobec nich swojego poparcia i zaangażowanie się na rzecz poprawy środowiska miasta. Każdego roku kampania organizowana jest pod innym hasłem. W 2009 r. było to: "Popraw klimat swojego miasta”. W 2012 r. Tydzień Mobilności odbył się pod hasłem: „Podróżuj inteligentniej, żyj lepiej".

Ogromny wzrost natężenia ruchu samochodowego w ostatnich latach wywołał intensywna reakcję społeczeństwa na konsekwencje, jakie ten wzrost niesie: hałas, zanieczyszczenie powietrza, kongestia, co pośrednio wpływa na zdrowie obywateli. Coraz częściej mieszkańcy zapadaja na choroby układu oddechowego czy krążeniowego i są w coraz większym stopniu narażeni na działanie stresu.

$Z$ drugiej strony, badania naukowe dowodza, że regularna aktywność stanowi klucz do zdrowia. $Z$ tego powodu kampania 2012 r. w dużej mierze skupia się na pokazaniu mieszkańcom, jaki wpływ na ich zdrowie maja wybierane przez nich środki transportu. Przedsięwzięcie Europejskiego Tygodnia Zrównoważonego Transportu promuje jazdę na rowerze i jej istotna rolę w codziennej aktywności fizycznej. W roku 2012 miasta skupią się na rozwiązywaniu problemu braku aktywności fizycznej wśród mieszkańców. Ponadto zdrowie i zrównoważony transport powinny być kojarzone jako kombinacja, która wyraźnie przyczynia się do zmniejszenia zanieczyszczenia powietrza, kongestii, liczby wypadków oraz sprzyja wygospodarowaniu większej przestrzeni do życia aniżeli do jazdy samochodem.

Komitet Europejskiego Tygodnia Zrównoważonego Transportu nagradza działania prowadzone przez władze lokalne w ramach tej kampanii. Nagroda przyznawana jest miastu, które w największym stopniu udowodniło, że kwestia zrównoważonego rozwoju transportu miejskiego i ochrony środowiska jest dla niego priorytetem. Sposoby działań nagrodzonych miast nosza tytuł "dobrych praktyk". W roku 2000 zwycięzca zostało szwedzkie miasto Gävle.

Kulminacją Tygodnia Zrównoważonego Transportu, która przypada na 22 września, jest Europejski Dzień bez Samochodu. Celem tego dnia jest popularyzacja transportu miejskiego przyjaznego środowisku. W ramach tego przedsięwzięcia wiele ulic zostaje zamkniętych dla ruchu samochodowego. W zamian zwiększa się liczbę połączeń komunikacji zbiorowej, zapewniając darmowe przejazdy. Dodatkowo można 
za darmo wypożyczyć rower. Policjanci i służby miejskie zachęcaja w tym dniu do korzystania z komunikacji publicznej albo wybrania roweru ${ }^{15}$.

Dokonuje się również pomiaru efektów w postaci: wielkości zmniejszenia ruchu, poprawy jakości powietrza, zmniejszenia poziomu hałasu oraz oceny opinii społecznej. Ma to na celu zebranie danych na temat takiego przedsięwzięcia w skali lokalnej, narodowej oraz europejskiej ${ }^{16}$.

Kolejnym działaniem podejmowanym przez Unię Europejską jest inicjatywa CIVITAS. Działania tego programu sa ukierunkowane na tworzenie lepszych i bardziej przyjaznych systemów transportu miejskiego. Nazwa pochodzi od pierwszych liter słów: CIty (ang. miasto), VITAlity (ang. witalność), Sustainability (ang. stabilność) ${ }^{17}$. Dzięki tej inicjatywie Komisja Europejska dąży do dokonania przełomu we wdrażaniu stabilnych i zintegrowanych strategii transportu miejskiego. Inicjatywa składa się z dwóch etapów. Pierwszy, CIVITAS I, został zainaugurowany w 2002 r. Etap ten trwał 4 lata i było weń zaangażowanych 19 miast. Kolejny etap, CIVITAS II, obejmował lata 2005-2009 i 17 miast. Trzeci etap, CIVITAS PLUS, obejmuje lata 2008-2012. W tym projekcie bierze udział rekordowa liczba miast, bo aż 25.

Każda inicjatywa podzielona jest na grupy projektowe, w skład których wchodzi kilka miast. W projekcie CIVITAS PLUS możemy wyróżnić 5 grup projektowych ${ }^{18}$ :

- ARCHIMEDES: Aalborg, Brighton, San Sebastian, Iasi, Monza, Usti-nad-Laben,

- MIMOSA: Bolonia, Funchal, Utrecht, Gdańsk, Talin,

- RENAISSANCE: Perugia, Bath, Gorna-Oryahovitsa, Szczecinek, Skopje,

- ELAN: Ljubljana, Gent, Zagrzeb, Porto, Brno,

- MODERN: Kraków, Brescia, Coimbra, Vitoria-Gasteiz.

Komisja Europejska przeznaczyła fundusz w wysokości $100 \mathrm{mln}$ euro na inicjatywę CIVITAS $^{19}$. Cele jakie zostały postawione przez Komisję Europejską to²0:

- promowanie i wdrażanie czystych oraz wydajnych środków transportu miejskiego,

15 www.mos.gov.pl/artykul/2729_materialy_dla_mediow/9809_popraw_klimat _swojego_miasta.html [z dn. 6.11.2011].

${ }^{16}$ T. Kopata, Dlaczego Europejski Dzień bez Samochodu?, Polski Klub Ekologiczny, Wrocław 2001, s. 15.

17 www.civitas-initiative.org/cms_pages.phtml?id=348\&lan $=p l$ [z dn. 10.11.2011].

${ }_{18}$ www.civitas-initiative.org/main.phtml?lan=en [z dn. 10.11.2011].

${ }^{19}$ www.civitas-initiative.org/cms_pages.phtml?id=348\&lan $=p l$ [z dn. 10.11.2011].

${ }^{20}$ CIVITAS, Promoting Sustainable Urban Mobility with CIVITAS, 2010, za: www.civitas-initiative.org/downloadcenter.phtml?top $=76 \&$ s_topic $=80 \&$ rows $=2$ [z dn. 10.11.2011] . 
- wdrażanie nowoczesnych technologii w dziedzinie transportu,

- stworzenie rynków dla rozwoju innowacji.

W ramach realizacji założonych celów miasta opracowuja programy demonstracyjne $w$ grupach projektowych. Do wzięcia udziału w inicjatywnie może zgłosić się każde miasto europejskie. Miasta powinny wykazać swoja chęć i zaangażowanie we wdrażanie ulepszonych, przyjaznych środowisku rozwiązań w transporcie miejskim. Następnie przedstawiciel lokalnych władz musi podpisać deklarację czynnego uczestnictwa w projekcie. Oznacza to m.in. obecność na zjazdach CIVITAS Forum oraz aktywne promowanie inicjatywy na szczeblu lokalnym i regionalnym. Każde miasto, które zadeklarowało chęć podjęcia wyzwania tego projektu, staje się zarazem członkiem platformy CIVITAS Forum. Niemniej jednak zarejestrować się na forum może każde miasto, nie tylko to biorace udział $w$ danym etapie programu. Platforma ta umożliwia wymianę doświadczeń i pomysłów między członkami projektów. Członkowie CIVITAS Forum moga brać udział w cyklicznych zjazdach umożliwiających dyskusję nad przebiegiem wdrażania inicjatywy. Miasto z najlepszymi wynikami zostaje nagrodzone.

Wszystkie inicjatywy przeprowadzane są w różnych miastach europejskich od wielu lat. Według badań, programy te maja dużą efektywność i cieszą się uznaniem. Zapoczątkowane działania przekładaja się na dalszą politykę miast.

\subsection{Prospołeczne i proekologiczne korzyści płynące z wykorzystania roweru}

Prawidłowo funkcjonujacy ruch i system transportowy jest bardzo istotny dla miasta. Mieszkańcy miast, w których udział rowerów w całkowitym transporcie jest wysoki, przekonały się, jak wiele zalet niesie za sobą ich wykorzystanie. Zalety te obejmuja różne obszary ${ }^{21}$ :

- ekologiczne,

- polityczne,

- społeczne,

- ekonomiczne.

Bez wattpienia rower jest najbardziej przyjaznym środowisku środkiem transportu. Jego negatywny wpływ na środowisko jest zerowy.

${ }^{21}$ J. Dekoster, U. Schollaert, Miasta rowerowe miastami przyszłości, Komisja Europejska, Luksemburg 2000, s. 15. 
Jazda na rowerze nie przyczynia się do wydzielania spalin ani nie powoduje hałasu. Co więcej, aby móc korzystać z roweru, nie jest potrzebne wykorzystanie energii pochodzącej ze źródeł nieodnawialnych, tylko praca mięśni rowerzysty.

$Z$ drugiej strony, wpływ ruchu samochodowego na środowisko jest wciąż ogromny. "Krótkie i częste przejazdy dokonywane na zimnym silniku zwiększają zużycie paliwa, a emisje moga być trzy lub cztery razy wyższe, gdy prędkość ruchu jest trzy lub cztery razy mniejsza. W związku z tym transport miejski powoduje $40 \%$ emisji $\mathrm{CO}_{2}$ odpowiedzialnej za zmiany klimatyczne, jak również innych polutantów, które maja niepokojacy wpływ na zdrowie mieszkańców miast"22.

Dlatego promowanie jazdy na rowerze może pomóc $w$ walce $z$ rosnącą liczbą samochodów w miastach. W 2009 r. Unia Europejska wyznaczyła cel, aby $15 \%$ podróży w miastach wykonywanych było za pomoca roweru. Oznaczałoby to potrojenie obecnego udziału ${ }^{23}$. Osiagnięcie takiego celu pozwoliłoby na zmniejszenie o $5 \%$ emisji $\mathrm{CO}_{2}$ pochodzącego z transportu24. Organicznie zużycia źródeł energii nieodnawialnych mogłoby również pozwolić na energetyczne uniezależnienie się od państw, które są liderami w ich wydobyciu ${ }^{25}$.

Mieszkańcy miast powyżej 250 tys. są codziennie narażeni na hałas o wartości przekraczajacej $70 \mathrm{~dB}^{26}$. Hałas, definiowany jako niekorzystne dla zdrowia głośne dźwięki, podobnie jak zanieczyszczenie powietrza ma negatywny wpływ na zdrowie człowieka. Już sam transport drogowy to natężenie dźwięku w granicach $75 \mathrm{~dB}$ dla samochodów i $95 \mathrm{~dB}$ dla autobusów ${ }^{27}$. Hałas może prowadzić do bezsenności, nadmiernego stresu, problemów z nadciśnieniem, a nawet chorób psychicznych. Rower, jako środek transportu niewywołujący hałasu, mógłby stać się doskonałym rozwiązaniem w walce o zdrowie mieszkańców Europy.

Kolejnym aspektem środowiskowym związanym z wykorzystaniem roweru jest zagospodarowywanie przestrzeni na potrzeby infrastruktury. Transport samochodowy wymaga adaptowania coraz to większych

22 Tamże.

${ }^{23}$ European Cyclist Federation, A sustainable future for transport: Towards and integrated, technology-led and user friendly system, 2009, s. 4.

${ }^{24}$ European Cyclist Federation, Transport Energy Efficiency: Response to the public consultation on the Action Plan for Energy Efficiency, 2007, za: www.ecf.com/3644_1 [z dn. 10.11.2011].

25 J. Dekoster, U. Schollaert, Miasta rowerowe..., s. 15.

26 http://dom.money.pl/budownictwo/wiadomosci/artykul/halas;w;wielkim;miescie,249,0,417529.html [z dn. 10.11.2011].

27 Tamże. 
przestrzeni miejskich. W konsekwencji pod budowę dróg wycinane są lasy, a przestrzeń miejska mogąca służyć do rekreacji zostaje zastąpiona parkingami. Dla przykładu, na miejscu parkingowym dla jednego samochodu może zmieścić się ok. 10 rowerów. Standardowy pas ruchu może pomieścić $w$ ciągu godziny 2 tys. samochodów, podczas gdy w tym samym czasie zmieści się tam 14 tys. rowerów ${ }^{28}$. Większe wykorzystanie roweru pozwoliłoby na zmniejszenie natężenia ruchu w miastach, a także zwiększenie atrakcyjności centrum miasta.

Mieszkańcy maja prawo do mobilności i dostępności. Oba te czynniki są bardzo ważne dla prawidłowo funkcjonującego miasta, zarówno pod względem społecznym, jak i ekonomicznym. Dostępność może być w tym przypadku rozumiana jako możliwość dotarcia z łatwością i bezpiecznie do danego miejsca. Samochód, dopóki nie zaczął być związany z kongestią oraz dużą liczbą wypadków, był postrzegany jako spełnienie obu tych wymagań. Nadmierne wykorzystanie samochodów doprowadziło do zatłoczenia na drogach i poziom mobilności znacznie się ograniczył. Międzynarodowe rankingi pokazuja, że miasta przyjazne rowerzystom, gdzie udział roweru w całkowitym transporcie przekracza średnia europejską, są miastami również wysoko notowanymi pod względem jakości życia. Przekonanie mieszkańców, iż za pomocą roweru mogą oni dotrzeć bezpiecznie i szybko praktycznie w każde miejsce, jest obecnie dużym wyzwaniem dla Unii Europejskiej29.

Aktywność fizyczna stanowi klucz do zdrowia zarówno fizycznego, jak i mentalnego. Światowa Organizacja Zdrowia zaleca co najmniej 30 min ruchu codziennie ${ }^{30}$. Zgodnie z badaniami WHO, $30 \mathrm{~min}$ codziennej aktywności może zredukować o 50\% ryzyko zachorowania na choroby układu krążenia. Jazda na rowerze jest doskonałym sposobem włączenia ruchu do codziennych zajęć. Podczas jazdy na rowerze wykorzystywane są rytmicznie wszystkie mięśnie ciała; okresy ich aktywnej pracy występuja na przemian z okresami odpoczynku. Energia wykorzystywana podczas jazdy na rowerze w warunkach miejskich wynosi ok. $60 \% \mathrm{VO}_{2} \max ^{31}$ (zdolność pochłaniania tlenu przez organizm). $\mathrm{VO}_{2}$ max to jeden z najpopularniejszych wskaźników wydolności fizycznej, szczególnie wydolności tlenowej. Określa również

${ }^{28}$ European Cyclist Federation, A sustainable future for transport..., s. 4.

29 Tamże, s. 5.

${ }^{30}$ C. Dora, M. Phillips, Transport, environment and health, WHO Regional Publications, European Series no. 89, Copenhagen 2000, s. 31.

${ }^{31}$ N. Cavill, A. Davis, Cycling and health: what's the evidence?, Cycling England, London 2007, s. 25. 
intensywność wysiłku². Taki poziom jest wystarczający do osiągnięcia korzyści zdrowotnych w krótkim czasie. Jazda na rowerze pomaga również kontrolować wagę - przeciętnie podczas minuty jazdy spalanych jest 5 kilokalorii 33 .

Główna zaleta jazdy na rowerze jest fakt, że można wysiłek fizyczny włączyć do codziennych czynności, takich jak dojazd do pracy lub szkoły. Zatem nie wymaga poświęcenia dodatkowego czasu na aktywność fizyczną. Co więcej, jazda na rowerze nie wymaga specjalnych predyspozycji - z powodzeniem może być wykonywana przez większość społeczeństwa.

Korzyści płynace z wykorzystania roweru nie kończą się na poprawieniu zdrowia jednostki, ale rozciagają się na korzyści dla zdrowia publicznego poprzez zmniejszenie negatywnych skutków związanych $z$ ruchem samochodowym.

Transport nakłada wysokie koszy zarówno na jednostki, jak i na całe społeczeństwo bezpośrednio (budowa dróg i ich utrzymanie) oraz pośrednio (wypadki, zanieczyszczenie powietrza, kongestia) ${ }^{34}$. Zmniejszenie poziomu indywidualnego wykorzystania transportu samochodowego przy jednoczesnym zastapieniu go transportem rowerowym może prowadzić do redukcji całkowitych kosztów transportu ${ }^{35}$.

Duże oszczędności może przynieść obniżenie wydatków na budowę i utrzymanie dróg dla ruchu samochodowego na rzecz inwestycji w wysokiej jakości infrastrukturę rowerowa, która jest znacznie mniej kosztowna.

Zmniejszenie zatłoczenia w centrum, lepsze wykorzystanie przestrzeni oraz wzrost wykorzystania roweru może umożliwić rozwój biznesu. Dzięki wzrostowi zapotrzebowania na rowery przemysł rowerowy może zacząć się rozwijać. Zwiększy się zapotrzebowanie na produkcję i serwisy. W tych zakładach znalazłoby zatrudnienie wielu ludzi.

Rower oprócz tego, że stanowi najbardziej przyjazny środowisku środek transportu, jest również najtańszy w eksploatacji. Cena jego zakupu jest wielokrotnie niższa niż cena samochodu. Również utrzymanie nie jest tak kosztowne w porównaniu z wydatkami związanymi z samochodem. Jazda rowerem nie wymaga dodatkowych opłat, jak w przypadku transportu miejskiego. Parkingi rowerowe są w większości bezpłatne, a opłaty za korzystanie z "roweru miejskiego" niskie. Dodatkowo, regularna jazda na rowerze ma udokumentowany pozytywny wpływ na zdrowie, co pozwoli na zmniejszenie wydatków na ochronę

\footnotetext{
32 http://pl.wikipedia.org/wiki/Pu\%C5\%82ap_tlenowy [z dn. 10.11.2011].

${ }^{33}$ N. Cavill, A. Davis, Cycling and health..., s. 29.

${ }^{34}$ European Cyclist Federation, A sustainable future for transport..., s. 4.

35 Tamże, s. 5.
} 
zdrowia ${ }^{36}$. Wieloletnie badania przeprowadzane w miastach europejskich ukazuja różnorodne korzyści, jakie niesie ze sobą wykorzystanie roweru jako środka transportu.

\subsection{Multimodalne rozwiązania w transporcie miejskim}

Poprzez pojęcie "multimodalnego transportu" rozumiany jest zintegrowany przewóz przy użyciu przynajmniej dwóch środków transportu, z uwzględnieniem realizacji zadań podporządkowanych potrzebom procesu całej podróży miejskiej. Odrębne gałęzie transportu przestają być w przewozie multimodalnym autonomiczne, a stają się kolejnymi sposobami przemieszczania sięz7.

Każda podróż w mieście składa się z łańcucha elementarnych przemieszczeń, wykonywanych pieszo oraz z wykorzystaniem środków transportowych. Taka sekwencja nazywana jest łańcuchem przemieszczeń ${ }^{38}$.

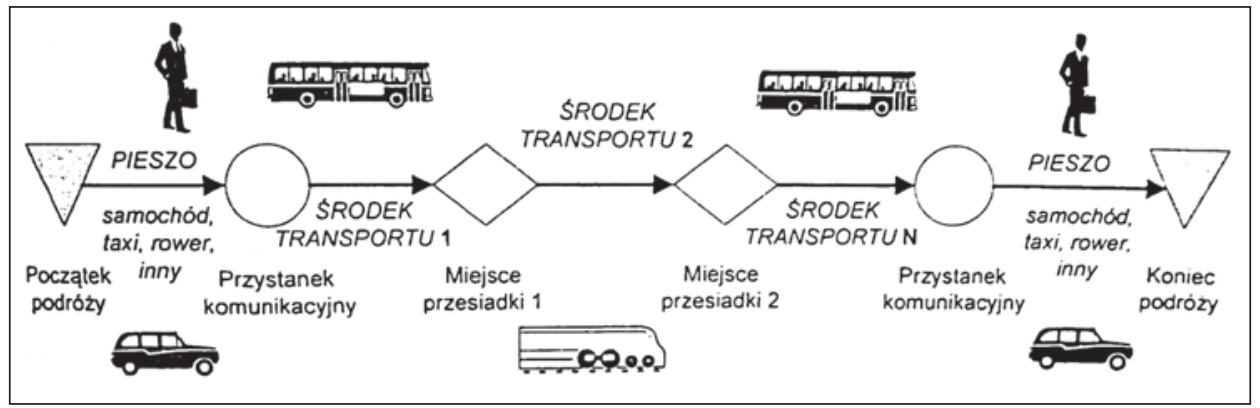

Rysunek 15. Podróż miejska jako łańcuch przemieszczania

Źródło: J. Szołtysek, Podstawy logistyki miejskiej, Wyd. Akademii Ekonomicznej w Katowicach, Katowice 2009, s. 61

Planowanie podróży $w$ kategoriach multimodalnych doprowadziło do zaproponowania uniwersalnych rozwiązań. Znajdują się wśród nich ${ }^{39}$ :

- Park \& Ride,

- Bike \& Ride,

- Kiss \& Ride,

${ }^{36}$ J. Dekoster, U. Schollaert, Miasta rowerowe..., s. 15.

37 J. Szołtysek, Podstawy logistyki miejskiej, Wyd. Akademii Ekonomicznej w Katowicach, Katowice 2009, s. 85.

38 Tamże, s. 61.

39 Tamże, s. 86. 
- Car-pooling,

- Car-sharing,

Główną idea programu Park \& Ride jest zachęcanie społeczeństwa do ograniczenia wykorzystania prywatnego samochodu podczas podróży w mieście. Zakłada ona dojazd własnym środkiem transportu, pozostawienie go na korzystnych warunkach na parkingu poza centrum miasta i kontynuowanie podróży środkami komunikacji zbiorowej. Założeniem systemu ${ }^{40}$ jest, po pierwsze, zwiększenie atrakcyjności transportu publicznego i indywidualnego (rowery, podróże odbywane piechota), a po drugie, zmniejszenie atrakcyjności wykorzystania samochodu. Aby spełnić te założenia, niezbędna jest odpowiednia infrastruktura. Systemy parkingowe powinny być dostosowane do potrzeb podróżnych. Dodatkowo władze miasta powinny ograniczyć dostępność parkingową w centrum oraz kontrolować opłaty za wjazd do strefy opłat.

Obok systemu Park \& Ride rozwinał się system umożliwiający podróż łączoną rowerem i innym środkiem transportu publicznego, określaną terminem Bike \& Ride $^{41}$. Założeniem tego systemu jest dojazd rowerem do stacji najbliższej stacji kolejowej lub przystanku, a następnie kontynuowanie podróży środkiem komunikacji publicznej. Dzięki takiemu systemowi zwiększa się zasięg oddziaływania środków komunikacji miejskiej. Na dworcach rozmieszczone sa specjalnie przystosowane parkingi dla rowerów, umożliwiające bezpieczne i niedrogie przechowanie roweru. Innym sposobem jest umożliwienie zabrania roweru do środków transportu miejskiego i przetransportowanie ich do kolejnego punktu podróży. Celem jest odciążenie centrów miast od wzmożonego ruchu komunikacji zbiorowej ${ }^{42}$. W codziennych podróżach rower może być również wykorzystany w systemach, takich jak: B\&T/BUS (Bike \& Train/BUS). System ten zakłada dojazd rowerem do dworca kolejowego lub przystanku autobusowego i kontynuowanie podróży już innym środkiem transportu ${ }^{43}$.

Następnym rozwiązaniem jest system nazwany Kiss \& Ride. Celem tego programu jest zmniejszenie negatywnych efektów spowodowanych kongestią w miastach oraz wzrost bezpieczeństwa w obrębie

${ }^{40}$ www.zm.org.pl/?a=park_and_ride-083 [z dn. 13.11.2011].

${ }^{41} \mathrm{~J}$. Wesołowski, Miasto w ruchu. Dobre praktyki w organizowaniu transportu miejskiego, Instytut Spraw Obywatelskich, Łódź 2008, s. 143.

${ }^{42}$ O. Pietrzak, Logistyka miejska jako narzędzie optymalizujące obsługę ruchu pasażerskiego, "Transport i Komunikacja” 2010, nr 1, s. 37.

${ }^{43}$ A. Zalewski, Europejskie tendencje użytkowania roweru na początku XXI w., materiały konferencyjne VII Konferencji Naukowo-Technicznej „Skuteczne zmniejszanie zatłoczenia miast", Uni-Druk, Poznań 2009, s. 221. 
placówek oświatowych. Program skierowany jest do rodziców dowożących swoje dzieci do szkół. Rodzice, aby pozostawić swoje dziecko jak najbliżej szkoły, często wjeżdżają do stref, gdzie obowiązuje zakaz ruchu. Oprócz łamania przepisów, utrudniają ruch. Dlatego założeniem tej inicjatywy jest zapewnienie bezpiecznej multimodalnej drogi dziecka do szkoły. Władze miast wskazują przystanki, gdzie dyżuruja pracownicy szkół i rodzice. Z tych przystanków dzieci są odwożone specjalnym autobusem. Przejazdy obywają się regularnie dzięki wyznaczeniu specjalnego pasa dla takich autobusów. Dzieci są bezpiecznie dowożone na czas do szkoły, a ruch w mieście przestaje być utrudniony ${ }^{44}$. Wydzielane są również specjalne miejsca postojowe z ograniczonym czasem zatrzymania ${ }^{45}$.

Car-pooling jest natomiast formą podróżowania, która polega na udostępnianiu w prywatnym samochodzie miejsc dla innych podróżujących. Podróżni ustalają między sobą podział kosztów. Początki carpoolingu sięgają lat 50. XX wieku. W Polsce w czasach PRL prowadzono kampanię „podwieź sąsiada"46.

Główną korzyścią płynącą z wykorzystanie car-poolingu jest oszczędność kosztów przejazdu, a także większy komfort podróży w porównaniu $z$ transportem zbiorowym. Dzięki wydzielonym pasom czas podróży jest znacznie krótszy. Firmy, których pracownicy korzystaja z car-poolingu, moga zoptymalizować wykorzystanie parkingów zakładowych.

Organizacja car-poolingu jest możliwa indywidualnie - ze znajomymi z pracy czy też sąsiadami, lub też przy użyciu specjalnego serwisu internetowego. Przykładem takiego portalu jest www.carpooling.pl.

Użytkownicy na internetowych platformach moga zadeklarować wolne miejsce w swoim samochodzie na danej trasie, a także je wyszukać. Po umówieniu szczegółów, kierowca odbiera towarzyszy podróży w wyznaczonym miejscu, a następnie wspólnie odbywaja podróż w docelowe miejsce, którym może być tylko punkt przejazdu kierowcy na trasie (np. przystanek, dworzec) lub cel całej podróży.

Kolejnym przykładem rozwiązań sprzyjających zrównoważonemu transportowi jest Car-sharing. Idea ta została niezależnie stworzona w Niemczech i w Szwajcarii już w 1987 r. ${ }^{47}$ Car-sharing opiera się

44 J. Szołtysek, Podstawy logistyki..., s. 87.

${ }^{45}$ O. Pietrzak, Logistyka miejska jako narzędzie..., s. 37.

${ }^{46}$ J. Szołtysek, Car-pooling w koncepcji podróży pasażerskiej w miastach, "Logistyka" 2008, nr 4, s. 45-48.

47 B. Tundys, Logistyka miejska. Koncepcje, systemy, rozwiązania, Difin, Warszawa 2008, s. 196. 
na możliwości wypożyczenia samochodu nawet tylko na jedną godzinę. Samochody włączone do programu sa specjalnie oznakowane i napędzane ekologicznym paliwem. Dodatkowo miejsca parkingowe sa zlokalizowane w punktach węzłowych transportu (np. na dworcach kolejowych $)^{48}$. Posiadanie karty kolejowej zazwyczaj upoważnia do zniżek przy wypożyczaniu auta w innym mieście. Samochód z powodzeniem można zarezerwować za pomocą Internetu lub telefonicznie. Wydatek użytkownika to niewielka kaucja oraz koszty paliwa. Takie rozwiązanie pozwala na zmniejszenie kongestii w miastach i zachęcenie mieszkańców do wykorzystywania wypożyczonego samochodu na krótkich trasach dojazdowych.

\section{Podsumowanie}

W wyniku analiz przeprowadzonych w niniejszym rozdziale można sformułować następujące wnioski:

- Transport jest jedną z kluczowych przyczyn rozwoju integracji krajów Europy, dlatego też Unia Europejska kładzie duży nacisk na zrównoważony rozwój transportu.

- W ramach polityki transportowej Unia Europejska prowadzi wiele programów majacych na celu promocję zrównoważonego transportu, m.in. Europejski Dzień bez Samochodu, Tydzień Zrównoważonego Rozwoju oraz inicjatywę CIVITAS.

- Wśród narzędzi pozwalających na zintegrowane podróże można wskazać różne rodzaje podróży multimodalnych: Park \& Ride, Bike \& Ride, Car-pooling.

- Rower jest najbardziej przyjaznym środowisku środkiem transportu. Zalety płynące z wykorzystania roweru obejmuja aspekty ekonomiczne, społeczne, polityczne oraz środowiskowe.

- Niezwiększenie wykorzystania środków transportowych sprzyjajacych zrównoważonemu rozwojowi może stać się dużym zagrożeniem dla Europejczyków.

48 Tamże. 



\section{0. „Miasta rowerowe" miastami przyszłości}

Magdalena Maciaszek*

\subsection{Rower jako efektywny środek transportu na przykładzie Kopenhagi}

Miasto jest odzwierciedleniem społeczeństwa. Zawiera w sobie jego nadzieje, radości i smutki. Ludzie próbuja planować miasta i nimi zarządzać. Miasto spełnia wiele funkcji, m.in. miejsca zamieszkania, pracy, rozrywki. Coraz więcej osób przeprowadza się z mniejszych miejscowości do większych miast, co powoduje zwiększony ruch. Ludzie korzystają z różnych środków transportu, aby sprawnie poruszać się po zatłoczonych miastach.

Kopenhaga nie jest w tym przypadku inna niż pozostałe miasta europejskie. Wyróżnia ją przede wszystkim ponadprzeciętne wykorzystanie jednego z najstarszych środków transportu - roweru.

W pierwszej połowie XIX wieku rowery zaczęły być coraz bardziej popularne w Danii, mimo iż były drogie i luksusowe. Na rower mogły pozwolić sobie jedynie wyższe klasy społeczne. Wielkość miasta oraz płaski teren sprzyjały wykorzystaniu rowerów. Szacuje się, że już w 1890 r. w Kopenhadze było ok. 3 tys. rowerów ${ }^{1}$. Kiedy rozpoczęto masowa produkcję, cena roweru spadła, co spowodowało jeszcze większy wzrost ich popularności wśród mieszkańców Kopenhagi. Pomiędzy rokiem 1890 a 1900 liczba rowerzystów wzrosła aż do 30 tys. ${ }^{2} \mathrm{Na}$ tak szybki rozwój tego środka transportu miała wpływ Duńska Federacja Rowerzystów, która powstała w 1905 r. Jest to najstarsza organizacja rowerzystów w Europie, a jej głównym celem jest wpływanie na władze,

* Mgr Magdalena Maciaszek - Katedra Logistyki, Wydział Zarządzania Uniwersytetu Łódzkiego, ul. Matejki 22/26, 90-237 Łódź.

${ }^{1}$ M. Santos Canals, A. Pinaud, T. Janneau, O. R. Rasmussen (red.), Copenhagen: How bicycles can become an efficient means of public transportation, Roskilde University, Roskilde 2006, s. 10.

${ }^{2}$ www.cycling-embassy.dk/cycling-history [z dn. 13.11.2011]. 
aby tworzyły infrastrukturę przyjazną rowerzystom. Już w roku 1912 Kopenhaga posiadała $50 \mathrm{~km}$ ścieżek rowerowych ${ }^{3}$.

W latach 30. XX wieku rowery zdominowały ulice duńskiej stolicy. Większość miejsc publicznego użytku była tak rozplanowana, aby możliwe było dotarcie do nich rowerem. W tym samym czasie weekendowe wycieczki rowerowe poza miasto stały się niezmiernie popularnym sposobem spędzania wolnego czasu.

Podczas II wojny światowej rower stał się koniecznością. Okupacja niemiecka spowodowała ograniczenia w dostawie paliwa, co doprowadziło do konieczności zastapienia samochodu rowerem.

Po wojnie rozpoczął się proces masowej emigracji mieszkańców Kopenhagi. Populacja miasta w latach $1950-1980$ spadła z 770 tys. do 500 tys., ale za to liczba Duńczyków posiadających samochody zaczęła powoli rosnąć. Niemniej jednak pierwszy kryzys energetyczny w 1973 r. uświadomił Duńczykom wady wykorzystywania samochodów jako środka transportu. Wywołało to w 1970 r. masowe demonstracje w celu poprawienia warunków dla rowerzystów. Manifestacje te nie pozostały bez echa. W latach 90. zanotowano 50\% wzrost ruchu rowerowego. Od roku 1981 każdy budżet Danii zawiera fundusze na ciagłe doskonalenie infrastruktury rowerowej4.

Już od ponad stu lat ulice Kopenhagi sa wypełnione rowerami. W historii było wiele wzlotów i upadków. Jednak tradycja rowerowa przetrwała i obecne problemy, związane z energetyką czy zanieczyszczeniem powietrza, przekonuja, że miasta takie jak Kopenhaga maja przed sobą świetlana przyszłość.

Obecnie w Danii 19\% wszystkich podróży odbywa się przy użyciu roweru $^{5}$. Jest to drugi wynik w Europie. Średnia trasa, jaka Duńczycy pokonuja codziennie na rowerze wynosi $3 \mathrm{~km}^{6} .55 \%$ mieszkańców Kopenhagi korzysta z roweru, dojeżdżając każdego dnia do pracy lub szkoły. Według ankiety przeprowadzonej wśród mieszkańców Kopenhagi głównym powodem, dla którego mieszkańcy duńskiej stolicy przesiadają się na rower, jest szybkość i łatwość przemieszczania się7. Oczywiście, istnieja czynniki sprawiające, że połowa mieszkańców miasta wybiera rower.

Rowerzyści w Kopenhadze są przyjmowani za pewnik. Większość z nich będzie dalej korzystać z roweru tak długo, jak tylko zapewniona

${ }^{3}$ M. Santos Canals, A. Pinaud, T. Janneau, O. R. Rasmussen (red.), Copenhagen: How bicycles can become..., s. 10.

4 Tamże, s. 11.

${ }^{5}$ www.cycling-embassy.dk/statistics [z dn. 13.11.2011].

${ }^{6}$ Tamże.

7 Tamże. 
będzie wysoka jakość transportu rowerowego. Jakość jest najważniejszym czynnikiem decydującym o liczbie mieszkańców wykorzystujących rower do codziennej komunikacji. Czynnikami wpływającymi na wysoką jakość są: poczucie bezpieczeństwa oraz samo bezpieczeństwo, prędkość poruszania się, komfort i zdrowie.

Poczucie bezpieczeństwa jest subiektywnym postrzeganiem przez rowerzystę zagrożeń wynikających z jazdy na rowerze. To postrzeganie może być oparte na wcześniejszych doświadczeniach albo na chwilowym, subiektywnym odczuciu potencjalnego zagrożenia. W ostatnim czasie poczucie bezpieczeństwa wśród rowerzystów Kopenhagi nieznacznie spadło. Według badań przeprowadzonych w 2008 r. wśród mieszkańców duńskiej stolicy, ponad połowa deklaruje poczucie bezpieczeństwa ${ }^{8}$. Głównym zagrożeniem, według rowerzystów, jest ruch samochodowy. Władze miasta wysoko cenią bezpieczeństwo swoich mieszkańców i dlatego wiele inicjatyw ukierunkowuje na jego ciągłe podnoszenie. Jednym z przykładów jest zainstalowanie na jezdni świateł LED w miejscu, gdzie ścieżka rowerowa przecina jezdnię. Kiedy rowerzysta znajduje się na ścieżce, światła zaczynają migać. Sa one widoczne jedynie w lusterkach bocznych samochodu. Rowerzysta nie widzi migających świateł. Ma to na celu nierozpraszanie jego uwagi. System ten pozwolił na zredukowanie rocznej liczby wypadków na jednym z najbardziej niebezpiecznych skrzyżowań w Danii - z 15 do $1^{9}$.

Drugim czynnikiem wpływającym na jakość transportu jest bezpieczeństwo. Jest to statystyczne ujęcie liczby wypadków. W latach 2004-2006 spadła ona ze 124 do 92. Liczba śmiertelnych wypadków na przestrzeni tych dwóch lat wyniosła $6^{10}$. Przykład Kopenhagi pokazuje, że jest możliwe ciągłe zmniejszanie takich statystyk. Niemniej jednak optymistyczne statystyki nie maja przełożenia na poczucie bezpieczeństwa wśród mieszkańców. Zmniejszająca się liczba wypadków nie powoduje wzrostu poczucia bezpieczeństwa.

Duża motywacja dla mieszkańców Kopenhagi jest konkurencyjność szybkości przemieszczania się rowerem w stosunku do transportu samochodowego. Średnia prędkość, z jaką porusza się rowerzysta

${ }^{8}$ City of Copenhagen, Buildings and Construction Administration Roads and Parks Department, Cycle Policy 2002-2012, 2002, s. 10.

${ }^{9}$ Film: Bicycle Culture 2.0 in Copenhagen: Look at This Amazing Bike-Friendly Urban Planning, zamieszczony na: www.treehugger.com/files/2009/12/streetfilms-copenhagencop15-bicycles-bikes-video.php [z dn. 13.11.2011].

${ }^{10}$ City of Copenhagen, The Technical and Environmental Administration Traffic Department, Bicycle Account, 2008, s. 7. 
w Kopenhadze wynosi $16 \mathrm{~km} / \mathrm{h}^{11}$. Ciągłe prace nad ulepszaniem ścieżek rowerowych oraz synchronizacja świateł będą umożliwiać zwiększenie prędkości poruszania się. W celu upłynnienia ruchu zastosowano np. takie rozwiązanie, gdzie zielone światło dla rowerzystów zapala się kilka sekund wcześniej niż dla samochodów. Stopniowo wprowadzany jest też system "zielonych ścieżek rowerowych", który ma na celu zminimalizowanie konieczności zatrzymywania się rowerzystów. Sygnalizacja świetlna znajdująca się na "zielonej" trasie jest ze sobą zsynchronizowana i jeśli rowerzysta jedzie z prędkościa $20 \mathrm{~km} / \mathrm{h}$, to na odcinku 6 kilometrów nie będzie musiał się zatrzymać ani razu' ${ }^{12}$.

Wśród Duńczyków panuje wysoka świadomość społeczna. Dobroczynny wpływ, jaki na zdrowie ma jazda na rowerze, jest również ważnym czynnikiem determinującym decyzję o poruszaniu się rowerem. W 2004 r. duńskie Ministerstwo Zdrowia przeprowadziło badania obrazujące związek pomiędzy rowerem jako środkiem transportu, zdrowiem a finansami. Z badań wynika, iż np. 10\% wzrost liczby przejechanych dziennie kilometrów pozwoli zaoszczędzić opiece zdrowotnej $59 \mathrm{mln}$ koron rocznie ${ }^{13}$.

Komfort to ostatni czynnik wpływający na postrzeganie jakości transportu rowerowego przez mieszkańców Kopenhagi. Co dwa lata władze miasta kontaktują się z ponad tysiącem mieszkańców, pytając ich, czy są zadowoleni z działań prowadzonych przez miasto na rzecz rowerzystów.

Jeśli chodzi o politykę transportową Kopenhagi, wszystkie podejmowane inicjatywy są efektem długoterminowego planowania poprzedzonego badaniami. Zarówno w budżecie, jak i w strategii miasta jest zawsze miejsce dla polityki rowerowej. Duński rząd nieustannie dąży do ograniczenia ryzyka i stopnia obrażeń ponoszonych w wyniku wypadków rowerowych oraz zapewnienia komfortowych warunków jazdy ${ }^{14}$. Aby to osiagnąć, konieczne jest ciągłe prowadzenie kampanii promujących "rowerowy styl życia”. Ich głównym założeniem jest oczywiście sprawienie, aby mieszkańcy coraz chętniej i częściej wybierali rower. Władze miasta skupiają się przede wszystkim na takich aspektach, jak:

${ }^{11}$ www.kk.dk/sitecore/content/Subsites/CityOfCopenhagen/SubsiteFrontpage/ InformationAndServices/CityAndTraffic/CityOfCyclists/CycleStatistics.aspx [z dn. 1.03.2010].

${ }^{12}$ City of Copenhagen, The Technical and Environmental Administration Traffic Department, Bicycle Account, s. 13.

${ }^{13}$ City of Copenhagen, Buildings and Construction Administration Roads and Parks Department, Cycle Policy..., s. 18.

${ }^{14}$ R. Rakowera, A. Kaleniewicz, Rower na co dzień: komunikacja, rekreacja, ochrona środowiska, Stowarzyszenie „Sekcja Rowerzystów Miejskich", Poznań 2001, s. 7. 
- infrastruktura rowerowa,

- poprawa warunków jazdy w centrum miasta,

- intermodalność roweru,

- miejsca parkingowe,

- odpowiednia konserwacja już istniejących ścieżek,

- oczyszczanie ścieżek rowerowych,

- wzrost świadomości społecznej"15.

Ścieżki rowerowe są głównym elementem infrastruktury rowerowej. W Kopenhadze obecnie istnieje ok. $350 \mathrm{~km}$ ścieżek rowerowych ${ }^{16}$. Podróżując po duńskiej stolicy, zawsze znajdzie się miejsce, gdzie jest aktualnie budowany kolejny odcinek albo inny poddawany jest konserwacji.

Tradycyjna ścieżka jest jednokierunkowa, ma co najmniej dwa metry szerokości i biegnie pomiędzy chodnikiem a jezdnia, od których jest oddzielona krawężnikami. Elementy te znajduja się na różnych poziomach (najwyżej chodnik, niżej ścieżka, a najniżej jezdnia). Takie rozwiązanie zapewnia rowerzystom bezpieczeństwo i komfort jazdy. Kiedy ścieżka przecina skrzyżowanie, krawężniki znikaja, natomiast kolor nawierzchni ścieżki zmienia się na niebieski, sygnalizując kierowcom, że muszą ustapić pierwszeństwa jadącym po niej rowerzystom. Ilość kolizji zmniejsza się, a poczucie bezpieczeństwa rowerzystów wzrasta ${ }^{17}$.

Ponieważ w Kopenhadze jest więcej rowerów niż mieszkańców, fundamentalnym problemem sa miejsca parkingowe.

Tabela 18. Propozycja ilości miejsc rowerowych przypadających na każdą nową inwestycję

\begin{tabular}{|l|l|}
\hline Miejsce zamieszkania & 2,5 miejsca rowerowego na $100 \mathrm{~m}^{2}$ terenów mieszkalnych \\
\hline Miejsce pracy & 1,5 miejsca rowerowego na $100 \mathrm{~m}^{2}$ przestrzeni biurowej \\
\hline Sklep & $\begin{array}{l}3 \text { miejsca rowerowe na } 100 \mathrm{~m}^{2} \text { sklepu }+0,5 \text { miejsca rowerowe- } \\
\text { go na pracownika }\end{array}$ \\
\hline
\end{tabular}

Źródło: opracowanie własne na podstawie Bike Account 2008.

Parkingi rowerowe znajduja sie we wszystkich ważnych punktach miasta: przy sklepach, domach, szkołach, dworcach. Na ogół nie ma problemu

${ }^{15}$ City of Copenhagen, Buildings and Construction Administration Roads and Parks Department, Cycle Policy..., s. 21.

${ }^{16}$ www.kk.dk/sitecore/content/Subsites/CityOfCopenhagen/SubsiteFrontpage/ InformationAndServices/CityAndTraffic/CityOfCyclists/CycleStatistics.aspx [z dn. 10.03.2010].

${ }^{17}$ www.zm.org.pl/?a=kopenhaga-polityka [z dn. 16.11.2011]. 
ze znalezieniem miejsca do zaparkowania roweru, jednak władze miasta uważaja, że liczba parkingów i stojaków rowerowych jest wciąż niewystarczająca. Władze miasta, Duńskie Koleje Państwowe oraz Transport Kopenhagi (przewoźnik miejski) wspólnie finansują i pracują nad zwiększeniem liczby miejsc parkingowych przy stacjach kolejowych oraz przystankach autobusowych.

Największe parkingi są usytuowane przy stacjach kolei miejskiej, co umożliwia transport intermodalny. W pociągach znajdują się specjalne wagony przystosowane do transportu roweru. Co więcej, taksówki są również przygotowane do przewożenia roweru i mają obowiązek zabrać rower klienta.

Jakość dróg jest regularnie monitorowana. Od niedawna do tego celu stosuje się rower ze specjalnymi czujnikami, które automatycznie mierza gładkość nawierzchni. Na mapie oznacza się ścieżki, które wymagaja szybkiej naprawy; ścieżki o zadawalającej jakości, które będą wymagały naprawy później oraz ścieżki w bardzo dobrym stanie. Rocznie miasto wydaje około $9 \mathrm{mln}$ koron $(4,5 \mathrm{mln} z \nmid)$ na utrzymanie i naprawę ścieżek rowerowych ${ }^{18}$.

Cele długoterminowe zawarte w polityce rowerowej Kopenhagi zakładaja, że do roku $2015^{19}$ :

- liczba osób dojeżdżajacych do pracy na rowerze wzrośnie do 50\%,

- liczba wypadków z udziałem rowerzystów spadnie o połowę,

- wzrośnie do 80\% liczba rowerzystów czujących się bezpiecznie,

- prędkość podróżowania na większe dystanse zostanie zwiększona o $10 \%$,

- poprawi się komfort jazdy - liczba ścieżek rowerowych o niezadowalającej jakości nie będzie przekraczać 5\%,

- wprowadzi się nowy system roweru miejskiego.

Takie dane widnieja w materiałach miejskiego planu na rzecz środowiska, zatytułowanego „Eko-Metropolia. Nasza Wizja 2015”, który wraz z pozostałymi inicjatywami działa na rzecz uczynienia z Kopenhagi w 2015 r. miasta najbardziej przyjaznego rowerzystom. Nie bez znaczenia jest również fakt, iż na te cele przeznaczane są wysokie fundusze - ponad 150 mln duńskich koron przewidziano na wydatki na parkingi rowerowe, zielone ścieżki, trasy oraz poprawę bezpieczeństwa ${ }^{20}$.

18 Tamże.

19 www.kk.dk/sitecore/content/Subsites/CityOfCopenhagen/SubsiteFrontpage/ InformationAndServices/CityAndTraffic/CityOfCyclists/Background.aspx [z dn. 02.03.2010].

${ }^{20}$ www.visitdenmark.no/polen/pl-pl/menu/turist/nyheder/nyheder/rowery-kopen haga.htm\#SubHeader1 [z dn. 16.11.2011]. 
Obecnie istniejący system rowerów udostępnianych publicznie nazywa się "ByCyklen” (duń. rower miejski) i istnieje od roku 1995, aczkolwiek już w roku 1989 powstała pierwsza inicjatywa roweru miejskiego w Kopenhadze. Morten Sadolin i Ole Wessung zaproponowali mieszkańcom Kopenhagi poruszanie się publicznymi rowerami, aby zapobiec rosnącej liczbie kradzieży. Podstawowym założeniem inicjatywy "Rower Miejski" było posiadanie publicznej floty rowerów, których wypożyczenie jest możliwe za monetowa kaucja. Finansowanie zapewniały wypływy z reklam, które nie były wystarczajace do utrzymania i konserwacji całej floty. Dlatego w 1991 r. zaprzestano korzystania z rowerów miejskich. Dopiero w roku 1995 została powołana fundacja Fonden Bycyklen i København, której zadaniem było przywrócenie do życia projektu roweru miejskiego. Władze miasta przekazały firmie pełna odpowiedzialność wraz z przestrzenia potrzebna do wstawienia stojaków. Projekt "Roweru Miejskiego" jest finansowany przez sponsorów, którzy w zamian moga zamieścić swoja reklamę na rowerach i stojakach. Rok później, kiedy Kopenhaga była Europejską Stolicą Kultury, rower miejski zyskał dużą popularność. Mimo iż projekt ten nie oddziałuje już z taką samą siła, jak 15 lat temu i jest bardziej popularny wśród turystów, to wciąż jest wizytówką Kopenhagi.

Obsługa roweru miejskiego jest bardzo prosta. Wystarczy znaleźć jedną ze 110 stacji rowerowych znajdujących się w centrum, następnie wrzucić depozyt w wysokości 20 koron duńskich. Wypożyczony rower można używać w określonej strefie bez ograniczeń czasowych. Nie jest konieczne zwracanie roweru $w$ to samo miejsce, $z$ którego został wypożyczony. Rowery miejskie są specjalnie przystosowane. Posiadaja bardziej wytrzymałe opony, a siedzenie może być dostosowane do indywidualnych potrzeb rowerzysty. Jednak nie maja dodatkowych urzadzeń, takich jak licznik, lampka, koszyk, aby wyeliminować kradzieże. Również nie jest możliwe zabezpieczenie roweru przy pomocy własnego zamka.

Kopenhaga zyskała popularność wśród polityków na całym świecie dzięki innowacyjnym pomysłom $w$ rozwiązywaniu problemów dużego miasta, takich jak zanieczyszczenie powietrza, kongestia czy nadwaga mieszkańców. Ścieżki rowerowe w Nowym Jorku noszą nazwę "kopenhaskich". W grudniu 2009 r. duńska stolica przyciągnęła uwagę całego świata, organizując szczyt klimatyczny. To nie przypadek, że wybrano właśnie Kopenhagę - miasto, które stało się liderem na wielu ekologicznych obszarach. Dlatego głównym celem, do którego dąży teraz duńska stolica, jest zyskanie miana Eko-Metropolii Świata do 2015 r. 


\subsection{Odense - duńskie narodowe miasto rowerzystów}

Odense jest trzecim co do wielkości miastem Danii (187929 mieszkańców) $)^{21}$. Minister transportu nadał Odense miano Narodowego Miasta Rowerów, ponieważ z powodzeniem od wielu lat promuje jazdę na rowerze.

Odense wprowadziło czteroletni program z budżetem 3,5 mln euro, mający na celu zachęcenie mieszkańców do zastąpienia samochodu rowerem, poprawienie bezpieczeństwa oraz danie pierwszeństwa rowerom nad samochodami. Pomiędzy 1999 a 2002 r. przeprowadzono ponad 60 programów demonstracyjnych ${ }^{22}$. W ciagu tych dwóch lat liczba przejazdów rowerowych wzrosła o 50\%, a liczba wypadków spadła o $20 \%{ }^{23}$. Cele, jakie miasto Odense sobie wyznaczyło, to:

- wzrost liczby podróży rowerowych o 35\% do roku 2020,

- umożliwienie rowerzystom zwiększenia prędkości poruszania się o 10\%,

- poprawienie jakości ścieżek rowerowych,

- wprowadzenie systemu roweru miejskiego,

- wzrost poczucia bezpieczeństwa rowerzystów ${ }^{24}$.

W ostatnich latach w Odense miało miejsce wiele kampanii promujacych rowerowy styl życia, o charakterze zarówno zabawowym, jak i prospołecznym. Ponieważ w Danii dzieci bardzo szybko zaczynaja jeździć na rowerze, kampanie dotyczyły głównie dzieci i zachęcały do dojazdu do przedszkola czy szkoły na rowerze. W rezultacie zaangażowani zostali zarówno rodzice, jak i placówki oświaty. Miasto Odense zapewniało darmowe wózki umożliwiające transport małego dziecka na rowerze.

W przedsięwzięciach promujących rower szczególną uwagę poświęcono jakości. Stworzono ponad 2 tys. miejsc parkingowych ${ }^{25}$. Każde rozwiązanie charakteryzuje się pięknem, estetyką, a zwłaszcza funkcjonalnością. Na dworcu centralnym w Odense powstał podziemny parking dla rowerów z kamerami, muzyka, specjalnymi blokadami, fontanna, schowkami i szafkami na wyposażenie rowerów ${ }^{26}$.

Jakość oznacza również utrzymanie czystych ścieżek rowerowych. Stan ścieżek rowerowych jest regularnie sprawdzany przez "rowerową grupę raportująca". Grupa ta, wyposażona w kamery cyfrowe i telefony

${ }^{21}$ www.odense.dk/web/english/facts\%20and\%20figures.aspx [z dn. 16.11.2011].

${ }^{22}$ European Cyclist Federation, Odense - The National Cycle City of Denmark, Bicycle Research Report no. 157, 2004.

23 Tamże.

${ }^{24}$ www.odense.dk/web4/cyklisternesby/vision\%20og\%20maal.aspx [zdn. 16.11.2011].

${ }^{25}$ European Cyclist Federation, Odense - The National Cycle City...

${ }^{26}$ R. Rakowera, A. Kaleniewicz, Rower na co dzień..., s. 10. 
komórkowe, monitoruje miasto i raportuje zauważone problemy do wydziałów komunalnych ${ }^{27}$.

Skutecznie przeprowadzone kampanie w Odense zapoczatkowały wiele zmian w innych duńskich miastach. Odense jest pionierem wielu rozwiązań.

\subsection{Rozwiązania transportu rowerowego w Holandii}

Holandia i rower stały się prawie synonimami. Od wielu lat Holandia jest kojarzona nie tylko z tulipanami, ale również z dużą liczbą rowerów na ulicach. Jest ona na pierwszym miejscu w Europie pod względem wykorzystania roweru jako środka transportu ${ }^{28}$. Rozwiazania tam stosowane stanowia wzór do naśladowania dla innych krajów. Holandia, podobnie jak Dania, jest krajem, gdzie liczba rowerów przewyższa liczbę mieszkańców. Przeciętny Holender posiada 1,11 roweru²9. Duża liczba rowerów sprzyja, niestety, wzmożonej ich kradzieży. Szacuje się, że każdego roku kradzionych jest 750 tys. rowerów. Tylko 45\% kradzieży jest zgłaszanych na policję. Odsetek rowerów odnalezionych i zwróconych właścicielom jest znikomy ${ }^{30}$.
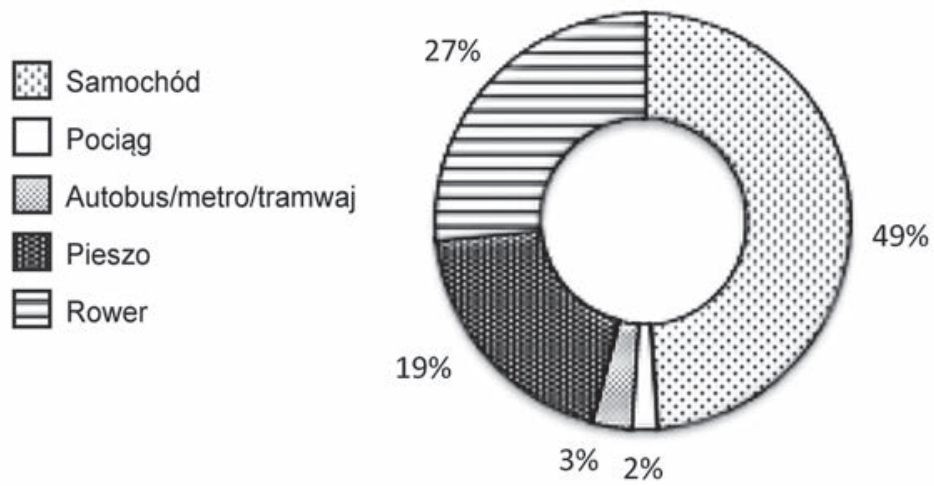

Wykres 1. Udział poszczególnych środków transportu w Holandii

Źródło: opracowanie własne na podstawie: Ministerie van Verkeer en Waterstaat, Cycling in the Netherlands, 2009, za: http://www.fietsberaad.nl/library/repository/ bestanden/CyclingintheNetherlands2009.pdf [z dn. 16.10.2012]

27 Tamże.

28 http://ec.europa.eu/transport/road_safety/specialist/knowledge/pedestrians/ pedestrians_and_cylists_unprotected_road_users/walking_and_cycling_as_transport _modes.htm\#_1.2.2_Cycling_as [z dn. 07.04.2010].

${ }^{29}$ Ministerie van Verkeer en Waterstaat, Cycling in the Netherlands, 2009, s. 11.

30 Tamże. 
Często stawia się pytanie, dlaczego w Holandii jest tak wielu rowerzystów. Wpływ na to ma kilka czynników. Oczywistym uwarunkowaniem jest ukształtowanie terenu. W Holandii mamy do czynienia z płaską powierzchnią ułatwiająca poruszanie się rowerem. Również aspekty historyczne odgrywają istotną rolę - tradycje związane z jazdą na rowerze są tam głęboko zakorzenione. Holendrzy są również świadomi zalet, jakie niesie jazda na rowerze. Jednak najbardziej trafną odpowiedź na pytanie, dlaczego w Holandii jest tak wielu rowerzystów, stanowi fakt, iż jazda na rowerze sprawia Holendrom dużo przyjemności.

Holendrzy używaja roweru do dojazdu do pracy, szkoły i sklepu. W godzinach szczytu występuje duża kongestia, dlatego rower jest atrakcyjna alternatywą dla pracowników, aby w jak najkrótszym czasie dotrzeć do i z pracy. Pracodawcy staraja się zapewnić wystarczająca liczbę miejsc parkingowych, żeby zachęcić pracowników do korzystania z rowerów. Większość ankietowanych Holendrów przyznała, że akceptowalnym czasem dojazdu do pracy jest $30 \mathrm{~min}$. Rowerzysta $w$ ciągu pół godziny jest $w$ stanie pokonać przeciętnie dystans $7,5 \mathrm{~km}$. Ciekawostką jest to, iż inne badania wykazały, że przeciętny Holender mieszka ok. $8 \mathrm{~km}$ od miejsca pracy ${ }^{31}$. Według przepisów wprowadzonych w Holandii, każda organizacja biznesowa jest zobligowana do działań na rzecz minimalizacji emisji gazów, które powstaja w wyniku dojazdu do i z miejsca pracy. Jest to równoznaczne $z$ promocja roweru. Zaproponowano także system przydzielania pracownikom pewnej kwoty pieniędzy do wykorzystania na cele komunikacyjne. $Z$ tych środków pracownicy moga kupić bilety komunikacji miejskiej, zapłacić za opłaty parkingowe lub wykupić paliwo do swojego samochodu. Pieniadze, które nie zostaną wydane, pracownik może zatrzymać. Ponieważ rower jest najtańszym środkiem transportu, pracownicy wykorzystujący go maja spory dodatek do pensji. Niektóre firmy stosuja nawet "służbowe" rowery. To stymuluje moralnie pracownika do korzystania z roweru. Innowacyjnym rozwiązaniem $\mathrm{w}$ dziedzinie zachęcania pracowników przez firmy do korzystania z rowerów jest system Trappers (hol. pedały). System rozpoznaje, kiedy dany rower jest w okolicy miejsca pracy i przyznaje punkty za korzystanie z roweru. Punkty te pracownik może później wymienić na nagrodę.

Wykorzystanie roweru w dojazdach do szkoły wzrasta z wiekiem uczniów. Szkoły są często usytuowane przy wąskich i ciasnych uliczkach, 
co uniemożliwia dotarcie samochodem oraz jego postój. W wielu miastach powszechne staje się budowanie strzeżonych parkingów rowerowych przy szkołach.

Holendrzy również wybieraja rower jako środek transportu do sklepu. Wielu sprzedawców nie jest zadowolonych z tej decyzji: z badań wynika, iż klienci, którzy przyjechali do sklepu na rowerze, spędzają w nim mniej czasu i robia mniejsze zakupy. Niemniej jednak odwiedzaja sklep częściej. Tutaj pojawia się konflikt, gdyż wielu sprzedawcom zależy, aby możliwy był dojazd do sklepu samochodem.

Jeśli chodzi o rekreację, to jazda na rowerze zaraz po spacerowaniu stanowi popularna formę spędzania wolnego czasu. W Holandii istnieje wiele dróg rowerowych, umożliwiających dojazd do atrakcji turystycznych, miejsc zakwaterowania i odpoczynku. Większość z nich jest specjalnie oznaczona.

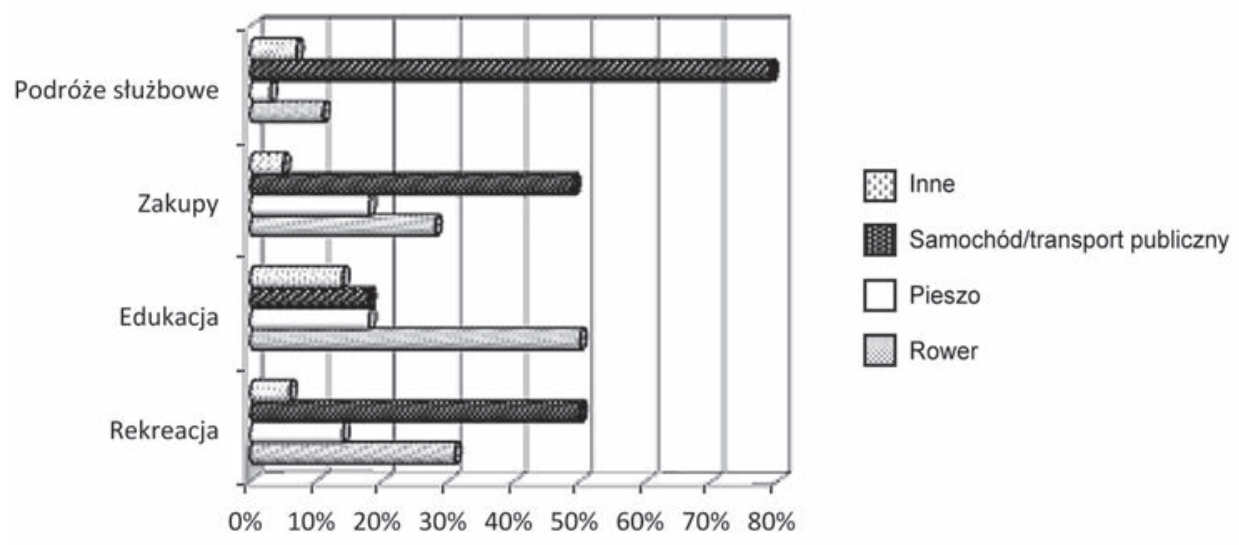

Wykres 2. Podział na cele podróży i sposoby ich realizacji

Źródło: jak do wykresu 1

Ważna we wspieraniu rozwoju transportu rowerowego jest jego intermodalność. Rower stanowi doskonałe dopełnienie podróży na dłuższych dystansach. To połączenie oferuje wiele zalet: rowerem podróżujący dojeżdża do miejsca, gdzie przesiądzie się na inny środek transportu bez czekania, a środkami transportu publicznego może w sposób szybki i wygodny dojechać do miejsc dalej położonych. Różne środki transportu uzupełniaja się, tworząc razem silny łańcuch. Około $40 \%$ podróżnych używa roweru do poruszania się pomiędzy miejscem 
zamieszkania a stacja kolejowa bądź przystankiem autobusowym. Tak duża liczba wynika prawdopodobnie z faktu, iż ponad $45 \%$ społeczeństwa holenderskiego mieszka $\mathrm{w}$ promieniu $3 \mathrm{~km}$ od najbliższej stacji kolejowej badź przystanku ${ }^{32}$.

$Z$ powodu istotnego wzrostu intermodalnego wykorzystania roweru zaczyna brakować miejsc parkingowych na głównych holenderskich dworcach. W szczytowym momencie na Dworcu Centralnym w Amsterdamie znajduje się 10 tys. rowerów ${ }^{33}$. Siła transportu intermodalnego w dużym stopniu zależy od zaplecza infrastrukturalnego, m.in. liczby miejsc parkingowych. Kolej Holenderska, będąca właścicielem infrastruktury kolejowej, pracuje obecnie nad projektem zakładającym utworzenie na każdym dworcu kolejowym miejsc parkingowych dla rowerów, zarówno strzeżonych, jak i niestrzeżonych.

W wielu miastach europejskich projekt roweru miejskiego został dobrze przyjęty i prężnie działa. Niemniej jednak w Holandii, z uwagi na dużą liczbę posiadanych przez mieszkańców rowerów, nie ma takiego zapotrzebowania. Jednak właśnie ze względu na dużą liczbę rowerów i niemożliwość przewiezienia pociągiem przez każdego pasażera swojego roweru rozwinął się w Holandii system OV-fiets.

OV-fiets to system rowerów miejskich, którego głównym założeniem jest pokonanie dystansu od stacji kolejowej do miejsca pracy/ uczelni za pomoca wypożyczonego roweru. Wypożyczenie roweru jest bardzo proste i nie wymaga oczekiwania. Wystarczy posiadać bilet miesięczny kolejowy lub kartę klubową OV-fiets. Opłata za wypożyczenie roweru wynosi 2,85 euro na dobę. System ten chce wymusić na użytkownikach regularność, dlatego wymaga odnawiania ${ }^{34}$. Jest dostępny na większości stacji kolejowych (ok. 200 lokalizacji). Dodatkowo planuje się, aby system rowerów miejskich stał się dostępny także w innych często odwiedzanych miejscach ${ }^{35}$.

By Holendrzy częściej i z większą przyjemnością wybierali rower, konieczne jest wprowadzenie wielu udogodnień w miastach. Większość planów związanych z poprawą oraz rozwojem infrastruktury zapisanych jest $w$ politykach transportowych.

W kształtowaniu polityki rowerowej państwo odgrywa rolę doradczą. Władze państwowe zajmuja się przede wszystkim wspieraniem

32 Tamże, s. 10.

33 Tamże, s. 31.

34 Tamże.

${ }^{35}$ www.fietsberaad.nl/library/.../Catch\%20the\%200V-fiets\%20(English).doc [z dn. 13.03.2010]. 
polityki regionalnej oraz finansowaniem projektów. Za politykę rowerowa sa odpowiedzialne władze miast. Określa to nie tylko odpowiedzialność za infrastrukturę rowerowa, lecz również za wszelakie usprawnienia dla rowerzystów. Każde miasto wyznacza inne cele. Niektóre miasta wdrażaja niezależna politykę rowerowa, podczas gdy w innych jest ona częścia państwowej polityki transportowej. Przy wprowadzaniu niezależnej polityki ważne jest, aby departamenty w urzędach miast wiedziały o prowadzonych projektach i ze sobą współpracowały. Promocja jazdy na rowerze, wzrost bezpieczeństwa oraz stworzenie infrastruktury rowerowej sa przeważnie głównymi celami polityki rowerowej. W większych miastach Holandii oprócz wymienionych celów ważnym punktem jest ograniczenie plagi kradzieży rowerów. Władze miast przeprowadzają również praktyczne badania dotyczące "wąskich gardeł". Wyniki sa przekazywane specjalistom do analizy i zaproponowania udoskonaleń.

Finansowanie pochodzi z zasobów budżetowych. Miasta wykorzystują również zewnętrzne fundusze.

W Holandii istnieje wiele organizacji zajmujących się wspieraniem rozwoju transportu rowerowego. Najważniejsze z nich to ${ }^{36}$ :

1. Fiets Beraad - istnieje przy Ministerstwie Transportu. Jej głównym celem jest umocnienie transportu rowerowego w całkowitym udziale poszczególnych środków transportu oraz zwrócenie większej uwagi na ten rodzaj transportu w planowanych politykach transportowych. Składa się z 20 ekspertów współpracujących w zakresie zbierania informacji i ich dystrybucji oraz wymiany doświadczeń.

2. KpVV - wspiera władze miast, doradzając w zakresie praktycznych rozwiązań. Zajmuje się takimi aspektami, jak: polityka, mobilność, bezpieczeństwo, infrastruktura oraz transport publiczny.

3. CROW (Kenniscentrum voor Verkeer, Vervoer en Infrastructuur - Narodowe Centrum Informacji, Technologii Transportu i infrastruktury) - organizacja non-profit skupiająca firmy i jednostki samorzadowe, które pracuja wspólnie nad konstrukcja oraz zarządzaniem zarówno infrastrukturą drogowa, jak i innymi udogodnieniami związanymi z transportem.

4. Fietsersbond - holenderski związek rowerzystów. W jego skład wchodzi 33 tys. członków. Związek posiada ponad 130 oddziałów na terenie całej Holandii. Głównymi zadaniami, jakie sobie stawia, jest tworzenie

${ }^{36}$ www.transport-research.info:8080/web/programmes/browse_organisation.cfm [z dn.10.03.2010]. 
oraz konserwacja miejsc parkingowych, kampanie przeciwko rosnącej liczbie kradzieży rowerów, wzrost bezpieczeństwa rowerzystów i budowa ścieżek rowerowych.

5. Stichting Landelijk Fietsplatform - niezależna organizacja zajmująca się rekreacyjna jazda na rowerze. Wspiera rozwój ścieżek rowerowych sprzyjających relaksującym podróżom oraz dba o ich odpowiednie oznakowanie.

6. Senter Novem - agencja zajmująca się innowacjami w dziedzinie zrównoważonego rozwoju. Poszukuje rozwiązań pozwalających na rozwój działalności biznesowej w Holandii przy uwzględnieniu zdrowia społeczeństwa oraz kondycji środowiska naturalnego.

W rankingu miast rowerowych w Holandii od wielu lat zwycięża Groningen, z ponad 40-procentowym udziałem rowerów wśród środków transportu ${ }^{37}$. Miasto zawdzięcza swój sukces polityce, która od wielu lat jest konsekwentnie wdrażana w życie. Polityka ta zakłada ${ }^{38}$ :

- połączenie miejsc, gdzie powstaja nowe osiedla mieszkaniowe, z centrum miasta,

- eliminowanie sygnalizacji świetlnej, gdzie tylko jest to możliwe,

- jeśli sygnalizacja świetlna jest niemożliwa do usunięcia - tworzenie osobnych świateł dla rowerzystów,

- ulice, po których samochody poruszaja się w jednym kierunku, są dla rowerzystów ulicami dwukierunkowymi,

- pierwszeństwo ruchu rowerowego nad ruchem samochodowym.

W stolicy Holandii za promowanie roweru odpowiedzialny jest Infrastructuur Verkeer en Vervoer (Wydział Transportu i Infrastruktury). Departament ten doradza i pomaga we wdrażaniu polityki transportowej.

Amsterdam ma długa tradycję rowerowa. Jego XVII-wieczna zabudowa centrum z wąskimi uliczkami i wieloma kanałami sprzyja poruszaniu się pieszo bądź rowerem. W stolicy Holandii istnieje ponad 400 km ścieżek rowerowych ${ }^{39}$.

Nie bez powodu Holandia jest kojarzona już od tylu lat z rowerami. Kraj ten zdecydowanie wyróżnia się na tle innych krajów europejskich zarówno pod względem zaangażowania w propagowanie jazdy na rowerze, jak i dobrych praktyk w planowaniu rozwoju infrastruktury.

37 Ministerie van Verkeer en Waterstaat, Cycling in the Netherlands, 2009, s. 54-55.

38 D. Ligtermoet, Continuous and integral: The cycling policies of Groningen and other European cities, Fietsberaad, Rotterdam 2006, s. 21-22.

${ }^{39}$ www.iamsterdam.com/en/visiting/things-to-do/cycling [z dn. 16.11.2011]. 


\subsection{Innowacyjne rozwiązania $w$ infrastrukturze rowerowej w Holandii}

Holandia jest pionierem wielu rozwiązań w dziedzinie infrastruktury rowerowej. Inne kraje czerpią inspirację oraz wykorzystuja jej pionierskie rozwiązania. Projektowanie przyjaznej rowerom infrastruktury oznacza nie tylko bezpieczne ścieżki rowerowe, ale również funkcjonalne skrzyżowania czy też parkingi.

Organizacja CROW opublikowała w podręczniku Sign up for the bike (Postaw na rower) wymagania, które powinny spełniać elementy infrastruktury, aby nosiła ona miano przyjaznej ${ }^{40}$ :

- bezpieczeństwo - zapewnienie bezpieczeństwa wszystkim uczestnikom ruchu,

- bezpośredniość - umożliwienie jak najkrótszego dojazdu do wybranego celu,

- wygoda - umożliwienie płynnego przepływu ruchu,

- atrakcyjność - infrastruktura powinna komponować się z otoczeniem i korzystanie z niej powinno sprawiać użytkownikom przyjemność,

- spójność - elementy infrastruktury powinny tworzyć spójną całość i umożliwiać połączenie wszystkich źródeł oraz celów podróży.

Wymagania te sa powiązane z konkretnymi, mierzalnymi parametrami, pozwalającymi na zobiektywizowana ocenę projektu lub istniejacej infrastruktury. Jeśli któryś z wymogów nie jest spełniony, to należy przebudować infrastrukturę.

Rowerzyści potrzebuja nie tylko dobrze utrzymanych ścieżek, lecz również miejsc, gdzie będą mogli zaparkować swoje rowery łatwo, bezpiecznie oraz blisko punktu docelowego. W roku 1998 w Holandii zostały po raz pierwszy sformułowane wymagania jakościowe dla systemu parkingów rowerowych. Normy wytyczyli najwięksi producenci i dostawcy urządzeń parkingowych oraz związek rowerzystów. Standardy te zawieraja tylko wymagania funkcjonalne i mierzalne. Ustalone normy obejmuja takie aspekty, jak ${ }^{41}$ :

- łatwość umieszczenia roweru,

- łatwość zabezpieczenia,

- minimalizacja możliwości kradzieży lub uszkodzenia,

- trwałość,

- dostępność informacji o systemie.

${ }^{40}$ H. P. Groot, Postaw na rower. Podręcznik projektowania przyjaznej dla rowerów infrastruktury, CROW/Polski Klub Ekologiczny, Kraków 1999, s. 23.

${ }^{41}$ www. fietsersbond. nl/urlsearchresults. asp?itemnumber=13669\&viewtype=popup [z dn. 16.11.2011]. 
Miejsca parkingowe spełniające wymagania normy są oznaczone nalepką z logo Fietsparkeur.

Parkingi w Holandii są również istotnym elementem łączącym rower z publicznymi środkami transportu. Ponieważ pasażerowie chca podróżować wygodnie "od drzwi do drzwi”, ważne jest uwzględnienie możliwości zaparkowania roweru w miejscu, gdzie można się przesiąść na kolejny środek transportu, np. przy stacji kolejowej. Jeśli pasażer będzie musiał spędzić dużo czasu na poszukiwaniu wolnego miejsca lub iść pieszo od odległego parkingu, zdecydowanie wybierze samochód. Podobnym problemem jest deszcz: rowery stojące na zewnatrz staja się mokre i jazda nimi nie jest przyjemna. Dlatego w celu zapewnienia komfortu dojazdu do stacji rowerem, Koleje Holenderskie wprowadzaja wiele innowacji. Przykładem tego jest darmowy, kryty parking przy Dworcu Głównym w Groningen.

Przy stacji kolejowej został wybudowany podziemny, kryty parking rowerowy z ponad 4 tys. miejsc. Inwestycja ta kosztowała około $10 \mathrm{mln}$ euro ${ }^{42}$. Inicjatywę przebudowy przestrzeni przed dworcem zapoczątkował fakt ciągle niewystarczającej liczby miejsc oraz wpływu nieuporządkowanych rowerów na estetykę. Obecnie na dachu parkingu znajduje się jedna z częściej uczęszczanych tras, łącząca centrum miasta z dworcem. Parking ma charakter otwarty: na suficie są umieszczone otwory, dzięki którym światło dzienne wpada do podziemi. W celu zachowania przejrzystości, na parkingu wyeliminowano grube filary. Zamiast tego dach opiera się na wielu smukłych kolumnach umieszczonych pod niewielkim kątem, sprawiających wrażenie bardziej nonszalanckich. Przez środek parkingu biegnie ścieżka rowerowa. W celu zminimalizowania prędkości rowerzystów zostało wybudowane rondo. Kolejnym innowacyjnym rozwiązaniem zastosowanym na tym parkingu sa wielopoziomowe, ruchome stojaki. Dzięki temu systemowi użytkownikowi jest łatwiej zaparkować na wyższym poziomie. Co więcej, parking ma 24-godzinny nadzór. Na parkingu znajduje się zawsze trzech inspektorów. Nadzorują oni poprawność korzystania z parkingu, pomagaja $w$ znalezieniu wolnego miejsca oraz odbiorze roweru. Strażnicy to efektywna metoda walki z kradzieżami.

Czas, na jaki można pozostawić rower na parkingu, wynosi 28 dni. Strażnicy kontrolują raz w tygodniu, w nocy, długość postoju poprzez naklejenie oznakowania pomiędzy szprychami. Jeśli rower jest używany, naklejka jest rozdarta. Rowery z czterema nienaruszonymi naklejkami sa usuwane. Na tak dużym parkingu problem może stanowić

${ }^{42}$ www.fietsberaad. $\mathrm{nl} /$ index.cfm?lang $=$ en\&section $=$ Voorbeeldenbank\&mode $=$ list $\&$ ontwerpvoorbeeldPage $=$ Gebouwen $[z$ dn. 16.11.2011] . 
odnalezienie swojego roweru. W celu ułatwienia tego użytkownikom, na suficie zostały zamontowane litery ułatwiające lokalizację roweru.

Innowacyjne rozwiązanie zastosowano również przy Dworcu Centralnym w Amsterdamie. $Z$ powodu wielu prac remontowych prowadzonych w obrębie dworca władze miasta wybudowały tymczasowe parkingi rowerowe: wieżę, platformę oraz łódź. Wieża umieszczona jest w wodzie po stronie Dworca Centralnego, podczas gdy platforma i łódź po przeciwnej stronie. Wieża rowerowa została otwarta już w roku 2001 i obecnie jest w stanie pomieścić 2500 rowerów. W roku 2007 przeszła kapitalny remont i obecnie znajduje się tam 4 tys. miejsc parkingowych.

Podobnie jak dla parkingu w Groningen, użytkowanie jest darmowe, a czas pozostawienia roweru nie może przekraczać 28 dni. Parking jest również nadzorowany przez specjalna jednostkę ${ }^{43}$. Platforma rowerowa wraz z łodzią są w stanie pomieścić 1450 rowerów.

W celu lepszego wykorzystania dostępnej przestrzeni, na platformie znajduja się wielopoziomowe stojaki. Jest to pierwsze miejsce, gdzie tego rodzaju stojaki zostały wykorzystane na otwartej przestrzeni. Jeśli testy przebiegna pomyślnie, takie stojaki zostana wykorzystane $\mathrm{w}$ innych częściach miasta.

\section{Podsumowanie}

W wyniku analiz przeprowadzonych w niniejszym rozdziale sformułowano następujące wnioski:

- Dania i Holandia są krajami, gdzie udział podróży rowerowych jest największy w Europie.

- Polityka transportowa obu tych krajów w dużym stopniu skupia się na przyjaznej rowerzystom infrastrukturze.

- Zarówno w Danii, jak i Holandii sprawnie działaja systemy rowerów miejskich.

- Kopenhaga zyskała popularność wśród polityków na całym świecie dzięki innowacyjnym pomysłom w rozwiązywaniu problemów dużego miasta, takich jak zanieczyszczenie powietrza, kongestia czy nadwaga mieszkańców.

- Rozwiązania w zakresie infrastruktury rowerowej, zastosowane w miastach Kopenhaga, Odense, Groningen czy Amsterdam stanowia wzór do naśladowania dla innych krajów.

43 Tamże. 



\section{Uwarunkowania w zakresie lokalizacji infrastruktury dużych obiektów sportowych na terenie Łodzi}

Adam Majewski*

\subsection{Wpływ infrastruktury transportowej na funkcjonowanie miasta i regionu}

Wpływ infrastruktury transportu na rozwój oraz funkcjonowanie terenów zurbanizowanych i ich otoczenia jest znaczący. Odpowiedni stan infrastruktury transportowej regionu i związane $z$ tym połaczenia tranzytowe $z$ innymi miastami pociaggaja za sobą nowe inwestycje w różnych sektorach. Jednocześnie $z$ tego tytułu moga wynikać również pewne ograniczenia czy wręcz negatywne skutki. Infrastrukturę transportową można podzielić na ${ }^{1}$ :

- transport kolejowy,

- transport samochodowy,

- żeglugę śródlądową i morską (transport rzeczny i morski),

- transport lotniczy,

- transport rurociagowy.

Największy wpływ na rozwój regionu spośród wyżej wymienionych wydaje się mieć infrastruktura transportu drogowego. Aby móc wskazać ewentualne korzyści czy negatywne skutki oddziaływania drogi na dany teren, należy dokonać rzetelnej analizy już na etapie projektowania i wyznaczania przebiegu trasy, uwzględniając przy tym założenie², że:

$$
\text { negatywne skutki < korzyści }
$$

Wskazana wyżej analiza powinna obejmować m.in. konsultacje społeczne oraz opinie ekologów.

* Lic. Adam Majewski - Katedra Logistyki, Wydział Zarządzania Uniwersytetu Łódzkiego, ul. Matejki 22/26, 90-237 Łódź.

1 J. Bendkowski, M. Kramarz, Logistyka stosowana. Metody, techniki, analizy, cz. 2, Wyd. Politechniki Śląskiej, Gliwice 2006, s. 307-308.

${ }^{2}$ R. Kozłowski, Wpływ infrastruktury transportu drogowego na rozwój regionu, [w:] R. Kozłowski, A. Sikorski (red.), Podstawowe zagadnienia współczesnej logistyki, Wolters Kluwer, Kraków 2009, s. 188. 
Do zadań, jakie mają spełniać drogi o wysokich parametrach (autostrady lub drogi ekspresowe) zaliczyć można: zapewnienie połączeń pomiędzy dużymi miastami, możliwość pokonywania dużych odległości w jak najkrótszym czasie, łączenie węzłów komunikacyjnych oraz stanowienie obwodnic zmniejszających ruch w aglomeracji. Istotne znaczenie dla rozwoju terenów zurbanizowanych maja węzły komunikacyjne, czyli skrzyżowania szlaków komunikacyjnych. Wśród nich wyróżnić można węzły: drogowe, drogowo-kolejowe, a także drogowo-lotnicze. Ponadto węzły komunikacyjne pełnia ważną rolę w rozwoju logistyki, ze względu na lokalizowanie się w ich sąsiedztwie dużych centrów i przedsiębiorstw logistycznych.

Poza korzystnym wpływem autostrad i dróg szybkiego ruchu, wyróżnia się także negatywne skutki ich oddziaływania. Zalicza się do nich m.in. hałas, wibracje i spaliny; niekorzystny wpływ na przyległe tereny rolnicze i otaczająca przyrodę; możliwość zanieczyszczenia wód powierzchniowych i podziemnych oraz trudności z fizycznym przekraczaniem tych szlaków.

Ponadto, aby spotęgować skutki pozytywne i wyeliminować negatywy związane z funkcjonowaniem dróg wysokiej klasy, stosuje się pewne sposoby ograniczania ich niekorzystnego wpływu. Sa to: budowa wiaduktów - niezwykle ważna dla społeczności lokalnej; wjazdy i zjazdy z autostrad - kosztowne, ale niezbędne dla prawidłowego ich działania; przejścia dla zwierząt - eliminujące sytuacje wtargnięcia fauny na drogę. Poza wyżej wymienionymi wyróżnia się: niwelujące hałas ekrany akustyczne, oczyszczające powietrze drzewa i krzewy - sadzone w tym celu wzdłuż przebiegu trasy, a także oczyszczalnie ścieków, separatory substancji ropopochodnych i zbiorniki ekologiczne.

Infrastruktura transportu jest powiązana ze zrównoważonym rozwojem. Stopień postępu w danym regionie zależy od wielu czynników, wśród których istotną rolę odgrywa stan infrastruktury transportowej. Problem rozwoju terenów zurbanizowanych pojawia się niemalże przy każdej nowej inwestycji infrastrukturalnej. Wyzwania, z którymi musi się zmierzyć koncepcja zrównoważonego rozwoju to ${ }^{3}$ :

- minimalizowanie obciążeń transportowych dla aglomeracji,

- osiagnięcie pewnych standardów związanych z ochrona środowiska i bezpieczeństwem,

${ }^{3}$ E. Staszewska, G. Bigda, S. Twaróg, D. Zarębski, Zrównoważony rozwój i jego wyzwania dla logistyki, [w:] P. Golińska (red.), Ekologiczne i ekonomiczne aspekty logistyki, Wyd. Politechniki Poznańskiej, Poznań 2009, s. 52-53. 
- poszukiwanie nowych proekologicznych źródeł energii, co wpływa na możliwie najmniejszą zależność transportu od ropy naftowej.

W Europie podejmowane są liczne działania mające na celu realizację wspomnianej koncepcji. Sa to m.in. projekty CIVITAS, CUTE oraz GUTS ${ }^{4}$.

Korzystny wpływ transportu na gospodarkę to wynik m.in. inwestowania $\mathrm{w}$ infrastrukturę transportu oraz poprawy działania całego systemu transportowego. $W$ ten sposób sprawnie funkcjonujący system transportowy odgrywa znacząca rolę we wzroście aktywizacji gospodarczej i zwiększa mobilność społeczeństwa. Budowanie nowych szlaków komunikacyjnych przekłada się na rozwój takich sektorów, jak usługi, handel, turystyka, produkcja (ilustruje to rys. 16).

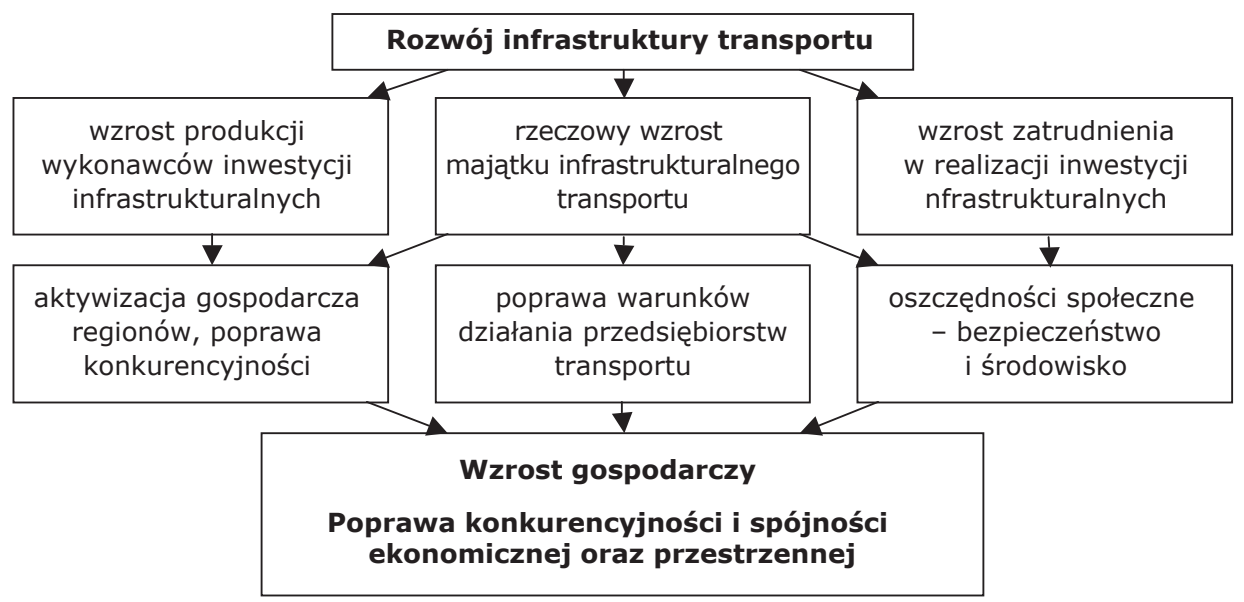

Rysunek 16. Wpływ rozwoju infrastruktury transportu na rozwój gospodarczy

Źródło: T. Rokicki, Podstawowe procesy logistyczne, [w:] J. Kiryjow (red.), Logistyka. Wybrane zagadnienia, Wyd. SGGW, Warszawa 2008, s. 80

Oddziaływanie na dany region wywierają również korytarze transportowe. W Unii Europejskiej sa to wytyczone (w 1994 r.) sieci, w skład których wchodzą m.in. drogi, linie kolejowe, porty lotnicze, śródlądowe szlaki żeglugowe i terminale transportu kombinowanego. Sa to najważniejsze elementy infrastruktury liniowej oraz punktowej. Do zadań krajów, przez które przebiegaja korytarze, należy budowanie, remontowanie i usprawnianie infrastruktury transportowej. Na terenie Polski znajdują się cztery takie korytarze.

\footnotetext{
${ }^{4}$ Szerzej: tamże, s. 54-55.
} 
System infrastruktury transportu tworza jej poszczególne gałęzie. Rozwój każdego z elementów wpływa w określony sposób na funkcjonowanie pozostałych gałęzi. Można tutaj wskazać problem komplementarności oraz substytucyjności.

Komplementarność może oznaczać spójność w całym systemie infrastrukturalnym. Rozwój nowych technologii spowodował, iż wzajemne powiązania poszczególnych gałęzi doprowadziły do ich pełnej integracji. W efekcie powiązania o charakterze komplementarnym moga wywoływać ${ }^{\mathrm{m}}$.in. możliwość połączenia izolowanych dotychczas systemów infrastruktury transportowej, istotny wzrost nakładów inwestycyjnych zwiazzanych z wprowadzeniem technologii o charakterze międzygałęziowym, zobligowanie do koordynacji planów rozwoju różnych gałęzi transportu, konieczność międzygałęziowej koordynacji procesu inwestycyjnego.

Kwestia substytucyjności wywołuje również określone problemy rozwoju infrastruktury. W praktyce niemożliwy jest równomierny rozwój wszystkich gałęzi transportu, z uwagi na cechy infrastruktury. Może się zdarzyć tak, że modernizowana aktualnie gałąź będzie skupiać z tego tytułu korzyści, co z kolei wywoła negatywne skutki dla gałęzi substytucyjnej. Z tego względu podejmowanie poważniejszych przedsięwzięć na drogach substytucyjnych gałęzi powinno być poprzedzone wnikliwą analiza możliwych skutków dla nich obu.

Analizując sytuację poszczególnych regionów oraz stopień zróżnicowania ich rozwoju, warto zastanowić się, co poza poziomem infrastruktury transportowej decyduje o takim stanie rzeczy. Logistyka wskazuje na logistykochłonność ${ }^{6}$. Jest to szereg składników (w tym także stanu infrastruktury), które decyduja o atrakcyjności regionu z punktu widzenia logistyki. Wśród wielu czynników pozwalających określić poziom logistykochłonności miasta lub regionu można wymienić te związane z infrastruktura ${ }^{7}$ :

- gęstość dróg kołowych i linii kolejowy ch na 100 km² obszaru,

${ }^{5}$ K. Wojewódzka-Król (red.), Rozwój infrastruktury transportu, Wyd. Uniwersytetu Gdańskiego, Gdańsk 1999, s. 26.

${ }^{6}$ Szerzej: W. Starzyńska, W. J. Rogalski (red. ), Logistyka szansą rozwoju miasta i regionu na przykładzie ziemi piotrkowskiej, Naukowe Wydawnictwo Piotrkowskie, Piotrków Trybunalski 2008, s. 379-380.

7 E. Gołembska, Rola i zadania logistyki międzynarodowej w integracji przedsiębiorstw Unii Europejskiej, Wyd. Akademii Ekonomicznej w Poznaniu, Poznań 2005, za: W. Starzyńska, W. J. Rogalski (red.), Logistyka szansą rozwoju..., s. 380. 
- liczba portów lotniczych, portów żeglugi śródlądowej lub morskiej danego terenu,

- tempo rozwoju transportu międzygałęziowego.

\subsection{Infrastruktura transportu $i$ inne determinanty lokalizacji ważnych dla miasta inwestycji}

Problem lokalizacji istotnych dla miasta obiektów jest niezwykle ważny. Ustawa o zagospodarowaniu przestrzennym z 1994 r. (wielokrotnie nowelizowana) daje samorządom lokalnym swobodę w planowaniu swojego rozwoju. Stwarza to ogromną szansę na poprawę stanu infrastruktury i umiejscowienie strategicznych dla aglomeracji inwestycji zgodnie z interesami mieszkańców.

Funkcjonowanie i rozwój infrastruktury transportu istotnie wpływa na przestrzenne układy systemów gospodarczych. Jest to jeden z czynników, który aktywnie współdziała w przestrzennej reorientacji miast oraz wielkich systemów gospodarczych. Innowacyjne rozwiązania techniczne w systemie transportu spowodowane są ciągłym dążeniem do możliwie najszybszego i generującego najmniej kosztów przewozu osób i ładunków.

Najwięcej wytycznych spośród wszystkich gałęzi transportu dotyczy infrastruktury transportu lotniczego. Przede wszystkim istnieja poważne ograniczenia dotyczące zabudowy w rejonie lotniska. Najważniejszym czynnikiem jest bezpieczeństwo, dlatego port lotniczy powinien być zlokalizowany jak najdalej od zabudowań. Na wysokość sąsiednich obiektów również nałożone są ograniczenia. Za przeszkody lotnicze uważa się budynki przekraczające $100 \mathrm{~m}$. Ponadto problem stanowią napowietrzne linie energetyczne, jeżeli ich odległość od końców pasów startowych jest mniejsza niż $4 \mathrm{~km}$.

Wśród wielu czynników decydujących o atrakcyjności inwestycyjnej danego obszaru można wskazać marketing terytorialny. Odgrywa on istotną rolę w kształtowaniu wizerunku miasta (bardzo często decydującego o lokalizacji w danym mieście przedsięwzięć infrastrukturalnych lub gospodarczych) ${ }^{8}$. "Marketing terytorialny jest narzędziem w zarzadzaniu rozwojem [...] miasta w taki sposób, aby swego rodzaju złożony megaprodukt, jakim jest miasto, zaspokoił zidentyfikowane

${ }^{8}$ Szerzej: T. Markowski (red.), Marketing terytorialny, Komitet Przestrzennego Zagospodarowania Kraju PAN, Warszawa 2006, s. 168. 
i antycypowane potrzeby klientów w zamian za uzyskane korzyści dla określonego terytorium, traktowanego jako terytorialnie określony upodmiotowiony «zbiór» mieszkańców"9. Publiczny charakter instytucji, jaka jest miasto, wymaga, aby orientację na zysk (rozumiana tutaj jako istota marketingu) widzieć nie tylko w kontekście korzyści finansowych, ale przede wszystkim jako rozwój miasta w wielu aspektach.

Wspomniany w powyższej definicji megaprodukt oznacza wszelkie korzyści aglomeracji, czyli bilans efektów zewnętrznych - pozytywnych i negatywnych, nazywany bardzo często także efektem synergicznym tworzącym wartość dodana.

Leszek Kupiec zauważa, iż infrastruktura transportowa wpływa na rozmieszczenie w przestrzeni innych elementów gospodarki poprzez pewne funkcje, które można jej przyporządkować ${ }^{10}$ :

- lokacyjna - określony poziom rozwoju infrastruktury transportowej danego obszaru pobudza lub blokuje stopień koncentracji ludności,

- lokalizacyjna - infrastruktura transportu jest jednym z czynników oddziałujących na rozmieszczenie określonych punktów w przestrzeni,

- przestrzenna - sprowadza infrastrukturę do roli czynnika kształtujacego układ przestrzenny w środowisku geograficznym,

- aktywizacyjna - przy pewnych założeniach, poprzez rozwój infrastruktury określonego regionu można osiągnąć wzrost społeczno-gospodarczy,

- transportowa - działalność transportowa warunkuje związki i wzajemne relacje łączące transport, gospodarkę i społeczeństwo, jako konieczne do rozwoju i niedające się zastapić.

Odpowiedni zasób infrastruktury korzystnie wpływa na lokalizację podmiotów gospodarczych oraz przyczynia się do aktywizacji gospodarczej regionu. Ponadto zwiększa możliwość przestrzennej koncentracji przepływu towarów, ludzi, informacji. Może się także przyczyniać do spójności oraz jedności danego terytorium. Istotny jest również czynnik otwartości terytorium, na który wpływ ma także system infrastruktury. Kluczowym wydaje się element konkurencyjności terytorium na szczeblu regionalnym i światowym.

${ }^{9}$ T. Markowski, Zarządzanie rozwojem miast, Wyd. Naukowe PWN, Warszawa 1999, s. 223.

${ }^{10}$ L. Kupiec (red.), Gospodarka przestrzenna. Lokalizacja w gospodarce przestrzennej, t. 3, Wyd. Uniwersytetu w Białymstoku, Białystok 1999, s. 84-86. 


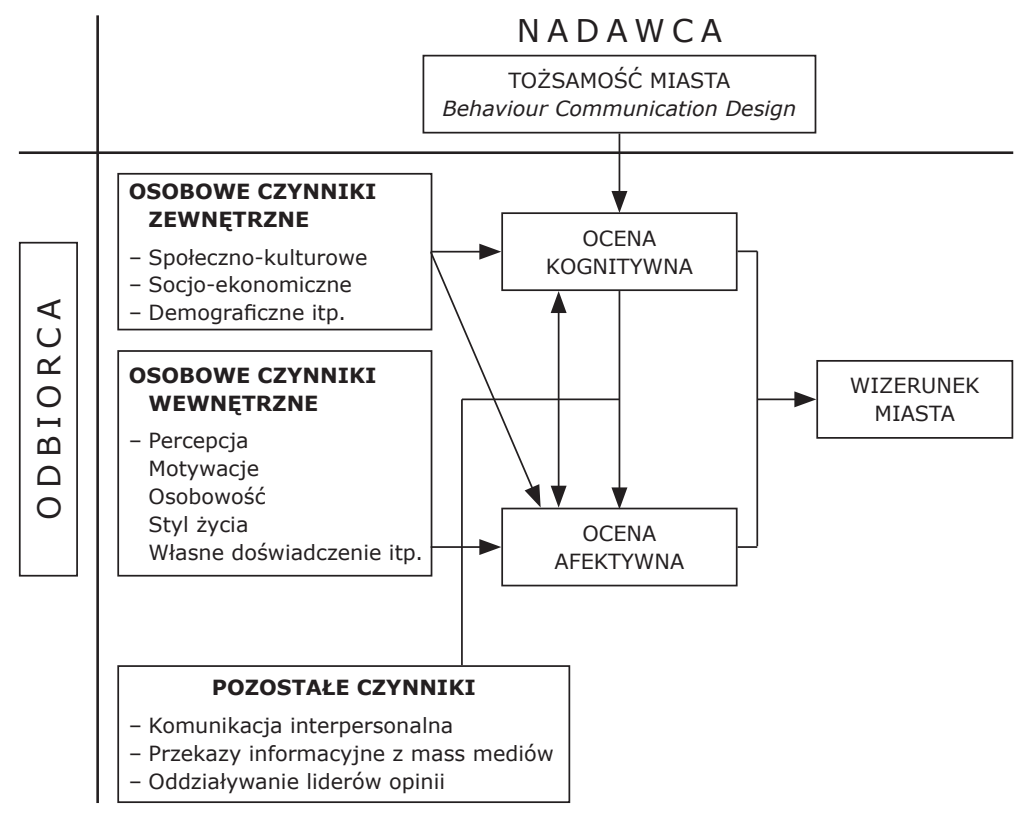

Rysunek 17. Ogólne determinanty wizerunku miasta

Źródło: T. Markowski (red.), Marketing terytorialny, Komitet Przestrzennego Zagospodarowania Kraju PAN, Warszawa 2006, s. 169

\subsection{Charakterystyka infrastruktury transportowej regionu łódzkiego}

Podejmując się charakterystyki infrastruktury transportowej regionu łódzkiego, warto dokonać takiej analizy w dwóch etapach. Pierwszy powinien dotyczyć obecnego stanu, natomiast drugi - uwzględniać plany, najbliższe inwestycje i stan łódzkiej infrastruktury po realizacji tych projektów.

Region łódzki jest terenem, który w najbliższej przyszłości ma szansę wykorzystać rozwój komunikacji drogowej w Polsce. Potencjał, który powstanie po wybudowaniu wszystkich planowanych inwestycji infrastrukturalnych, ma ogromne znaczenie dla rozwoju logistyki tego obszaru. Poniżej został scharakteryzowany obecny stan łódzkiej infrastruktury transportowej.

Infrastruktura kolejowa. Aktualna kondycja łódzkiej kolei nie jest najlepsza. Znakomite warunki wynikajace z centralnego położenia miasta nie zagwarantowały jej właściwego rozwoju. Lata zaniedbań, 
świadomej polityki, jak również tendencji zmniejszania znaczenia kolejnictwa w Polsce doprowadziły do stanu, w którym wiele linii kolejowych omija Łódź. Nieczynna od kilku lat jest linia kolejowa łącząca Łowicz przez Głowno i Zgierz z Łodzią Kaliską. Modernizacja trasy łączącej Łódź z Warszawa jest realizowana od kilku lat, ale nadal nie została ukończona. Na rozpoczęcie oczekuje II etap projektu, obejmujący prace na odcinku Skierniewice-Warszawa. Wprawdzie aglomeracja łódzka posiada kilka większych dworców kolejowych (można tutaj wskazać Fabryczny, Kaliski, Widzew, Żabieniec czy Chojny), ale większość z nich potrzebuje znacznego dofinansowania i już dawno straciła swoja świetność. Wyjątkiem może być Łódź Kaliska, największa i stosunkowo najbardziej rozwinięta stacja w regionie, modernizowana w latach 90.

Perspektywy, jakie stoją przed łódzką infrastrukturą kolejowa, pozwalaja spojrzeć na sprawę z nieco większym optymizmem. Przede wszystkim ruszyła długo oczekiwana budowa nowego podziemnego dworca Łódź Fabryczna, a wraz z tą inwestycją rozpocznie się budowa liczącego ok. $1600 \mathrm{~m}$ długości tunelu w kierunku Widzewa. W ten sposób zyska również Łódź Widzew - przedsięwzięcie jest w trakcie realizacji. Plany inwestycyjne obejmują również tereny otaczające dworce: budowę parkingów, renowację dworca autobusowego Łódź Centralna, stworzenie odpowiedniego zaplecza gastronomicznego oraz reorganizację linii komunikacji miejskiej.

Końca modernizacji ma szansę doczekać się również linia kolejowa łącząca Łódź ze stolicą. Pomóc w tym może wznowienie ruchu kolejowego na linii Łowicz-Głowno-Zgierz-Łódź Kaliska. Inwestycja ta zostanie zrealizowana w ramach Regionalnego Programu Operacyjnego. Spowoduje to znaczne skrócenie czasu podróży na szlaku Łódź Kaliska-Warszawa przez Łowicz.

Koncepcja budowy szybkiej kolei w Polsce również wygląda bardzo obiecująco dla Łodzi. Nazwana (ze względu na kształt, który jej przebieg przypomina) „linią szybkiej kolei $Y^{\prime \prime}$, ma łączyć aglomerację warszawska, łódzką, kalisko-ostrowską, poznańską i wrocławską. Rozpoczęcie jej budowy jest planowane dopiero na przełom roku 2013/2014, a pierwszy etap tej inwestycji zakłada połączenie Warszawy Centralnej z Łodzia Fabryczna.

Infrastruktura drogowa. Dla gospodarki większości krajów, w tym również Polski, sektor drogownictwa ma bardzo istotne znaczenie. Poziom rozwoju gospodarczego często zależy od stopnia zaawansowania inwestycji związanych z infrastrukturą drogową. 
W Polsce od kilku lat utrzymuje się trend rozbudowy sieci dróg krajowych i autostrad. Jednak dotyczy to tylko planów inwestycyjnych, w rzeczywistości jest dużo gorzej.

Region łódzki obecnie może „poszczycić się" tym, że ma przebiegająca przez miasto Łódź drogę krajową numer 1, która jest bardzo często zakorkowana, i która nie ma nic wspólnego z obwodnica. Z planowanych obwodnic istnieje tylko północna. Wschodnia obwodnica Łodzi w ogóle nie istnieje. Ma ja stanowić odcinek autostrady A1. Podobnie źle sprawa wygląda, jeśli chodzi o zachodnią i południowa stronę regionu. W tym przypadku w grę wchodza drogi ekspresowe. Sa to odpowiednio S14 oraz S8. Droga S14 w całości będzie znajdować się na terenie województwa łódzkiego, ma połączyć autostradę A2 z drogą ekspresową S8. Natomiast łódzki odcinek S8 to fragment drogi biegnącej przez Polskę od południowego zachodu na północny wschód.

Region łódzki ze względu na swoje strategiczne położenie w samym centrum Polski jest w uprzywilejowanej sytuacji. Większość inwestycji drogowych, które są lub będą realizowane, będzie bezpośrednio lub pośrednio dotyczyć Łodzi. Kluczowym miejscem jest Stryków pod Łodzia, gdzie krzyżują się autostrady A1 i A2. Jest to niezwykle atrakcyjny teren z punktu widzenia logistyki. Już teraz swoje centra logistyczne ulokowało tam wiele firm. Jeżeli doda się do tego drogi ekspresowe S8 i S14, to Łódź będzie chyba jedynym miastem w Polsce z czterema obwodnicami bardzo wysokiej klasy. Stwarza to olbrzymie szanse dla całego regionu na rozwój logistyki i sportu.

Infrastruktura lotnicza. Region łódzki może pochwalić się dwoma lotniskami. Największym i najbardziej znanym jest Port Lotniczy Łódź im. Władysława Reymonta nazywany także Lublinek, znajduje się w zachodniej części miasta. Drugim jest port lotniczy w Łasku.

Lotnisko w Łasku służy do celów wojskowych, znajduje się tu 32 Baza Lotnicza. Ponadto stacjonuja tutaj również myśliwce bojowe F-16. Istnieje koncepcja rozbudowy i przystosowania portu lotniczego do celów cywilnych. W ten sposób mogłyby się tutaj odbywać starty i lądowania samolotów pasażerskich. Jest to jednak nieokreślona terminowo i wciąż zawieszona inwestycja.

Łódź Lublinek jest międzynarodowym portem lotniczym, który posiada trzy terminale: Terminal General Aviation (dawniej Terminal 1) - zmodernizowany w 1997 r., Terminal Cargo - uruchomiony w 2009 r. oraz oficjalnie otwarty w czerwcu 2012 r. nowy Terminal 1 (w czasie budowy pod roboczą nazwą Terminal 3). Z tego tytułu użytkowany od 2005 r. tymczasowy Terminal 2 został zamknięty i rozebrany. 
Znaczenie portu lotniczego $w$ Łodzi w skali krajowej jest stosunkowo małe. Sytuacja z 2010 r., kiedy ze względu na remont warszawskiego Okęcia łódzkie lotnisko obsługiwało dodatkowe samoloty, pokazała, że Lublinek może stać się portem o dużym znaczeniu międzynarodowym. Istotne dla logistyki jest pojawienie się na łódzkim lotnisku terminalu cargo, mogacego obsługiwać samoloty towarowe.

\subsection{Lokalizacja obecnie istniejących obiektów sportowych}

Obecne położenie dużych ośrodków sportowych w Łodzi wydaje się bardzo dobre. Większość z nich spełnia podstawowe zasady dotyczące lokalizacji tego typu inwestycji.

Stan techniczny infrastruktury transportowej regionu łódzkiego nie jest zadowalający; większość planowanych inwestycji znajduje się tylko na papierze. Z obwodnic Łodzi istnieje tylko jej północna część. W planach inwestycyjnych wszystko wygląda dobrze, jednak terminy realizacji są ciaggle przesuwane lub $w$ ogóle nieokreślone. Mimo to trudno byłoby znaleźć lepszą od obecnej lokalizację dla już istniejących obiektów sportowych.

Wracając do wspomnianych wyżej prawideł, które są istotne przy wyborze usytuowania dużych obiektów sportowych, w Łodzi można wskazać:

- położenie stadionu jak najdalej od centrum miasta,

- zapewnienie dostępu korzystającym z obiektu do różnych gałęzi transportu (drogowy, kolejowy, lotniczy),

- umiejscowienie stadionu jak najbliżej istniejącej lub planowanej obwodnicy miasta (droga krajowa, droga ekspresowa, autostrada),

- duża dostępność komunikacji miejskiej.

Przestrzeganie powyższych zasad sprawia, że zapełnienie i opróżnienie obiektu jest możliwie najkrótszym procesem. Ponadto problem zakorkowania miasta zostaje znacząco ograniczony lub wręcz wyeliminowany.

Do największych obiektów sportowych w Łodzi zaliczyć można stadiony Widzew i ŁKS. Stadion Widzewa mieści się przy al. Piłsudskiego, w rejonie znajduje się modernizowany dworzec kolejowy Łódź Widzew. Natomiast stadion ŁKS usytuowany jest przy al. Unii Lubelskiej. Tuż obok zlokalizowany jest dworzec kolejowy Łódź Kaliska, w sąsiedztwie przebiega droga krajowa nr 1 . Ponadto ośrodek ma ułatwiony dostęp do lotniska, poprzez znajdujący się w niedalekiej odległości port lotniczy Lublinek. 
Na uwagę wśród większych obiektów sportowych w Łodzi zasługuje oddana do użytku w 2009 r. hala widowiskowo-sportowa Atlas Arena. Jest to jeden $z$ dwóch ${ }^{11}$ największych i najnowocześniejszych tego typu obiektów w Polsce. Inwestycja ta jest ogromną szansą na rozwój sportu i kultury w Łodzi, a także na organizację wielu przedsięwzięć o zasięgu międzynarodowym i - dzięki temu - promowanie miasta i regionu. Arena jest częścią kompleksu ŁKS i znajduje się tuż obok stadionu piłkarskiego.

Z punktu widzenia infrastruktury transportu hala jest bardzo dobrze umiejscowiona; dowodem na to sa liczne imprezy sportowe, kulturalne i rozrywkowe rangi międzynarodowej, które zakończyły się sukcesem organizacyjnym.

Jeszcze do niedawna rolę największej hali widowiskowo-sportowej w Łodzi pełnił obiekt MOSiR. Nazywany także "Łódzkim Pałacem Sportu", zlokalizowany przy al. Politechniki, był miejscem, w którym odbywały się wielkie imprezy sportowe i kulturalne - m.in. turniej finałowy siatkarskiej Ligi Mistrzów mężczyzn w 2008 r., mecze reprezentacji Polski siatkarzy w ramach Ligi Światowej oraz spotkania Skry Bełchatów w europejskich pucharach. Warto zauważyć, że oddana do użytku w 1957 r. hala była wówczas inwestycja, która wyróżniała się w całej Europie. Miejsce to było przez lata dumą łodzian, powszechnie uznawane za centrum sportowe, kulturalne, a nawet polityczne regionu ${ }^{12}$.

Z punktu widzenia logistyki położenie "Pałacu Sportu” w Łodzi nie powinno budzić większych zastrzeżeń. Na dobre uwarunkowania infrastruktury transportu $\mathrm{w}$ rejonie ośrodka wskazywać moga m.in. sąsiedztwo przebiegającej drogi krajowej $\mathrm{nr} 1$, jako szlaku tranzytowego, dostęp do ulicy Obywatelskiej i - co się z tym wiąże - połączenie ze znajdującym się niedaleko lotniskiem, a także lokalizacja dworca kolejowego Łódź Kaliska.

Obecny stan techniczny hali przy al. Politechniki nie jest najlepszy. Uwzględniając jednak wyżej przybliżoną historię obiektu, a przede wszystkim jego uwarunkowania infrastrukturalne, warto zadbać, żeby ośrodek był nadal użytkowany. Modernizacja obiektu sprawi, że Łódź będzie mogła eksploatować dwie duże hale widowiskowo-sportowe, co przyniesie dodatkowe korzyści dla miasta.

Ponadto wśród większych obiektów sportowych w Łodzi można wyróżnić stadion rugby, na którym swoje mecze rozgrywa zespół

\footnotetext{
${ }^{11}$ Drugim jest Ergo Arena na granicy Gdańska i Sopotu.

12 Szerzej: http://mosir.lodz.pl/serwis/index.php?str=19 [z dn. 30.10.2011].
} 
Budowlani Łódź oraz stadion żużlowy Orzeł Łódź, zlokalizowane odpowiednio na ulicy Górniczej oraz 6 sierpnia.

\subsection{Proponowana lokalizacja dużego przyszłego stadionu}

Kwestia budowy nowoczesnego stadionu w Łodzi jest bardzo złożona. Jednym z głównych czynników stojących na przeszkodzie powstania takiego obiektu jest wybór jego lokalizacji.

W większości miast, gdzie funkcjonuja co najmniej dwa równorzędne duże ośrodki sportowe, wybór umiejscowienia tego typu inwestycji jest dużym problemem. Optymalnym rozwiązaniem jest wybudowanie aren dla każdego z klubów. Wiąże się to jednak z dużymi kosztami, na co nie każde miasto może sobie pozwolić. Jako przykład można tutaj wskazać Londyn, gdzie istnieje kilka podobnych poziomem sportowym klubów i każdy posiada swój własny obiekt. Miastem, w którym udało się wybudować jeden duży stadion miejski, jest włoski Mediolan. "San Siro" jest arena zmagań AC Milan oraz Interu Mediolan.

Poniżej przedstawiona zostanie koncepcja własna autora dotycząca lokalizacji dużego przyszłego stadionu piłkarskiego dla Łodzi.

Łódź posiada dwa duże ośrodki sportowe, tj. Widzew i ŁKS. Każdy $z$ nich jest bardzo dobrze zlokalizowany pod względem infrastruktury transportowej. W związku z tym, idealnym miejscem dla przyszłego stadionu jest wybór jednego $z$ nich. W tym zestawieniu lepiej usytuowany wydaje się ośrodek ŁKS-u. Argumenty są bardzo mocne: przebiegająca tuż obok droga krajowa nr 1, dworzec kolejowy Łódź Kaliska, nieznacznie oddalony port lotniczy Lublinek i związana z nim ulica Maratońska stanowiąca połączenie $z$ lotniskiem; poza tym dobrze rozwinięta sieć transportu publicznego, wraz ze strategicznym znaczeniem ulic Wyszyńskiego i Konstantynowskiej jako szlaków komunikacyjnych wyprowadzających ruch na planowana budowę drogi ekspresowej S14. To wszystko sprawia, że przepustowość, czas zapełnienia oraz opuszczenia stadionu byłyby bardzo dobre. Warto w tym miejscu zauważyć, że takie rozwiazanie mogłoby, niestety, doprowadzić do eskalacji konfliktu społecznego na linii Widzew-ŁKS.

Alternatywnym rozwiązaniem dla lokalizacji stadionu jest wybór neutralnego miejsca dla obydwu ośrodków. Wydaje się to jednak nieuzasadnione ekonomicznie i logistycznie, zwłaszcza że trudno byłoby znaleźć w Łodzi takie miejsce. 
Uwzględniając wszystkie argumenty, powstaje wrażenie, że najbardziej odpowiednim rozwiązaniem jest budowa dwóch nowoczesnych stadionów w Łodzi. Jest to również rozwiązanie najbardziej prawdopodobne.

Stadion Widzewa powstałby za prywatne pieniadze inwestorów i byłby to typowo komercyjny obiekt. Rola miasta w tej inwestycji polegałaby na podjęciu działań związanych z infrastruktura otaczająca projekt. Większość środków na ten cel należałoby przeznaczyć na infrastrukturę transportowa, modernizację okolicznych ulic, budowę dużego parkingu oraz usprawnienie komunikacji miejskiej w rejonie stadionu. Kluczowym punktem infrastruktury transportu dla tej inwestycji jest al. Piłsudskiego jako sieć łącząca kompleks z lotniskiem. Zadaniem logistyki byłaby poprawa przepustowości na tym szlaku komunikacyjnym.

Drugi stadion zostałby zlokalizowany na miejscu obecnie istniejacego obiektu ŁKS-u. Projekt i budowę sfinansowałoby miasto. Infrastruktura transportowa otaczajaca ośrodek jest bardzo dobrze rozwinięta, więc nie są tutaj wymagane jakieś wielkie pieniądze. Tak jak to zostało wcześniej wspomniane, znajduje się tutaj sieć dróg miejskich i krajowych, dworzec kolejowy oraz nieznacznie oddalony port lotniczy. Poza tym planowana droga ekspresowa S8 oraz będące obwodnica Łodzi autostrady A1 i A2 zapewniaja połączenie ze wszystkimi miastami w Polsce. W przyszłości wskazane byłoby podjęcie drobnych prac modernizacyjnych komunikacji miejskiej.

Scharakteryzowana wyżej koncepcja nakłada na projekt budowy dużego nowoczesnego stadionu pewne obostrzenia. Podjęcie takiej inwestycji wiąże się z ograniczeniem rozmiaru takiego obiektu. W przypadku dwóch aren na terenie Łodzi, pojemność każdej z nich nie powinna przekraczać 30 tys. miejsc. Mocnym argumentem przemawiającym za takim rozwiązaniem jest możliwość organizowania jednocześnie dwóch dużych imprez w mieście. Nie spowoduje to znaczących utrudnień w funkcjonowaniu infrastruktury transportu, ze względu na możliwość wyprowadzenia ruchu poza miasto na wspomniana już wcześniej drogę S14. Istnieje natomiast szansa na zwiększenie korzyści z tego tytułu.

Koncepcja stworzenia dwóch stadionów w Łodzi, osobno dla Widzewa i ŁKS-u, wydaje się pomysłem funkcjonalnym. Koszty utrzymania aren rozłożą się na dwa ośrodki. Pojemność na poziomie 30 tys. miejsc pozwala organizować duże międzynarodowe imprezy. Przy tego typu obiektach istnieje większe prawdopodobieństwo, że przynajmniej kilka razy $\mathrm{w}$ roku stadion będzie zapełniony. Łódź nie potrzebuje wielkiego 
50-tysięcznego stadionu; taka inwestycja wymagałaby ciągłego dofinansowywania, a szansa na pełne wykorzystanie możliwości takiego obiektu jest niewielka. Ponadto, jak to zostało zauważone, istnieje problem natury społecznej - lokalizacji dwóch dużych klubów na jednym stadionie.

\section{Podsumowanie}

W wyniku analiz przeprowadzonych w niniejszym rozdziale można sformułować następujace wnioski:

- Infrastrukturę transportową można podzielić na: transport kolejowy, transport samochodowy, żeglugę śródlądową i morską, transport lotniczy oraz transport rurociagowy.

- Przy projektowaniu każdej nowej inwestycji drogowej spełniona musi być zależność: negatywne skutki < korzyści.

- Transport i ściśle związana z nim infrastruktura ma ogromny wpływ na cała gospodarkę, pociąga za sobą inwestycje i rozwój innych sektorów.

- Infrastruktura transportowa stanowi istotny punkt koncepcji zrównoważonego rozwoju.

- O wyborze lokalizacji danej inwestycji decyduje w znacznym stopniu odpowiedni stan infrastruktury transportowej.

- W kształtowaniu wizerunku miasta bardzo ważną rolę odgrywa marketing terytorialny.

- Infrastruktura transportowa regionu łódzkiego jest bardzo zróżnicowana.

- Większość inwestycji infrastrukturalnych w Polsce obejmuje swoim zasięgiem obszar województwa łódzkiego - stwarza to ogromna szansę rozwoju dla logistyki.

- Miasto ma dostęp do infrastruktury drogowej, kolejowej i lotniczej.

- Łódź, jako jedno z największych miast w Polsce, nie ma dużego, nowoczesnego stadionu piłkarskiego.

- W Łodzi istnieje kilka większych obiektów sportowych - wszystkie, poza nową hala widowiskowo-sportowa, sa przestarzałe i tym samym wyłączone z organizacji dużych imprez sportowych i kulturalnych.

- Miasto potrzebuje nowego dużego stadionu.

- Infrastruktura transportowa i rozwiązania logistyki miejskiej wskazują na lokalizację takiego obiektu na terenie obecnego stadionu ŁKS. 
- Autor proponuje koncepcję budowy dwóch obiektów w Łodzi: miejskiego, na terenie obecnego stadionu ŁKS, którego budowa zostanie sfinansowana przez miasto oraz prywatnego stadionu Widzew, sponsorowanego przez inwestorów.

- Dwa duże, nowoczesne stadiony zapewnią miastu możliwość organizowania większej liczby imprez sportowo-kulturalnych dużej rangi, nawet $w$ tym samym czasie.

- Proponowane rozwiązanie jest uzasadnione dobrymi uwarunkowaniami infrastruktury transportowej ośrodków ŁKS i Widzew. 



\section{Wpływ infrastruktury technicznej na rozwój regionu łódzkiego}

Małgorzata Okniańska*

\subsection{Wybrane zagadnienia dotyczące drogi $\mathbf{S 8}$ na analizowanym terenie}

Droga ekspresowa S8 stanowi strategiczny element układu drogowego regionu łódzkiego. Batalia związana z jej powstaniem i starania wielu osób uwieńczone zostały niewątpliwym sukcesem. Obecnie nadszedł czas realizacji przedmiotowego przedsięwzięcia. Śledząc doniesienia prasowe i komunikaty Generalnej Dyrekcji Dróg Krajowych i Autostrad, można zorientować się, że temat budowy drogi S8 cieszy się dużą popularnością. Jak wynika z artykułu zamieszczonego w prasie łódzkiej opisującej postępy prac na placu budowy przedmiotowej drogi, „podpisano umowy na budowę ostatnich czterech odcinków drogi ekspresowej S8 w województwie łódzkim"1. Obecnie można już mówić, że cała droga S8 jest w budowie.

Przy realizacji zadań inwestycyjnych o tak dużej skali zwraca uwagę kilka ważnych aspektów, których wyeksponowanie pozwoli pokazać złożoność infrastrukturalnego przedsięwzięcia drogowego. Ich istota jest wizerunek danego przedsięwzięcia, przekładający się na pozytywny lub negatywny odbiór medialny wśród mieszkańców strategicznej dla regionu inwestycji na obszarze, którego dotycza.

Opracowania planistyczne uwzględniały przedmiotowy korytarz drogowy w wielu dokumentach opisujących rzeczywistość funkcjonalno-przestrzenną regionu łódzkiego. Usytuowanie drogi S8 ujęte było również w planach zagospodarowania przestrzennego dla poszczególnych gmin, przez których teren droga ta miała przebiegać. Na użytek przedmiotowych dokumentów, a później na ich podstawie dokonano różnego rodzaju analiz kryteriów związanych z potrzebami przyszłego

* Mgr Małgorzata Okniańska - Katedra Logistyki, Wydział Zarządzania Uniwersytetu Łódzkiego, ul. Matejki 22/26, 90-237 Łódź.

${ }^{1}$ http://lodz.gazeta.pl/lodz/1,35153,10916574,Droga_S8_w_budowie_Podpisali_ ostatnie_umowy.html [z dn. 26.11.2012]. 
ruchu drogowego. Priorytetem w badaniach jest ustalenie przyszłego, docelowego natężenia ruchu pojazdów oraz ciągle rosnąca liczba pojazdów samochodowych. Badania takie przeprowadzane były m.in. w celu weryfikacji dwóch wariantów przebiegu drogi S8. W roku 2000 oraz 2005 przeprowadzano generalne pomiary i badania natężenia ruchu na kierunku do Sieradza. Jednocześnie uzyskano pomiary na trasie do Piotrkowa Trybunalskiego. Wyniki badań w pierwszym przypadku odzwierciedliły natężenie ruchu pojazdów na przedmiotowych odcinkach powyżej 10 tys. na dobę, natomiast w miastach - nawet do 18 tys. na dobę ${ }^{2}$. W zestawieniu pomiarów "na osi Wrocław-Bełchatów-Piotrków Trybunalski natężenie ruchu jest znacznie mniejsze i wynosi generalnie poniżej 10 tys. (w granicach 7-8 tys.) pojazdów na dobę" ${ }^{\prime \prime}$. Omawiane badania jednoznacznie pokazały, że północny wariant przebiegu drogi S8 jest zdecydowanie bardziej uzasadniony. W takiej sytuacji jak najszybsza realizacja budowy drogi zdecydowanie poprawi sytuację ruchu drogowego w województwie łódzkim. Na mapie 3 przedstawiono natężenie ruchu na poszczególnych odcinkach z uwzględnieniem dwóch wariantów drogi.

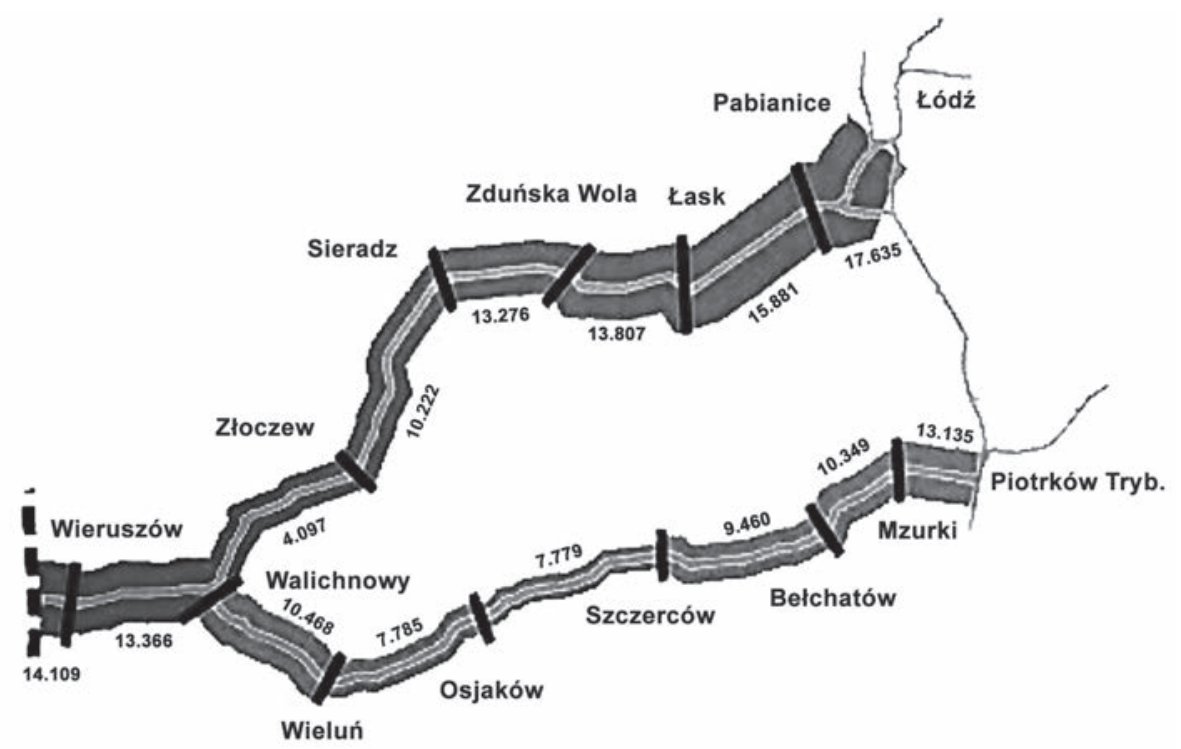

Mapa 3. Badania natężenia ruchu drogowego - stan na 2005 r.

Źródło: opracowanie - Anna Palczewska na podstawie: www.uni-logistics. eu/images/ruch_2005_s8_8_org.jpg [z dn. 21.02.2012]

2 E. Paturalska-Nowak, Droga Ekspresowa S-8 - element strategicznego układu drogowego województwa łódzkiego, prezentacja multimedialna, slajd nr 29 z 62.

${ }^{3}$ Tamże. 
Upływ czasu powoduje jednak dezaktualizację niektórych opracowań. Doskonałym przykładem jest właśnie natężenie ruchu pojazdów, które systematycznie ulega zwiększeniu. Wybiegając wprzód o 10 lat, należy przypuszczać, że wyniki pomiarów będą zdecydowanie wyższe. Dzięki badaniom można oszacować przyszłe korzyści nie tylko ekonomiczne, ale również te związane z bezpośrednim użytkowaniem dróg przez kierowców. Szacunkowo obliczono, że droga krajowa nr 14 (Łódź-Wrocław) w momencie powstania trasy S8 zostanie odciążona z ruchu pojazdów o ok. $65 \%$. Natomiast ruch pojazdów na drodze krajowej nr 12 (ŁaskPiotrków Trybunalski) zmniejszy się o $50 \%{ }^{4}$. Daje to skalę porównawczą do obecnej sytuacji na wspomnianych drogach. Do tego obrazu dochodza również zagadnienia zmniejszenia zanieczyszczenia powietrza (z tytułu mniejszej liczby aut) oraz zdecydowanego poprawienia się bezpieczeństwa ruchu drogowego. Pośrednio wpływać to będzie również na stopień zużycia eksploatacyjnego nawierzchni omawianych dróg.

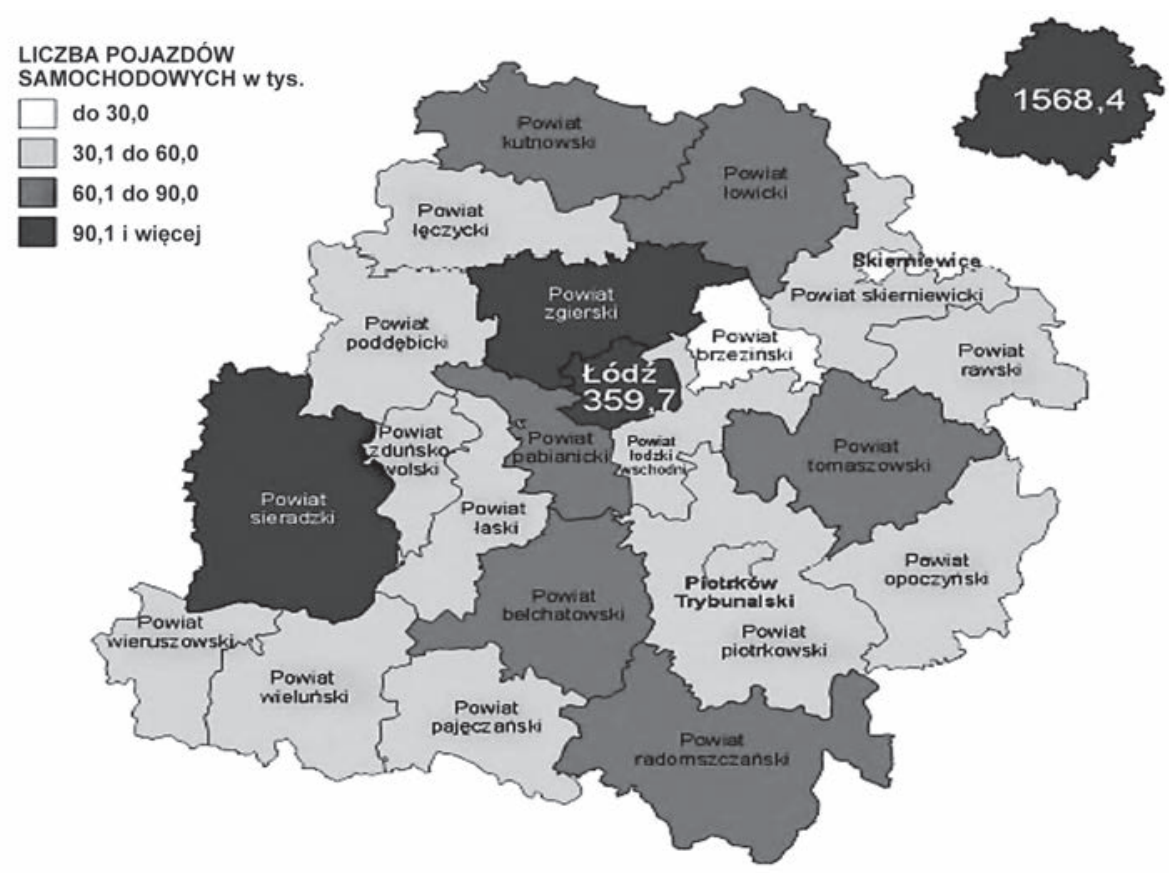

Mapa 4. Liczba pojazdów samochodowych w regionie łódzkim - stan na 2010 r.

Źródło: P. Armatys, Łódzki Ośrodek Badań Regionalnych, Urząd Statystyczny w Łodzi, 2009, s. 17

${ }^{4}$ Tamże, slajd nr 33 z 62. 
Z zagadnieniem natężenia ruchu drogowego nierozerwalnie wiąże się pojęcie liczby pojazdów samochodowych poruszających się po drogach. Dynamika wzrostu liczby aut jest znacznie większa niż tempo rozwoju infrastruktury drogowej. Zmusza to do ciagłego monitorowania sytuacji na danym obszarze (por. powiaty w województwie łódzkim - mapa 4).

Przedstawiona mapa ilustruje liczbę pojazdów samochodowych. Jak można ocenić, region łódzki charakteryzuje się dużym zróżnicowaniem liczby aut w poszczególnych powiatach, jednakże ich ilość szczególnie w obrębie aglomeracji łódzkiej oscyluje w wysokich wartościach. Im więcej pojazdów samochodowych, tym większe negatywne oddziaływanie na środowisko naturalne.

Aspekt ekologiczny przy realizacji tak znaczących inwestycji infrastrukturalnych ma bardzo duże znaczenie z punktu widzenia zrównoważonego rozwoju. Pogorszenie stanu środowiska naturalnego i zachwianie ekosystemu może pociągnąć za sobą nieodwracalne zmiany. Dlatego tak ważny jest problem oddziaływania na środowisko naturalne wszelkiego rodzaju inwestycji infrastrukturalnych. Inwestycja drogowa, jaka jest budowa drogi S8, nie powstałaby bez uzyskania przez inwestora - w tym przypadku jest nim Generalna Dyrekcja Dróg Krajowych i Autostrad - decyzji o środowiskowych uwarunkowaniach i decyzji o ustaleniu lokalizacji dla przedmiotowego przedsięwzięcia. Drogą do uzyskania takiej decyzji jest sporządzenie dokumentacji do wydania opinii dla wniosku o wydanie decyzji o zezwoleniu na realizację inwestycji drogowej5. Celem sporządzenia takiej dokumentacji jest przedstawienie i analiza powiązań obecnie istniejącego publicznego układu drogowego z nowym przedsięwzięciem infrastrukturalnym. Ważnym zagadnieniem jest również określenie zmian, które pojawią się w dotychczasowym układzie zagospodarowania przestrzennego terenu. Poprzez ogólną charakterystykę projektowanego przedsięwzięcia dokumentacja pokazuje przebieg drogi, usytuowanie skrzyżowań i zjazdów, przedstawia przebieg uzbrojenia i odwodnienia terenu. W dokumentacji takiej pokazuje się również kolizje z istniejącymi obiektami infrastrukturalnymi oraz najważniejsze parametry techniczno-użytkowe drogi. Dokumentacja do wniosku zawiera także aktualny wypis z rejestru gruntów, w granicach których przebiega linia rozgraniczająca nieruchomości oraz projektowana inwestycję $w$ postaci map zawierających projekty podziału nieruchomości gruntowych. Jednym z ważnych wyznaczników

${ }^{5}$ Dokumentacja do wydania opinii dla wniosku o wydanie decyzji o zezwoleniu na realizację inwestycji drogowej, s. 1. 
dokumentacji do sporządzania wniosku jest analiza "koncepcji rozwiązań technicznych wynikajacych z potrzeb ochrony środowiska, dóbr kultury i ochrony gruntów rolnych i leśnych"6. Istotnym aspektem, który jest przedmiotem prac nad określeniem decyzji środowiskowej, jest uwzględnienie interesów osób trzecich ${ }^{7}$. Analizie podlega:

- „zapewnienie dostępu do drogi publicznej,

- zapewnienie możliwości korzystania z urządzeń infrastruktury technicznej,

- zapewnienie dopływu światła dziennego do budynków mieszkalnych,

- ochrona przed zanieczyszczeniem powietrza, wody i gleby"8.

Dla przedmiotowej inwestycji została wydana przez Regionalnego Dyrektora Ochrony Środowiska w Łodzi decyzja o środowiskowych uwarunkowaniach (znak RDOŚ-10-WOOS/6613/1688/2010/mg) z dnia 8 stycznia $2010 r^{9}{ }^{9}$ Ubieganie się o tę decyzję oraz otrzymanie jej jest wymagane, ponieważ inwestycja jest zaliczana do „przedsięwzięć mogących znacząco oddziaływać na środowisko [...]"10. Po przeanalizowaniu i określeniu uwarunkowań, których wystapienie kwalifikuje dane przedsięwzięcie do sporządzenia raportu o oddziaływaniu na środowisko, w przypadku analizowanej trasy drogi S8 zalecane sa m.in. „pomiary emisji hałasu na etapie eksploatacji w rejonie węzłów z drogami krajowymi"11. Ponadto konieczne jest przeprowadzenie "analizy porealizacyjnej w zakresie oceny skuteczności zastosowanych urządzeń zabezpieczajacych"12. Decyzja o uwarunkowaniach środowiskowych jest wyrazem dbałości o środowisko naturalne w zakresie flory i fauny. Jak wiadomo, podczas prac zwiazanych z budowa drogi ulegaja zniszczeniu i degradacji siedliska zwierząt oraz roślin. W takim przypadku określa się zasady postępowania, których nadrzędną rola jest niwelacja zniszczeń i uszczerbku na środowisku naturalnym. Przedmiotowa decyzja nakazuje m.in. zaprojektowanie i budowę rozmaitej wielkości przejść dla zwierząt. Wiąże się to z zapewnieniem bezpieczeństwa ruchu drogowego. Także w tym celu na całej długości planowane jest

6 Tamże, s. 2.

7 Ustawa z dn. 7 lipca 1994 r. Prawo budowlane, Dz.U. z 2006 r., nr 156, poz. 1118 (art. 5.2).

${ }^{8}$ Dokumentacja do wydania opinii dla wniosku o wydanie decyzji..., s. 5.

${ }^{9}$ Decyzja o środowiskowych uwarunkowaniach dla realizowanej budowy drogi ekspresowej S-8.

10 Ustawa z dn. 3 października 2008 r. o udostępnianiu informacji o środowisku i jego ochronie oraz o ocenach oddziaływania na środowisko, Dz.U. nr 199, poz. 1227 z późn. zm.

${ }^{11}$ Decyzja o środowiskowych uwarunkowaniach dla realizowanej budowy..., s. 17.

12 Tamże. 
usytuowanie odpowiedniego rodzaju siatek ochronnych dla ptactwa. Pierwotnie planowane do likwidacji oczka wodne, będące naturalnym siedliskiem płazów, również maja być odbudowane i „pozostawione naturalnej sukcesji"13. Nie tylko zwierzęta są pod ochroną. W miejscach, gdzie droga S8 przebiega przez kompleksy leśne, nakazuje się przeprowadzić nasadzenia zieleni glebochronnej (zapobiegającej erozji gleby), drzew i krzewów odpowiednio dobranych pod kątem gatunkowym w taki sposób, aby "rośliny odporne były na zanieczyszczenia, mrozoodporne i dostosowane do warunków gruntowo-wodnych oraz dostosowane do istniejącej zieleni"14. Aspekt ekologiczny jest ważnym elementem pojawiającym się szczególnie w argumentach przeciwników powstania tak dużych inwestycji. Dokumentacja przedkładana do wydania decyzji środowiskowej dla danej inwestycji zakłada analizę trzech wariantów przebiegu drogi, które wymagane sa ustawowo ${ }^{15}$. Analizie poddawany jest "wariant proponowany przez wnioskodawcę, racjonalny wariant alternatywny oraz wariant najkorzystniejszy dla środowiska"16. Po przeprowadzeniu analiz przez niezależnych ekspertów, najlepszym wariantem przebiegu drogi w przypadku omawianej inwestycji jest wariant południowy ${ }^{17}, w$ decyzji środowiskowej oznaczony kolorem zielonym. Trasa przebiegu wariantu zielonego, przecinająca dolinę Grabi - terenu szczególnie atrakcyjnego turystycznie - nie przypadła ekologom do gustu. Nie trafiaja do nich żadne zdroworozsądkowe argumenty.

Koronnym argumentem przeciwko realizacji drogi S8 podnoszonym przez ekologów jest fakt, iż obszar doliny rzeki Grabi został niedawno uznany za teren NATURA 2000 w ramach Europejskiej Sieci Ekologicznej ${ }^{18}$. Jednakże w decyzji środowiskowej można przeczytać: „Inwestycja

13 Tamże, s. 15.

14 Tamże, s. 17.

15 Ustawa z dn. 3 października 2008 r. o udostępnianiu informacji o środowisku...

16 Tamże, rozdział 2, art. 66, pkt 5.

${ }^{17} \mathrm{Z}$ punktu widzenia całego przedsięwzięcia rozpatrywane były dwa warianty: północny, przebiegający przez Łódź oraz południowy, biegnący przez Piotrków Trybunalski. W tym przypadku został wybrany do realizacji wariant północny. Dokumentacja dotycząca ochrony środowiska wymaga przedstawienia trzech wariantów przebiegu projektowanej drogi. Tutaj został wybrany wariant biegnący po południowej stronie miasta Łask, oznaczony w dokumentacji kolorem zielonym. Wymienione wyżej warianty sa tożsame ze soba, za: http://sumorok.pl/index.php?option=com_content\&task=view\&i$\mathrm{d}=173 \&$ Itemid $=1$ [z dn. 25.02.2012].

${ }^{18}$ Europejska Sieć Ekologiczna NATURA 2000 to obszary, które posiadaja walory cenne przyrodniczo na terenie Unii Europejskiej. Celem stworzenia takiej sieci jest szczególna ochrona cennych pod względem przyrodniczym elementów zagrożonej flory i fauny Europy, za: http://przyroda.polska.pl/ochrona/natura2000 [z dn. 28.02.2012]. 
w wariancie 1 zielonym (południowym) została zaplanowana ze szczególnym uwzględnieniem obecności obszaru NATURA 2000 [...], a zachowanie jego zasobów i funkcji było priorytetem podczas planowania tego odcinka. [...] Dolina Grabi stanowi ważny korytarz ekologiczny i ta funkcja zostanie zdecydowanie zachowana. Zagadnienie ochrony zasobów i funkcji doliny Grabi stanowi priorytet planowanego przekroczenia obszaru [...] przez wariant preferowany"19. Wynika z tego jasno, że organy pozwalajace na realizację budowy drogi S8 maja świadomość ważności zagadnień ekologicznych. Z punktu widzenia ekologów jednak każde działania ich oponentów - w tym przypadku decydentów i projektantów - są niewystarczające, mało zasadne, pozbawione istotnych treści. Czasami pojawiają się również zarzuty o niekompetencję ekspertów czy też nierzetelność w dokumentacji. Z drugiej strony, wszelkie argumenty podnoszone przez ekologów trafiają na podatny grunt. Jest wiele osób niezadowolonych z realizacji budowy S8. Jej przeciwnicy stanowią jednak niewielki odsetek wśród rzeszy zwolenników tej inwestycji - są to z reguły osoby, których budowa trasy dotknie w sposób bezpośredni.

Omawiane zamierzenie infrastrukturalne, jak każde znaczące dla przestrzeni publicznej, jest inwestycja celu publicznego. Oznacza to, że jest ono ważne z punktu widzenia całego społeczeństwa jako ogółu, a także dla rozwoju regionu czy też województwa. Jednakże cała ta sytuacja wygląda inaczej w skali lokalnej, a już zupełnie odmiennie postrzegana jest z poziomu pojedynczego mieszkańca, będącego właścicielem kawałka ziemi, przez który omawiana droga będzie w przyszłości przebiegać. $Z$ taką sytuacją wiąże się niezwykle ważny problem wywłaszczeń mieszkańców. W tym miejscu ścierają się dwa przeciwstawne stanowiska. Z jednej strony, mieszkańcy danego obszaru maja świadomość potrzeby dużych inwestycji infrastrukturalnych - sprzyjaja one rozwojowi, podnoszą poziom życia, powoduja wzrost wartości terenów, przez które przebiegają. Użytkownicy dróg będą się cieszyć dogodnym dojazdem w komfortowych warunkach, dostępnością terenów, krótszym czasem przejazdu. Z drugiej jednak strony, na szali położone jest dobro właścicieli działek podlegających wywłaszczeniu. Dzieje się to na mocy specustawy ${ }^{20}$, która "określa zasady i warunki przygotowania inwestycji w zakresie dróg krajowych [...], w tym warunki lokalizacji i nabywania

${ }_{19}$ Uzasadnienie do decyzji o środowiskowych uwarunkowaniach dla realizowanej budowy drogi ekspresowej S-8, s. 38-39.

20 Ustawa z dn. 10 kwietnia 2003 r. o szczególnych zasadach przygotowania i realizacji inwestycji w zakresie dróg publicznych, Dz.U. z 2008 r., nr 193, poz. 1194 z późn. zm. 
nieruchomości na ten cel $[\ldots]^{\prime \prime 21}$. Każdy właściciel ziemi, przez która prowadzona będzie trasa, otrzymał zawiadomienie o wydaniu decyzji o zezwoleniu na realizację inwestycji drogowej22, wydane przez Łódzki Urząd Wojewódzki. Zawiera ono numery działek położonych w liniach rozgraniczających teren inwestycji, znajdujących się $w$ danym powiecie. Rozpoczęło się wówczas całe postępowanie związane z wywłaszczeniem, odszkodowaniami za przejęcie własności, a w zasadzie długim oczekiwaniem na ich wypłacenie. $Z$ punktu widzenia właścicieli działek jest to proces bolesny, okupiony stresem związanym z niepewnością jutra. Władze samorządowe organizuja z gospodarzami spotkania informacyjne, na których omawiana jest ich sytuacja prawna. Właściciele na bieżąco "informowani są o przebiegu, przejęciu, wykupie gruntów i terminach odszkodowań związanych z budową drogi ekspresowej S8 przez właściwe organy państwa"23. Nie zmienia to jednak faktu, że większość z tych osób czuje się skrzywdzona, traktowana w niegodny sposób, wręcz oszukana przez przedstawicieli władz lokalnych. Do nikogo nie dociera argument, że działania podejmowane są dla dobra wszystkich, dla celów wyższej użyteczności, bowiem w przeświadczeniu ludzi dzieje się to "na krzywdzie" gospodarzy.

Problem wywłaszczeń, niezależnie od regionu Polski, zawsze budzi kontrowersje. Jest powodem dramatów ludzi, którzy z pokolenia na pokolenie budowali swoje majatki. W ich rozumieniu teraz (w wyniku procesu wywłaszczenia) wszystko zostanie zmarnowane, a ich dorobek życia zaprzepaszczony. Jednakże trzeba mieć świadomość, że instytucja wywłaszczenia jest przewidziana prawem w Konstytucji RP, o ile sa spełnione dwa warunki: pierwszy warunek - wywłaszczenie odbywa się "na cele publiczne", drugi - następuje "wypłacenie słusznego odszkodowania"24. Niestety, trudno jest ludziom zaakceptować sytuację, w której pozbawiani są dorobku życia, dostając w zamian gratyfikację pieniężną niespełniajaca, w ich odczuciu, oczekiwań co do jej wysokości.

Decyzja o środowiskowych uwarunkowaniach uwzględnia i chroni również interesy "osób trzecich". Pojęcie to odnosi się do kolizji z istniejącymi urządzeniami, takimi jak sieci elektroenergetyczne, teletechniczne, wodociągowe czy też oświetlenia drogowego. Obejmuje też

${ }^{21}$ Tamże, rozdział 1, art. 1, pkt 1.

${ }^{22}$ Zawiadomienie o wydaniu decyzji o zezwoleniu na realizację inwestycji drogowej z dn. 7 września 2011 r.

${ }^{23}$ Fragment artykułu prasowego w tygodniku "Mój Łask", 28.12.2011, nr 7.

${ }^{24}$ Opracowanie własne na podstawie: P. Wojciechowski, Konspekt - podstawy prawa rzeczowego, cz. II: Własność i inne prawa rzeczowe. Formy władania nieruchomościami, Uniwersytet Warszawski, 2011, s. 3. 
różnego rodzaju instytucje w postaci budynków użyteczności publicznej lub terenów zamkniętych, na których usytuowane sa jednostki ważne z punktu widzenia obronności państwa. Odbywa się to poprzez zapewnienie dostępu do istniejących dróg publicznych na danym terenie, a także umożliwienie korzystania z urządzeń infrastruktury. Kluczowa jest zatem korelacja $z$ istniejacymi na danym terenie elementami infrastrukturalnymi funkcjonującymi w danej przestrzeni publicznej. Mając świadomość, że w gminie Łask funkcjonuje wojskowe lotnisko działajace $w$ ramach 32 Bazy Lotniczej, trzeba bezwzględnie określić, jaki wpływ będzie miała droga S8, stanowiąca element dotychczasowego układu drogowego, na wszelkie działania związane z wykonywaniem zadań bojowych oraz na sprawy dotyczące obronności. Z dostępnych dokumentów wynika, że w bliskim sąsiedztwie lotniska zlokalizowany będzie węzeł Łask, który mieści się na przecięciu z drogą krajową nr 12, na granicy z gminą Łask i gminą Dobroń.

Tak zlokalizowany węzeł umożliwi w przyszłości szybki i dogodny transport środków materiałowych, paliw oraz środków niebezpiecznych, których odpowiednia dystrybucja jest podstawa sprawnego działania i logistycznego wsparcia dla jednostki stacjonujacej na terenie lotniska. Przebieg drogi S8 w bezpośredniej bliskości umożliwi m.in. „szybkie podjęcie działań ratowniczych w przypadku awarii"25. Ponadto, biorąc pod uwagę specyfikę transportu wojskowego, konieczne jest maksymalne skrócenie czasu transportu, odbywającego się między oddalonymi jednostkami zlokalizowanymi na terenie województwa łódzkiego (Łask, Sieradz, Leźnica Wielka, Zgierz, Nowy Glinnik, Tomaszów Mazowiecki). Dzięki budowie trasy S8 zdecydowanie zwiększy się przepustowość transportu, a także zaistnieje możliwość transportu wielkogabarytowego. Zwiększenie nośności dróg pozwoli na powiększenie masy zestawów transportowych, co zdecydowanie polepszy ekonomiczny efekt wsparcia logistycznego. Bliskość drogi S8 dla lotniska daje również możliwość omijania miast i większych skupisk ludności przez kolumny transportowe lub przewożące materiały szczególnie niebezpieczne. Daje też wojsku sposobność do zastosowania transportu kombinowanego lądowo-powietrznego na linii Łask-cały świat, w ramach wsparcia logistycznego sił NATO26. Do pełnego obrazu trzeba dodać fakt, iż w przyszłości

${ }^{25}$ Pismo Senatora RP Andrzeja Owczarka do Ministra MON - dotyczy przebiegu drogi S-8 w okolicach lotniska wojskowego w Łasku, za: materiały udostępnione przez Biuro Senatorskie Senatora RP Andrzeja Owczarka, 2008.

${ }^{26}$ Opracowanie na podstawie: M. Gnoiński, Wpływ układu sieci drogowej na sprawy obronności Polski i NATO, prezentacja multimedialna, Wydział Zarządzania Uniwersytetu Łódzkiego, Tomaszów Mazowiecki, 4.06.2008 r. 
„w bezpośrednim sąsiedztwie trasy zaplanowano strefę ekonomiczną dla lotniska Łask, zlokalizowanego w gminie Buczek"27. Planowana budowa lotniska cargo będzie korelować z dogodnym połączeniem istniejacej sieci dróg. W tym przypadku droga S8 będzie swoistego rodzaju klamra spinająca cały układ drogowy regionu łódzkiego.

Transport integruje kraje i regiony, wpływając na ich aktywizację ekonomiczna, społeczną i polityczną. Jednak za jego przyczyna zwiększa się szkodliwe oddziaływanie na środowisko naturalne. Dlatego tak ważna jest w sektorze transportu polityka zrównoważonego rozwoju, gdyż prowadzona w sposób efektywny, skutecznie niweluje zagrożenia, wychodzi naprzeciw problemom ekologicznym, stara się nie dopuścić do zachwiania równowagi w środowisku naturalnym. Odpowiednio prowadzona - utrzymuje ład przestrzenny.

\subsection{Podstawowe elementy procesu inwestycyjnego}

Każda inwestycja infrastrukturalna, dla której przeprowadza się "postępowanie w sprawie oceny oddziaływania na środowisko (zwane dalej OOŚ), stanowi istotny element procesu inwestycyjnego"28. Niniejszy proces swoje uregulowania prawne opiera na prawie wspólnotowym, z uwzględnieniem dyrektyw Parlamentu Europejskiego, oraz na prawie krajowym w postaci ustaw dotyczących m.in. ochrony przyrody, ochrony środowiska naturalnego, prawa wodnego, prawa budowlanego, prawa o autostradach i drogach krajowych, a nawet o przygotowaniu finałowego turnieju Mistrzostw Europy w Piłce Nożnej UEFA $2012^{29}$. Zintegrowanie wszystkich wytycznych zawartych w wielu aktach prawnych nie było prostym zadaniem, jednakże usystematyzowanie i „stworzenie odpowiedniego narzędzia prawnego upraszczającego proces budowy dróg" ${ }^{\prime \prime 30}$ pozwoliło na sprawniejsze działania oraz przyspieszenie w postępowaniu dotyczącym procesu uzyskania zezwolenia na budowę drogi.

Zadania infrastrukturalne w postaci budowy dróg krajowych, realizowane w ramach procesu inwestycyjnego, charakteryzują się złożonością

27 Decyzja o środowiskowych uwarunkowaniach dla realizowanej budowy..., s. 4.

${ }^{28}$ Narodowe Strategiczne Ramy Odniesienia 2007-2013, Wytyczne w zakresie postępowania w sprawie oddziaływania na środowisko dla przedsięwzięć współfinansowanych z krajowych lub regionalnych programów operacyjnych, Minister Rozwoju Regionalnego, Warszawa, 5 maja 2009, s. 4.

29 Tamże, s. 5.

${ }^{30}$ A. Trembecka, Jedna decyzja zamiast pięciu, "Geodeta. Magazyn Geoinformacyjny" 2011, nr 11 (198), s. 39. 
i dużym stopniem skomplikowania. Są trudne do zrealizowania przede wszystkim z punktu widzenia inwestora. Ta sytuacja wynika stąd, że inwestycje drogowe prowadzone na tak dużą skalę są obciążone ryzykiem pojawienia się konfliktów społecznych z tytułu zbyt bliskiej lokalizacji w stosunku do terenów mieszkalnych oraz kontrowersjami spowodowanymi przechodzeniem inwestycji drogowych przez tereny cenne przyrodniczo. Aby w możliwie największym stopniu zniwelować potencjalne problemy, we wczesnym stadium przygotowania inwestycji drogowej przeprowadza się szerokie konsultacje społeczne, mające na celu przygotowanie mieszkańców na przyszłe zmiany w ich najbliższym otoczeniu. Tego rodzaju działania stanowią odzwierciedlenie zasady partycypacji publicznej w rozwiązywaniu problemów środowiskowych"31, w myśl której: „Organ administracji zapewnia możliwość udziału społeczeństwa, na zasadach i $w$ trybie określonych $w$ ustawie $z$ dnia 3 października 2008 r. o udostępnianiu informacji o środowisku i jego ochronie, udziale społeczeństwa w ochronie środowiska oraz o ocenach oddziaływania na środowisko [...]"32. Obowiazujaca od 2005 r. ustawa Prawo ochrony środowiska wprowadziła istotne zmiany, które dotyczą rodzaju i składu dokumentacji projektowej dla dróg krajowych ${ }^{33}$. Po zmianach funkcjonujący system charakteryzuje się następującymi etapami procesu inwestycyjnego:

„1. Dokumentacja studialna (DS):

a) studium techniczno-ekonomiczno-środowiskowe drogi krajowej (STEŚ) - etap I, etap II,

b) studium wykonalności inwestycji (SW).

2. Dokumentacja do decyzji o środowiskowych uwarunkowaniach zgody na realizację drogi krajowej (DŚU).

3. Dokumentacja programowa (DP):

a) koncepcja programowa drogi (KP),

b) projekt wstępny autostrady (PWA).

4. Dokumentacja do decyzji o ustaleniu lokalizacji drogi krajowej (DULD).

5. Dokumentacja budowlana (DB):

a) projekt budowlany inwestycji drogowej i jej elementów (PB),

${ }^{31}$ Ustawa z dn. 27 kwietnia 2001 r. Prawo ochrony środowiska, Dz.U. z 2001 r., nr 62, poz. 627 (rozdział 4, art. 218).

32 Tamże.

33 J. Bohatkiewicz (red.), Podręcznik dobrych praktyk wykonywania opracowań środowiskowych dla dróg krajowych, Biuro Ekspertyz i Projektów Budownictwa Komunikacyjnego EKKOM Sp. z o.o., Kraków 2007, s. 54. 
b) projekt wykonawczy inwestycji drogowej (PW),

c) dokumentacja projektowa (przetargowa) (DP)"134.

To oczywiście jeden z wie lu aspektów tego skomplikowanego postępowania. Przygotowanie pełnej dokumentacji oraz niezbędnych projektów, które narzucały przepisy Prawa ochrony środowiska, zajmowało inwestorowi mnóstwo czasu. W celu przyspieszenia działań dotyczących rozbudowy sieci dróg publicznych władza ustawodawcza zdecydowała się na wprowadzenie szczegółowych regulacji dotyczących liniowych inwestycji infrastrukturalnych. Jako pierwsza została uchwalona ustawa o autostradach płatnych ${ }^{35}$. Jednakże po okresie jej funkcjonowania okazało się, że potrzebne są zakrojone na szerszą skalę zmiany w kontekście planowania i realizowania zamierzeń infrastrukturalnych. $Z$ tego tytułu 10 kwietnia 2003 r. została uchwalona ustawa o szczególnych zasadach przygotowania i realizacji inwestycji w zakresie dróg krajowych ${ }^{36}$. Ten akt prawny potocznie został nazwany specustawa drogowa. Przyspieszenie rozwojowe związane z możliwościa pozyskania dodatkowych środków finansowych na inwestycje infrastrukturalne, na które duży nacisk kładzie Unia Europejska, sprawiło, że problemy prawno-geodezyjne pojawiające się $w$ toku realizacji inwestycji wymusiły zmiany również i w tej ustawie. 18 października 2006 r. długo oczekiwana nowela specustawy drogowej ${ }^{37}$ wprowadziła bardziej spektakularne rozwiązania legislacyjne i pozwoliła "sięgnąć do bardziej radykalnych środków w celu przyspieszenia procesu budowy dróg publicznych"38. Działanie to skutkowało znacznym skróceniem niezbędnych procedur w zakresie inwestycji infrastrukturalnych. Jednym z zagadnień, bardzo istotnych z punktu widzenia sprawnego przebiegu procesu inwestycyjnego, jest uzyskanie decyzji o lokalizacji drogi. Dzięki kolejnej nowelizacji, uchwalonej 25 lipca 2008 r., ustawa ta "spowodowała dalsze uproszczenie procedury poprzez wprowadzenie jednoetapowego postępowania ustalającego wszystkie warunki realizacji inwestycji drogowych"39. Dzięki zapisom prawnym, dwie dotychczasowe decyzje: o ustaleniu lokalizacji

34 Tamże.

35 Ustawa z dn. 27 października 1994 r. o autostradach płatnych oraz o Krajowym Funduszu Drogowym, Dz.U. z 2004 r., nr 256, poz. 2571.

${ }^{36}$ A. Kwartnik-Pruc, W pasie drogi, "Geodeta. Magazyn Geoinformacyjny” 2010, nr 2 (177), s. 56.

37 Ustawa z dn. 18 października 2006 r. o zmianie ustawy o szczególnych zasadach przygotowania i realizacji inwestycji w zakresie dróg krajowych oraz o zmianie niektórych innych ustaw, Dz.U. z 2006 r., nr 220, poz. 1601 z późn. zm.

${ }^{38}$ A. Trembecka, Jedna decyzja zamiast pięciu, s. 39.

${ }^{39}$ A. Kwartnik-Pruc, W pasie drogi, s. 56. 
oraz o pozwoleniu na budowę, zastapiono jedną decyzją o zezwoleniu na realizację inwestycji drogowej (ZRID). To skumulowanie odrębnych do tej pory postępowań administracyjnych skróciło tryb uzyskania niezbędnych pozwoleń. W wyniku uzyskania decyzji ZRID „następuje ustalenie lokalizacji inwestycji drogowej, wydzielenie geodezyjne i nabycie z mocy prawa terenu przeznaczonego pod inwestycje oraz zatwierdzenie projektu budowlanego"40. Dzięki wprowadzonym zmianom nieruchomości, które przeznaczone są pod pasy drogowe, automatycznie staja się własnością Skarbu Państwa lub własnością podległych terytorialnie jednostek samorządowych. Ustawa mówi: „Przejście własności nieruchomości pod drogi publiczne na rzecz Skarbu Państwa lub odpowiedniej jednostki samorządu terytorialnego następuje z mocy prawa na podstawie decyzji o zezwoleniu na realizację inwestycji drogowej, zwanej dalej decyzja ZRID"41. Można stwierdzić, że decyzja ZRID stanowi podstawę nabycia danego gruntu przez podmiot publicznoprawny. Do tej pory w tym obszarze dostępne kroki prawne, w postaci długotrwałych postępowań wywłaszczeniowych czy też zwykłej odmowy sprzedaży przez prawomocnych właścicieli gruntu, maksymalnie wydłużały proces inwestycyjny, stanowiąc trudna do przebycia barierę prawną i czasową w dalszym postępowaniu. Stwarzało to wiele problemów nie tylko dla inwestora, wykonawcy, ale przede wszystkim dla właścicieli gruntów, które przeznaczone były pod przebieg pasów drogowych. Cały proces wydłużał się w czasie, co niekorzystnie wpływało na wszystkie etapy postępowania inwestycyjnego. Oczywiście nawet najlepiej skonstruowana ustawa nie rozwiąże wszystkich problemów i nigdy nie będzie "lekiem na całe zło". Jednakże jej obecny kształt spowoduje znaczne uproszczenie dotychczasowej procedury. Kolejnym udogodnieniem z punktu widzenia własności i prawa użytkowania gruntu jest zapis przedmiotowej ustawy, który mówi: „Jeżeli na nieruchomości lub prawie użytkowania wieczystego tej nieruchomości zostały ustanowione ograniczone prawa rzeczowe, z dniem, w którym decyzja o zezwoleniu na realizację inwestycji drogowej stała się ostateczna, prawa te wygasaja"42. Daje to niemalże natychmiastową możliwość uzyskania danego gruntu pod inwestycję infrastrukturalną - decyzja ZRID określa "termin

40 Tamże.

41 Projekt założeń do projektu ustawy o zmianie ustawy o szczegółowych zasadach przygotowywania i realizacji inwestycji w zakresie dróg publicznych, Ministerstwo Infrastruktury, Warszawa, grudzień 2010, s. 2.

42 Ustawa z dn. 10 kwietnia 2003 r. o szczególnych zasadach przygotowania i realizacji inwestycji... (rozdział 3 , art. 12 , pkt 4c). 
wydania nieruchomości i opróżnienia lokali oraz innych pomieszczeń"43, który nie może być krótszy niż 120 dni od momentu, gdy przedmiotowa decyzja stanie się ostateczna. Wiele problemów zwiazanych jest również z prawidłowym opracowywaniem dokumentacji geodezyjnej dla terenów objętych inwestycjami drogowymi. Specustawa wprowadza możliwość nanoszenia zmian w ewidencji gruntów, a także w księgach wieczystych ${ }^{44}$.

Rozpatrując proces inwestycyjny z punktu widzenia obserwatora, który nie jest zaangażowany $w$ tok działań proceduralnych, można stwierdzić, że jest to postępowanie bardzo złożone, obwarowane dużą liczba przepisów prawnych, wymagający współpracy wielu instytucji publicznych, zaangażowania i determinacji głównego inwestora danego zamierzenia, ale również wzbudzający wiele emocji wśród potencjalnych beneficjentów, którzy z powodu wszczęcia wspomnianego procesu "skazani sa" na zmianę miejsca zamieszkania i trudny do zaakceptowania proces wywłaszczeniowy.

W procesie inwestycyjnym należy brać pod uwagę również integralne z wyżej omówionymi przepisy prawa budowlanego. Prawa i obowiazki nałożone na uczestników procesu budowlanego określaja, kto i w jakim zakresie bierze w nim udział. Są to:

1. Inwestor.

2. Inspektor nadzoru inwestorskiego.

3. Projektant.

4. Kierownik budowy lub kierownik robót ${ }^{45}$.

Każdy z nich, sprawując samodzielną funkcję, ma określone obowiązki, których wypełnianie gwarantuje sprawny przebieg procesu budowlanego podczas realizacji danego zadania inwestycyjnego. Inwestor ma za zadanie „zorganizowanie procesu budowy z uwzględnieniem zawartych $w$ przepisach zasad bezpieczeństwa i ochrony zdrowia"46, a w szczególności sporządzenie planu BIOZ ${ }^{47}$. W przypadku, gdy istnieje duży stopień skomplikowania robót budowlanych, obowiazkiem inwestora jest "sprawowanie nadzoru przez osoby

43 Tamże, rozdział 3, art. 16, pkt 2.

${ }^{44}$ Opracowanie na podstawie: A. Kwartnik-Pruc, W pasie drogi, s. 58.

${ }^{45}$ Ustawa z dn. 7 lipca 1994 r. Prawo budowlane... (rozdział 3, art. 17).

46 Tamże, rozdział 3, art. 18, pkt 1.

47 Plan BIOZ - plan bezpieczeństwa i ochrony zdrowia. Jest to najważniejszy dokument, który chroni zdrowie pracowników zatrudnionych na danej budowie, zawiera niezbędne zasady postępowania w zakresie bezpieczeństwa i ochrony zdrowia. Za: www.bioz.pl [z dn. 30.03.2012]. 
o odpowiednich kwalifikacjach zawodowych"48 poprzez ustanowienie inspektora nadzoru na danej budowie, który zapewnia w takim przypadku nadzór autorski. Opracowaniem projektu budowlanego „w sposób zgodny z ustaleniami zgody urbanistycznej oraz ustaleniami określonymi w decyzji o środowiskowych uwarunkowaniach"49 zajmuje się projektant. Odpowiada on za sprawdzenie projektu architektonicznego pod kątem zgodności z przepisami techniczno-budowlanymi przez osobę z nieograniczonymi uprawnieniami w odpowiedniej specjalności (budowlanej, sanitarnej, elektrycznej i innych). Niezwykle ważna osobą w procesie budowlanym jest kierownik budowy. Przejmuje on na podstawie protokołu teren budowy wraz ze znajdujacymi się w jego obrębie istniejącymi obiektami, wytycza geodezyjnie i organizuje budowę, sumiennie prowadzi cała dokumentację w postaci dziennika budowy, koordynuje i nadzoruje wszelkie działania, które maja miejsce na jej terenie.

W niniejszym rozdziale analizowanym zamierzeniem inwestycyjnym jest budowa drogi S8. Na terenie województwa łódzkiego inwestycja ta została podzielona na dziewięć odcinków. To pokazuje, że proces inwestycyjny w tym przypadku jest niezwykle skomplikowany i wymaga ustalenia etapowości działania. Takie postępowanie ułatwiło znalezienie wykonawców, a zapewne także przyspieszyło otrzymanie wszystkich niezbędnych pozwoleń związanych z procesem inwestycyjnym. Tabela 19 pokazuje zestawienie wszystkich odcinków drogi S8 na obszarze województwa łódzkiego.

Tabela 19. Zestawienie odcinków S8 w województwie łódzkim z uwzględnieniem węzłów i obiektów infrastrukturalnych

\begin{tabular}{|c|l|c|l|}
\hline $\begin{array}{c}\mathrm{Nr} \\
\text { odcinka }\end{array}$ & Nazwa węzła & $\begin{array}{c}\text { Długość } \\
\text { odcinka (km) }\end{array}$ & \multicolumn{1}{|c|}{ Obiekty infrastruktury technicznej } \\
\hline 1 & Wieluń & 2,0 & 2 obiekty mostowe, 1 obiekt środowiskowy \\
\hline 2 & Złoczew & 19,0 & $\begin{array}{l}16 \text { obiektów mostowych, 4 obiekty środowi- } \\
\text { skowe, MOP, OUS }\end{array}$ \\
\hline 3 & - & 6,0 & 3 obiekty mostowe, 1 obiekt środowiskowy \\
\hline 4 & Sieradz-Południe & 19,6 & $\begin{array}{l}18 \text { obiekty mostowe, 1 obiekt środowisko- } \\
\text { wy, MOP }\end{array}$ \\
\hline
\end{tabular}

48 Ustawa z dn. 7 lipca 1994 r. Prawo budowlane... (rozdział 3, art. 18, pkt 1, ppkt 5).

49 Tamże, rozdział 3, art. 20, pkt 1, ppkt 1. 
Tab. 19 (cd.)

\begin{tabular}{|c|l|c|l|}
\hline $\begin{array}{c}\mathrm{Nr} \\
\text { odcinka }\end{array}$ & \multicolumn{1}{|c|}{ Nazwa węzła } & $\begin{array}{c}\text { Długość } \\
\text { odcinka }(\mathrm{km})\end{array}$ & \multicolumn{1}{|c|}{ Obiekty infrastruktury technicznej } \\
\hline 5 & $\begin{array}{l}\text { Sieradz-Wschód, } \\
\text { Zduńska Wola, } \\
\text { Karsznice }\end{array}$ & 33,6 & $\begin{array}{l}33 \text { obiekty mostowe, 2 obiekt środowisko- } \\
\text { wy, 2 MOP }\end{array}$ \\
\hline 6 & Łask & 9,2 & 11 obiekty mostowe, 3 obiekt środowiskowy \\
\hline 7 & Róża & 3,6 & 2 obiekty mostowe, 1 obiekt środowiskowy \\
\hline 8 & Pabianice, Rzgów & 19,4 & $\begin{array}{l}15 \text { obiekty mostowe, 3 obiekt środowisko- } \\
\text { wy, MOP, PRO }\end{array}$ \\
\hline 9 & Łódź-Południe & 1,3 & 4 obiekty mostowe, 1 obiekt środowiskowy \\
\hline
\end{tabular}

Źródło: opracowanie własne.

Dla usprawnienia przebiegu procesu inwestycyjnego, umowy na budowę podpisywane były oddzielnie na poszczególne odcinki. Umowę na odcinek $\mathrm{nr} 1$ podpisano latem $2011 \mathrm{r}$. W październiku zostały zawarte umowy na kolejne odcinki: 6, 7, 8 i 9. Ostatnie umowy na budowę czterech odcinków (2, 3, 4 i 5) zostały podpisane w styczniu 2012 r. Obecnie trwaja prace na wszystkich odcinkach. Stan ich zaawansowania jest różny. Realizacja umów ma potrwać 27 miesięcy od daty ich zawarcia. Planowane zakończenie budowy przewiduje się na kwiecieńmaj $2014 r^{50} \mathrm{~W}$ sumie na terenie województwa łódzkiego powstanie ponad $100 \mathrm{~km}$ nowej trasy ekspresowej od miejscowości Walichnowy do węzła Łódź-Południe.

Droga ekspresowa S8 to obiekt liniowy o skomplikowanym układzie. Podstawowym elementem jest pas drogowy czyli "wydzielony liniami rozgraniczającymi pas terenu [...] nieobsługujący przyległego terenu, przeznaczony do ruchu pojazdów z dwiema trwale rozdzielonymi jezdniami jednokierunkowymi, wielopoziomowymi skrzyżowaniami, wraz z leżącymi w jego obrębie obiektami inżynierskimi oraz [...] drogami dojazdowymi, drzewami i krzewami oraz urządzeniami technicznymi związanymi z prowadzeniem i zabezpieczeniem ruchu"51. Integralnym elementem drogi ekspresowej są węzły. W przypadku przebiegu trasy drogi S8 na terenie województwa łódzkiego zaprojektowano węzły typu WA, na których „nie występuje przecinanie torów jazdy, a relacje skrętne są realizowane tylko jako manewry włączania, wyłączania i przeplatania się potoków ruchu"52.

50 Opracowanie własne na podstawie: www.gddkia.pl [z dn. 30.03.2012].

${ }^{51}$ Dokumentacja do wydania opinii dla wniosku o wydanie decyzji..., s. 9.

52 J. Bohatkiewicz (red.), Podręcznik dobrych praktyk..., s. 33. 


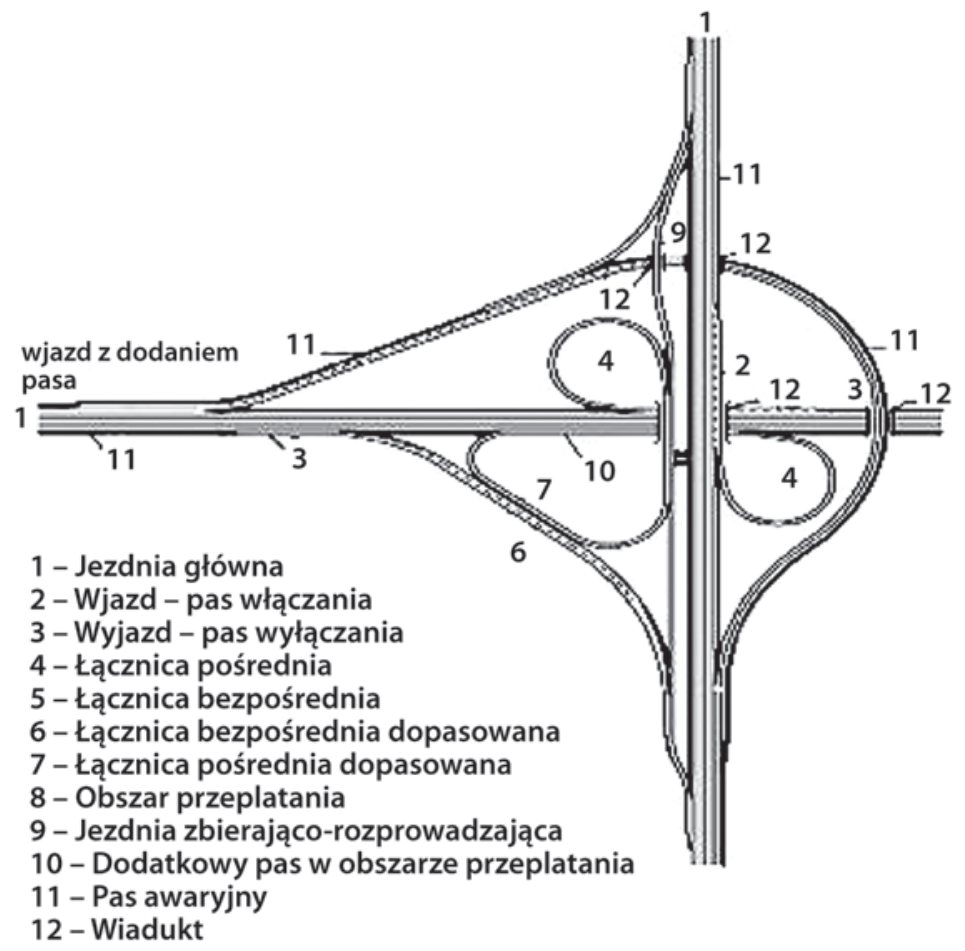

Rysunek 18. Elementy węzła drogowego

Źródło: J. Bohatkiewicz (red.), Podręcznik dobrych praktyk wykonywania opracowań środowiskowych dla dróg krajowych, Biuro Ekspertyz i Projektów

Budownictwa Komunikacyjnego EKKOM Sp. z o.o., Kraków 2007, s. 34

Na rys. 18 zaprezentowano schemat przykładowego węzła, który w sposób bezkolizyjny umożliwia zmianę kierunku jazdy. Oprócz węzłów w pasie drogowym można spotkać różnego rodzaju obiekty inżynierskie, stanowiące techniczne wyposażenie dróg. Należą do nich takie obiekty, jak ${ }^{53}$ :

- MOP - miejsce obsługi podróżnych - jest to teren wydzielony w pasie drogowym, przeznaczony na miejsca postojowe oraz wszelkiego rodzaju urządzenia służące zaspokajaniu potrzeb użytkowników drogi,

- OUS - obwód utrzymania drogi - to teren, na którym zlokalizowano obiekty stanowiące zaplecze techniczne i osobowe dla kompleksowej obsługi technicznej danego odcinka drogi,

- urządzenia odwadniające oraz odprowadzajace wodę,

53 Opracowanie własne za: tamże, s. 14-35. 


\section{- urządzenia oświetleniowe,}

- urządzenia techniczne drogi w postaci barier, osłon energochłonnych, osłon przeciwwietrznych i przeciwśnieżnych,

\section{- ekrany akustyczne,}

- różnego typu przejścia dla zwierząt.

Wymienione obiekty i urządzenia techniczne to tylko wycinek spośród wielu integralnych elementów, które w całości tworzą liniowe zamierzenie inwestycyjne $w$ postaci drogi ekspresowej. Nowoczesna technologia budowy i ciagły wzrost zapotrzebowania społeczeństwa na dogodne połączenia komunikacyjne powoduja, że w środowisku naturalnym na terenach zajętych pod budowę wciąż zachodzą zmiany. Ich charakter warunkuje stopień jego degradacji. Dlatego tak ważnym zagadnieniem jest ochrona przyrody w drogownictwie, stając się kluczowym elementem procesu inwestycyjnego. Umiejętne pogodzenie, z jednej strony, potrzeb rozwoju sieci korytarzy drogowych, z drugiej - niwelowania skutków ingerencji w środowisko naturalne jest konieczne z punktu widzenia harmonizacji przepisów krajowych i unijnych. Daje to możliwość pełnego wykorzystania wszystkich dostępnych narzędzi prawnych $w$ celu poprawy procedur ochrony środowiska. Niezwykle ważne jest, aby cały proces inwestycyjny współgrał z zasadami zrównoważonego rozwoju. Nowoczesna infrastruktura komunikacyjna jest znakiem naszych czasów.

\subsection{Bariery rozwoju regionalnego z szerszej perspektywy}

W sektorze publicznym, a w szczególności w dziedzinie inwestycji infrastrukturalnych w ostatnich latach polska gospodarka poczyniła niemalże milowe kroki na drodze rozwoju ekonomicznego i intelektualnego. Duża poprawę widać również w sferze innowacyjnych rozwiązań technologicznych. Jednakże zagadnienia związane z postępem gospodarczym niosą zagrożenia i bariery, których pokonanie będzie priorytetowym zadaniem obecnego i zapewne jeszcze przyszłych rządów w naszym kraju. Sięganie do tak wysokiego szczebla nie powinno dziwić, gdyż bariery uwidocznione poniżej mają charakter systemowy, a dotyczą przede wszystkim zagadnień prawno-proceduralnych oraz organizacyjnych w obrębie sektora publicznego. Pochylenie się nad tymi zagadnieniami może choć w niewielkim stopniu unaoczni skalę niedociągnięć prawnych i komplikacji proceduralnych czy też doboru niekompetentnych kadr oraz niedostatku fachowców legitymujących się 
odpowiednimi uprawnieniami. Jest to ważne zagadnienie zarówno dla prawodawców, jak i zwykłych obywateli, którzy z przedmiotowymi barierami stykaja się każdego dnia.

Uchwała Rady Ministrów nr 163 z dnia 25 września 2007 w sprawie ustanowienia programu wieloletniego pod nazwa "Program Budowy Dróg Krajowych na lata 2008-2012" otworzyła szerokie perspektywy dla rozwoju infrastruktury drogowej w Polsce. Taka sprzyjajaca sytuacja w powiązaniu z tendencjami, jakie zaczęły dominować w naszym kraju po przystapieniu Polski do Unii Europejskiej, nie miała miejsca już od bardzo dawna. Co więcej, zwycięska batalia o organizację Mistrzostw Europy w piłce nożnej sprawiła, że Polska znalazła się w gronie państw organizujących EURO 2012. Stało się to dodatkowym impulsem do działania na rzecz rozwoju państwa polskiego. Wszystkie te procesy zaczęły znacząco stymulować rozwój gospodarczy, a w szczególności pobudziły potencjał rozwojowy i inwestycyjny, dzięki któremu dostrzeżono braki i ograniczenia w istniejącym systemie infrastruktury drogowej. Polska po 50 latach zapóźnień rozwojowych dostała "niebywała szansę przyspieszenia rozwojowego i nadrobienia opóźnień cywilizacyjnych w stosunku do czołówki rozwiniętych krajów Europy i świata"54. Zaprezentowane tu omówienie zjawisk i zagadnień, które stanowią bariery rozwojowe będzie zatem dopełnieniem obrazu trwale związanego z procesem inwestycyjnym z dziedziny infrastruktury technicznej.

Aby sprostać wszystkim wyzwaniom, które niesie ze soba przyspieszenie rozwojowe i postęp, należy przede wszystkim dążyć do sytuacji, w której środki na finansowanie przedsięwzięć infrastrukturalnych będą w skuteczny sposób pozyskiwane, a następnie odpowiednio alokowane. W przeciwnym razie sytuacja ta stanie się poważną barierą rozwoju regionalnego. Obecnie najbardziej znanymi źródłami pozyskania środków na finansowanie inwestycji infrastrukturalnych sa fundusze europejskie oraz budżet państwa. Jednakże poważnym błędem jest zaniechanie sięgania po inne możliwości. „Do źródeł tych należą kredyty od międzynarodowych instytucji finansowych, emisje obligacji czy partnerstwo publiczno-prywatne"55. Współfinansowanie przedsięwzięć infrastrukturalnych przez Unię Europejską wiąże się z dużym

${ }^{54}$ Z. Ofiarski (red.), Współpraca dla rozwoju. Samorząd terytorialny jako reżyser lokalnego rozwoju. Polityka społeczna jako instrument rozwoju, "Zeszyty Naukowe. Wyższa Szkoła Administracji Publicznej w Szczecinie" 2008, nr 1, s. 5.

${ }^{55}$ Fundacja FOR, PricewaterhouseCoopers, Wardyński i Wspólnicy, 4CFuture, Którędy droga? Raport o tym, jak odblokować inwestycje drogowe w Polsce, Warszawa 2009, s. 57. 
wyzwaniem finansowym dla polskich instytucji zaangażowanych w wydatkowanie budżetu. Aby móc w pełni korzystać z dostępnych funduszy pomocowych i strukturalnych przeznaczonych na celowy rozwój infrastruktury drogowej w Polsce, instytucje te (w ramach budżetu państwa) zmuszone sa gromadzić duże ilości środków krajowych, które mają być przekazane "do budżetu UE w postaci składek państw członkowskich, czyli tzw. środków własnych"56. Istotnym zagadnieniem jest efektywne wykorzystanie środków już pozyskanych. Najdogodniejsza jest sytuacja, gdy realizacja danego projektu inwestycyjnego jest odpowiednio skorelowana ze sposobem jego finansowania. "W Polsce dostosowanie sposobu finansowania do charakterystyki projektu wciąż należy do rzadkości"57. Struktura wydatków związana z przedsięwzięciami infrastrukturalnymi pokazuje, że zdecydowanie więcej środków pieniężnych przeznacza się na budowę nowych dróg krajowych (to pozytywna tendencja) oraz w nieco mniejszym stopniu na drogi powiatowe i gminne znajdujące się w zarządzie jednostek terytorialnych. "Na budowę i rozbudowę dróg przeznacza się dziewięć razy więcej środków niż na remonty"58. To pokazuje skalę tego zjawiska. A przecież odpowiednio przeprowadzone, czasami drobne remonty lub modernizacja danej drogi w zdecydowanie większym stopniu przyniosłyby korzyści dla użytkowników dróg oraz dla zarządcy. Nie należy nastawiać się tylko na budowę nowych połączeń transportowych. Ważna jest też dbałość o istniejąca infrastrukturę, która z braku alternatywy transportowej przez lata była „rozjeżdżana". Potrzeba tutaj rozwagi, rozsądku, a czasami zwykłej mądrości życiowej. Zmiana nastawienia i złych tendencji w polityce rozwoju to sposób na uzyskanie lepszych efektów końcowych, co w tym przypadku przekłada się na lepsze wykorzystanie środków finansowych.

Z pozyskaniem środków finansowych i ich wykorzystaniem złączony jest problem „braku realnej alternatywy dla budżetowego finansowania inwestycji"59. Dotyczy to przede wszystkim swobodnego korzystania z możliwości, jakie daje partnerstwo publiczno-prywatne (PPP). Część przepisów prawa dotycząca tej sfery jest po prostu martwa! Spowodowane to jest niespójnościa pomiędzy ustawą Prawo zamówień publicznych a przepisami dotyczącymi PPP. W przypadku

${ }^{56}$ Budżet Unii Europejskiej, broszura informacyjna Urzędu Komitetu Integracji Europejskiej, 2009, s. 8.

57 Fundacja FOR, PricewaterhouseCoopers, Wardyński i Wspólnicy, 4CFuture, Którędy droga..., s. 57.

58 Tamże.

59 Tamże, s. 48. 
realizacji zamierzeń inwestycyjnych, takich jak budowa płatnych autostrad, sytuacja nie wygląda najgorzej - partnerzy prywatni partycypuja w procesie współfinansowania budowy, mając swój udział w całym przedsięwzięciu określony przepisami ustawy o autostradach płatnych. Jednakże przyglądając się sytuacji w zakresie innych dróg publicznych (gminnych, powiatowych, wojewódzkich czy też krajowych), próżno szukać wzajemnej korelacji partnerów z sektora prywatnego i publicznego. Współpraca na tym polu jest utrudniona niespójnością w przepisach o koncesjach na roboty budowlane oraz pojawiającymi się ograniczeniami, jeśli chodzi o rodzaje przedsięwzięć, które mogłyby być realizowane na zasadach i w trybie ustawy o PPP. Z tym obszarem zagadnień powiazana jest instytucja zamówień publicznych. Obecne prawo nakładając wymóg "najniższej ceny” i kryteriów dodatkowych, tak naprawdę bierze pod uwagę tylko ten pierwszy. Przepis mówi: „Zamawiający udziela zamówienia wykonawcy, który zaoferował najniższą cenę" 60 . To sformułowanie zamyka drogę wielu przedsiębiorcom. Z rynku zostaja wyeliminowani oferenci, których produkt lub usługa spełnia wysokie wymagania jakościowe i materiałowe, posiada odpowiednie "parametry techniczne, charakteryzuje się zastosowaniem najlepszych dostępnych technologii w zakresie oddziaływania na środowisko $[\ldots]^{\prime \prime 61}$, czego konsekwencja jest cena, która kształtuje się na wyższym poziomie. Sporządzenie specyfikacji istotnych warunków zamówienia $^{62}$ to żmudne gromadzenie dokumentacji, która wymaga spełnienia co najmniej 17 wymogów. Oprócz tego niezbędna jest dokumentacja projektowa, specyfikacja techniczna, dokument odbioru robót budowlanych, a w określonych warunkach - sporządzenie programu funkcjonalno-użytkowego ${ }^{63}$. Wszystkie te działania, mimo tak ogromnego zaangażowania i wkładu pracy oraz wiedzy, nie sa gwarantem otrzymania zlecenia realizacji danego zamierzenia. Dlaczego nie dążymy do uproszczenia procedur? W tym zakresie ustawodawca w naszym kraju ma jeszcze wiele do zrobienia.

Kolejną bariera proceduralną i poważnym ograniczeniem na drodze rozwoju regionalnego poprzez rozwój sektora transportu jest brak planów zagospodarowania przestrzennego miast i gmin. $Z$ tą bolączką boryka się wiele jednostek samorządu terytorialnego. Wiąże się

60 Ustawa z dn. 29 stycznia 2004 r. Prawo zamówień publicznych, Dz.U. z 2007 r., nr 223, poz. 1655 oraz z 2008 r., nr 171, poz. 1058 (rozdział 3, oddział 6, art. 72, pkt 2).

61 Tamże, rozdział 4, art. 91, pkt 2.

62 Tamże, dział II, rozdział 2, art. 36, pkt 1.

${ }^{63}$ Tamże, dział II, rozdział 2, art. 31, pkt 2. 
to z długa i kosztowna procedurą uchwalenia planu zagospodarowania, począwszy od uchwały gminnej o przystapieniu do sporządzania planu, poprzez ogłoszenie tego zamiaru w prasie, składanie wniosków do planu, wyłożenie projektu planu do publicznej wiadomości - to tylko wybrane kroki z bardzo czasochłonnej procedury. Ogłoszenie planu zagospodarowania przestrzennego $\mathrm{w}$ praktyce przeciąga się i średnio trwa około jednego roku. Niekiedy - jeśli opracowywany jest projekt przestrzeni publicznej charakteryzujący się dużą zawiłościa, obszernościa dokumentacji - procedura trwa znacznie dłużej. Na skrócenie tego okresu nie pozwala skomplikowana procedura, która, niestety, przyczynia się do złego wizerunku władz samorządowych określanych mianem opieszałych i źle zarządzających publicznym dobrem. Konsekwencja jest uchwalanie planów zagospodarowań we fragmentach, tylko dla pewnych obszarów, dla jednej dzielnicy miasta lub kilku wsi w danej gminie. Poważnym niedopatrzeniem jest brak korelacji między tworzonymi fragmentami lub brak spójności z ogólną koncepcją zagospodarowania przestrzeni w odniesieniu do województwa lub regionu.

Bariera ograniczająca rozwój regionu jest niezadowalający stan istniejącej infrastruktury drogowej, a co za tym idzie, pogorszenie przepustowości głównych sieci transportowych $w$ postaci dróg. Ten aspekt techniczny utrudnia optymalny rozwój gospodarczy i społeczny nie tylko danego regionu, ale nawet kraju. Pogarsza się w ten sposób konkurencyjność polskich przedsiębiorstw, które bez dodatkowego wsparcia ze strony władz szczebla wojewódzkiego czy też lokalnych jednostek samorządu terytorialnego nie moga poradzić sobie w dzisiejszej rzeczywistości gospodarczej. Słaba dostępność i przepustowość dróg wpływa na spadek efektywności i znacząco podnosi koszty prowadzenia działalności gospodarczej. Jednostki samorządu terytorialnego, które dbaja o swój wizerunek wśród obywateli, doskonale zdając sobie sprawę z tego typu uwarunkowań, potrafia wykorzystać daną sytuację. Dlatego też inwestycje w infrastrukturę (jeśli już dojdzie do takiego zamierzenia) sa spektakularne wśród samorządów ${ }^{64}$.

Wspomniany aspekt techniczny ma jeszcze jedno oblicze, które tutaj warto wyeksponować. „Poważniejszym ograniczeniem może być niedobór na rynku polskim osób posiadających odpowiednie uprawnienia budowlane w specjalności drogowej i mostowej"65.

64 "Gazeta Prawna", 13.07.2011, nr 134.

${ }^{65}$ Fundacja FOR, PricewaterhouseCoopers, Wardyński i Wspólnicy, 4CFuture, Którędy droga..., s. 46. 
Z problemem tym polska gospodarka boryka się już od kilku lat. Stale malejąca liczba studentów na kierunkach inżynieryjnych i technicznych jest przyczyna owego niedoboru. Pewnym ułatwieniem i zachęta dla przyszłych studentów jest wprowadzenie tzw. kierunków zamawianych ${ }^{66}$ na uczelniach wyższych i politechnikach. Niedobór kadry o odpowiednich kwalifikacjach skutkuje również marnym i niedoskonałym zarządzaniem w sektorze publicznym. Stąd propozycja wprowadzenia nowej koncepcji zarządzania do sektora publicznego - New Public Management.

Przedstawione bolączki, z którymi na co dzień borykają się uczestnicy życia publicznego, a także omówione bariery rozwoju daja obraz skali problemów. Zapewne można byłoby przedstawić jeszcze wiele innych zagadnień, które maja pośredni lub bezpośredni wpływ na rzeczywistość ekonomiczną i gospodarczą. Niespójność przepisów prawa, brak harmonizacji między pokrewnymi dziedzinami, zbyt skomplikowane procedury czy też martwe przepisy - skutecznie ograniczaja szanse na rozwój regionalny. $Z$ takiej perspektywy widać, że nakładające się na siebie problemy organizacyjne, prawne i proceduralne powinny być jak najszybciej wyeliminowane z przestrzeni publicznej. Próba poprawienia błędów będzie pierwszym krokiem na drodze wiodącej w dobrym kierunku.

\subsection{Wnioski i rekomendacje}

Wypadkową wszystkich rozważań zawartych w niniejszym rozdziale oraz próbę zarekomendowania odpowiednich działań stanowić będa przyjęte ustalenia i wnioski badawcze. Aby je sformułować, stawiano pytania o to, czy opisywane inwestycje infrastrukturalne dla regionu łódzkiego:

- są ważne?

- sa potrzebne?

- czy wniosa coś nowego?

- jaki wpływ będą miały w nieodległej przyszłości na obraz życia w jego różnych aspektach?

${ }^{66}$ Kierunek zamawiany - kierunek studiów technicznych, który znalazł się na liście kierunków wybranych przez Ministerstwo Nauki i Szkolnictwa Wyższego jako szczególnie istotny dla gospodarki kraju. Studenci otrzymuja wysokie stypendia za wyniki w nauce, co korzystnie wpływa na ich postawę i determinuje przyszłe kroki na drodze kariery zawodowej. Program stypendiów jest współfinansowany przez UE. 
- czy w nas, mieszkańcach tego regionu, wzbudzą chęć do rozwoju, dadza impuls kreatywności?

- a może wzbudzą niechęć, ponieważ niszczeje środowisko naturalne, wzmaga się hałas, kurczy się miejsce enklaw przyrodniczych?

- czy dadza możliwość rozwoju młodego pokolenia?

- czy przybliża nas do nowoczesnej Europy?

Tych pytań jest wiele, a wszystkie sa istotne i trzeba dla nich poszukać racjonalnych odpowiedzi. Niektóre z nich same nasunęły się podczas procesu badawczego. Stanowczo trzeba potwierdzić, że inwestycje infrastrukturalne maja zdecydowanie pozytywny wpływ na rozwój regionu. Szukanie sytuacji stwarzających możliwości przeprowadzenia sprawnego procesu inwestycyjnego dla zamierzeń infrastrukturalnych, a także sprzyjanie takim działaniom, powinno być najwyższym nakazem dla establishmentu ze wszystkich poziomów władzy naszego państwa. Takie są tendencje rozwojowe światowej gospodarki, potrzeby naszego kraju, takie są oczekiwania mieszkańców, nie warto być w opozycji.

W niniejszym rozdziale omawiane były dwie duże, o zupełnie innym charakterze, inwestycje infrastrukturalne. Pierwsza z nich to budowa drogi ekspresowej S8. Jako druga przedstawiono projekt budowy cywilnego lotniska cargo w gminie Łask. Obie te inwestycje tak różniące się od siebie, maja wiele cech wspólnych, wzajemnie się przenikających i oddziałujących na siebie.

\section{Droga Ekspresowa $\mathbf{5 8}$}

Analiza inwestycji drogowej na przykładzie budowy drogi S8 to praca na żywym organizmie. Postęp prac budowlanych oraz wszystkie dostępne dokumenty powiązane z procesem inwestycyjnym, a także relacje osób bezpośrednio związanych z tą tematyka dały pełny obraz tej ważnej inwestycji. W namacalny sposób można było zobaczyć, jak proces inwestycyjny przebiega w przestrzeni społecznej i gospodarczej. Siłą rzeczy można było skupić się na pewnym wycinku, fragmentarycznie ujmującym całość tego zagadnienia. Informacje, które pojawiały się w toku badań, musiały być przepuszczone przez swego rodzaju filtr, który jednak oddawał pełnię tematyki, pozwalał na posegregowanie i gradację najważniejszych kwestii.

Droga S8 to jeden z bardzo wielu elementów infrastruktury drogowej w Polsce, której bolączką jest brak autostrad oraz niedostateczny stan techniczny. Budowa tej trasy na pewno zmieni ten stan rzeczy. Wydatnie 
skomunikuje nie tylko obszar województwa łódzkiego, ale wykraczając poza jego granice, przyczyni się do poprawy sytuacji także $w$ regionie wielkopolskim oraz na Mazowszu. Droga S8 stanowi sieć powiązań infrastrukturalnych działających jak naczynia połączone. W momencie oddania do ruchu odciąży inne drogi krajowe, pełniące obecnie funkcję najważniejszych szlaków transportowych województwa. Widocznym tego skutkiem, szczególnie z punktu widzenia każdego kierowcy, będzie zmniejszenie natężenia ruchu na drogach lokalnych (gminnych i powiatowych), a także poprawa bezpieczeństwa ruchu - mniej samochodów poruszających się po drogach to mniej wypadków, stłuczek, potrąceń przechodniów i wielu innych zdarzeń drogowych. Kierowcy także będą cieszyć się z większej dostępności danego obszaru oraz lepszego stanu nawierzchni dróg o mniejszym znaczeniu - ruch kołowy przeniesie się głównie na drogi krajowe, ekspresowe i autostrady, odciążając w ten sposób centra miast i miasteczek. Czas przejazdu z jednego punktu do celu podróży ulegnie znacznemu skróceniu. Przeniesie się to bezpośrednio na ilość spalanego paliwa, co spowoduje zmniejszenie kosztów transportu. Jest to ważne zagadnienie nie tylko dla pojedynczego użytkownika drogi. Tę kwestię należy także rozpatrywać w kategoriach niemalże globalnych. Koszty eksploatacji pojazdów przekładają się na łączne koszty eksploatacji wszystkich pojazdów poruszających się po polskich drogach. Ich skala jest znaczna, zależy głównie od rodzaju danego pojazdu (osobowe, ciężarowe, autobusy), stanu nawierzchni danej drogi i jej ukształtowania oraz średniej prędkości, jaką rozwijaja pojazdy. Koszty transportu w takim przypadku szacuje się w miliardach złotych. Obniżenie wydatków o takiej skali choćby tylko o 10\% (a takie przyjmuje się szacunki) ${ }^{67}$ jest wymierną korzyścią dla państwa, władz lokalnych, każdego przedsiębiorcy i mieszkańca Polski. Inwestowanie w infrastrukturę drogowa przynosi zatem korzyści ekonomiczne i gospodarcze w wielu wymiarach. Budowa drogi S8 oraz powstanie wielu podobnych połączeń drogowych ma jeszcze jeden ważny aspekt. Jest to dążenie do zrównoważonego rozwoju. To zagadnienie uosabia przede wszystkim odpowiednie spojrzenie na sprawy ekologii, związanej z tym ochrony środowiska i takiego postępowania człowieka, aby przyszłe pokolenia mogły cieszyć się i egzystować w czystym środowisku naturalnym, niezniszczonym przez nieroztropną gospodarkę. Wszelkiego rodzaju koszty środowiskowe, wynikajace z użytkowania dróg, to koszty zanieczyszczenia środowiska naturalnego, ujawniające się jako straty

${ }^{67}$ Fundacja FOR, PricewaterhouseCoopers, Wardyński i Wspólnicy, 4CFuture, Którędy droga..., s. 22. 
materialne. Druga kategorią kosztów środowiskowych jest możliwy uszczerbek zdrowia użytkowników dróg, polegający na ujemnym wpływie na zdrowie ludzkie takich szkodliwych substancji, jak tlenek węgla, tlenki azotu, siarki czy też węglowodory. Wszystkie te związki chemiczne sa główną składową gazów spalinowych, będących efektem spalania etylin w silnikach pojazdów poruszających się po drogach. I choć w poziomie ogólnego zanieczyszczenia atmosferycznego motoryzacja jako dziedzina gospodarki (w porównaniu z innymi sektorami, takimi jak przemysł chemiczny, metalurgiczny, rafineryjny, składowanie odpadów i wydobycie surowców naturalnych) ma stosunkowo niewielki udział procentowy, warto pokusić się o jego dalsze obniżenie. Będzie to miało swoje odzwierciedlenie $w$ działaniach ekologicznych zmierzających do poprawy życia ludzi, zwierząt i roślin. Żyjemy przecież w "globalnej wiosce". Stąd też bierze się troska o przyszłe poczynania. Nie bez przyczyny inwestycje infrastrukturalne, zanim powstana na etapie procesu inwestycyjnego, analizowane są pod wieloma względami. Szczególne miejsce zajmuje tutaj właśnie ochrona przyrody. Opracowania w postaci decyzji środowiskowej pokazuja podejście do tego zagadnienia z punktu widzenia procedur prawnych, które maja na względzie przede wszystkim odpowiednie uregulowania idące w kierunku proekologicznym, zgodnym z założeniami zrównoważonego rozwoju.

$\mathrm{Na}$ podstawie analizy powyższych zagadnień można stwierdzić, że inwestycja infrastrukturalna w postaci drogi S8 jest bardzo ważna i potrzebna dla regionu łódzkiego. O wybudowanie tej drogi zabiegały liczne środowiska oraz sprzyjał temu projektowi minister infrastruktury Cezary Grabarczyk. Realizacja tego przedsięwzięcia daje szansę na przyspieszenie rozwoju, jest jego katalizatorem, który poprzez wniesienie nowych wartości potrafi zmienić otaczające nas środowisko.

\section{Lotnisko cargo w Kasku}

Zagadnienie powstania i budowy cywilnego lotniska pod Łaskiem wygląda nieco inaczej, niż to miało miejsce w przypadku drogi ekspresowej. W odróżnieniu od analizowanej wyżej inwestycji, której proces budowy postępuje obecnie na naszych oczach, budowa lotniska cargo jeszcze się nie rozpoczęła lub też, biorąc pod uwagę wszystkie wysiłki włożone w jego realizację przez Spółkę "Lotnisko Łask", jest na bardzo wstępnym etapie. Omawianie tej inwestycji z zakresu infrastruktury lotniczej to wirtualna droga, która (czego doświadczyła autorka) prowadzi niekiedy do zaskakujących konkluzji, zmierzających do sformułowania 
apelu lub petycji. Praca nad zagadnieniami oscylującymi wokół tego zamierzenia infrastrukturalnego wymagała dalekosiężnego spojrzenia w przyszłość, kreatywności w wyciąganiu wniosków, umiejętności połączenia faktów, które dopiero maja szansę zaistnieć. Cywilne lotnisko cargo, które na drodze synergicznej wymiany działań z istniejącym i funkcjonującym w strukturach NATO lotniskiem wojskowym w Łasku mogłoby świetnie egzystować i stanowić element logistycznego systemu transportowego regionu łódzkiego, na chwilę obecną istnieje tylko w postaci kolorowych projektów, prospektów reklamowych, prezentacji multimedialnych i obliczeń finansowych składających się w harmonogramy i liczby.

Dążenie do spójności działań w obszarze infrastruktury drogowej i lotniczej, poprzez dopełnienie inwestycjami angażującymi środki finansowe w rozwój transportu kolejowego, stworzyłoby idealna, podręcznikową wręcz sytuację, jaka w logistyce uważana jest za klasyczną. Sprzężenie działań na tym polu i dążenie do takiego celu wymaga jednak zaangażowania wielu środowisk i zainteresowania postaci ze świata naukowego oraz grona osób sprawujących władzę na różnych szczeblach. Nie jest to łatwe zadanie. Niekiedy bywa niemożliwe do zrealizowania. W przypadku inwestycji cargo pod Łaskiem wszystko wskazuje, niestety, na ten pesymistyczny wariant.

Rozwój infrastruktury lotniczej w regionie łódzkim od lat, z punktu widzenia dostępności województwa, znajduje się na odległych pozycjach, poza główną stawką dziedzin z sektora transportowego. Sytuację taką mogłaby zdecydowanie poprawić, i zwiększyć udział transportu lotniczego $\mathrm{w}$ regionie łódzkim, inwestycja na miarę nowoczesnego portu lotniczego pod cywilna jurysdykcja, o ściśle określonych parametrach technicznych dostosowanych do aktualnych potrzeb użytkowników wewnętrznych i zewnętrznych. Z punktu widzenia powiazzań regionalnych daje to duże szanse na zwiększenie dostępności obszaru województwa łódzkiego i zintegrowanie go z innymi regionami zgodnie z zasadami strategii logistycznej. Cywilne lotnisko cargo pod Łaskiem doskonale wpisywałoby się w opracowaną strategię dla województwa łódzkiego, która zakłada utworzenie, rozwój i funkcjonowanie klastrów gospodarczych na terenie obszaru łódzkiego. Jedna z oczekiwanych jest funkcja logistyczno-magazynowa, będąca impulsem do aktywizacji gospodarczej w rejonie, w którym została zlokalizowana. Jako wartościowy i adekwatny przykład można tutaj podać sytuację, jaka wytworzyła się w miejscowości Stryków. Z chwilą realizacji pierwszoplanowych inwestycji drogowych (autostrada A1 i A2) nastapił lawinowy 
wzrost wartości gruntów pod inwestycje, co skutkowało bezpośrednio wzrostem poziomu życia mieszkańców, pojawieniem się nowych miejsc pracy, przyciągnięciem inwestorów, którzy środki finansowe zaczęli lokować w kolejne inwestycje. Taka sytuacja inicjuje swoistego rodzaju łańcuch, którego najważniejszym ogniwem jest decyzja o lokalizacji na danym terenie inwestycji infrastrukturalnej. W przypadku regionu łódzkiego transport lotniczy mógłby stać się gałęzią gospodarki, która ma szansę najszybciej się rozwijać. Transport lotniczy to koło zamachowe całego rozwoju gospodarczego. Jest stosunkowo bezpieczny, szybki, sprzyja wzrostowi mobilności społeczeństwa, wpływa na rozwój przedsiębiorczości. Przyczynia się też do obniżenia kosztów związanych z przewożeniem towarów i spedycja materiałów, szczególnie na duże odległości. Bywaja sytuacje, że jest jedynym - przy braku innych alternatyw - środkiem transportu, zapewniającym dotarcie nawet do niedostępnych rejonów świata, objętych konfliktami zbrojnymi lub o niekorzystnym ukształtowaniu i braku skomunikowania odległych terenów. Koncepcja Przestrzennego Zagospodarowania Kraju zakłada budowę lub rozbudowę istniejacych lotnisk regionalnych. W tę koncepcję wpisuje się również istnienie lotniska cargo pod Łaskiem. Wymaga to jednak korelacji dalekosiężnych strategicznych planów z zakresu planowania przestrzennego oraz rozwoju infrastruktury lotniczej. Odrębnym problemem jest tutaj chęć współpracy lub odwrotnie - brak zaangażowania i wykorzystania sprzyjających sytuacji przez lokalne władze. Tylko determinacja ludzi i ciągłe zaangażowanie władz w dane zagadnienie może przynieść oczekiwane owoce. Zbyt wąski horyzont działania, który przesłaniany jest dodatkowo przez codzienne problemy społeczne i coraz bardziej obciążające zadania budżetowe dla jednostek samorządu terytorialnego - sprawiaja, że takie gigantyczne przedsięwzięcia odsuwane sa w czasie i bezskutecznie czekaja na konkretne posunięcia.

Inwestycja infrastrukturalna w postaci lotniska cargo to przedsięwzięcie, którego realizacja sięga w przyszłość na co najmniej dekadę. Pomocna w jego rozpoczęciu i podjęciu decyzji pozwalającej na jego realizację będzie skutecznie przeprowadzona obecna inwestycja, jaką jest droga ekspresowa S8. Na tyle wydatnie skomunikuje ona obszar województwa łódzkiego, że samorzutnie pojawi się potrzeba dalszego rozwoju w obszarach transportu lotniczego. W każdej dziedzinie należy szukać możliwości dywersyfikacji, bo poszerzaja one spektrum działania. Być może w przyszłości okaże się, że właśnie ta inwestycja jest z punktu widzenia integralności i spójności systemów transportowych 
niezbędna i konieczna do zrealizowania. Przyniesie wtedy konkretne, namacalne korzyści ekonomiczne, polityczne, gospodarcze i społeczne.

Oba te zamierzenia infrastrukturalne tak naprawdę maja charakter koherentny i synergiczny. Należy zdać sobie z tego sprawę już teraz, aby w przyszłości uniknąć dodatkowych kosztów, niepotrzebnych dywagacji i nieprzemyślanych decyzji. Aby móc przewidzieć różnego rodzaju alternatywne rozwiązania pojawiające się w procesie budowy, trzeba już obecnie, na etapie przestrzennego planowania zauważyć wzajemnie dopełniające się funkcje tych dwóch przedsięwzięć infrastrukturalnych. Celem przy ich realizacji powinien być rozwój poprzez otwarcie się na nowe możliwości; rozwój, który wprowadza w małomiasteczkową prowincję kolory nowoczesnego świata; rozwój i postęp technologiczny idący w parze $z$ dobrymi stronami życia. To nowe spojrzenie zakłada poszanowanie przyrody, a człowiekowi żyje się lepiej.

\section{Podsumowanie}

W wyniku analiz przeprowadzonych w niniejszym rozdziale sformułowano następujące wnioski dotyczące zagadnień infrastruktury

\section{drogowej:}

- Wstapienie Polski do Unii Europejskiej diametralnie zmieniło sytuację geopolityczna naszego kraju, stwarzając Polsce szanse i możliwości poprawy dotychczasowych warunków egzystencji, zarówno dla obywateli, jak i podmiotów gospodarczych. Polska jako członek UE może pozyskiwać środki finansowe na nowe inwestycje infrastrukturalne, które przyczyniają się do integracji regionów, niwelują istotne różnice i bariery rozwoju ekonomicznego.

- Odpowiednia lokalizacja danego terytorium może wydatnie przyczynić się do zwiększenia poziomu rozwoju gospodarczego, polepszyć sytuację we wszystkich sektorach gospodarki, zniwelować różnice występujące $\mathrm{w}$ danym regionie, co również pozytywnie wpłynie na sytuację ekonomiczno-gospodarczą.

- Przez Polskę przebiega transeuropejski korytarz drogowy (TEN-T), dzięki czemu usprawnienie łączności między krajami europejskimi stało się możliwe i obecnie jest priorytetowym zadaniem, które zintegruje regiony oraz podniesie standardy bezpieczeństwa. Mając na uwadze pełniona funkcję w systemie dróg publicznych, opracowano klasyfikację z uwzględnieniem parametrów technicznych i warunków funkcjonalno-technicznych, dzieląc drogi publiczne na klasy 
oraz kategorie. Sieć połączeń infrastrukturalnych o odpowiednim standardzie technicznym jest czynnikiem stymulującym rozwój gospodarczy danego regionu.

- Sytuacja stanu infrastruktury drogowej, jej standardów oraz parametrów technicznych w województwie łódzkim jest wypadkowa stanu infrastruktury drogowej całego kraju. Jednakże wszelkiego rodzaju zapóźnienia z lat minionych maja szansę być zniwelowane w momencie budowy i oddania do użytkowania drogi ekspresowej S8, będącej priorytetową i strategiczna inwestycja nie tylko dla województwa łódzkiego.

- Istotnymi czynnikami charakteryzującymi stan dróg jest gęstość sieci drogowej, ich struktura (liczba dróg krajowych, powiatowych, gminnych), udział długości autostrad i dróg ekspresowych w ogólnej długości dróg publicznych na danym obszarze oraz liczba dróg o nawierzchni twardej na $100 \mathrm{~km}^{2}$ powierzchni. Wszystkie te dane precyzyjnie określone pozwalają na analizę stanu dróg danego województwa. Na podstawie wspomnianych danych można również określić potrzeby tego sektora gospodarki, oszacować koszty eksploatacji dróg będących pod zarządem gminnym i powiatowym.

- Przystępując do projektowania i realizacji strategicznego przedsięwzięcia infrastrukturalnego, jakim jest budowa drogi S8, należy przede wszystkim przeanalizować wszystkie dostępne badania dotyczące danego zamierzenia. Jednym z badań, które pozwoli oszacować skutki powstania nowego połączenia drogowego, jest obecny, powtarzany kilkakrotnie w różnych odstępach czasu, pomiar natężenia ruchu na istniejących drogach krajowych. Takie badania zostały przeprowadzone $w$ związku z uzasadnieniem przebiegu różnych wariantów przedmiotowej trasy. $Z$ zagadnieniem natężenia ruchu pojazdów wiąże się również pojęcie liczby pojazdów poruszających się po drogach publicznych. Na tym przykładzie można obserwować dynamikę wzrostu liczby aut na danym terenie.

- Budowa drogi ekspresowej S8 jest długo oczekiwana inwestycją infrastrukturalną naszego regionu. Zanim jednak zapadły ostateczne decyzje dotyczące lokalizacji tej drogi oraz zanim wydano pozwolenie na budowę, wszyscy mieszkańcy, a przede wszystkim władze lokalne stoczyły bój o jej obecną lokalizację. Historia wariantowania drogi, która tak bardzo zmobilizowała społeczności gminne i lokalnych samorządowców, zakończyła się pozytywnie. Analiza działań zachodzących nieprzerwanie od 2000 r. odzwierciedla determinację całego społeczeństwa, które brało czynny udział w słusznych zmaganiach 
ukierunkowanych na osiągnięcie celu. Z tą najważniejszą obecnie inwestycja związane są nadzieje na niepohamowany rozwój gospodarczy regionu łódzkiego.

- Integralnym zagadnieniem pojawiającym się przy realizacji tak dużych zamierzeń infrastrukturalnych jest aspekt ekologiczny. W takim przypadku najważniejszym dokumentem, o który występuje inwestor jest decyzja o środowiskowych uwarunkowaniach i decyzja o ustaleniu lokalizacji. Przedstawia ona ogólną charakterystykę danej inwestycji, określa zmiany oraz przyszłe powiązania drogowe, które pojawią się w stosunku do dotychczasowego układu drogowego. Dokumentacja ta z punktu widzenia procedur prawa dotyczącego nieruchomości jest istotna, bowiem reguluje podział gruntów, przez które przebiegać będą linie rozgraniczające nieruchomości. W decyzji środowiskowej zawarte są również wszystkie wytyczne dotyczące zagadnień flory i fauny na danym terenie. $Z$ troską i dbałością o zachowanie środowiska naturalnego przedmiotowa decyzja określa warunki, jakie muszą być spełnione, aby dane przedsięwzięcie spełniało uwarunkowania zrównoważonego rozwoju.

- Decyzja o środowiskowych uwarunkowaniach jest wyrazem dbałości również o interesy osób trzecich. W tym przypadku dotyczy to możliwych kolizji z istniejacymi urządzeniami technicznymi oraz sieciami uzbrojenia terenu. Pojęcie to zawiera również możliwe powiązania szczególnie do istniejących budynków użyteczności publicznej oraz do terenów zamkniętych.

- Ubieganie się przez inwestora o decyzję o środowiskowych uwarunkowaniach jest jednym z wielu elementów procesu inwestycyjnego, który dotyczy wszystkich zamierzeń infrastrukturalnych o strategicznym charakterze. Jest to przede wszystkim procedura złożona, skomplikowana i czasochłonna. Jeszcze do niedawna wymagała złożenia i uzyskania różnego rodzaju dokumentów oraz cząstkowych decyzji. Obecnie dla uproszczenia i przyspieszenia procesu infrastrukturalnego wydawana jest decyzja ZRID (decyzja o zezwoleniu na realizację inwestycji drogowej). Stanowi ona pokłosie nowelizacji specustawy drogowej, która miała miejsce w 2008 r., kiedy to przypadł boom inwestycyjny w naszym kraju.

- Przy podejmowaniu problematyki budowy dróg w Polsce newralgiczny staje się problem wywłaszczeń mieszkańców z terenów, przez które przebiegać będzie przyszła inwestycja drogowa. Wszyscy, jako użytkownicy dróg, chcielibyśmy jeździć nowoczesnymi, o wysokich standardach technicznych połączeniami drogowymi, jednak w momencie, 
gdy zapada decyzja budowy na naszym terenie, stajemy się zagorzałymi oponentami, wynajdując coraz to większy arsenał środków i możliwości w celu ukazania danego zamierzenia w negatywnym świetle. Właściciele gruntów robia wszystko, aby odwlec w czasie to, co i tak jest nieuniknione. Zagadnienie wywłaszczeń zawsze będzie budzić kontrowersje. To jak cięcie żywego organizmu. Jest bolesne i pozostawia trwałe rany.

- Jednym z wielu wymogów w trakcie procesu inwestycyjnego jest uzyskanie pozwolenia na budowę. Dlatego też każdy proces inwestycyjny prowadzony jest zgodnie z litera prawa budowlanego. Ta ustawa warunkuje i określa uczestników każdego procesu inwestycyjnego. Zalicza się do nich inwestora, inspektora nadzoru inwestorskiego, projektanta oraz kierownika budowy. Każda z tych osób musi posiadać samodzielne uprawnienia budowlane bez ograniczeń.

- Celem usprawnienia i efektywnego zorganizowania procesu budowy drogi S8, jej trasę podzielono na dziewięć odcinków o zróżnicowanej długości. Osobno na każdy odcinek prowadzone były procedury przetargowe, wyłaniano różnych wykonawców oraz podpisywano odrębne umowy. Ostatnie umowy z wykonawcami poszczególnych odcinków podpisano w styczniu 2012 r. Czas umowy określony jest na 27 miesięcy realizacji. Obecnie droga ekspresowa $\mathrm{S} 8$ jest w budowie.

- Integralne elementy drogi jako obiektu liniowego stanowią: pas drogowy, bezkolizyjne, w przypadku drogi ekspresowej S8, węzły drogowe oraz obiekty inżynierskie $w$ postaci miejsc obsługi pasażerów (MOP) i obwodów utrzymania drogi (OUS). Ponadto wzdłuż pasa drogowego, w miejscach określonych przez decyzję środowiskowa, instalowane są ekrany akustyczne, urządzenia oświetleniowe oraz różnego rodzaju przejścia dla zwierząt. Ważną rolę spełniają również urządzenia odwadniające, zbiorniki retencyjne, separatory substancji ropopochodnych. Wszystkie te obiekty i budowle wchodza w skład sieci uzbrojenia terenu i sa integralne $z$ dana droga.

- Analizując wszystkie aspekty budowy dróg w Polsce, trzeba wyeksponować bariery, jakie pojawiaja się w tej dziedzinie sektora publicznego. Bariery te maja charakter systemowy - walka z nimi może rozgrywać się na polu tworzenia i upraszczania prawa wykonawczego. Jako podstawową barierę rozwoju nowoczesnej infrastruktury można przedstawić problem skutecznego pozyskiwania i odpowiedniego alokowania środków finansowych na realizację strategicznych zamierzeń liniowych. Ich efektywne wydatkowanie to kolejna bolączka, z którą wiąże się jeszcze jedno zagadnienie w postaci partnerstwa 
publiczno-prywatnego. Jest to dobry sposób na zwiększenie skuteczności i efektywności, gdyż partner prywatny ma zupełnie inne podejście (przedsiębiorcze) do wykonywania zadań, niż ma to miejsce w przypadku sektora publicznego. Jednakże nawet najlepsze wykonawstwo i dobre zarządzanie publicznymi środkami polegnie w starciu z niespójnościa przepisów prawa dotyczących koncesjonowania i zamówień publicznych. Bariera proceduralna jest ponadto brak planów zagospodarowania dla danego obszaru lub plany cząstkowe, niestanowiące dla dużych strategicznych inwestycji najmniejszej wartości. Techniczną bariera rozwoju regionalnego jest ewidentne pogorszenie przepustowości sieci dróg. Wpływa to na niedostateczną dostępność danego terenu i podnosi koszty utrzymania dróg publicznych. Wobec dużej rozpiętości robót budowlanych na terenie różnych województw odczuwalny staje się brak dobrze wykształconej kadry o odpowiednich uprawnieniach branżowych. Temu zjawisku zaradzić moga lepsze warunki zdobywania wiedzy technicznej - większe stypendia i inne zachęty dla studentów kierunków politechnicznych.

- Głównym zagadnieniem poruszanym w rozdziale jest znaczenie infrastruktury drogowej i lotniczej w kontekście rozwoju regionu łódzkiego. W tym celu autorka poprzez analizę różnorodnych zagadnień z zakresu infrastruktury badała, w jakim stopniu nowe przedsięwzięcia (droga ekspresowa S8 i lotnisko cargo pod Łaskiem) będą determinowały: postęp technologiczny, przewagę konkurencyjna, poprawę warunków życia wszystkich mieszkańców oraz podniesienie poziomu innowacyjności. Wszystko to składa się na wszechstronny rozwój regionu.

W wyniku analiz przeprowadzonych w niniejszym rozdziale sformułowano następujące wnioski dotyczące zagadnień infrastruktury lotniczej:

- Obszar środkowej Polski charakteryzuje się umiarkowanymi warunkami pogodowymi i klimatem przejściowym. Takie warunki sprzyjały rozwojowi przemysłu, który na tym obszarze zaznaczył swą obecność ponad 200 lat temu. Z punktu widzenia rozwoju gospodarczego takie centralne położenie ma dla danego obszaru ogromne znaczenie. Dzięki temu na terenie województwa łódzkiego uprzemysłowienie (włókiennictwo i sukiennictwo) odcisnęło na długie lata swoje piętno, sprzyjając rozwojowi urbanistyki i rozkwitowi gospodarczemu regionu. Na terenie miasta Łodzi zaczęły powstawać fabryki włókiennicze, zakłady produkcji wełny i sukna, farbiarnie. Rozwijały się dziedziny 
pokrewne i wszystkie inne powiązane z przemysłem włókienniczym. Łódź jako stolica regionu ciągle się rozwijała, a mimo różnorakich perturbacji i zawirowań historycznych, nabrała charakteru nowoczesnej aglomeracji.

- Nowa reforma administracyjna z 1999 r. oznaczała zmiany w dotychczasowym układzie terytorialnym, co wpłynęło na kształt całego regionu łódzkiego (wprowadzenie instytucji powiatu oraz zmiana granic gmin). Struktury terytorialne, które funkcjonowały dziesiątki lat, uległy teraz przeformowaniu. Województwo łódzkie stało się jednym z 16 w Polsce. Wychodząc naprzeciw rosnącym potrzebom, opracowano Strategię Rozwoju Województwa Łódzkiego, w której nakreślono ramy odniesienia do obecnej sytuacji ekonomiczno-gospodarczej, kładąc duży nacisk na poprawę warunków życia, aktywizację obszarów strategicznych gospodarczo, integrację z innymi regionami, co wydatnie sprzyja rozwojowi ekonomicznemu. Ważnym punktem zwrotnym okazało się określenie nowego charakteru województwa, które zaczęło inwestować $\mathrm{w}$ nowe gałęzie przemysłowe określone przez dominujące klastry, takie jak produkcja prądu, sprzętu AGD oraz transport i spedycję.

- Logistyka transportu i spedycji to dziedzina przynosząca z roku na rok coraz większe dochody. Przeprowadzone badania jednoznacznie wskazuja na wzrost znaczenia tego sektora. Zwrócono uwagę na sprzyjająca lokalizację województwa łódzkiego dla przedsięwzięć infrastrukturalnych. Dzięki nim następuje dogodne skomunikowanie obszaru województwa, zwiększenie dostępności regionu, podniesienie jego atrakcyjności. Sprzyja to również pogłębieniu współpracy regionalnej. Biorąc pod uwagę czynniki, takie jak stopień zurbanizowania danego obszaru, stopień jego dostępności, stan sieci drogowej, nasilenie dobowe ruchu kołowego, trzeba mieć na uwadze również i inne alternatywne możliwości, jakie daje infrastruktura. Pożądana jest sytuacja, gdy dysponujemy wszystkimi możliwymi środkami infrastruktury drogowej, kolejowej i lotniczej. Taka kompilacja środków transportu jest najbardziej efektywna, sprzyja równomiernemu rozwojowi wszystkich gałęzi gospodarki regionu oraz ma dobry wpływ na rynek, generujac powstanie nowych miejsc pracy. Dodatkowym atutem w przypadku regionu łódzkiego jest dogodne, centralne położenie oraz pojawiająca się możliwość poprawy istniejącej infrastruktury transportowej. Jest to ściśle związane z budowa drogi S8. Zmiana na lepsze $w$ zakresie infrastruktury lotniczej jest możliwa w przypadku zrealizowania zamierzenia w postaci budowy 
lotniska cargo pod Łaskiem. Infrastruktura kolejowa (niedaleki węzeł Karsznice) byłaby doskonałym dopełnieniem tego obrazu. Stwarza to warunki, jakich nie ma w wielu innych regionach naszego kraju.

- Rozwinięty sektor transportu lotniczego w danym regionie może dać duży impuls dla rozwoju gospodarczego. Takim impulsem w przypadku regionu łódzkiego byłoby na pewno zrealizowanie zamierzenia infrastrukturalnego $\mathrm{w}$ postaci lotniska cargo $\mathrm{w}$ Łasku. Obecnie funkcjonujące lotnisko wojskowe $\mathrm{w}$ Łasku mogłoby współistnieć z lotniskiem cywilnym, stwarzając szerokie perspektywy rozwojowe nie tylko dla położonych tutaj gmin, ale zasięg oddziaływania wpływałby na cały regon łódzki. Duży wpływ na sytuację gospodarczą ma dogodne położenie gminy Łask pod kątem logistycznych powiązań infrastrukturalnych. Wykorzystując nadarzająca się szansę w postaci budowy drogi S8, można wydatnie skomunikować region łódzki z innymi regionami kraju, a nawet Europy.

- Ta ogromnych rozmiarów inwestycja na samym początku potrzebować będzie dużych nakładów finansowych, jednakże rozmach i różnorodność obiektów, jakie miałyby powstać w wyniku realizacji tej inwestycji pozwala przypuszczać, że będzie to zamierzenie bardzo dochodowe, obejmujące swym zasięgiem duży obszar zamieszkany przez tysiące ludzi. To znamionuje poprawę sytuacji na rynku pracy, wpływa na polepszenie uwarunkowań ekonomicznych, podniesienie poziomu życia.

- Dla potrzeb powstania cywilnego portu cargo opracowano „Koncepcje dostosowania lotniska wojskowego w Łasku do wymogów lotniska cywilnego", dzięki której wiadomo, jakie obiekty będa wchodziły w skład kompleksu cywilnego cargo oraz jak będzie wyglądać zaplecze techniczne $w$ najbliższym otoczeniu. Plany są ambitne, dalekosiężne i trudne do zrealizowania, jednakże można zaryzykować stwierdzenie, że przedmiotowa inwestycja transportu lotniczego przyniesie dla regionu więcej zysków niż strat.

- Koncepcja budowy lotniska cargo nie jest zamierzeniem nowym. Od 1999 r. duże zasługi na tym polu przyniosła działalność Spółki "Lotnisko Łask". Udziały w spółce ma obecnie dziewięć podmiotów (z sektora publicznego i prywatnego). Zachęta do realizacji tego przedsięwzięcia była perspektywa rozwoju związana z powstaniem lotniska cywilnego. Dodatkowa motywację stanowiła chęć partycypacji w kosztach i udziału w procesie budowy wielu silnych graczy gospodarczych, działających obecnie w Łódzkiej Specjalnej Strefie Ekonomicznej. Zamiar inwestowania $w$ ten kompleks logistyczny 
znamionuje jego możliwości rozwojowe, a tym samym może przynieść w przyszłości źródło dochodu dla wielu podmiotów gospodarczych, nowe miejsca pracy i satysfakcję z wykorzystania dogodnego momentu. Trzeba mieć wiedzę, wiele determinacji wewnętrznej oraz posiadać umiejętność koncepcyjnego spojrzenia w przyszłość, aby - na podstawie dowiedzionych naukowo faktów, obliczeń przyszłych dochodów i przede wszystkim zysku, stworzonych projektów i planów budowy - umieć dostrzec potencjał rozwojowy związany z tym przedsięwzięciem. Niestety, niewiele jest takich osób, a swoiste bariery, nie tylko prawne, ale wynikające również z innych niezrozumiałych przesłanek, już na samym starcie przekreślaja pojawiajacą się szansę dla regionu łódzkiego. 


\title{
13. Działalność Koła Naukowego „Uni-Logistics" w zakresie rozwoju infrastruktury logistyki
}

\author{
Łukasz Borowiecki*
}

Koło Naukowe Logistyki "Uni-Logistics" powstało na początku 2007 r., nie bez przyczyny na Wydziale Zarządzania Uniwersytetu Łódzkiego. Wydział posiadał wówczas najwyższą, pierwszą kategorię naukową (w pięciostopniowej skali), przyznana przez Ministerstwo Nauki i Szkolnictwa Wyższego. W roku akademickim 2007/2008 Wydział Zarządzania uruchomił studia licencjackie na kierunku logistyka. Zaś studia II stopnia (magisterskie) znalazły się w ofercie wydziału w roku akademickim 2010/2011. W chwili powstania Koła Naukowego „Uni-Logistics" żadna polska uczelnia państwowa nie posiadała w swojej ofercie kierunku logistyka. Spróbujemy wyjaśnić, dlaczego z bogatej oferty kół naukowych warto wybrać Koło Naukowe Logistyki "Uni-Logistics".

Nasze koło naukowe daje możliwość zarówno poszerzania wiedzy teoretycznej, jak i zdobywania praktycznych umiejętności w dziedzinie logistyki oraz nauk pokrewnych. Stwarza sposobność do podjęcia współpracy z innymi kołami, niekoniecznie jedynie na Uniwersytecie Łódzkim. Działalność w kole ułatwia nawiązanie kontaktów z przedsiębiorstwami logistycznymi, a co za tym idzie, np. odbycie praktyk nie tylko w ramach programu studiów, co zaowocowało m.in. podjęciem takich praktyk przez członków Koła "Uni-Logistics" w pierwszym roku jego funkcjonowania, we wrześniu 2007 r., w Ogólnopolskim Systemie Dystrybucji Wydawnictw „Azymut" Sp. z o.o. w Tulipan Parku w Strykowie koło Łodzi.

Wróćmy jednak do okoliczności utworzenia i początkowego funkcjonowania Koła „Uni-Logistics”. Pomysł założenia Koła Naukowego Logistyki zrodził się w grudniu 2006 r. Wówczas to dr inż. Remigiusz Kozłowski, nauczyciel akademicki w Katedrze Zarządzania Przedsiębiorstwem UŁ, wraz z mgr Izabelą Bednarską-Wnuk z Katedry Zarządzania UŁ przygotowali plan działania, którego celem było powstanie takiej organizacji.

* Mgr Łukasz Borowiecki - Katedra Logistyki, Wydział Zarządzania Uniwersytetu Łódzkiego, ul. Matejki 22/26, 90-237 Łódź. 
Nie posiadali jednak $w$ tamtym okresie doświadczenia $w$ prowadzeniu koła naukowego. Przeprowadzili zatem szereg konsultacji z opiekunami innych organizacji naukowych na Uniwersytecie Łódzkim i w Politechnice Łódzkiej. Skutkiem tych działań było nawiązanie współpracy z innymi kołami naukowymi, co zaowocowało w przyszłości wieloma konferencjami, seminariami i debatami. Następnie dr inż. Remigiusz Kozłowski, opiekun naukowy oraz mgr Izabela Bednarska-Wnuk, opiekun organizacyjny, przeprowadzili rozmowy z pracownikami dydaktycznymi i administracyjnymi Wydziału Zarządzania UŁ oraz władzami dziekańskimi w sprawie utworzenia koła, a także ewentualnych szans i zagrożeń z tym związanych.

3 stycznia 2007 r. na stronie internetowej wydziału, dzięki życzliwości jego władz i informatyków, zamieszczono informację o zamiarze utworzenia koła. Dla osób, które chciały zasilić szeregi koła naukowego, przygotowano kartę zgłoszenia oraz plakaty zachęcajace do wstapienia do tej organizacji. Na stronie internetowej wydziału można było przeczytać:

\section{Nowe Studenckie Koło Naukowe Logistyki}

W związku z dużym zainteresowaniem tematyką logistyki powstaje nowe Studenckie Koło Naukowe Logistyki.

Zapraszamy wszystkich chętnych studentów (dziennych, wieczorowych i zaocznych) na pierwsze spotkanie w środę 17.01.2007 r. w sali 363 o godz. 17.00.

Cele koła naukowego to:

- poszerzanie wiedzy teoretycznej oraz zdobywanie praktycznych umiejętności w dziedzinie logistyki,

- współpraca z innymi Studenckimi Kołami Naukowymi Logistyki,

- nawiązanie kontaktów z przedsiębiorstwami logistycznymi,

- organizowanie konferencji naukowych, warsztatów oraz seminariów.

Organizatorzy:

dr inż. Remigiusz Kozłowski

mgr Izabela Bednarska-Wnuk

Na pierwsze zebranie w dniu 17 stycznia 2007 r. przybyli: prodziekan Wydziału Zarządzania UŁ, prof. dr hab. M. Urbaniak, przyszli opiekunowie oraz 16 studentów z różnych roczników wydziału. Przedstawiono koncepcję funkcjonowania koła, a wszyscy obecni mieli możliwość swobodnego wypowiedzenia się i zaprezentowania swojej osoby jako kandydata do nowo utworzonego Studenckiego Koła Naukowego Logistyki.

Od 21 stycznia 2007 r. ruszyła tymczasowa strona koła pod adresem: www.fabos.home.pl/kolo.html, administrowana przez Tomasza Siemińskiego - jak dziś wiadomo - pierwszego lidera Sekcji Komunikacji, a także Bartłomieja Kraśniewskiego - jednego z pierwszych 
studentów, którzy zasilili szeregi koła. Trzy dni później, tj. 24 stycznia 2007 r., odbyło się zebranie, podczas którego ustalono strukturę wewnętrzną koła, a więc jego podział na Sekcję Naukowa, Organizacyjną i Komunikacji.

13 lutego 2007 r. miało miejsce spotkanie kół naukowych w sprawie zbliżających się za cztery dni Targów Edukacyjnych, zorganizowanych przez prof. dr. hab. M. Urbaniaka - wówczas prodziekana Wydziału Zarządzania UŁ ds. studenckich, kierownika Katedry Zarządzania Jakością UŁ. Nasze koło naukowe reprezentowali: dr inż. Remigiusz Kozłowski, mgr Izabela Bednarska-Wnuk, Filip Moterski - pierwszy przewodniczący koła i Rafael Jaworski.

Kolejne, trzecie już zebranie odbyło się 21 lutego 2007 r. Większą jego część poświęcono na projekt statutu, logo oraz - co także istotne - wymyślenie nazwy koła. Ostatecznie nadano nazwę: Studenckie Koło Naukowe Logistyki „Uni-Logistics". Pomysłodawca nazwy był Łukasz Borowiecki, dziś - opiekun organizacyjny koła.

Opiekunowie przygotowali niezbędną dokumentację do zarejestrowania koła w Rektoracie Uniwersytetu Łódzkiego. Nieoceniona przy tym pomocą wykazali się: doktorant Katedry Zarządzania Przedsiębiorstwem, mgr Maciej Żyliński i przewodniczący - Filip Moterski.

Pod koniec miesiąca, 27 lutego 2007 r., odbyło się zebranie kół naukowych w sprawie zbliżającego się Festiwalu Nauki, Techniki i Sztuki, które zostało zorganizowane przez prof. dr. hab. M. Urbaniaka. Koło Naukowe "Uni-Logistics" reprezentowali: dr inż. Remigiusz Kozłowski i mgr Izabela Bednarska-Wnuk. Dzień później odbyło się zebranie "wyborcze", na którym powołano zarząd koła. Przewodniczącym został Filip Moterski i kolejno:

- liderem Sekcji Organizacyjnej - Krzysztof Nowak,

- liderem Sekcji Naukowej - Rafael Jaworski,

- liderem Sekcji Komunikacji - Tomasz Siemiński.

Po zebraniu przygotowano szereg dokumentów, które podpisał kierownik Katedry Zarządzania Przedsiębiorstwem, prof. dr hab. Jan Jeżak. 1 marca 2007 r. Filip Moterski dostarczył do Rektoratu UŁ pełną dokumentację potrzebną do zarejestrowania koła. Sześć dni później dr inż. Remigiusz Kozłowski, opiekun naukowy, otrzymał zgodę podpisana przez prorektora UŁ ds. studenckich prof. dr hab. E. Małek.

W dniach 24-26 kwietnia 2007 r. odbyły się Targi Logistyczne organizowane przez Kolportera. Koło Naukowe Logistyki "Uni-Logistics” zaznaczyło tam swoją obecność. W czasie trwania targów odbyła się konferencja naukowa organizowana we współpracy z Instytutem Logistyki 
i Magazynowania w Poznaniu, seminarium i warsztaty dla firm transportowo-spedycyjnych przygotowane przez Związek Międzynarodowych Przewoźników Drogowych w Polsce, a także wizyty specjalistów zza wschodniej granicy (Ukraina, Białoruś, Rosja, Litwa, Łotwa, Estonia). W czasie targów miały miejsce również spotkania członków Polskiej Izby Spedycji i Logistyki, seminaria organizowane przez wydawnictwa branżowe oraz pokazy sprzętu organizowane przez wystawców.

Pierwsza, która odbiła się szerokim echem w środowisku naukowym, była konferencja dotycząca lokalizacji drogi S8. Została poprowadzona w największej auli Wydziału Zarządzania UŁ przy ul. Matejki 22/26, a jej przebieg relacjonowała stacja TVP 3. Na konferencji z szerokim udziałem zainteresowanych stron Koło Naukowe Logistyki "Uni-Logistics" podjęło próbę wyjaśnienia najważniejszych aspektów projektu budowy trasy S8. Wśród uczestników spotkać mogliśmy m.in.: - dziekana Wydziału Zarządzania UŁ prof. dr. hab. Bogdana Gregora,

- posła RP Piotra Krzywickiego,

- senatora RP Andrzeja Owczarka,

- Marszałka Województwa Łódzkiego Włodzimierza Fisiaka,

- Prezydenta Miasta Łodzi dr. Jerzego Kropiwnickiego oraz prezydentów miast sąsiednich,

- przedstawicieli samorządów lokalnych (władze miast, powiatów i gmin),

- kierownictwa przedsiębiorstw, na których przyszłość w znaczący sposób będzie wpływała lokalizacja trasy S8 (m.in. Schenker),

- przedstawicieli świata nauki (logistyków, prawników),

- media: telewizję (TVP 3, TOYA TV i inne), radio (RMF FM, Radio Łódź, VOX i inne) oraz prasę ("Gazetę Wyborcza”, "Dziennik Łódzki" i inne).

Niestety, mimo naszych usilnych starań i wcześniejszego potwierdzenia przybycia, z udziału w konferencji wycofał się zarząd Generalnej Dyrekcji Dróg Krajowych i Autostrad z Warszawy. Wśród przybyłych na konferencję osób nieobecność GDDKiA wzbudziła rozczarowanie, jak również podejrzenia, iż GDDKiA boi się merytorycznej dyskusji na uczelni wyższej.

W czasie trwania konferencji zebrani dyskutowali na temat aktualnej sytuacji związanej z budową trasy S8. Dyskusja wykazała absolutna bezzasadność merytoryczną argumentów używanych w ostatnim czasie przez GDDKiA. Warto pokreślić, iż zostały podjęte wszelkie działania integrujące środowisko zainteresowane problematyką wyboru trasy S8, czego przejawem był m.in. wspólny wyjazd do Warszawy 
27 czerwca 2007 r. w celu zaprotestowania przeciwko decyzji GDDKiA z dnia 1 czerwca 2007 r. o wyborze trasy w wariancie południowym.

Kolejną akcja, w której swoja obecność zaznaczyło Koło Naukowe "Uni-Logistics" była XI Edycja Łódzkich Targów Edukacyjnych. Targi odbyły się w dniach 6-8 marca 2008 r. na terenie Międzynarodowych Targów Łódzkich. Jest to impreza coroczna, która przyciąga tysiące ludzi, a więc wyśmienita okazja dla wystawców, których zadaniem jest m.in. przedstawienie uczniom szkół ponadgimnazjalnych i studentom własnej oferty edukacyjnej. Koło Naukowe "Uni-Logistics" miało swoje stoisko. Reprezentowali je: Krzysztof Nowak, Katarzyna Skalska, Mateusz Kacprzak oraz Damian Michalski. Członkowie koła starali się odpowiedzieć na wszystkie pytania dotyczące jego funkcjonowania, jak również kierunku logistyka. Głównym ich zadaniem było przedstawienie korzyści, jakie stwarza studiowanie na kierunku logistyka na Wydziale Zarządzania UŁ, jak również wskazanie, jakie umiejętności będzie posiadał absolwent tego kierunku. Zaprezentowana oferta edukacyjna cieszyła się sporym zainteresowaniem ze strony przybyłej młodzieży. Udało się zrealizować zamierzony cel, a więc przekonać młodzież szkół średnich do wyboru ścieżki edukacyjnej, jaką jest podjęcie studiów na Wydziale Zarządzania UŁ. Należy podkreślić, iż nawiązano współpracę z Zespołem Szkół Ponadgimnazjalnych nr 2 w Łodzi, co stwarzało nadzieję na przyszła owocną kooperację w aspekcie promowania wiedzy z zakresu nauk ekonomicznych ze specjalnością logistyka już na etapie szkół ponadgimnazjalnych.

20 marca 2008 r. członkowie Koła "Uni-Logistics” i studenci pierwszego roku logistyki wzięli udział w warsztatach z zakresu aktywnego poruszania się po rynku pracy. Akcja nosiła hasło: "Warsztaty umiejętności" i była zorganizowana w ramach projektu "Akcja Aktywacja” prowadzonego przez Studenckie Biuro Karier "Profil”. Warsztaty trwały 3 godziny i obejmowały ćwiczenia z zakresu negocjacji, komunikacji oraz efektywnych wystapień publicznych. Członkowie Koła "Uni-Logistics" mogli uzyskać informacje, jak napisać profesjonalne CV, list motywacyjny oraz jak przygotować się do rozmowy o pracę. Należy podkreślić, że spotkanie cieszyło się dużym zainteresowaniem i zostało przeprowadzone w niezwykle miłej i sympatycznej atmosferze. Wpłynęło to w pewnym stopniu na przełamanie bariery i dystansu między prowadzącymi a studentami.

16 kwietnia 2008 r. na Wydziale Ekonomiczno-Socjologicznym Uniwersytetu Łódzkiego miało miejsce spotkanie z Prezydentem Miasta Wrocławia dr. Rafałem Dutkiewiczem. Odbyło się ono w ramach 
projektu ogólnopolskiego, organizowanego przez Fundację Projekt: Polska oraz Stowarzyszenie Młode Centrum. Hasło tego projektu to nowoczesne zarządzanie $w$ administracji publicznej. Celem jest pokazanie na konkretnych przykładach i rozwiązaniach, że "administracja i sprawami samorządu czy państwa da się zarządzać profesjonalnie i efektywnie - tak, by działały z korzyścia dla obywateli". Jest to dobra droga do zainteresowania - zarówno młodych, jak i osób z doświadczeniem - uczestnictwem w poszukiwaniach nowych rozwiązań w logistyce oraz tworzeniem strategii i rozwiązań dla sfery publicznej.

Prezydent Wrocławia, jako czołowy reprezentant wspomnianego projektu w Polsce, poinformował o wprowadzonych w życie i planowanych strategiach rozwoju miasta Wrocławia. Odpowiadał na pytania uczestników, mówił też o przygotowaniach Wrocławia do rywalizacji o tytuł Europejskiej Stolicy Kultury i możliwości organizacji Targów Expo 2018. Poruszono również problem nieodpowiedniego połączenia Wrocławia z centralną Polską. Prezydent zwrócił uwagę, iż przy budowie trasy łaczącej Wrocław z Warszawa (droga S8) nie wolno pominąć Łodzi oraz zaznaczył, iż gdyby między Wrocławiem a Łodzią istniało dobre połączenie komunikacyjne, wpłynęło by to na organizowanie wielu projektów.

Na koniec opiekun naukowy Koła „Uni-Logistics” dr inż. Remigiusz Kozłowski wraz z przewodniczącym Krzysztofem Nowakiem wręczyli dr. Rafałowi Dutkiewiczowi dyplom, nadajac mu tytuł "Profesjonalnego Menedżera zarządzajacego rozwojem regionu".

W dniach 7-9 maja 2008 r. w Centrum Kongresowym Międzynarodowych Targów Poznańskich odbył się dziewiąty Polski Kongres Logistyczny, na którym pojawili się znani teoretycy i praktycy branży logistycznej z całej Europy. Dzięki uprzejmości i pomocy finansowej kilku profesorów Wydziału Zarządzania UŁ, członkowie Koła Naukowego "Uni-Logistics" mieli szanse uczestnictwa w tym wydarzeniu.

Hasło kongresu to "Nowe wyzwania - nowe rozwiązania". Poświęcony był wyzwaniom, jakie stawiaja logistyce nowe rynki, kwestie bezpieczeństwa, uwarunkowania polityczne, gospodarcze, nowoczesne technologie i metody organizacji. Istotną kwestią była dziesiąta rocznica działalności ECR Polska. W ciągu trzech dni odbyły się sesje plenarne i tematyczne. Każdy z uczestników spotkania po zarejestrowaniu się otrzymał identyfikator, szczegółowy program wykładów, teczkę z materiałami konferencyjnymi, broszurę reklamowo-informacyjna, a nawet nowe wydanie publikacji Logistyka w Polsce. Raport 2007, jak również zestaw słuchawkowy, który okazał się przydatny $\mathrm{w}$ trakcie prelekcji z udziałem gości z zagranicy. 
Członkowie Koła Naukowego "Uni-Logistics” po dniu obrad wybrali się zobaczyć nocne życie Poznania. Wówczas nawiązali kontakt z Kołem Naukowym "AELOGIC", które funkcjonuje przy Akademii Ekonomicznej w Poznaniu. Następnego dnia udało im się również zwiedzić Instytut Logistyki i Magazynowania.

Dzięki Polskiemu Kongresowi Logistycznemu zespół "Uni-Logistics" otrzymał niecodzienną okazję do poszerzenia horyzontów w tematyce logistyki, poznania specjalistów z tej dziedziny z całej Europy, jak również szansę na nawiązanie współpracy i poszerzenie swojej wiedzy.

29 maja 2008 r. zespół Koła „Uni-Logistics" wygrał turniej między kołami naukowymi działającymi na Wydziale Zarządzania U w kręgle w C.H. Manufaktura w Łodzi. Koordynatorem i pomysłodawca imprezy była Katarzyna Zielińska ze Studenckiego Koła Naukowego Marketingu "CreACTIVE" (Katedra Marketingu), z którym rywalizowały następujące koła naukowe: "Uni-Logistics” (wówczas działające przy Katedrze Zarządzania Przedsiębiorstwem), "Personalni” (Katedra Zarządzania Zasobami Ludzkimi), "Sigma” (Katedra Rachunkowości) oraz "Marketeam" (Katedra Marketingu). W składzie Koła Naukowego "Uni-Logistics" wystapili: Łukasz Borowiecki, Mariusz Poprawski i Michał Pokorski. Koło Naukowe "Personalni”, zajmujące się problematyką zarządzania zasobami ludzkimi, zajęło II miejsce, zaś Koło Naukowe Rachunkowości „Sigma” uplasowało się na III miejscu.

Warto wspomnieć, iż sprawozdanie z rozgrywki w kręgle w C.H. Manufaktura dzięki zgodzie dziekana Wydziału Zarządzania UŁ i uprzejmości informatyków widniało przez dłuższy czas na stronie internetowej Wydziału Zarządzania UŁ pod adresem: http://wz.uni.lodz.pl/news-resources/kregle2008.pdf.

4 czerwca 2008 r. w Filii Uniwersytetu Łódzkiego w Tomaszowie Mazowieckim w auli im. prof. dr. hab. Anzelma Iwanika odbyła się konferencja "Drogi ekspresowe S-74, S-12 i S-8 (Wrocław-tódź) i ich strategiczne znaczenie dla rozwoju Polski środkowo-wschodniej", zorganizowana przez Starostwo Powiatowe Tomaszów Mazowiecki, Urząd Miasta Tomaszowa Mazowieckiego oraz Koło Naukowe Logistyki "Uni-Logistics". Honorowy patronat nad konferencją objał minister infrastruktury Cezary Grabarczyk.

W komitecie organizacyjnym konferencji byli: członek Zarządu Powiatu Tomaszowskiego Jacek Kowalewski, wiceprezydent Tomaszowa Mazowieckiego Grzegorz Haraśny, opiekun naukowy Koła "Uni-Logistics" dr inż. Remigiusz Kozłowski, a także przewodniczący koła Krzysztof Nowak oraz p.o. lidera Sekcji Komunikacji „Uni-Logistics" Michał Droś. 
Członkami "Uni-Logistics", biorącymi udział w przygotowaniu i realizacji konferencji, byli: Krzysztof Nowak, Michał Droś, Mariusz Poprawski, Michał Gnoiński, Paweł Pipczyński, Łukasz Borowiecki, Bernard Piechota, Michał Głowacki, Mariusz Wychowaniec, Piotr Nowak i Łukasz Kwapisiewicz.

Celem konferencji była analiza problematyki trasowania dróg ekspresowych S74 i S12 oraz ich strategiczne znaczenie dla rozwoju powiatu tomaszowskiego i opoczyńskiego, regionu świętokrzyskiego i całej Polski środkowo-wschodniej. Konferencję prowadził członek Zarządu Powiatu Tomaszowskiego Jacek Kowalewski. Przybyło $\mathrm{n}$ wielu znakomitych gości, w tym m.in.:

- przedstawiciele parlamentu: poseł RP Dariusz Seliga i poseł RP Robert Telus,

- przedstawiciele władz wojewódzkich i samorządowych woj. łódzkiego: Marszałek Województwa Łódzkiego Włodzimierz Fisiak, Wiceprezydent Miasta Łodzi Włodzimierz Tomaszewski, Prezydent Miasta Sieradza Jacek Walczak, Prezydent Tomaszowa Mazowieckiego Rafał Zagozdon oraz władze powiatów i gmin woj. łódzkiego i świętokrzyskiego,

- przedstawiciele instytucji pozarządowych: dyrektor Biura Planowania Przestrzennego Województwa Łódzkiego Ewa Paturalska, przedstawiciel Zarządu GDDKiA Oddział w Łodzi Marek Brodowski, pełnomocnik wojewody łódzkiego ds. systemów komunikacyjnych Andrzej Cymerman,

- przedstawiciele Wojska Polskiego: ppłk Piotr Stelaszczyk i kpt. Zbigniew Król,

- przedstawiciele środowisk naukowych: kierownik Katedry Zarządzania Miastem i Regionem Wydziału Zarządzania UŁ, przewodniczący Komitetu Przestrzennego Zagospodarowania Kraju prof. dr hab. Tadeusz Markowski; adiunkt Katedry Zarządzania Przedsiębiorstwem Wydziału Zarządzania UŁ, opiekun naukowy Koła "Uni-Logistics" dr inż. Remigiusz Kozłowski; z Instytutu Geografii Miast i Turyzmu Wydziału Nauk Geograficznych UŁ dr Anita Wolaniuk; z Katedry Ubezpieczeń Wydziału Ekonomiczno-Socjologicznego UŁ, wiceprezes Biura Brokerów Ubezpieczeniowych „Maxima Fides" dr Katarzyna Pastusiak.

Uczestnicy konferencji zapoznali się z merytorycznymi argumentami, które przemawiały za aktualizacja przebiegu trasy S74 w wariancie "tomaszowskim". Minister infrastruktury Cezary Grabarczyk zobowiązał się do zapewnienia przebiegu trasy S74 właśnie w tym wariancie. Przedstawiciele Koła "Uni-Logistics” - opiekun naukowy dr inż. Remigiusz 
Kozłowski wraz z przewodniczącym Krzysztofem Nowakiem uhonorowali ministra infrastruktury dyplomem.

Należy zauważyć, iż termin konferencji nie był przypadkowy. Jej uczestnicy udali się autokarami na skwer "4 Czerwca 1989 roku", gdzie w 19. rocznicę pierwszych wolnych wyborów w III Rzeczpospolitej złożyli kwiaty. Koło Naukowe Logistyki „Uni-Logistics”, które brało udział w całości przygotowania i realizacji konferencji, miało okazję zrobić sobie pamiątkowe zdjęcie z ministrem infrastruktury Cezarym Grabarczykiem.

3 października 2008 r. na Wydziale Zarządzania Uniwersytetu Łódzkiego odbyła się debata społeczna pt. „Jaki transport w zrównoważonym rozwoju” z cyklu: „Innowacyjne myślenie kluczem do zrównoważonego rozwoju". Partnerem był Wydział Zarządzania UŁ, zaś organizatorem Koło Naukowe Logistyki "Uni-Logistics". Debata realizowana była przez Instytut na rzecz Ekorozwoju w ramach programu aktywnej edukacji Eko-Herkules.

W debacie wzięło udział ponad 60 osób, m.in. członkowie pozarzadowych organizacji ekologicznych i społecznych, przedstawiciele administracji publicznej, organizacji konsumenckich, firm logistycznych, jak również - co istotne - środowisk naukowych i akademickich. Każdy z uczestników miał okazję do swobodnej wymiany poglądów i wyrażenia swojej opinii.

Kilkanaście dni później, w dniach 17-19 października 2008 r. miał miejsce wyjazd integracyjny całego zespołu "Uni-Logistics" do Sulejowa. Przebywaliśmy na terenie Ośrodka Doskonalenia Kadr Służby Więziennej. Jak się okazało, oprócz dobrej organizacji i współdziałania w przygotowaniu różnych akcji, konferencji, debat - nasze koło naukowe potrafiło się dobrze bawić. Celem wyjazdu było zacieśnienie współpracy studentów Wydziału Zarządzania ze studentami Wydziału Prawa i Administracji UŁ ze Studenckiego Koła Penitencjarnego. W trakcie wyjazdu odwiedziliśmy (dzięki pomocy członka Zarządu Powiatu Tomaszowskiego Jacka Kowalewskiego) przepływową Elektrownię Wodną w Smardzewicach, uczestniczyliśmy w olimpiadzie sportowej, wieczorach tanecznych, wspólnej zabawie i śpiewie karaoke, a następnego dnia - bitwie paintballowej.

Po upływie około miesiąca zespół "Uni-Logistics" miał okazję promować swoje koło naukowe podczas Festiwalu Kół Naukowych Uniwersytetu Łódzkiego, który miał miejsce 20 listopada 2008 r. w gmachu Biblioteki Uniwersytetu Łódzkiego. Była to wyśmienita okazja dla wszystkich kół naukowych do wspólnej integracji, wymiany 
poglądów i doświadczeń, jak również zaprezentowania swoich zasług. Nawiązano kontakty z innymi organizacjami studenckimi. Następnie odbyło się spotkanie w Sali Posiedzeń Senatu Uniwersytetu Łódzkiego z prorektorem $U Ł$ ds. studenckich i toku studiów prof. dr. hab. Pawłem Maślanką oraz z Radą Kół Naukowych UŁ na temat funkcjonowania i finansowania kół naukowych.

W dniach 11-14 lutego 2009 r. na terenie łódzkiej hali Expo odbyły się coroczne Targi Edukacyjne, na których nie zabrakło oczywiście zespołu "Uni-Logistics", reprezentującego Wydział Zarządzania UŁ. Członkowie koła opiekowali się swoim stoiskiem, zachęcając wszystkich zainteresowanych do studiowania na Wydziale Zarządzania. Oferta edukacyjna Uniwersytetu Łódzkiego cieszyła się dużym zainteresowaniem. To samo można powiedzieć o Kole Naukowym Logistyki "Uni-Logistics”.

Od 26 do 27 lutego 2009 r. zespół "Uni-Logistics" wziął udział w ósmej konferencji logistycznej zorganizowanej przez Studenckie Koło Naukowe AELOGIC, działające przy Uniwersytecie Ekonomicznym w Poznaniu. Na konferencji poruszono problem lotnictwa i astronautyki. W pierwszym dniu w sposób uroczysty powitano wszystkich przybyłych gości, uczestników i prelegentów. Wykłady poświęcono logistycznym wyzwaniom XXI wieku. Swoje referaty wygłosili: przedstawiciele Centrum Badań Kosmicznych Polskiej Akademii Nauk oraz szef Oddziału Szkolenia Lotniczego Dowództwa Sił Powietrznych. Po prezentacji referatów nastapiła wzajemna integracja i poznanie się członków kół naukowych oraz zaproszenie wszystkich do Metropolitan Club na wspólną zabawę. Drugi dzień przebiegał pod hasłem "Dnia Partnera”, odbyło się również szkolenie pod nazwą "Student w meandrach rynku pracy". Na koniec konferencji wszystkim zgromadzonym zrobiono pamiątkowe zdjęcie.

7 marca 2009 r. w gmachu Wydziału Zarządzania UŁ odbyły się, jak co roku, Dni Otwarte wydziału. Zadaniem Koła "Uni-Logistics" było zachęcenie jak największej liczby osób do studiowania na kierunku logistyka. Warto podkreślić, że przybyło ok. 100 zainteresowanych osób. W następnej kolejności prodziekan ds. studenckich prof. dr hab. Ewa Śnieżek opowiadała o wydziale. Stoiska odwiedzali maturzyści i ich rodzice, którzy dopytywali się o różne kierunki studiów.

W dniach 26-27 marca 2009 r. miało miejsce IV Seminarium branży TSL "Dni Transportu 2009". Konferencja odbyła się na Politechnice Krakowskiej. Swój udział potwierdziło 14 kół naukowych z całej Polski, w tym nasze Koło "Uni-Logistics".

W kolejnych dniach 2009 r. miało miejsce "Logistics Party - Połowinki 2009" dla studentów IV semestru logistyki studiów licencjackich 
dziennych, wieczorowych, zaocznych oraz III semestru uzupełniających studiów magisterskich kierunku zarządzanie, specjalność logistyka. Impreza, która odbyła się w klubie "Synapsa”, dawała możliwość wspólnej zabawy w gronie osób, których głównym zainteresowaniem jest właśnie logistyka.

3 marca 2009 r. „Uni-Logistics" pozyskało sponsora - firmę produkująca chemię budowlaną Torggler Polska Sp. z o.o. Zebrało się ok. 180 osób, w tym goście: dr inż. Remigiusz Kozłowski, przedstawiciele firmy Torggler Polska Sp. z o.o. Krzysztof Plewiński, Marek Górniak oraz reprezentanci Studenckiego Koła Naukowego Rachunkowości „Sigma". W trakcie spotkania odbył się szereg konkursów:

- merytoryczny - „Milionerzy”, przygotowany przez dr. inż. R. Kozłowskiego,

- Mistrz Kufla,

- Mistrz/Mistrzyni Słomki.

W kolejnych dniach odbyła się wycieczka KNL „Uni-Logistics” do łódzkiej fabryki Della. Jej celem było poszerzenie wiedzy naukowej o wszelkich procesach zachodzących m.in. w łańcuchu dostaw fabrykomontowni łódzkiego Della. Pomysłodawca i organizatorem wycieczki była Agnieszka Tomas. Zwiedziliśmy fabrykę Della, pozyskaliśmy informacje o "mózgu" firmy Dell - Data Center, które umożliwia pracę całego zakładu w Łodzi i nie tylko. W następnej kolejności zaproszono nas do sali w której prezentowana była cała gama produktów montowanych przez Della. Potem przeszliśmy do sali konferencyjnej, gdzie wysłuchaliśmy prezentacji "Corporate/EMFP Overview”. Na koniec przewidziano czas na zadawanie pytań przedstawicielom firmy.

23 kwietnia 2009 r. Koło Naukowe "Uni-Logistics" odwiedziło fabrykę pralek koncernu Bosch und Siemens Hausgeräte, znajdująca się w Łodzi przy ul. Papierniczej 7. Celem wycieczki było zapoznanie się z organizacją i przebiegiem procesu produkcji pralek. Warto zaznaczyć, iż Piotr Staniszewski - lider Sekcji Naukowej „Uni-Logistics” - odbywał w tym czasie praktyki we wspomnianej fabryce. Uczestnicy mieli okazję poznać nie tylko sam proces produkcyjny, lecz także zobaczyć przykłady zastosowania rozwiązań z obszaru automatyki przemysłowej. Można było dowiedzieć się ciekawostek dotyczących logistyki produkcji, zarządzania jakościa, ale też o zwyczajnym działaniu samej pralki.

W dniach 23-24 kwietnia 2009 r. na terenie Akademii Morskiej w Gdyni odbyła się I Ogólnopolska Konferencja Studencka: Student Maritime Conference, organizowana przez Koło Naukowe "Translog". Temat brzmiał: „Konteneryzacja - stan obecny i perspektywy rozwoju”. 
Zespół „Uni-Logistics" reprezentował Wydział Zarządzania UŁ i brał czynny udział w wykładach.

$\mathrm{Na}$ konferencji stawiły się reprezentacje uczelni z całego kraju, m.in. Wyższej Szkoły Logistyki z Poznania, Politechniki Śląskiej, Akademii Morskiej ze Szczecina i Uniwersytetu Gdańskiego.

W dniach 8-9 maja 2009 r. na terenie Wydziału Organizacji i Zarządzania Politechniki Łódzkiej miała miejsce II Konferencja Naukowa z cyklu Forum Młodych Menedżerów: „Współczesne metody zarządzania w teorii i praktyce gospodarczej", zorganizowana przez Koło Naukowe "Ludzie - Biznes - Technologie". Nie zabrakło reprezentacji Wydziału Zarządzania UŁ w składzie Koła "Uni-Logistics".

Wśród gości można było spotkać przedstawicieli Politechniki Wrocławskiej, Politechniki Warszawskiej, Uniwersytetu Jagiellońskiego, Szkoły Głównej Gospodarstwa Wiejskiego i Uniwersytetu Ekonomicznego w Poznaniu. W pierwszym dniu konferencji poruszono problem przedsiębiorczości oraz koncepcji i narzędzi zarządzania we współczesnym przedsiębiorstwie. Wszystkich przybyłych gości powitał dziekan Wydziału Organizacji i Zarządzania Politechniki Łódzkiej prof. dr hab. Ryszard Grądzki. Wykład inauguracyjny poprowadził prof. dr hab. Józef Penc. Następnie prof. dr hab. Stefan Lachiewicz zaprezentował swój artykuł. W następnej kolejności wykład o prawie antymonopolowym wygłosił Maciej Fornalczyk z firmy COMPER Fornalczyk.

Pierwszego dnia pod wieczór odbyło się spotkanie integracyjne w kręgielni "Grakula" w C.H. Manufaktura. Na imprezie pojawił się dziekan Wydziału Organizacji i Zarządzania Politechniki Łódzkiej prof. dr hab. R. Grądzki. Drugi dzień konferencji odbył się pod hasłem przedstawienia uczestnikom filmu promocyjnego o Łodzi. Wygłoszone zostały referaty na temat franchisingu i zarządzania projektami.

30 kwietnia 2009 r. reprezentacja „Uni-Logistics” miała okazję poznać, jak funkcjonuje łódzki magazyn firmy Flextronics. Celem wycieczki było poszerzenie wiedzy na temat procesów zachodzących w nowoczesnym magazynie. Firma Flextronics jest operatorem logistycznym Della. Warto zaznaczyć, iż łódzki oddział Flextronics współpracuje z klientami na bazie rozwiązania typu Vendor Inventory Management. W następnej kolejności uczestnicy wycieczki zapoznali się z zasadami BHP oraz wszelkimi innymi przepisami obowiązującymi na terenie zakładu. Zwiedzili strefę przyjęć, strefę tzw. Value add, czyli wartości dodanej. Należy podkreślić, iż firma specjalizuje się w dodatkowych funkcjach, takich jak sprawdzanie poprawności działania sprzętu oraz naprawy. 
W dniach 22-23 października 2009 r. na Wydziale Zarządzania Ut odbyła się konferencja pt. „Klaster logistyczny na tle procesów rozwoju regionu". Organizatorem był Zakład Logistyki, Katedra Zarządzania Miastem i Regionem UŁ, jak również Koło Naukowe Logistyki "Uni-Logistics". Honorowy patronat nad konferencja objął Prezydent Miasta Łodzi dr Jerzy Kropiwnicki. Spotkanie dotyczyło problematyki trendów w funkcjonowaniu klastrów logistycznych.

Pierwsza sesja konferencji nosiła tytuł: „Klaster jako element przestrzennego zagospodarowania". Poprowadził ja prodziekan Wydziału Gospodarki Międzynarodowej Uniwersytetu Ekonomicznego w Poznaniu prof. dr hab. Maciej Szymczak. Kolejna sesja odbyła się na temat: „Innowacje w procesach logistycznych", zaś trzecia, która poprowadził dr inż. Remigiusz Kozłowski: „Rozwiązania logistyczne w praktyce gospodarczej”.

Drugi dzień konferencji rozpoczałł się sesją pt. „Infrastruktura logistyczna". Następnie członek Zarządu Powiatu Tomaszowskiego Jacek Kowalewski, który brał czynny udział w konferencji nt. dróg 4 czerwca 2008 r. w Tomaszowie Mazowieckim, zaprezentował obecną i przyszła sytuację klastrów: produkcyjnego i logistycznego w powiecie tomaszowskim oraz planowany tam układ dróg. Druga sesja nosiła tytuł: "Powiązania w łańcuchu logistycznym". Została poprowadzona przez prof. dr. hab. J. Sosnowskiego, który następnie podsumował konferencję wraz $z$ dr. inż. Remigiuszem Kozłowskim, opiekunem naukowym „Uni-Logistics".

Od 23 października 2009 r. trwał pierwszy etap Akademickiej Ligi Logistyków Wincanton. Trwał niemalże do północy 25/26 października 2009 r. Zespół „Uni-Logistics” w składzie 10 członków zaprojektował magazyn na podstawie danych zawartych w "Case study". Otrzymał 14 pkt na 20 i zajmował po I etapie 3. miejsce, ze strata 2 pkt do pierwszego zespołu. Drugi etap odbywał się w dniach 7-9 listopada 2009 r. Zespół „Uni-Logistics" musiał zmierzyć się z problematyką logistyki humanitarnej. Po II etapie zespół, z sumą 24 punktów, zajmował 12. miejsce, ze stratą 15 pkt do lidera. Trzeci etap wystartował o godz. 18:00 dnia 20 listopada 2009 r. i zakończył się w niedzielę 22 listopada minutę przed północa. Wówczas KNL "Uni-Logistics" zgromadziło 52 pkt, co pozwoliło zajać 11 . miejsce, ze stratą 10 pkt do lidera.

W dniach 10-11 grudnia 2009 r. na Politechnice Wrocławskiej odbyło się V Ogólnopolskie Forum Studentów Transportu i Logistyki TransLogistics 2009. W pierwszym dniu konferencji były prezentowane referaty dotyczące gałęzi logistyki - transportu: drogowego, morskiego, ekologicznego miejskiego itp. W tym dniu wieczorem zespół "Uni-Logistics" udał się do klubu na imprezę integracyjną. Drugi dzień dotyczył 
logistyki. Poruszono problematykę systemów RFID. Po wygłoszeniu referatów ekipa "Uni-Logistics" wyruszyła w drogę powrotna do domu.

13 lutego 2010 r. na Wydziale Zarzadzania UŁ odbyło się szkolenie „Palety EUR w praktyce” i warsztaty „Praktyczne aspekty gospodarki magazynowej", zorganizowane przez Koło "Uni-Logistics" wspólnie z przedstawicielami firmy InterConsulting, m.in. Pawłem Wojciechowskim. Poruszono problematykę z zakresu gospodarki magazynowej. Uroczystość otworzyła dziekan Wydziału Zarządzania UŁ prof. dr hab. Ewa Walińska, witając wszystkich zgromadzonych i zapraszając do studiowania na Wydziale Zarządzania w ramach drugiego stopnia studiów związanych z logistyką, uruchamianego w roku akademickim 2010/2011.

17 kwietnia 2010 r. członkowie "Uni-Logistics" w 8-osobowym składzie wybrali się do fabryki firmy Coca-Cola HBC Polska, mieszczącej się w Łodzi przy ul. Traktorowej 139/141. Poznali historię firmy, której łódzka siedziba stanowi jeden z czterech zakładów produkcyjnych tej spółki w Polsce.

W dniach 12-14 maja 2010 r. odbył się Polski Kongres Logistyczny Logistics \& Eurolog 2010. Koło Naukowe Logistyki reprezentowane było przez 9-osobowy zespół. W większości program realizowany był na terenie Centrum Kongresowego Międzynarodowych Targów Poznańskich.

Podczas inauguracji roku akademickiego 2010/2011 na Wydziale Zarządzania UŁ Koło Naukowe "Uni-Logistics" sprawowało opiekę nad firmą Dachser.

W okresie październik-listopad 2010 r. "Uni-Logistics” zajęło się projektem „Błękitno-Zielona Sieć" dla Międzynarodowego Instytutu PAN - Europejskiego Reginalnego Centrum Ekohydrologii pod auspicjami UNESCO. Jego efektem była publikacja: K. Krauze, Ł. Żelewski, R. Włodarczyk, Rola zieleni miejskiej w mieście przyszłości - Błękitno-Zielona Sieć Łodzi, "Acta Universitatis Lodziensis. Folia biologica et oecologica: Supplementum" 2010.

W grudniu 2010 r., jak co roku, zespół "Uni-Logistics" opracowywał i rozsyłał e-kartki z życzeniami świątecznymi dla władz wydziału, organizacji studenckich itp.

3 marca 2011 r. braliśmy udział w warsztatach „Zarządzanie Łańcuchem Dostaw (symulacja)" z cyklu „Biznes w Praktyce”, organizowanych w Warszawie przez firmę Danone.

7 kwietnia 2011 r. odbyliśmy wycieczkę do magazynu centralnego firmy Komfort S.A. w Tulipan Park w Strykowie. Jest to największy 
i najnowocześniejszy magazyn dystrybucyjny wykładzin w Europie Środkowej.

12 kwietnia 2011 r. Koło Naukowe "Uni-Logistics" brało udział w spotkaniu z dr. Bartłomiejem Kurzykiem dotyczącym finansowania kół naukowych na Wydziale Zarządzania UŁ oraz działania platformy do komunikacji pomiędzy kołami naukowymi na wydziale.

14 kwietnia 2011 r. odbyło się spotkanie "Drzwi Otwarte Łodzi Akademickiej" na Wydziale Zarządzania UŁ. Uczestniczyło w nim ok. 100 licealistów ze szkół regionu łódzkiego. Koordynowała je Sekcja ds. promocji i kontaktów z biznesem Wydziału Zarządzania UŁ. W tym samym dniu Koło "Uni-Logistics" reprezentowało wydział oraz wspierało działania Uniwersytetu Łódzkiego w ramach projektu „Uniwersytet Zawsze Otwarty". Była to oferta edukacyjna skierowana do uczniów szkół średnich w celu zachęcenia ich do studiowania na naszym wydziale.

Również, jak co roku, na Wielkanoc 2011 rozesłaliśmy e-kartki z życzeniami świątecznymi.

22 września 2011 r. odbyło się spotkanie z koordynatorem studenckich kół naukowych na Wydziale Zarządzania UŁ dr. Bartłomiejem Kurzykiem. Podczas projektu „Festiwal Kół Naukowych - sKOŁOwanie” na Wydziale Zarządzania "Uni-Logistics" miało okazję zaprezentować swoje możliwości i osiągnięcia.

8 listopada 2011 r. miała miejsce konferencja „Rzetelny Przewoźnik". Spotkanie poprowadzono w Akademii Humanistyczno-Ekonomicznej w Łodzi przy ul. Rewolucji 1905 nr 52. Poruszono problematykę kradzieży w branży TSL. Natomiast 22 listopada 2011 r. podczas dni otwartych odwiedziliśmy Miejską Pracownię Urbanistyczną.

26 listopada 2011 r. na Wydziale Zarządzania odbyła się uroczysta Gala Absolwenta. Sponsorem była firma Dachser - członek Rady Biznesu. Spośród członków "Uni-Logistics" Łukasz Borowiecki odebrał dylom, a Michał Głowacki wraz z dyplomem otrzymał List gratulacyjny Rektora. Przybyło wielu gości, m.in. wojewoda łódzki, przedstawiciele firmy Dachser, europoseł Joanna Skrzydlewska.

29 listopada 2011 r. przez Instytut Spraw Obywatelskich (INSPRO) zostało zorganizowane seminarium w Centrum Konferencyjnym Zielna przy ul. Zielnej $37 \mathrm{w}$ Warszawie. Było to trzecie spotkanie $\mathrm{w}$ ramach ogólnopolskiej kampanii społecznej "Tiry na tory".

6 grudnia 2011 r. w Instytucie Europejskim przy ul. Piotrkowskiej 262/264 i 13 grudnia 2011 r. na Politechnice Łódzkiej przy ul. Wólczańskiej 215 odbyły się konsultacje społeczne dotyczące budowy kolejowych tuneli średnicowych w kodzi. Nie zabrakło delegacji 
"Uni-Logistics" na obu spotkaniach. Idea konsultacji było przedstawienie łodzianom najlepszych opcji dotyczących budowy tuneli kolejowych pod powierzchnia miasta.

6 marca 2012 r. członkowie koła wzięli udział w prezentacji kół naukowych i organizacji studenckich na Wydziale Zarządzania UŁ. Celem było przedstawienie oferty edukacyjnej wydziału oraz zachęcenie studentów do wstapienia do organizacji, jaka jest koło naukowe. Organizatorzy byli solidnie przygotowani do udzielenia wszelkich informacji zainteresowanym.

W dniach 12-13 kwietnia 2012 r. członkowie "Uni-Logistics" uczestniczyli w konferencji "Logistyka a bezpieczeństwo", która odbyła się w Akademii Obrony Narodowej w Warszawie. Wygłosili swoje referaty. Celem spotkania było uświadomienie uczestnikom, jak ważne jest bezpieczeństwo osób pracujących na co dzień w transporcie i biorących czynny udział w procesach logistycznych.

16 kwietnia 2012 r. zespół „Uni-Logistics” wraz z opiekunem naukowym, prof. dr. hab. inż. Remigiuszem Kozłowskim, wział udział w spotkaniu "Perspektywy komunikacyjne kodzi - szanse i zagrożenia" w ramach zorganizowanego w dniach 16-23 kwietnia 2012 r. Festiwalu Nauki, Techniki i Sztuki. Spotkanie odbyło się w Łódzkim Towarzystwie Naukowym. Wzięli w nim udział profesorowie Uniwersytetu Łódzkiego i Politechniki Łódzkiej, władze samorządowe oraz przedstawiciele Sejmu RP - wicemarszałek Sejmu Cezary Grabarczyk i wiceprezydent Miasta Łodzi Radosław Stępień. Poruszono problematykę związaną z infrastruktura drogowa w obszarze miasta, obwodnic Łodzi, omówiono też problemy lokalizacji lotniska na obszarze województwa, przebudowy dworca Łódź Fabryczna i budowy tuneli średnicowych pod Łodzia.

17 kwietnia 2012 r. Koło Naukowe "Uni-Logistics" przeprowadziło prezentację pt. „Przyszłościowe rozwiązania w transporcie i możliwości ich implementacji w regionie łódzkim" w ramach trwającego Festiwalu Nauki, Techniki i Sztuki. 19 kwietnia 2012 r. miało miejsce wystapienie pt. "Nowoczesne rozwiązania w transporcie lotniczym i możliwości ich wdrożenia w regionie łódzkim". Spotkania z 17 i 19 kwietnia 2012 r. cieszyły się dużym zainteresowaniem odwiedzającej wydział młodzieży szkół średnich.

14 maja 2012 r. odbyły się na Wydziale Zarządzania UŁ zajęcia w ramach „Uniwersytetu Zawsze Otwartego". W spotkaniu uczestniczyli licealiści i ich opiekunowie. Pozwoliło ono na zapoznanie uczniów szkół ponadgimnazjalnych z ofertą edukacyjną wydziału i pokazało, jak można kształcić się i rozwijać poprzez udział w kołach naukowych. 
15 maja 2012 r. chętni członkowie Koła Naukowego "Uni-Logistics" napisali test wstępny na płatne praktyki menedżerskie w firmie Procter \& Gamble jako jeden z elementów rekrutacji na praktyki w okresie od lipca do września 2012 r. w firmie w Aleksandrowie Łódzkim. Spotkanie odbyło się po wcześniejszych ustaleniach z Moniką Kowalską - specjalista ds. rekrutacji w firmie Procter \& Gamble.

1 czerwca 2012 r. odbył się Piknik Kół Naukowych. Jego celem było połączenie interaktywnych form nauki i zabawy, prezentowanych podczas Pikniku Wiedzy i Nauki Uniwersytetu Łódzkiego. Impreza odbyła się na placu pomiędzy Wydziałem Fizyki i Informatyki Stosowanej a Wydziałem Zarządzania UŁ.

15 czerwca 2012 r. na Wydziale Zarządzania UŁ odbyło się spotkanie z Państwowa Komisją Akredytacyjną. Na zebraniu nie zabrakło przedstawicieli kół naukowych, w tym zespołu "Uni-Logistics". Uczestnicy mieli możliwość wymiany poglądów.

Podsumowując dotychczasowa działalność Studenckiego Koła Naukowego Logistyki „Uni-Logistics”, można wyrazić przekonanie, że warto przyłączyć się do naszego zespołu i podjać studia na Wydziale Zarzadzania UŁ. 



\section{Bibliografia}

Armatys P., Infrastruktura transportowa w województwie łódzkim, Łódzki Ośrodek Badań Regionalnych, Urząd Statystyczny w Łodzi, Łódź 2009.

Bendkowski J., Kramarz M., Logistyka stosowana. Metody, techniki, analizy, cz. 2, Wyd. Politechniki Śląskiej, Gliwice 2006.

Bohatkiewicz J. (red.), Podręcznik dobrych praktyk wykonywania opracowań środowiskowych dla dróg krajowych, Biuro Ekspertyz i Projektów Budownictwa Komunikacyjnego EKKOM Sp. z o.o., Kraków 2007.

Cavill N., Davis A., Cycling and health: what's the evidence?, Cycling England, London 2007.

Chrzan T., Autostrady i materiały do ich budowy, Oficyna Wyd. Politechniki Wrocławskiej, Wrocław 2000.

Dekoster J., Schollaert U., Miasta rowerowe miastami przyszłości, Komisja Europejska, Luksemburg 2000.

Dora C., Phillips M., Transport, environment and health, WHO Regional Publications, European Series no. 89, Copenhagen 2000.

Dziadek S., Systemy transportowe ośrodków zurbanizowanych, PWN, Warszawa 1991.

Encyklopedia Popularna PWN, PWN, Warszawa 1996.

Gaca S., Suchorzewski W., Tracz M., Inżynieria ruchu drogowego. Teoria i praktyka, Wyd. Komunikacji i Łączności, Warszawa 2008.

Golińska P. (red.), Ekologiczne i ekonomiczne aspekty logistyki, Wyd. Politechniki Poznańskiej, Poznań 2009.

Gołembska E., Rola i zadania logistyki międzynarodowej w integracji przedsiębiorstw Unii Europejskiej, Wyd. Akademii Ekonomicznej w Poznaniu, Poznań 2005.

Groot H. P., Postaw na rower. Podręcznik projektowania przyjaznej dla rowerów infrastruktury, CROW/Polski Klub Ekologiczny, Kraków 1999.

Grzelakowski A., Matczak M., Przybyłowski A., Polityka transportowa Unii Europejskiej i jej implikacje dla systemów transportowych krajów członkowskich, Wyd. Akademii Morskiej w Gdyni, Gdynia 2008.

Kaczmarek M., Krycha A. (red.), Skuteczne zmniejszanie zatłoczenia miast, Wyd. i Drukarnia UNI-DRUK, Poznań 2009.

Karbowiak H., Podstawy infrastruktury transportu, Wyd. Wyższej Szkoły HumanistycznoEkonomicznej, Łódź 2009.

Kopata T., Dlaczego Europejski Dzień bez Samochodu?, Polski Klub Ekologiczny, Wrocław 2001.

Koziarski S., Transport w Europie, Wyd. Instytut Śląski, Opole 2005.

Kozłowski R. (red.), Strategiczne znaczenie dróg ekspresowych dla rozwoju Polski środkowo-wschodniej, wyd. 2 popr. i rozszerz., Wyd. Uniwersytetu Łódzkiego, Łódź 2010.

Kozłowski R., Sikorski A. (red.), Podstawowe zagadnienia współczesnej logistyki, Wolters Kluwer, Kraków 2009.

Koźlak A., Ekonomika transportu. Teoria i praktyka gospodarcza, Wyd. Uniwersytetu Gdańskiego, Gdańsk 2007.

Koźlak A., Kierunki zmian w planowaniu rozwoju transportu w miastach jako efekt dążenia do zrównoważonego rozwoju, „Transport Miejski i Regionalny” 2009, nr 7-8. 
Kupiec L. (red.), Gospodarka przestrzenna. Lokalizacja w gospodarce przestrzennej, t. 3, Wyd. Uniwersytetu w Białymstoku, Białystok 1999.

Kusiakiewicz T., Region jako ośrodek generujący popyt na przewozy, "Transport Miejski i Regionalny" 2009, nr 2.

Kwartnik-Pruc A., W pasie drogi, "Geodeta. Magazyn Geoinformacyjny" 2010, nr 2 (177).

Ligtermoet D., Continuous and integral: The cycling policies of Groningen and other European cities, Fietsberaad, Rotterdam 2006.

Markowski T., Zarządzanie rozwojem miast, Wyd. Naukowe PWN, Warszawa 1999.

Markowski T. (red.), Marketing terytorialny, Komitet Przestrzennego Zagospodarowania Kraju PAN, Warszawa 2006.

Matulewski M., Konecka S., Fajfer P., Wojciechowski A., Systemy logistyczne, Instytut Logistyki i Magazynowania, Poznań 2008.

Ministerie van Verkeer en Waterstaat, Cycling in the Netherlands, 2009.

Muszkieta R., Żukow W., Napierała M. i Saks E. (red.), Stan i rozwój regionalnego sportu i rekreacji, Ośrodek Rekreacji, Sportu i Edukacji w Poznaniu, Poznań 2010.

Neider J., Marciniak-Neider D., Transport multimodalny w Europie, Wyd. Uniwersytetu Gdańskiego, Gdańsk 2005.

Pawlicka Z., Przewozy pasażerów, Wyd. Komunikacji i Łączności, Warszawa 1979.

Przybyłowski A., Polityka spójności i polityka transportowa Unii Europejskiej w kontekście zrównoważonego rozwoju, "Transport i Komunikacja” 2009, nr 5.

Rakowera R., Kaleniewicz A., Rower na co dzień: komunikacja, rekreacja, ochrona środowiska, Stowarzyszenie „Sekcja Rowerzystów Miejskich”, Poznań 2001.

Roman Z., Międzynarodowe przewozy transportowe, Wyższa Szkoła Cła i Logistyki, Warszawa 2006.

Rydzykowski W., Wojewódzka-Król K., Transport, PWN, Warszawa 2005.

Santos Canals M., Pinaud A., Janneau T., Rasmussen O. R. (red.), Copenhagen: How bicycles can become an efficient means of public transportation, Roskilde University, Roskilde 2006.

Słownik wyrazów obcych, PWN, Warszawa 1980.

Starzyńska W., Rogalski W. J. (red.), Logistyka szansą rozwoju miasta i regionu na przykładzie ziemi piotrkowskiej, Naukowe Wydawnictwo Piotrkowskie, Piotrków Trybunalski 2008.

Szołtysek J., Car-pooling w koncepcji podróży pasażerskiej w miastach, "Logistyka" 2008, $\mathrm{nr} 4$.

Szołtysek J., Logistyczne aspekty zarządzania przepływami osób i ładunków w miastach, Wyd. Akademii Ekonomicznej w Katowicach, Katowice 2005.

Szołtysek J., Podstawy logistyki miejskiej, Wyd. Akademii Ekonomicznej w Katowicach, Katowice 2009.

Szymczak M., Logistyka miejska, Wyd. Akademii Ekonomicznej w Poznaniu, Poznań 2008.

Trembecka A., Jedna decyzja zamiast pięciu, "Geodeta. Magazyn Geoinformacyjny" 2011, nr 11 (198).

Twaróg J., Koszty logistyki przedsiębiorstw, Instytut Logistyki i Magazynowania, Poznań 2003.

Wesołowski J., Miasto w ruchu. Dobre praktyki w organizowaniu transportu miejskiego, Instytut Spraw Obywatelskich, Łódź 2008.

Wojalski M., 100 lat łódzkich tramwajów, Towarzystwo Opieki nad Zabytkami Oddział w Łodzi, Łódź 2002.

Wojewódzka-Król K. (red.), Rozwój infrastruktury transportu, Wyd. Uniwersytetu Gdańskiego, Gdańsk 1999. 
Wyszomirski O. (red.), Gospodarowanie w komunikacji miejskiej, Wyd. Uniwersytetu Gdańskiego, Gdańsk 2002.

Zalewski A., Europejskie tendencje użytkowania roweru na początku XXI w., materiały konferencyjne VII Konferencji Naukowo-Technicznej „Skuteczne zmniejszanie zatłoczenia miast", Uni-Druk, Poznań 2009.

Zielińska M., Zelent S., ADR 2009, Ośrodek Doradztwa i Doskonalenia Kadr, Gdańsk 2008.

\section{Inne źródła}

City of Copenhagen, Buildings and Construction Administration Roads and Parks Department, Cycle Policy 2002-2012, 2002.

City of Copenhagen, The Technical and Environmental Administration Traffic Department, Bicycle Account, 2008.

Decyzja o środowiskowych uwarunkowaniach dla realizowanej budowy drogi ekspresowej S-8, 8.01.2010.

Dyrektoriat Generalny Departamentu Energii i Transportu, Green Paper. Towards a new culture for urban mobility, 2007.

European Cyclist Federation, A sustainable future for transport: Towards and integrated, technology-led and user friendly system, 2009.

European Cyclist Federation, Odense - The National Cycle City of Denmark, Bicycle Research Report no. 157, 2004.

European Cyclist Federation, Transport Energy Efficiency: Response to the public consultation on the Action Plan for Energy Efficiency, 2007.

Film: Bicycle Culture 2.0 in Copenhagen: Look at This Amazing Bike-Friendly Urban Planning.

Fundacja FOR, PricewaterhouseCoopers, Wardyński i Wspólnicy, 4CFuture, Którędy droga? Raport o tym, jak odblokować inwestycje drogowe w Polsce, Warszawa 2009.

Gnoiński M., Wpływ układu sieci drogowej na sprawy obronności Polski i NATO, prezentacja multimedialna, Wydział Zarządzania Uniwersytetu Łódzkiego, Tomaszów Mazowiecki, 4.06.2008 r.

Komisja Wspólnot Europejskich, Biała Księga. Europejska polityka transportowa 2010: Czas na podjęcie decyzji, Szczecin 2002.

Narodowe Strategiczne Ramy Odniesienia 2007-2013, Wytyczne w zakresie postępowania w sprawie oddziaływania na środowisko dla przedsięwzięć wspóffinansowanych z krajowych lub regionalnych programów operacyjnych, Minister Rozwoju Regionalnego, Warszawa, 5 maja 2009.

Paturalska-Nowak E., Droga Ekspresowa S-8 - element strategicznego układu drogowego województwa łódzkiego, prezentacja multimedialna.

Pismo Senatora RP Andrzeja Owczarka do Ministra MON - dotyczy przebiegu drogi S-8 w okolicach lotniska wojskowego w Łasku, za: materiały udostępnione przez Biuro Senatorskie Senatora RP Andrzeja Owczarka, 2008.

Projekt założeń do projektu ustawy o zmianie ustawy o szczegółowych zasadach przygotowywania i realizacji inwestycji w zakresie dróg publicznych, Ministerstwo Infrastruktury, Warszawa, grudzień 2010.

Raport z konsultacji społecznych dla przedsięwzięcia p.n. budowa drogi ekspresowej S-14 - Zachodniej Obwodnicy Łodzi, Warszawa, grudzień 2008.

Rezolucja parlamentu europejskiego na rzecz mobilności w miastach, „Transport Miejski i Regionalny" 2009, nr 4. 
Rozporządzenie Rady Ministrów z dn. 20 października 2009 r. zmieniające rozporządzenie w sprawie sieci autostrad i dróg ekspresowych, Dz.U. z 2009 r., nr 187, poz. 1446.

Ustawa z dn. 7 lipca 1994 r. Prawo budowlane, Dz.U. z 2006 r., nr 156, poz. 1118.

Ustawa z dn. 27 października 1994 r. o autostradach płatnych oraz o Krajowym Funduszu Drogowym, Dz.U. z 2004 r., nr 256, poz. 2571.

Ustawa z dn. 20 czerwca 1997 r. Prawo o ruchu drogowym, Dz.U. z 1997 r., nr 98, poz. 602.

Ustawa z dn. 27 kwietnia 2001 r. Prawo ochrony środowiska, Dz.U. z 2001 r., nr 62, poz. 627.

Ustawa z dn. 10 kwietnia 2003 r. o szczególnych zasadach przygotowania i realizacji inwestycji w zakresie dróg publicznych, Dz.U. z 2008 r., nr 193, poz. 1194 z późn. zm.

Ustawa z dn. 29 stycznia 2004 r. Prawo zamówień publicznych, Dz.U. z 2007 r., nr 223, poz. 1655 oraz z 2008 r., nr 171, poz. 1058.

Ustawa z dn. 18 października 2006 r. o zmianie ustawy o szczególnych zasadach przygotowania i realizacji inwestycji w zakresie dróg krajowych oraz o zmianie niektórych innych ustaw, Dz.U. z 2006 r., nr 220, poz. 1601 z późn. zm.

Ustawa z dn. 3 października 2008 r. o udostępnianiu informacji o środowisku i jego ochronie oraz o ocenach oddziaływania na środowisko, Dz.U. z 2008 r., nr 199, poz. 1227 z późn. zm.

Uzasadnienie do decyzji o środowiskowych uwarunkowaniach dla realizowanej budowy drogi ekspresowej S-8, 2009.

Wojciechowski P., Konspekt - podstawy prawa rzeczowego, cz. II: Własność i inne prawa rzeczowe. Formy władania nieruchomościami, Uniwersytet Warszawski, 2011.

Zawiadomienie o wydaniu decyzji o zezwoleniu na realizację inwestycji drogowej z dn. 7 września $2011 \mathrm{r}$.

\section{Strony internetowe}

http://archiwum.polityka.pl

http://deutschland.de

http://dom.money.pl

http://ec.europa.eu

http://en.wikipedia.org

http://fakty.interia.pl

http://lodz.gazeta.pl

http://lodz.naszemiasto.pl

http://mfile.pl

http://mkmlodz.webd.pl

http://mosir.lodz.pl

http://pl.wikipedia.org

http://sumorok.pl

www.autobahnatlas-online.de

www.autobahn-online.de

www. berlin-life.com

www.bioz.pl

www.bmvb.de

www.carazoo.com www.civitas-initiative.org

www.cycling-embassy.dk

www.droginaeuro.pl

www.etracksonline.co.uk

www.euractiv.pl

www. fietsberaad.nl

www.gddkia.gov.pl

www.german-autobahn.eu

www.gettingaroundgermany.info/

index.shtml

www.iamsterdam.com

www.iicg.pl

www.infrastruktura.elamed.pl

www.invest.lodz.pl

www.kk.dk

www.mi.gov.pl

www.miastadlarowerow.pl

www.mos.gov.pl

www.mpk.lodz.pl 
www.odense.dk

www.portlodz.pl

www.rr.amu.edu.pl

www.serwisinwestora.pl

www.trail.com

www.transport-research.info/web

www.treehugger.com www.tur-info.pl

www.unece.org

www.uni-logistics.eu

www.uta.pl

www.visitdenmark.no

www.zdit.uml.lodz.pl

www.zm.org.pl 



\section{Spis tabel, rysunków, wykresów, map}

\section{Tabele}

Tabela 1. Wykaz atrakcji turystycznych analizowanych powiatów $\ldots \ldots \ldots \ldots \ldots \ldots \ldots \ldots \ldots$

Tabela 2. Struktura wykorzystywanych przez turystów środków transportu, którymi przyjechali do atrakcji turystycznych w województwie łódzkim (w \%) .....11

Tabela 3. Opinia turystów na temat dojazdu do miejscowości oraz transportu

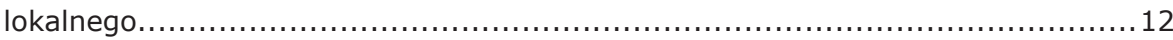

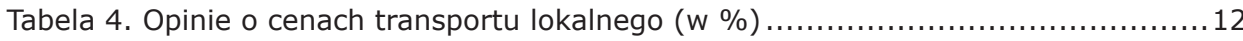

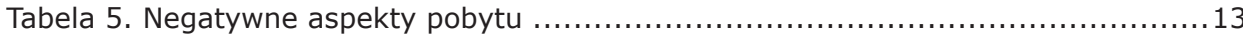

Tabela 6. Ograniczenia prędkości narzucane niektórym pojazdom........................23

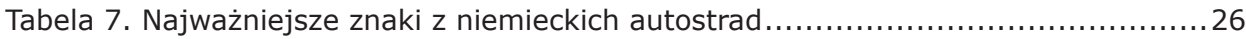

Tabela 8. Znaczenie niektórych znaków elektronicznych ................................ 29

Tabela 9. Węzły autostradowe A 10, w których ma miejsce krzyżowanie się

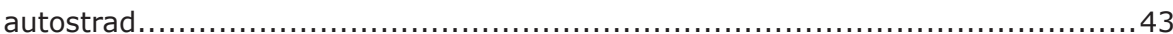

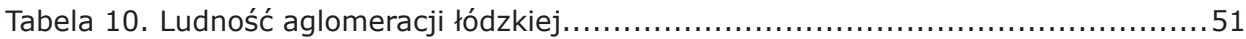

Tabela 11. Znaki drogowe uzupełniające, kierujące tranzyt samochodowy ................54

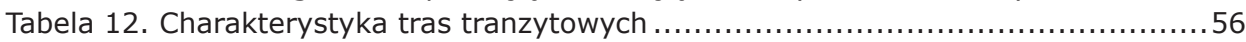

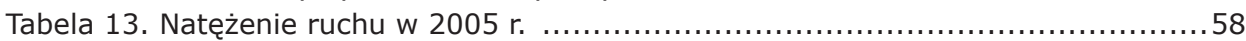

Tabela 14. Drogi ekspresowe o statusie „Priorytet na Euro 2012 " ......................64

Tabela 15. Elementy systemu obwodnic wokół aglomeracji łódzkiej ......................66

Tabela 16. Wady i zalety poszczególnych środków komunikacji miejskiej ..................96

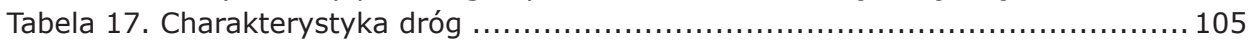

Tabela 18. Propozycja ilości miejsc rowerowych przypadających na każdą

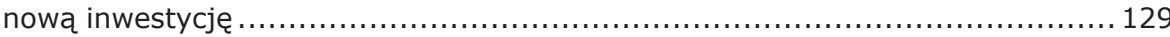

Tabela 19. Zestawienie odcinków S8 w województwie łódzkim z uwzględnieniem węzłów i obiektów infrastrukturalnych ........................... 173

\section{Rysunki}

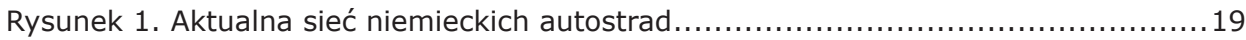

Rysunek 2. Aktualny system numeracji autostrad w Niemczech........................ 20

Rysunek 3. Znak pozwalający na jazdę po pasie bezpieczeństwa podczas

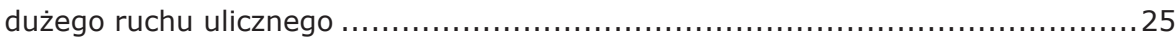

Rysunek 4. Znak informujacy o nakazie zmiany pasa ruchu np. w sytuacji

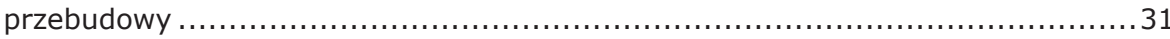

Rysunek 5. Mapa autostrad oraz planowanych autostrad na obszarze aglo-

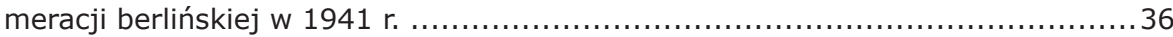

Rysunek 6. Schemat aglomeracji monocentrycznej..................................... 50

Rysunek 7. Aglomeracja łódzka - aglomeracją monocentryczną .......................5 50

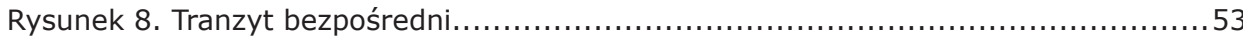

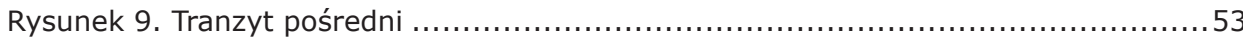




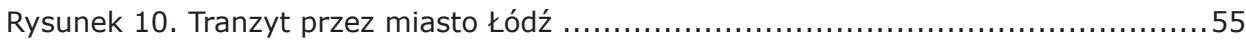

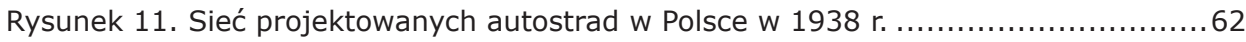

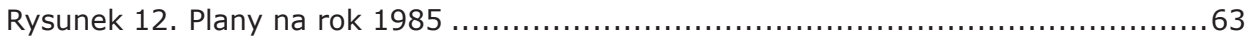

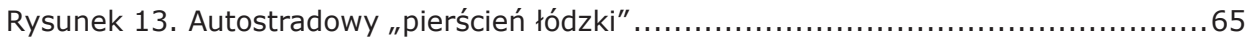

Rysunek 14. Wagon Herbrand VNB125-15 na ul. Dzielnej (obecnie ul. Naruto-

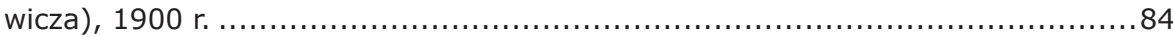

Rysunek 15. Podróż miejska jako łańcuch przemieszczania............................. 120

Rysunek 16. Wpływ rozwoju infrastruktury transportu na rozwój gospodarczy.......... 146

Rysunek 17. Ogólne determinanty wizerunku miasta .................................. 149

Rysunek 18. Elementy węzła drogowego ............................................... 175

\section{Wykresy}

Wykres 1. Udział poszczególnych środków transportu w Holandii ....................... 133

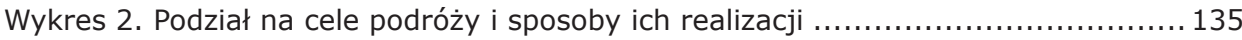

\section{Mapy}

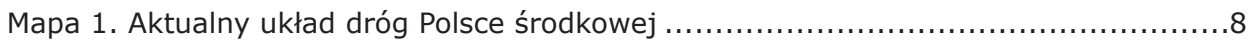

Mapa 2. Znowelizowana sieć TEN-T w Polsce środkowej ............................... 15

Mapa 3. Badania natężenia ruchu drogowego - stan na 2005 r. ......................... 160

Mapa 4. Liczba pojazdów samochodowych w regionie łódzkim - stan na 2010 r. ...... 161 